\title{
Paleontology and Stratigraphy of the Rabbit Hill Limestone and Lone Mountain Dolomite of Central Nevada
}

GEOLOGICAL SU RVEY PROFESSIONAL PAPER 808

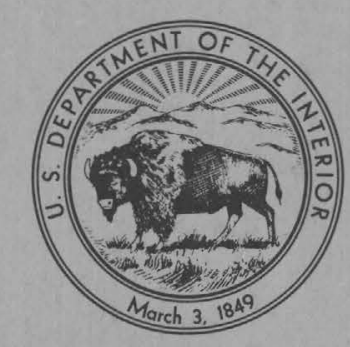





\section{Paleontology and Stratigraphy of the Rabbit Hill Limestone and Lone Mountain Dolomite of Central Nevada}

By C. W. MERRIAM

GEOLOGICAL SURVEY PROFESSIONAL PAPER 808 A comparative study of fossils from contrasting carbonate facies near the Silurian-Devonian boundary, and a review of stratigraphic relations

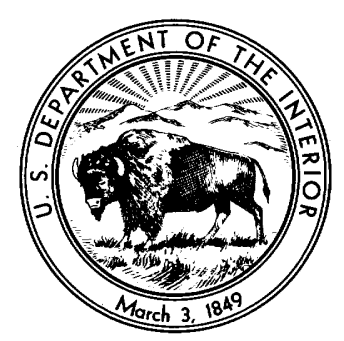




\section{UNITED STATES DEPARTMENT OF THE INTERIOR \\ ROGERS C. B. MORTON, Secretary}

\section{GEOLOGICAL SURVEY}

V. E. McKelvey, Director

Library of Congress catalog-card No. 73-600125

For sale by the Superintendent of Documents, U.S. Government Printing Office

Washington, D.C. 20402 - Price $\$ 1.75$

Stock Number 2401-02379 


\section{CONTENTS}

Abstract

Introduction

Purpose and scope of investigation

Acknowledgments

History of investigation

Methods

Silurian and Early Devonian depositional belts of

the Great Basin

Areal distribution and stratigraphy of the

Rabbit Hill Limestone

Rabbit Hill, northern Monitor Range

Dobbin Summit, Monitor Range

Northern Toquima Range

McClusky Peak area, Simpson Park Range

Coal Canyon, northern Simpson Park Range

Cortez Mountains and Tuscarora Mountains

Beacon Peak Dolomite, Sulphur Spring Range

Age and correlation of the Rabbit Hill Limestone

Lone Mountain Dolomite

Lone Mountain Dolomite, Lone Mountain

Lone Mountain Dolomite, southern Mahogany Hills .

Lone Mountain Dolomite, southern

Fish Creek Range .

Lone Mountain Dolomite, Sulphur Spring Range ..........

Age and correlation of the Lone Mountain Dolomite ..........

Conclusions regarding relation of Rabbit Hill Limestone

to Lone Mountain Dolomite

Great Basin Silurian and Devonian coral zones .

Systematic and descriptive paleontology

Fossils of the Rabbit Hill Limestone and Beacon Peak

Dolomite Member of the Nevada Formation

Order Tabulata Edwards and Haime

Family Favositidae Dana

Genus Favosites Lamarck.

Favosites cf. $F$. helderbergiae Hall .

Genus Striatopora Hall

Striatopora cf. S. gwenensis

Amsden

Genus Pleurodictyum Goldfuss ................. Pleurodictyum nevadensis $\mathrm{n} . \mathrm{sp}$...... Pleudorictyum dunbari $\mathrm{n}$. sp

Order Rugosa Edwards and Haime

Family Laccophyllidae Grabau

Genus Syringaxon Lindström

Syringaxon foerstei $\mathrm{n}$. sp.

Family Streptelasmatidae Nicholson .

Genus Siphonophrentis O'Connell

Siphonophrentis sp. B

Family Endophyllidae Torley

Australophyllum Stumm ............. Australophyllum landerensis n. sp .. Australophyllum stevensi n. sp ........ Australophyllum sp. v .....................

Family Disphyllidae Hill Genus Billingsastraea Grabau
Page

1
Fossils of the Rabbit Hill Limestone and Beacon Peak Dolomite Member of the Nevada Formation-Con. Order Rugosa Edwards and Haime-Continued

Family Disphyllidae Hill-Continued Genus Billingsastraea Grabau-Con. Billingsastraea sp. m

Phylum Brachiopoda

Order Orthida Schuchert and Cooper ................... 25

Family Rhipidomellidae Schuchert ................ $\quad 25$

Genus Rhipidomella Oehlert ................... 25

Rhipidomella rossi $\mathrm{n} . \mathrm{sp}$.................. 25

Family Dalmanellidae Schuchert ................. 26

Genus Levenea Schuchert and Cooper .... 26 Levenea subcarinata subsp antelopensis n. subsp _................. 26

Family Orthidae Woodward ......................... 27

Genus Orthostrophia Hall ....................... 27

Orthostrophia strophomenoides subsp. newberryi n. subsp ............ 27

Order Strophomenida Öpik ................................. 27

Family Stropheodontidae Caster .................. 27

Genus Leptostrophia Hall and Clarke .... 27

Leptostrophia sp. cf. L. becki

tennesseensis Dunbar ................. 27

Genus Pholidostrophia Hall and Clarke .. 28

(?) Pholidostrophia sp. R ............... 28

Genus Strophonella Hall ....................... 28

Strophonella cf. S. punctulifera (Conrad)

Family Leptaenidae Hall and Clarke

Genus Leptaena Dalman ........................ 28

Leptaena fremonti $\mathrm{n} . \mathrm{sp}$.................. 28

Family Schuchertellidae Williams ............... 29

Genus Schuchertella Girty .................... 29

Schuchertella cf. S. haraganensis

Amsden

Order Pentamerida Schuchert and Cooper .......... 29

Family Parastrophinidae Ulrich and Cooper 29

Genus Anastrophia Hall ........................ 29

Anastrophia cf. A. verneuili (Hall) .. 29

Order Rhynchonellida Kuhn ................................. 29

Family Uncinulidae Rzhonsnitskaya ........... 29

Genus Plethorhyncha Hall and Clarke .... 29

Plethorhyncha andersoni $\mathrm{n} . \mathrm{sp}$........ 29

Order Spiriferida Waagen ...................................... 30

Family Meristellidae Waagen ........................ 30

Genus Meristella Hall ............................ $\quad 30$

Meristella martini $\mathrm{n} . \mathrm{sp}$.................. 30

Family Ambocoeliidae George ..................... 30

Ambocoelia sp. a ................................ $\quad 30$

Family Leptocoeliidae Boucot and Gill ....... 31

Genus Leptocoelia Hall .......................... 31

Leptocoelia occidentalis n. sp ......... 31

Family Retziidae Waagen ............................ 31

Genus Trematospira Hall ........................ 31 
Fossils of the Rabbit Hill Limestone and Beacon Peak Dolomite Member of the Nevada Formation-Con.

Phylum Brachiopoda-Continued

Order Spiriferida Waagen-Continued

Family Retziidae Waagen-Continued

Genus Trematospira Hall-Continued

Trematospira mcbridei $\mathrm{n}$. sp

Family Delthyrididae Waagen

Genus Kozlowskiellina Boucot ... Kozlowskiellina nolani $\mathrm{n} . \mathrm{sp}$............ 32

Genus Howellella Kozlowski ................. 33 Howellella cycloptera (Hall) subsp. monitorensis n. subsp ....... 33

Genus Acrospirifer Helmbrecht and Wedekind Acrospirifer kleinhampli n. sp $\quad$...... 34

Family Costispiriferidae Termier and

Termier

Genus Costispirifer Cooper

Costispirifer arenosus (Conrad) subsp. dobbinensis n. subsp

Tentaculitids and conulariids of the Rabbit

Hill Limestone

Order Conulariida Miller and Gurley

Family Conulariidae Walcott

Genus Conularia sp. cf. C.

huntiana Hall

Mollusca of the Rabbit Hill Limestone

Family Platyceratidae Hall

Genus Platyceras Conrad

Platyceras sp. a

Platyceras sp. b

Platyceras (Orthonychia) sp. c .....

Trilobites of the Rabbit Hill

Family Odontopleuridae Burmeister

Genus Leonaspis Richter and Richter 36 Leonaspis cf. L. tuberculatus (Hall) 36

Genus Miraspis Richter and Richter ..... 37 (?) Miraspis sp

Family Phacopidae Hawle and Corda

. 37

Genus Phacops Emmrich Phacops sp. A, cf. P. logani Hall ...... 37 (?) Phacops sp. B, cf. P. canadensis Stumm
Page

Fossils of the Rabbit Hill Limestone and Beacon Peak Dolomite Member of the Nevada Formation-Con.

Trilobites of the Rabbit Hill-Continued

Family Dalmanitidae Vogdes

Fossils of the Lone Mountain Dolomite

Order Rugosa Edwards and Haime...

Family Tryplasmatidae Etheridge

Genus Tryplasma Lonsdale

Tryplasma sp. f

Family Kyphophyllidae Wedekind Genus Entelophyllum Wedekind Entelophyllum engelmanni n. sp .... Entelophyllum engelmanni subsp. b Entelophyllum eurekaensis n. sp ....

Phylum Brachiopoda

Order Orthida Schuchert and Cooper

Family Enteletidae Waagen

Genus Salopina Boucot Salopina sp. f

Order Rhynchonellida Kuhn

Family Camarotoechiidae Schuchert and Levene Genus Camarotoechia Hall and Clarke .. 40 Camarotoechia pahranagatensis Waite Camarotoechia sp. b Camarotoechia sp. f

Order Spiriferida Waagen

Family Meristellidae Waagen

Genus Hyattidina Schuchert ?Hyattidina $\mathrm{sp} . \mathrm{f}$

Genus Hindella Davidson Hindella sp. a

Family Atrypidae Gill

Genus Atrypa Dalman Atrypa sp. f

Family Delthyrididae Waagen

Genus Howellella Kozlowski Howellella pauciplicata Waite ....... 41 Howellella smithi Waite

Locality register

Selected bibliography

37 Index
Page 37 37 37

\section{ILLUSTRATIONS \\ [Plates follow index]}

Plate 1. Striatopora, Pleurodictyum, Favosites, and Platyceras.

2. Syringaxon, (?) Phacops, (?) Miraspis, Leonaspis, and Conularia.

3. Leptostrophia, Orthostrophia, (?) Pholidostrophia, Stropheodonta, Strophonella, Schuchertella, and Leptaena.

4. Levenea and Rhipidomella.

5. Leptocoelia and Anastrophia.

6. Plethorhyncha, Trematospira, and Kozlowskiellina.

7. Costispirifer, Acrospirifer, Howellella, Meristella, and Ambocoelia.

8. Siphonophrentis, Schuchertella, Leptostrophia, Orthostrophia, Howellella, Rhipidomella, and Phacops.

9. Billingsastraea and Australophyllum.

10. Entelophyllum.

11. Atrypa, Camarotoechia, Salopina, Tryplasma, Entelophyllum, pycnostylid coral, and Pycnostylus.

12. Howellella, ?Hyattidina, and Hindella. 
FIGURE 1. Index map of part of the Great Basin showing location of Rabbit Hill Limestone and Lone Mountain

Page

Dolomite fossils and approximate limits of Late Silurian-Early Devonian depositional facies belts
2.... Photograph showing view northwest across Copenhagen Canyon from Martin Ridge, showing Rabbit Hill and overthrust Ordovician Antelope Valley limestone cliffs

3. Photograph showing south side of Rabbit Hill, showing minor drag folds in west-dipping Rabbit Hill Limestone of the type section

4. Correlation diagram showing stratigraphic relations of the Rabbit Hill Limestone and inferred equivalence of Lone Mountain Dolomite to the Silurian Roberts Mountains Limestone

5. Diagram illustrating history and present usage of the stratigraphic name Lone Mountain Dolomite 5

6. Photograph showing south side of Lone Mountain, showing east-dipping stratigraphic section upward from Ordovician Antelope Valley Limestone to Devonian Nevada Formation

7. Correlation diagram showing stratigraphic relations of the Lone Mountain Dolomite and its equivalence

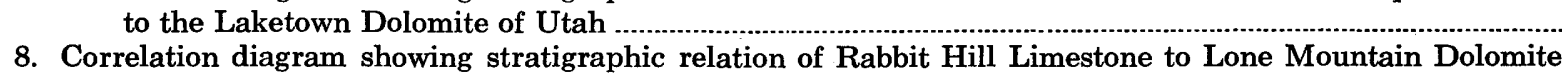

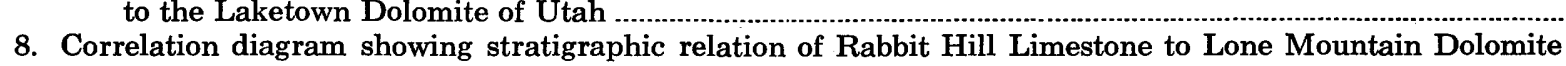
as interpreted -

\section{TABLES}

TABLE 1. Characteristic fossils of the Rabbit Hill Limestone and Beacon Peak Dolomite Member of the Nevada Formation 10

2. Characteristic fossils of the upper Lone Mountain-Laketown biofacies 


\title{
PALEONTOLOGY AND STRATIGRAPHY OF THE RABBIT HILL LIMESTONE AND LONE MOUNTAIN DOLOMITE OF CENTRAL NEVADA
}

\author{
By C. W. MERRIAM
}

\begin{abstract}
Lateral facies changes from diagenetic dolomite on the east to limestone on the west greatly complicate stratigraphy and paleontology of the Silurian and Devonian Systems in the central Great Basin. Occupying the Silurian interval on the east, the Lone Mountain Dolomite is nearly barren of specifically identifiable fossils in its type section, but in the Fish Creek Range and other parts of its type area it has recently been found to contain well-preserved fossils. In the west-central Great Basin, the highly fossiliferous Rabbit Hill Limestone of Helderberg (Early Devonian) age overlies Silurian limestone and calcareous graptolitic shale of the Monitor-Simpson Park belt, in which no Lone Mountain dolomite has been discovered.

The Rabbit Hill Limestone lithofacies is unknown to the east in the Antelope-Roberts Mountains belt, in which Lone Mountain Dolomite occurs; however, Rabbit Hill fossils are present locally in dolomite and dolomitic limestone of the Beacon Peak Dolomite Member of the Nevada Formation. Southeast of Eureka, Nev., in its type area, this member disconformably overlies the Lone Mountian Dolomite, being the lowermost member in that section of the Devonian Nevada Formation. In the Sulphur Spring Range, fossiliferous Beacon Peak underlies Oriskany-age Nevada Formation containing Costispirifer arenosus.
\end{abstract}

The Rabbit Hill fauna is far more diverse taxonomically than the Lone Mountain Dolomite fauna. Its diagnostic fossils include the corals Pleurodictyum nevadensis, Pleurodictyum dunbari, and Syringaxon foerstei and the brachiopods Levenea subcarinata subsp. antelopensis, Leptocoelia occidentalis, Kozlowskiellina nolani, and Howellella cycloptera subsp. monitorensis. Upper beds of the Rabbit Hill Limestone at Dobbin Summit, Monitor Range, contain the large spirifers Costispirifer arenosus subsp. dobbinensis and Acrospirifer kleinhampli, forms that foreshadow the Oriskany (Siegenian) age faunas in the lower part of the Nevada Formation.

Species of Pleurodictyum, Levenea, Howellella, and Anastrophia, among others, indicate correlation of the Rabbit Hill Limestone and Beacon Peak Dolomite with Helderbergian rocks of New York and Tennessee. Whereas the westerly facies Rabbit Hill Limestone was initially regarded as a possible time-stratigraphic equivallent of the easterly Lone Mountain Dolomite facies, paleontologic and stratigraphic evidence fails to support this view. A remote possibility of a very early Devonian horizon in topmost unfossiliferous beds of the Lone Mountain is not entirely ruled out.

In areas recently mapped geologically within a few miles of Lone Mountain, silicified corals and brachiopods characterize dark-gray carbonaceous dolomite lenses in the upper part of the Lone Mountain Dolomite. Of these Lone Mountain fossils, the most diagnostic are species of the rugose coral Entelophyllum and the brachiopod Howellella. The small spiriferoids Howellella pauciplicata and Howellella smithi indicate a correlation with the uppermost part of the Silurian Laketown Dolomite in the Confusion Range, Utah. Entelophyllum is unknown later than the Silurian.

\section{INTRODUCTION}

The stratigraphy and paleontology of the Silurian and Devonian Systems in the central Great Basin is complicated by lateral facies changes from diagenetic dolomite on the east to limestone on the west. In the Silurian, the principal direction of this change is northwesterly, limestones on the west and northwest occupying stratigraphic positions in which dolomite comes to prevail in the opposite directions. For example, at Lone Mountain and in the Eureka mining district the Silurian is entirely dolomite, whereas to the northwest in the Roberts Mountains and adjacent parts of the Simpson Park Range it is largely limestone. Biofacies changes accompanying westerly to northwesterly disappearance of the Silurian diagenetic dolomite are commensurate with enclosing lithofacies differences. Faunal disparity explainable by facies appears to be of such magnitude as to eliminate or render uncertain a direct paleontologic correlation of these two contrasting Silurian carbonate facies.

In the central Great Basin, the Silurian limestones and calcareous shales are more abundantly fossiliferous than the easterly dolomites. Until recently, in fact, identifiable fossils were unknown in the Lone Mountain Dolomite in its type area, which includes Lone Mountain and mountain ranges within and adjacent to the Eureka mining district. Whereas the Silurian age of much of the limestone and shale has now been fixed paleontologically with some confidence, dating heretofore of the dolomite facies has remained inferential because of the scarcity of determinable fossils. 
The name Roberts Mountains Formation (Merriam, 1940, p. 11) was applied to the Silurian limestones and calcareous shales of the westerly belt in this part of the Great Basin. Limestones originally included as the uppermost part of the Roberts Mountains Formation in the Monitor Range (Merriam and Anderson, 1942, p. 1687) were found, in 1947, to be of probable Helderberg (Early Devonian) age. In 1963 (Merriam, 1963, p. 42) these lithologically distinctive and fossil-rich upper limestones were described as a separate formation, the Rabbit Hill Limestone. Rabbit Hill fossils described here include those of the original list from the Monitor Range type area (Merriam, 1963, p. 43).

\section{PURPOSE AND SCOPE OF INVESTIGATION}

The main objectives of this paleontologic report are to describe and illustrate stratigraphically significant megafossils from the Rabbit Hill Limestone in its type area in the Monitor Range and the Lone Mountain Dolomite in its type area in the vicinity of the Eureka mining district, Nevada. Collections from the Rabbit Hill in its type area are supplemented by material from outlying areas in the Monitor Range, Toquima Range, Simpson Park Range, Cortez Mountains, and the Tuscarora Mountains, where the Rabbit Hill fauna was discovered during the course of geologic mapping programs. Especially significant stratigraphically are Rabbit Hill fossils found in the lowermost part of the Nevada Formation of the Sulphur Spring Range during the Kobeh Valley program. Conclusions regarding relative geologic ages of the Rabbit Hill Limestone and the Lone Mountain Dolomite, which as lithologic entities do not occur in the same stratigraphic section, are based upon paleontologic comparisons made in conjunction with studies of the structure, stratigraphy, and areal geology of their outcrop belts. Details of the stratigraphy of both units have been dealt with in other contributions (Merriam, 1940, 1963, 1973a, 1973b; Nolan and others, 1956).

This comprehensive study of the previously undescribed Rabbit Hill and Lone Mountain faunas is intended to amplify and support stratigraphic-paleontologic conclusions of monographic studies of rugose corals in all Silurian and Devonian formations of the central Great Basin (Merriam, 1973a, 1973b, 1973c). Proposed zonation of Great Basin Silurian and Devonian rocks by means of Rugosa (Merriam, 1973a, 1973b) takes into consideration the stratigraphic occurrences of associated fossil groups, especially the brachiopods. Several well-represented phyla remain to be studied by specialists.

Conodont and graptolite investigations bearing upon the complex interrelations of the Lone Mountain, Rabbit Hill, and Roberts Mountains Formations have, in recent years, led to conflicting age results, conclusions seemingly out of phase with those founded upon coral and brachiopod research. A first step toward adjustment of this confusion is the systematic collection and study of conodont material and graptolites, from beds and sequences that also yield diagnostic corals, brachiopods, and other megafossils. Encouragement of such unifying field and laboratory procedures is an ancillary objective of this investigation.

Conodonts are abundant in the Rabbit Hill Limestone in its type area and are briefly considered here (Huddle, J. W., written communs., 1969, 1970). Monograptid graptolites are reported from the type section (W. B. N. Berry, oral commun., 1971), although none were obtained during this study. In contrast, the Lone Mountain Dolomite in its type area has yielded neither conodonts nor graptolites during the course of this study. Accordingly, a searching review is called for of the somewhat circuitous and inductive stratigraphic speculations of conodont researchers whose reasoning leads to Devonian rather than Silurian age for the greater part of the Lone Mountain Dolomite (Clark and Ethington, 1966; Johnson, 1970).

\section{ACKNOWLEDGMENTS}

Reconnaissance geologic mapping of counties in the central Great Basin by geologists of the U.S. Geological Survey has extended known areal distribution of the Rabbit Hill Limestone and led to discovery of richly fossiliferous exposures of this formation. Among contributors to the map areas involved are F. J. Kleinhampl, northern Nye County, Nev.; R. J. Roberts and R. E. Lehner, northern Eureka County, Nev.; and E. H. McKee and J. H. Stewart, Lander County, Nev. L. D. Cress, U.S. Geological Survey, discovered the northernmost known Rabbit Hill exposures at Maggie Creek during geologic mapping in the vicinity of the Carlin, Nev., gold mine. Geologic mapping by E. H. McKee in the Wildcat Peak and Dianas Punch Bowl quadrangles, Toquima Range, Nev., led to the finding of Rabbit Hill fossils and has aided in clarifying the stratigraphic relations of the Rabbit Hill Limestone to Silurian strata correlative with the Roberts Mountains Limestone.

Correlation and age determination of the Lone Mountain Dolomite were facilitated by mapping, stratigraphic study, and fossil collecting by R. K. Hose, U.S. Geological Survey, in the Silurian Laketown Dolomite of the Confusion Range, Utah.

Glacial cobbles collected by F. K. Miller, U.S. Geological Survey, in Stevens County, northeast Washington, yielded silicified fossils suggestive of the Rabbit Hill fauna.

A fossil collection from the Cortez Mountains, Nev., made by A. J. Boucot of Oregon State University has 
aided in establishing the relation of the Rabbit Hill to the Wenban Limestone. C. H. Stevens, San Jose State College, contributed a well-preserved colonial rugose coral from the Sunday Canyon Formation of the Inyo Mountains, Calif.

J. W. Huddle, U.S. Geological Survey, prepared reports on Rabbit Hill Limestone conodonts, and Jean M. Berdan, of the Survey, identified ostracods from the same formation.

The writer gratefully acknowledges the critical reading of the manuscript by G. Arthur Cooper, of the Smithsonian Institution.

\section{HISTORY OF INVESTIGATION}

The "Lone Mountain Limestone" in its type area, as described by Hague (1892, p. 57-62), included beds now differentiated as Late Ordovician and Silurian. In 1892 the Ordovician or "Lower Silurian" had not been fully adopted by the U.S. Geological Survey as a system. Hague's (1892, p. 324-325) initial "Upper Silurian" assignment of the higher part of the Lone Mountain was inferential at best and predicated upon the position of these dolomites beneath strata of established Devonian age (Walcott, 1884, p. 4, 99-211).

In redefining the "Lone Mountain Formation" at Lone Mountain in 1940, Merriam removed the separately mappable Late Ordovician dolomite as a lateral equivalent of the Hanson Creek Limestone. Merriam also concluded that an overlying medium-gray dolomite of Hague's original "Lone Mountain Limestone" could reasonably be interpreted at that time as a southerly dolomite equivalent of the Silurian Roberts Mountains Limestone exposed 20 miles to the northwest. Still undated by fossils, the restricted "Lone Mountain Formation" of Merriam (1940,p. 13) was viewed as resting conformably upon the Silurian Roberts Mountains Limestone in the Roberts Mountains, and upon its inferred dolomitic counterpart at Lone Mountain. A prominent chert marker unit occurs at the base of the Silurian Roberts Mountains Limestone of the type area and occupies the same position below the Silurian dolomite at Lone Mountain. The chert unit has been referred to as the Silurian basal chert, because in subsequent years it was discovered at many widely scattered localities in the Great Basin, where it lies upon Late Ordovician strata of Hanson Creek Richmondian age. In some areas where thick dolomites above the chert marker have yielded no fossils, the higher part of this dolomite sequence probably includes beds of Early or even Middle Devonian age.

Reconnaissance geologic mapping and stratigraphic investigation in the northern Monitor Range during the 1930's (Merriam and Anderson, 1942, p. 1687) disclosed a Silurian graptolitic sequence comprising cal- careous shale and platy limestone resting upon the Silurian basal chert; these graptolitic beds are in the area overlain by richly fossiliferous limestones later mapped separately and designated as Rabbit Hill Limestone. In 1942, all of these beds, including the Rabbit Hill, were considered part of the Silurian Roberts Mountains Limestone. In accordance with Merriam's 1940 redefinition, the entire sequence appeared, therefore, to be older than the restricted Lone Mountain Formation at Lone Mountain. Absence of dolomites in this westerly Monitor Range column could be explained by absence in the west of beds representing their timestratigraphic interval; more likely, the interval above the Silurian basal chert recorded by dolomite at Lone Mountain was occupied in the Monitor Range by limestone and calcareous shale facies of deposition.

Paleontologic evaluation of the Rabbit Hill Limestone by Merriam in 1947 led to the conclusion that it was of Helderbergian (Early Devonian) age rather than Silurian, encouraging search elsewhere for equivalent Devonian strata at the top of the Roberts Mountains Limestone. In the light of this disclosure and the theory of lithofacies change from easterly dolomite to limestone in the west, it now appeared not improbable that the Lone Mountain Formation as restricted by Merriam in 1940 might also be of Devonian age.

Progress toward eventual clarification of the Lone Mountain-Rabbit Hill age relation was made after 1957 because of continued geologic mapping and stratigraphic work under the Kobeh Valley project of T. B. Nolan and Merriam. Discovery of Rabbit Hill fossils in lowermost beds of the Nevada Formation and the finding of Silurian faunas containing Entelophyllum and Howellella in the upper 500 feet of the Lone Mountain Dolomite in its type area convincingly suggested that the Rabbit Hill Limestone was actually younger than the restricted Lone Mountain. Beds containing the lowest Nevada Rabbit Hill fossils are assigned to the Beacon Peak Dolomite Member of the Nevada Formation which, in the Eureka mining district, rests disconformably upon the Lone Mountain Dolomite as mapped in that area (Nolan and others, 1956, p. 42).

Restudy of the thick dolomite sequence that overlies the type section of the Roberts Mountains Limestone at Roberts Creek Mountain gave no direct fossil evidence of its age. These dolomites underlie the Nevada Formation, and in the absence of fossils were assigned in 1940 by Merriam to the Lone Mountain Formation. In the present state of knowledge of these rocks, it appears not unlikely that the upper part of the dolomite may represent the Beacon Peak Dolomite Member of the Nevada Formation, whereas the lower part is conceivably a northwestward-extending tongue of the Lone Mountain Dolomite. The underlying highest beds 
of the Roberts Mountains Limestone contain the fauna of Silurian coral zone D. The fauna of Silurian coral zone $\mathrm{E}$ would be expected in the overlying dolomite, conceivably followed upward by an Early Devonian fauna of the Rabbit Hill Limestone within the uppermost dolomite.

A forward step in unraveling the Late Silurian-Early Devonian stratigraphic relation in the central Great Basin was made in 1960 by Winterer and Murphy, who found the Early Devonian Rabbit Hill Limestone resting conformably upon the Silurian Roberts Mountains Limestone in the northern Simpson Park Range. At Coal Canyon, 10 miles northwest of Roberts Creek Mountain, the uppermost Roberts Mountains Limestone contains Late Silurian coral zone E. No dolomite is present in this Simpson Park section, which represents a westerly limestone and calcareous shale facies of the Monitor-Simpson Park belt.

Description of Silurian brachiopods from the Laketown Dolomite (Waite, 1956; Johnson and Reso, 1964) of the eastern Great Basin has facilitated study of the Lone Mountain Dolomite faunas, which are much more closely related to faunas of the Laketown than to faunas of the Silurian limestone facies. Detailed geologic mapping and stratigraphic study of the Laketown Dolomite in the Confusion Range of western Utah by R. K. Hose (written communs., 1954-1964) provided the fossil collections and other data employed here.

\section{METHODS}

Fossils described here were for the greater part systematically collected in conjunction with geologic mapping and structural study in a region of intense deformation. Lateral facies change, thrusting, and pervasive normal faulting are features that require cooperative effort of the geologist and the paleontologist in the piecing together of composite reference columns ever subject to critical revision. As a case in point, discovery of Rabbit Hill fossils in the basal Nevada Forfation above the Lone Mountain failed to support the conclusion drawn from initial mapping of the Rabbit Hill Limestone and the Lone Mountain Dolomite, that these contrasting carbonate facies occupied separate depositional belts and were mutually exclusive and possibly correlative laterally in a time-stratigraphic sense. Difficulty in continuous section measurement is well illustrated in the Rabbit Hill Limestone in its type area, where incompetent strata are folded and dragged beneath a major overthrust; only a few hundred feet of section is measurable at any one exposure. Regarding true vertical order of the Silurian faunas, in particular, uncertainties remain to be resolved by detailed geologic mapping and interpretation of geologic structure and lateral facies change.
These paleontologic studies place emphasis upon the rugose corals. Systematic and descriptive research on these abundant and commonly well-preserved fossils makes possible their meaningful use in age determination, geologic correlation, and problems of depositional facies. The Rugosa have been used in conjunction with brachiopods as a basis for paleontologic zonation of Silurian and Devonian rocks of the Great Basin (Merriam, 1973a, 1973b). Because fossils are more abundant and better preserved in the Silurian limestone facies than in the dolomites, the rugose corals of these facies have been more thoroughly investigated and are better understood. Because of the biofacies differences, correlation of Silurian faunal horizons across the inferred lithofacies boundaries will doubtless remain quite speculative.

This report deals mainly with silicified fossils prepared by acid treatment. In the Rabbit Hill bioclastic limestones, silicification was strangely selective; the corals and brachiopods were replaced to a much greater extent that associated Mollusca, Echinodermata, and other organic groups, which evidently were chemically less amenable to silica replacement. All identifiable fossils from the Lone Mountain Dolomite are silicified. Although the fossils from dolomite are well preserved externally, the internal structures were commonly destroyed in part by recrystallization.

\section{SILURIAN AND EARLY DEVONIAN DEPOSITIONAL BELTS OF THE GREAT BASIN}

Silurian marine rocks in the southwestern part of the Cordilleran geosyncline (fig. 1) are distributed in three contrasting lithologic belts (Merriam, 1973a): (1) A western graywacke belt of the Pacific Border, (2) an intermediate limestone belt, and (3) an eastern dolomite belt. The intermediate limestone belt traverses the west-central Great Basin in a north to northeasterly direction between the graywacke on the west and the very extensive dolomite belt on the east. Passing from one to another of these belts, faunas of about the same age show biofacies differences that seem to be related in part to change of depositional environment as well as to features of paleogeography and faunal dispersal. Similar facies belts are recognizable in the Devonian.

The Silurian Roberts Mountains Limestone and overlying Rabbit Hill Limestone occupy the intermediate limestone belt; the Lone Mountain Dolomite lies in the eastern dolomite belt. A diagenetic dolomite, the Lone Mountain, occurs at the west border of a very extensive dolomite sheet which, as the Laketown Dolomite, includes all known Silurian strata of the eastcentral and eastern Great Basin. The graywacke or Pacific Border belt is preponderantly graywacke, volcanic rocks, and conglomerate with subordinate lime- 


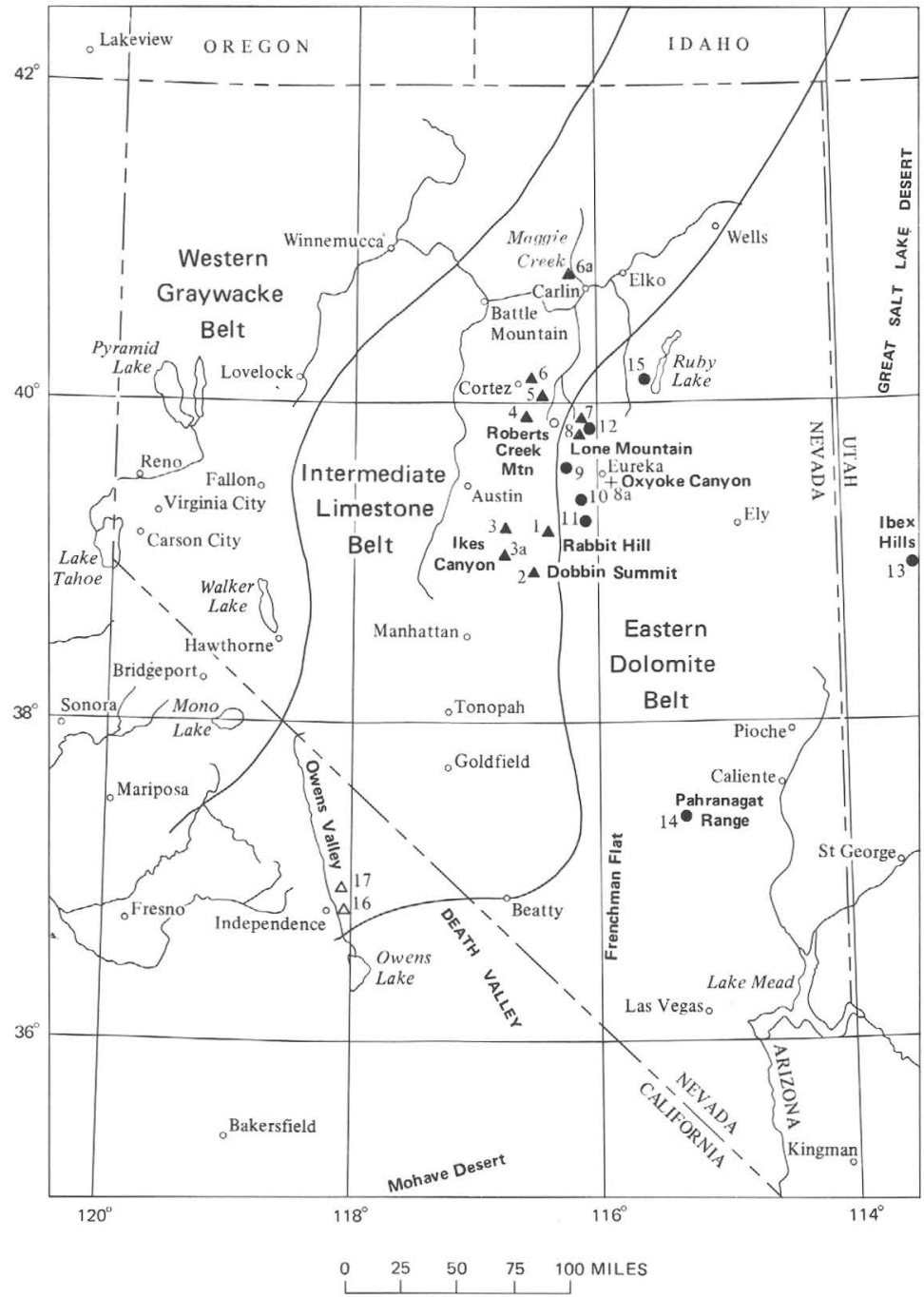

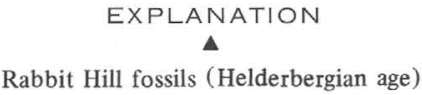

Coral-bearing limestone of possible Rabbit Hill (Helderbergian) age

Lone Mountain Dolomite with fossils of Silurian age, and the upper Lone Mountain-Laketown biofacies

1. Type section of Rabbit Hill Limestone, northern Monitor Range.

2. Rabbit Hill Limestone, Dobbin Summit, medial Monitor Range.

3. Rabbit Hill Limestone, Petes Canyon area, northern Toquima Range.

3a. Rabbit Hill Limestone, Ikes Cany on, Toquima Range.

4. Rabbit Hill Limestone, Walti Ranch, Simpson Park Range.

5. Rabbit Hill Limestone, Coal Canyon, Simpson Park Range.

6. Rabbit Hill Limestone, Cortez Mountains.

6a. Rabbit Hill Limestone, Maggie Creek, Tuscarora Mountains.

7. Beacon Peak Dolomite Member, Bailey Pass area Sulphur Spring Range.

8. Beacon Peak Dolomite Member, South Mulligan Gulch area, Sulphur Spring Range.

8a. Beacon Peak Dolomite Member, type section in Oxyoke Canyon.

9. Lone Mountain Dolomite, type area at Lone Mountain

10. Lone Mountain Dolomite, Mahogany Hills, southern part.

11. Lone Mountain Dolomite, Fish Creek Range, southern part.

12. Lone Mountain Dolomite, Sulphur Spring Range.

13. Laketown Dolomite, Ibex Hills, Confusion Range, Utah.

14. Laketown Dolomite, Pahranagat Range.

15. Silurian dolomite, Ruby Mountains.

16. Vaughn Gulch Limestone (upper part), Inyo Mountains, Calif.

17. Sunday Canyon Formation (upper part), Inyo Mountains, Calif.

FIGURE 1.-Index map of part of the Great Basin showing fossil localities of Rabbit Hill Limestone and Lone Mountain Dolomite and approximate limits of Late Silurian-Early Devonian depositional facies belts.

stone; it contains no diagenetic dolomite. These westernmost Silurian rocks occur at Taylorsville, Calif., just north of the Sierra Nevada, but are best exposed in the Klamath Mountains and southeastern Alaska.

\section{AREAL DISTRIBUTION AND STRATIGRAPHY OF THE RABBIT HILL LIMESTONE}

Within the major intermediate limestone belt (fig. 1) of the southwestern part of the Cordilleran geosyncline, the Rabbit Hill Limestone rests upon Silurian limestones and calcareous shale; its exposures are confined to the more localized Monitor-Simpson Park facies belt in the west-central Great Basin. Scattered outcrops of this formation are known from Dobbin Summit in the Monitor Range northward 140 miles to the Tuscarora Mountains. On the east, in the subparallel north-south Antelope-Roberts Mountains facies belt, distinctive elements of the Rabbit Hill fauna, but not the Rabbit
Hill Limestone itself, occur in dolomitic limestones assigned to the Beacon Peak Dolomite Member at the bottom of the Devonian Nevada Formation.

At Dobbin Summit in the medial part of the Monitor Range, the Rabbit Hill Limestone overlies Silurian limestone containing calcareous shale and is in turn overlain by limestone of uncertain age yielding conodonts reported as Mississippian (J. W. Huddle, written commun., 1966). Twenty miles north at the Rabbit Hill type section, this formation rests upon Silurian graptolite-bearing calcareous shale facies of the Roberts Mountains Formation (Merriam, 1963, p. 42). Because of faulting and erosion, no younger Paleozoic strata are found here.

A key section with respect to stratigraphic relations of the Rabbit Hill Limestone is that in the northern Simpson Park Range, where this formation is conformably underlain by the highest Roberts Mountains Lime- 
stone carrying the Late Silurian faunas of coral zone E. The Devonian Nevada Formation is here in fault contact with the Rabbit Hill Limestone. Limestones containing a Rabbit Hill fauna occur in the Toquima Range (McKee and others, 1972), where they rest conformably on the Roberts Mountains. Outlying areas where this fauna has been collected from limestones are Mount Tenabo in the Cortez Mountains and Maggie Creek northwest of Carlin.

In terms of the major Silurian lithologic belts of the Cordilleran geosyncline referred to above, the Beacon Peak Dolomite containing Rabbit Hill fossils lies areally within the eastern dolomite belt. Here strata of Rabbit Hill Early Devonian age, but differing lithology, underlie Nevada Formation unit 1, which contains fossils of Oriskany (Siegenian) Early Devonian age.

\section{RABBIT HILL, NORTHERN MONITOR RANGE}

About 250 feet of Rabbit Hill Limestone is well exposed at Rabbit Hill in Copenhagen Canyon, Horse Heaven Mountain quadrangle (fig. 1). Here, in the type section at the south end of this small isolated hill, platy limestones and calcareous shales or siltstones separate thick lenses and beds of bioclastic limestone (pl. 8, fig. 15) containing abundant silicified fossils. Throughout the Rabbit Hill type area (figs. 2 and 3) these incompetent beds reveal evidence of drag folding (Merriam, 1963, p. 10). Deformation of these strata is sympathetic to the overthrust beneath which they lie and as a result the Pogonip Group on the west overrode the Roberts Mountains Formation and the Rabbit Hill. Because of the nature of this lower plate dislocation, it has not been determined whether the Rabbit Hill fossils range through a thickness much greater than 250 feet stratigraphically, as these beds are probably repeated across the broad exposure by drag folding and sympathetic slicing beneath the overthrust sole.

All fossils collected from the 250 feet of type section of the Rabbit Hill Limestone are regarded as a single fauna. Other collections of fossils within these deformed strata of the type area north and west of Rabbit Hill itself appear to represent about the same assemblage.

The largest fossil collections from the Rabbit Hill Limestone, those listed in connection with the original description of this formation (Merriam, 1963, p. 43) and described here, came from the southeast side of Rabbit Hill. Conodonts from the type section are listed below under age and correlation. Monograptus has been reported from the Rabbit Hill in its type area, and according to W. B. N. Berry (oral commun., 1971), graptolites have been found at Rabbit Hill. In connection with this study, no instance of interlayering of Monograptus beds with established Rabbit Hill Limestone was observed within the type area. Moreover, it is not unlikely that the thrust slicing within the outcrop belt might bring up slivers of graptolitic rock from Silurian strata of the subjacent Roberts Mountains.

Most of the study fossil material from the Rabbit Hill Limestone in its type area was silicified and was prepared by the acid technique.

The fauna of the Rabbit Hill Limestone at its type section is listed below:

Favosites cf. F. helderbergiae Hall

Striatopora cf. S. gwenensis Amsden

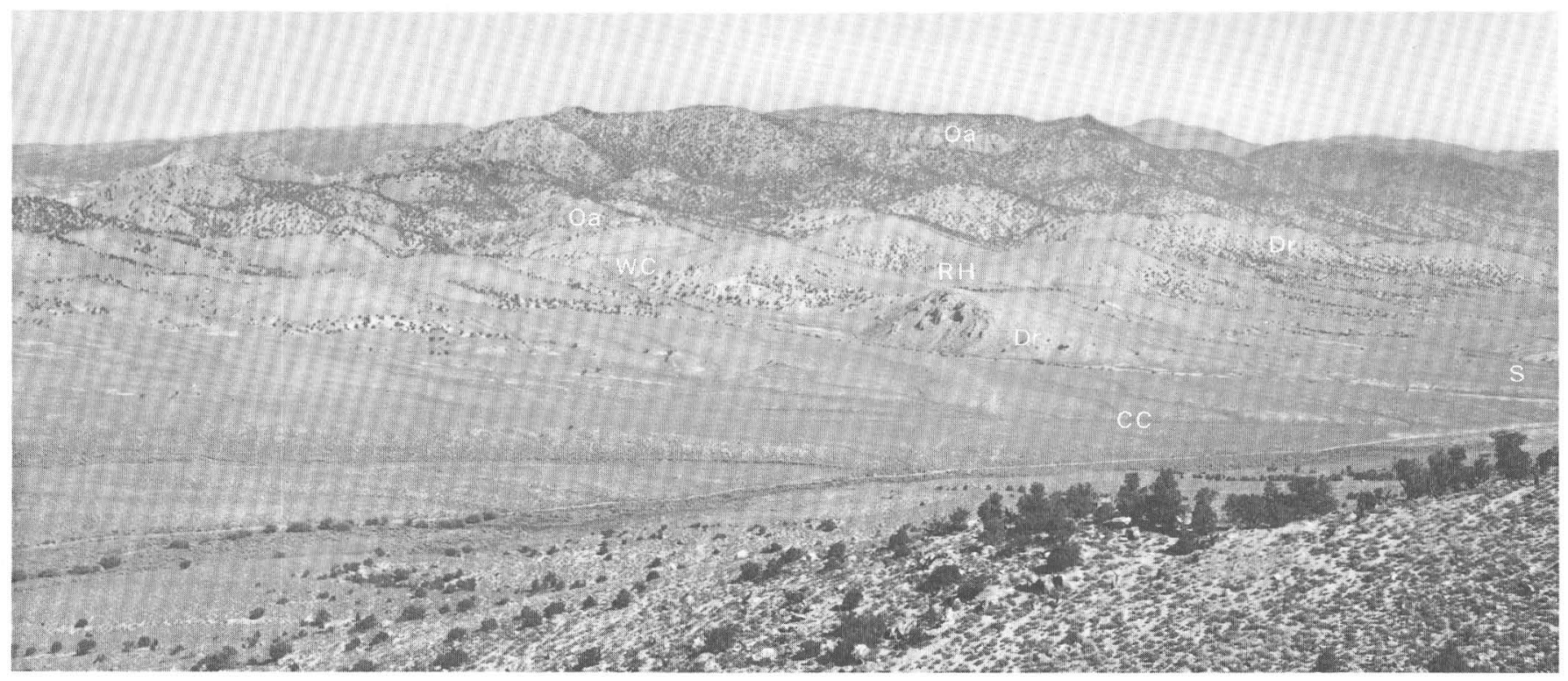

FIGURE 2.-View northwest across Copenhagen Canyon from Martin Ridge, showing Rabbit Hill (RH) right of center, and overthrust Ordovician Antelope Valley limestone cliffs (Oa) in distance. Dr-Rabbit Hill Limestone; S-Silurian graptolitic beds of Roberts Mountains; WC-Whiterock Canyon; CC-Copenhagen Canyon. 


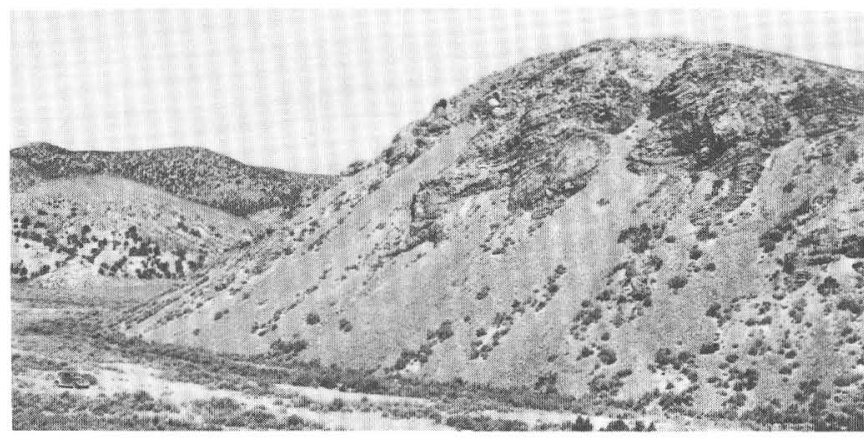

Figure 3.-South side of Rabbit Hill, showing minor drag folds in west-dipping Rabbit Hill Limestone of the type section.

Pleurodictyum nevadensis $\mathrm{n}$. $\mathrm{sp}$.

Pleurodictyum dunbari $\mathrm{n}$. sp.

Syringaxon foerstei $\mathrm{n}$. sp.

Rhipidomella rossi $\mathrm{n} . \mathrm{sp}$.

Levenea subcarinata subsp. antelopensis $\mathrm{n}$. subsp.

Orthostrophia strophomenoides subsp. newberryi $\mathrm{n}$. subsp.

Leptostrophia sp. cf. L. becki tennesseensis Dunbar

(?)Pholidostrophia sp. R

Stropheodonta sp.

Leptaena fremonti $\mathrm{n}$. sp.

Schuchertella cf. S. haraganensis Amsden

Plethorhyncha andersonin. sp.

Meristella martini $\mathrm{n}$. sp.

Ambocoelia sp. a

Leptocoelia occidentalis $\mathrm{n}$. $\mathrm{sp}$.

Trematospira mcbridei $\mathrm{n}$. sp.

Kozlowskiellina nolani $\mathrm{n}$. sp.

Howellella cycloptera subsp. monitorensis n. subsp.

Platyceras sp. a

Platyceras sp. b

Platyceras sp. c

Orthoceras sp.

Leonaspis cf. L. tuberculatus (Hall)

(?) Miraspis sp.

Phacops sp. (large)

hexactinellid sponge spicules

crinoidal debris (abundant)

fucoids (pl. 8, fig. 14)

\section{DOBBIN SUMMIT, MONITOR RANGE}

Excellent exposures of Rabbit Hill Limestone were discovered by F. J. Kleinhampl at Dobbin Summit (fig. 1) in the middle part of the Monitor Range during geologic mapping of northern Nye County, Nev. The Rabbit Hill at this locality resembles that of the type section 20 miles north but is less disturbed and occupies a definable stratigraphic interval within a continuous column. Silurian limestone and calcareous shale conformably underlying the Rabbit Hill contain brach- iopod and graptolite faunas. The overlying limestones, which appear to be conformable, have yielded only conodonts reported to be Mississippian (J. W. Huddle, written commun., 1966).

Within the approximately 400 feet of Rabbit Hill at Dobbin Summit the faunas change in character somewhat passing upward in the column with introduction of the large spirifers Costispirifer and Acrospirifer, not found in the Rabbit Hill Limestone in its type area. The lower fauna is essentially that of the 250-foot interval at the type section. Following is a partial list of Rabbit Hill fossils from the lower 300 feet of the Dobbin Summit exposures:

Favosites cf. F. helderbergiae Hall

Pleurodictyum nevadensis $\mathrm{n}$. $\mathrm{sp}$.

Syringaxon foerstei $\mathrm{n} . \mathrm{sp}$.

Levenea subcarinata subsp. antelopensis $\mathbf{n}$. subsp.

Rhipidomella rossin. $\mathrm{sp}$.

Leptaena fremonti $\mathrm{n}$. sp.

Plethorhyncha andersoni n. sp.

Meristella martini $\mathrm{n}$. sp.

Leptocoelia occidentalis $\mathrm{n}$. sp.

Kozlowskiellina nolani $\mathrm{n}$. sp.

Howellella cycloptera subsp. monitorensis n. subsp.

Leonaspis cf. L. tuberculatus (Hall)

In the upper 100 feet of the Dobbin Summit section, the two large spirifers Costispirifer arenosus subsp. dobbinensis and Acrospirifer kleinhampli appear; these forms are precursors of the later Early Devonian fauna of Nevada unit 1 and Great Basin Devonian coral zone B. Most of the species in the lower fauna continue into the upper interval.

\section{NORTHERN TOQUIMA RANGE}

Ikes Canyon.-Limestones on the south side of this canyon near its mouth contain a fauna of Rabbit Hill age as follows:

Leptaena cf. L. fremonti n. sp.

Orthostrophia cf. O. strophomenoides Hall

Levenea subcarinata subsp. antelopensis n. subsp.

Kolowskiellina nolani $\mathrm{n}$. sp.

Meristella cf. M. martini $\mathrm{n}$. sp.

Limestones underlying those of Rabbit Hill Early Devonian age at Ikes Canyon contain a coral assemblage pertaining to Late Silurian coral zone E, below which are beds containing Monograptus (McKee and others, 1972). In this area, about 400 feet of limestone section including these fossils represents a part of the Roberts Mountains Formation overlain by the Rabbit Hill Limestone equivalent given the local name "McMonnigal Limestone" by Kay and Crawford (1964). Fossils listed from the "McMonnigal" by Kay and Crawford (1964, p. 440) suggest that Lower Devonian beds younger than Rabbit Hill may also be represented. 
Petes Canyon area.-A small structurally disturbed exposure of Rabbit Hill Limestone was discovered by E. H. McKee in the Petes Canyon area during reconnaissance geologic mapping of Lander County, Nev. (fig. 1). At this locality (McKee and Ross, 1969, p. 428), a few feet of deformed Rabbit Hill limestone lies in contact with Silurian graptolitic shales. The fossil assemblage comprises species characterizing the Rabbit Hill type section in the Monitor Range 20 miles east, differing only by the presence of a colonial rugose coral Australophyllum landerensis $\mathrm{n}$. $\mathrm{sp}$. This is one of two occurrences of colonial Rugosa discovered in the Rabbit Hill. Following is a partial list of the Petes Canyon fossil assemblage (Locality M1150) :

Favosites cf. F. helderbergiae Hall

Striatopora cf. S. gwenensis Amsden

Pleurodictyum sp. cf. P. nevadensis $\mathrm{n}$. sp.

Syringaxon foerstei $\mathrm{n}$. sp.

Australophyllum landerensis n. sp.

Levenea subcarinata subsp. antelopensis n. subsp.

Leptocoelia sp.

Kozlowskiellina nolani $\mathrm{n}$. sp.

\section{MCCLUSKY PEAK AREA, SIMPSON PARK RANGE}

A Rabbit Hill Limestone fauna containing abundant trilobites was collected in the foothills east of Walti Ranch (Walti Hot Springs quadrangle) by R. E. Lehner and R. J. Roberts during reconnaissance geologic mapping of Eureka County. No data are available on the relations of these rocks to strata above and below. Following is a partial list of the fossils from this locality (M1074):

Pleurodictyum cf. P. nevadensis n. sp.

Syringaxon foerstei $\mathrm{n}$. sp.

Leptocoelia cf. L. occidentalis n. sp.

Leonaspis cf. L. tuberculatus (Hall)

Phacops sp. (large)

Proetus sp.

Conularia cf. C. huntiana Hall

Conularia cf. C. lata Hall

tentaculitids

\section{COAL CANYON, NORTHERN SIMPSON PARK RANGE}

An especially important reference section for the Silurian and Early Devonian limestone facies of the westerly Monitor-Simpson Park belt is near the mouth of Coal Canyon, Horse Creek Valley quadrangle (fig. 1). The stratigraphy was studied by Winterer and Murphy (1960), who recognized the Rabbit Hill Limestone overlying richly fossiliferous Late Silurian limestone with lenses of coarse depositional limestone breccia. Although this area is faulted considerably, the depositional relations of the Silurian Roberts Mountains For- mation are in some ways better shown here than in the type section of the Roberts Mountains Formation at Roberts Creek Mountain, 12 miles to the southeast. In order to elucidate the stratigraphy and geologic structure, the Coal Creek area was mapped in some detail by Merriam as part of the geologic mapping of the Horse Creek Valley quadrangle by the U.S. Geological Survey.

On the east side of Coal Canyon the upper part of the Roberts Mountains Formation is overlain conformably by 1,100 feet of the Rabbit Hill Limestone. About 500 feet of the uppermost Roberts Mountains along the east side of the canyon appears to be unfaulted and it includes Late Silurian coral zone E (fig. 4). The west side of the Coal Canyon is within the north-south Coal Canyon fault zone, which breaks the continuity of the Silurian column, although no great amount of the section appears to have been cut out by this deformation. West of the Coal Canyon fault zone the limestones of the Roberts Mountains contain a fauna similar to that of Silurian coral zone D.

One-half mile east of Coal Canyon, the Rabbit Hill Limestone is repeated in a seperate fault block, greatly broadening the exposure of this formation. About a mile east of Coal Canyon, Nevada Formation unit 2 crops out in another fault block. No normal stratigraphic boundary of the Nevada upon the Rabbit Hill has been found in this area.

As discussed below under age and correlation of the Rabbit Hill Limestone, the results of this mapping and stratigraphic-paleontologic work do not support the conclusions of Johnson (1965), Johnson and Murphy (1969), and Johnson (1970) regarding age and stratigraphic sequence within the Roberts Mountains Formation of this area.

Rabbit Hill fossils listed below were collected from beds high in the formation. It is probable that the unit can be zoned here on the basis of bed-by-bed collecting. As at the Walti Ranch locality west of McClusky Peak, the Coal Canyon Rabbit Hill contains large trilobites in some abundance:

Syringaxon foerstei $\mathrm{n}$. sp.

Levenea subcarinata subsp. antelopensis n. subsp.

Leptostrophia cf. L. becki tennesseensis Dunbar

Strophonella cf. S. punctulifera (Conrad)

Leptaena fremonti $\mathrm{n}$. sp.

Schuchertella cf. S. haraganensis Amsden

Plethorhyncha andersoni n. sp.

Meristella martini $\mathrm{n} . \mathrm{sp}$.

Howellella cycloptera subsp. monitorensis n. subsp.

(?)Acrospirifer kleinhampli n. sp.

(?) Costispirifer arenosus subsp. dobbinensis n. subsp.

(?) Coelospira sp. (small) 


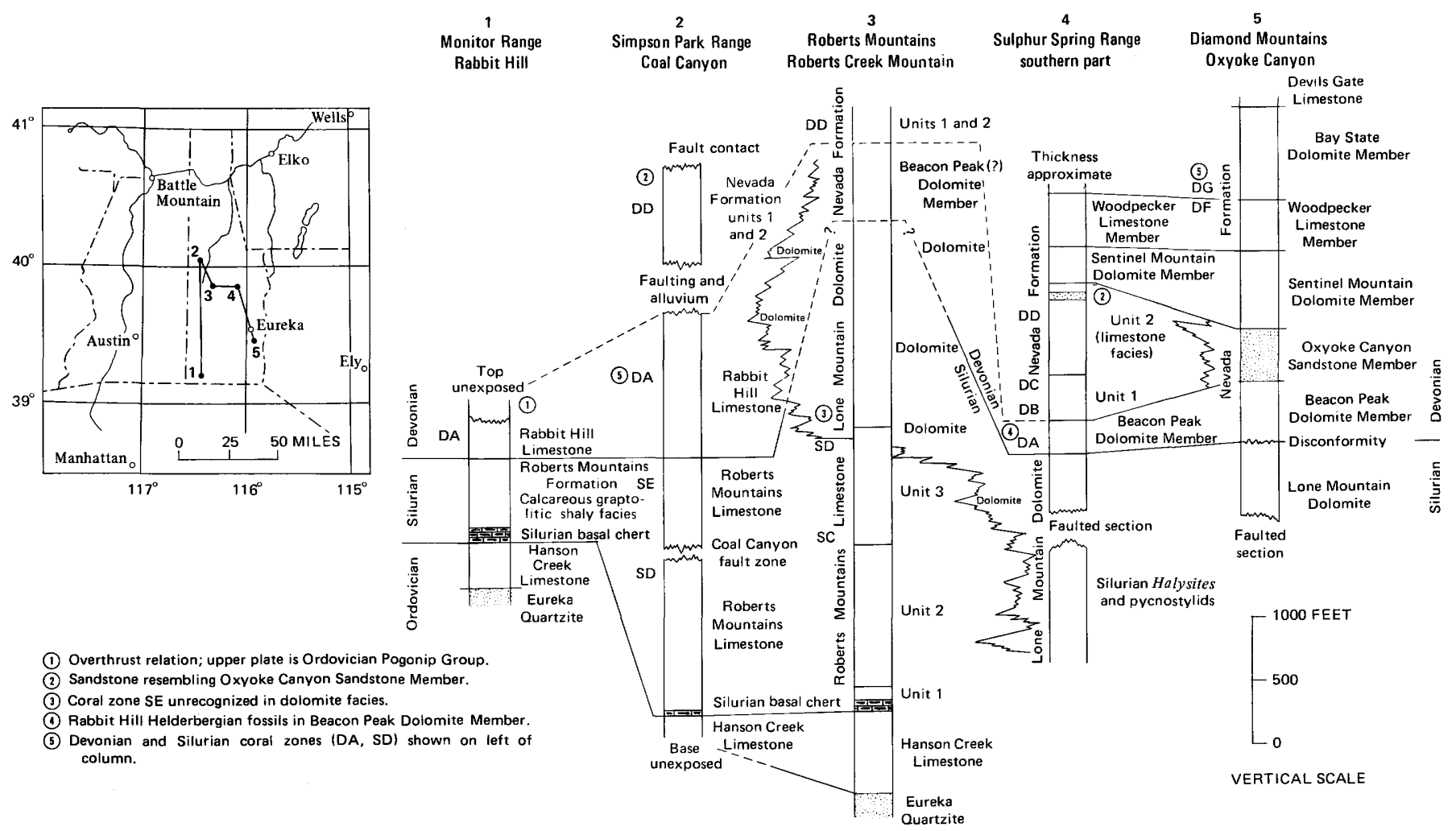

FIGURE 4.-Correlation diagram showing stratigraphic relations of the Rabbit Hill Limestone and inferred equivalence of Lone Mountain Dolomite to the Silurian Roberts Mountains Limestone.

Orthoceras sp.

tentaculitids

Leonaspis cf. L. tuberculatus (Hall)

Phacops sp. (large)

(?) Phacops sp. B, cf. P. canadensis Stumm

dalmanitid (very large)

CORTEZ MOUNTAINS AND TUSCARORA MOUNTAINS

Cortez Mountains.-Rabbit Hill fossils occur in the Wenban Limestone of Gilluly and Masursky (1965, p. 29 ) in the Cortez area 8 miles northwest of the Coal Canyon section, northern Simpson Park Range. The Wenban occupies large areas in the western Cortez Mountains, where it rests upon the Silurian Roberts Mountains Limestone. As described by Gilluly and Masursky, this unit is probably more than 2,000 feet thick and seems to include much of the Devonian. It is fairly evident that a least the lower half represents the Rabbit Hill interval as exposed in Coal Canyon, whereas the upper half probably includes the Nevada Formation, possibly capped by a Late Devonian equivalent of the Devils Gate Limestone. Whether the Rabbit Hill part of the Wenban can on a lithologic basis be mapped separately from the Nevada in that area remains to be demonstrated. Collections of poorly preserved fossils suggesting the Rabbit Hill fauna come from localities along the west Cortez front. At locality M1083 on the southeast side of Mount Tenabo, a collection made by A. J. Boucot contains Syringaxon foerstei $\mathrm{n}$. sp. and Pleurodictyum cf. P. nevadensis $\mathrm{n}$. $\mathrm{sp}$.

Tuscarora Mountains.-Exposures of limestone containing a Rabbit Hill fauna were discovered in the southern Tuscarora Mountains by L. D. Cress during the course of geologic mapping in the Carlin Gold mine area. These disturbed limestones are in contact with the Roberts Mountains Limestone, which in that vicinity contains Silurian Coelospira. At locality M1400 near Maggie Creek, 9 miles northwest of Carlin, the following fossils occur:

Favosites sp. (massive forms)

Pleurodictyum sp. cf. P. lenticularis (Hall)

Syringaxon foerstei $\mathrm{n} . \mathrm{sp}$.

Billingsastraea sp. m

Schuchertella sp. cf. S. haraganensis Amsden

Leptaena cf. L. fremonti $\mathrm{n}$. sp.

Rhipidomella sp.

Leptocoelia sp. (shell fragments only)

Acrospirifer sp.

Nucleospira sp. cf. N. ventricosa (Hall)

Meristella sp.

phacopid trilobite pygidium (small) 
Billingsastraea sp. m (pl. 9, figs. 1, 2) is the earliest known coral of this genus in the Cordilleran belt and is one of two known occurrences of colonial Rugosa in the Rabbit Hill.

\section{BEACON PEAK DOLOMITE, SULPHUR SPRING RANGE}

Geologic mapping of the southern Sulphur Spring Range (fig. 1) under the Kobeh Valley project has disclosed many exposures of dolomite and dolomitic limestone containing a fauna similar to that of the Rabbit Hill Limestone in beds that conformably underlie Nevada Formation unit 1, which carries the Oriskany age (Siegenian) fauna of Devonian coral zone B. Because of their stratigraphic position and lithologic similarity to the Beacon Peak, lowest member of the Nevada Formation in the Eureka mining district, these beds are assigned to that unit (Nolan and others, 1956, p. 42). In its type area, the Beacon Peak (fig. 1) rests disconformably upon Lone Mountain Dolomite (fig. 4) and has yielded no determinable fossils. Although Lone Mountain Dolomite, where best exposed in the southern Sulphur Spring Range, lies in fault contact with the Beacon Peak and the higher Nevada, it is with some confidence believed to directly underlie Beacon Peak beds containing elements of the Rabbit Hill fauna. Fossils from two of the Beacon Peak localities in this area are listed below.

South Mulligan Gulch area (locality M186) :

Pleurodictyum sp.

Favosites sp. (massive)

Syringaxon foerstei $\mathrm{n} . \mathrm{sp}$.

Siphonophrentis sp. B

Levenea subcarinata subsp. antelopensis $\mathrm{n}$. subsp.

Leptocoelia occidentalis $\mathrm{n}$. $\mathrm{sp}$.

Anastrophia cf. A. verneuili (Hall)

Strophonella sp. cf. S. punctulifera (Conrad)

Bailey Pass area (locality M197) :

Favosites sp. (massive)

Syringaxon foerstein. sp.

Levenea subcarinata subsp. antelopensis n. subsp.

Leptocoelia occidentalis $\mathrm{n}$. $\mathrm{sp}$.

Leptaena cf. L. fremonti n. sp.

Anastrophia cf. A. verneuili (Hall)

Meristella sp. (large)

Acrospirifer sp. cf. A. kleinhamplin. sp.

\section{AGE AND CORRELATION OF THE RABBIT HILL LIMESTONE}

The Rabbit Hill Limestone is of Helderbergian (Early Devonian) age. When first examined in the type area (Merriam and Anderson, 1942, p. 1687), these beds were included with the Roberts Mountains Formation as a part of the Silurian System. Comparative study of brachiopods in 1947 strongly favored an Early Devonian age. Among its abundant and distinctive brachiopod genera, Leptocoelia appears first in this formation (table 1); so far as is known, this genus is confined to the Devonian and is especially characteristic of the Early Devonian. The genus Ambocoelia in the Rabbit Hill confirms a Devonian age. Supporting

TABLE 1.-Characteristic fossils of the Rabbit Hill Limestone and Beacon Peak Dolomite Member of the Nevada Formation

\begin{tabular}{|c|c|c|c|c|c|}
\hline \multicolumn{2}{|c|}{$\begin{array}{l}\text { Monitor } \\
\text { Range }\end{array}$} & \multirow[b]{2}{*}{ 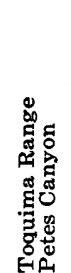 } & \multicolumn{2}{|c|}{$\begin{array}{c}\text { Simpson } \\
\text { Park } \\
\text { Range }\end{array}$} & \\
\hline 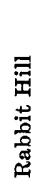 & 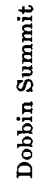 & & 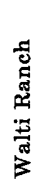 & 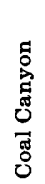 & 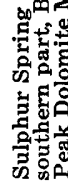 \\
\hline
\end{tabular}

Favosites cf. $F$.

helderbergiae Hall

Favosites sp. (massive)

Striatopora cf. S. gwenesis

Pleurodictyum nevadensis $\mathrm{n}$. $\mathbf{s p}$...

Pleurodictyum sp ......................

Pleurodictyum dunbari $\mathrm{n} . \mathrm{sp}$.......

Syringaxon foerstei $\mathrm{n} . \mathrm{sp}$............

Australophyllum sp. $\mathbf{r}$...

Rhipidomella rossi $\mathrm{n}$. sp

Levenea subcarinata subsp.

antelopensis n. subsp .............

Orthostrophia strophomenoides

subsp. newberryi $\mathrm{n}$. subsp.

tennesseensis Dunbar

(?) Pholidostrophia sp. $\mathrm{R}$

Stropheodonta sp

Strophonella sp. cf. S.

punctulifera (Conrad)

Leptaena fremonti $\mathrm{n} . \mathrm{sp}$

Schuchertella cf. S.

haraganensis Amsden

Plethorhyncha andersoni in

Meristella martini $\mathrm{n}$. sp ............ $\times$

Meristella sp. (large)

Ambocoelia sp. a

Leptocoelia occidentalis n. sp .... $\times$

Leptocoelia sp

Trematospira mcbridei $\mathrm{n}$ sp

Kozlowskiellina nolani n. sp ....... $\times$

Howellella cycloptera subsp.

monitorensis n. subsp ..............

Acrospirifer kleinhampli n. sp .... ....

Costispirifer arenosus subsp.

dobbinensis $\mathrm{n}$. subsp

(?) Coelospira sp. (small)

Anastrophia cf. A verneuili (Hall)

Platyceras sp. a

Platyceras sp. b

Platyceras sp. c

Orthoceras sp

Conularia of $C$. huntiana Hall....

Conularia cf. C. lata Hall .........

tentaculitids

Leonaspis cf. L. tuberculatus

(Hall)

(?) Miraspis $\mathrm{sp}$

Phacops sp. (large)

(?) Phacops sp. B, cf. $P$.

canadensis Stumm

dalmanitid (very large)
Proetus sp

\begin{tabular}{|c|c|c|c|c|}
\hline$\times$ & $x$ & .... & $\ldots$. & $\cdots$ \\
\hline .... & $\cdots$ & $\ldots$ & .... & $x$ \\
\hline$\cdots$ & $x$ & $\cdots$ & $\cdots$ & $\cdots$ \\
\hline$x$ & cf. & cf. & .... & $\ldots$ \\
\hline$\cdots$ & $\cdots$ & $\cdots$ & $\cdots$ & $x$ \\
\hline .. & $\cdots$ & $\cdots$ & $\cdots$ & $\cdots$ \\
\hline$x$ & $x$ & $x$ & $x$ & $x$ \\
\hline 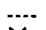 & $x$ & $\cdots$ & $\cdots$ & $\cdots$ \\
\hline$x$ & $\cdots$ & $-\cdots$ & $\cdots$ & $\cdots$ \\
\hline$x$ & $x$ & .... & $x$ & $x$ \\
\hline$\ldots$ & $\cdots$ & $\cdots$ & $\cdots$ & $\cdots$ \\
\hline$\cdots$ & $\ldots$ & $\ldots$ & $x$ & $\cdots$ \\
\hline$\cdots$ & $\cdots$ & $\cdots$ & $\cdots$ & $\cdots$ \\
\hline$\cdots$ & $\cdots$ & $\cdots$ & $\cdots$ & $\cdots$ \\
\hline$\cdots$ & $\cdots$ & .... & $x$ & $x$ \\
\hline$x$ & $\cdots$ & .... & $x$ & cf. \\
\hline$\cdots$ & $\cdots$ & $\cdots$ & $x$ & $\cdots$ \\
\hline$x$ & .... & $\ldots$ & $X$ & $\ldots$ \\
\hline$x$ & $\ldots$ & .... & $x$ & $\cdots$ \\
\hline$\cdots$ & $\cdots$ & $\cdots$ & .... & \\
\hline$\dddot{x}$ & $\cdots$ & of & $\cdots$ & $Y$ \\
\hline$\times$ & 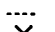 & cf. & $\cdots$ & $x$ \\
\hline$\cdots$ & $x$ & $\cdots$ & $\cdots$ & .... \\
\hline & … & $\cdots$ & $\cdots$ & $\cdots$ \\
\hline$x$ & $x$ & -.. & $\cdots$ & $\cdots$ \\
\hline$\frac{x}{x}$ & $\cdots$ & $\cdots-$ & $x$ & \\
\hline & $\cdots$ & $\cdots$ & CI. & Cr. \\
\hline$x$ & $\cdots$ & $\cdots$ & cf. & $\cdots$ \\
\hline -... & $\cdots$ & $\cdots$ & $x$ & $\cdots$ \\
\hline$\cdots$ & $\cdots$ & $\cdots$ & $\cdots$ & $x$ \\
\hline$\cdots$ & $\cdots$ & $\cdots$ & $\cdots$ & $\cdots$ \\
\hline$\cdots$ & $\cdots$ & $\cdots$ & $\cdots$ & $\cdots$ \\
\hline$\cdots \cdot$ & $\cdots \cdot$ & $\cdots$ & $\because$ & $\cdots$ \\
\hline$\cdots$ & $\cdots$ & $\because$. & $x$ & $\cdots$ \\
\hline$\cdots$ & $\cdots$ & $\underset{y}{x}$ & $\cdots$ & $\cdots$ \\
\hline$\cdots$ & $\cdots$ & X & $\ddot{x}$ & .... \\
\hline$\cdots$ & $\cdots \cdot$ & $x$ & $x$ & $\cdots$ \\
\hline$x$ & $\cdots$ & $x$ & $x$ & $\cdots$ \\
\hline$\cdots$ & $\cdots$ & $\because$ & $\cdots$ & $\cdots$ \\
\hline$\cdots$ & $\cdots$ & $x$ & $x$ & \\
\hline$\cdots$ & $\cdots$ & $\cdots$ & $x$ & $\cdots$ \\
\hline$\cdots$ & $\cdots$ & $\cdots$ & $x$ & $\cdots$ \\
\hline$\cdots$ & $\cdots$ & $x$ & $\cdots$ & $\ldots$ \\
\hline
\end{tabular}


brachiopod evidence is provided by the presence of Devonian types of Trematospira in the Rabbit Hill and of Anastrophia related to A. verneuili in the correlative Beacon Peak Dolomite Member. Moreover, Early Devonian Acrospirifer and large Costispirifer of the Oriskany C. arenosus type occur in higher Rabbit Hill beds. The colonial rugose coral Billingsastraea sp. $\mathrm{m}$ of the Rabbit Hill at Tuscarora Mountains further supports a Devonian age, this genus not being recorded in older rocks.

Paleontologic comparison of the Rabbit Hill and Beacon Peak faunas with Devonian faunas of eastern North America demonstrates that several distinctive western species and subspecies have near relatives in Helderbergian (Early Devonian) strata of New York, Tennessee, and Oklahoma. Among fossil indicators of eastern Helderberg affinity are two species of Pleurodictyum, the trilobite Leonaspis of the L. tuberculatus type, and also the brachiopods Levenea subcarinata subsp. antelopensis, Howellella cycloptera subsp. monitorensis, Anastrophia cf. A. verneuili, and Orthostrophia strophomenoides subsp. newberryi.

Evidence from study of Rabbit Hill conodonts also supports an Early Devonian age. A conodont faunule extracted from samples collected by the writer in the upper 100 feet of the type Rabbit Hill Limestone at Rabbit Hill is reported on by J. W. Huddle (written commun., 1969) as follows:

\footnotetext{
***Your collections M1326-1 and M1326-2 from the upper 100 feet of Rabbit Hill Limestone at the Rabbit Hill type section, Copenhagen Canyon, Horse Heaven quad., Nevada both contain abundant specimens of Icriodus latericrescens $\mathbf{n}$. subsp. B of Klapper 1969, I. latericrescens huddlei Klapper and Ziegler and single cusp conodonts generally referred to Acodina which seem to be associated with Icriodus latericrescens.

These forms are characteristic of Johnson-Boucot (1968) Spinulosa-Zone I and Klapper et al in press Zone-5 (and Klapper, 1969) which is thought to be Siegenian.
}

Further permissive evidence of Siegenian age is provided by conodonts from the uppermost part of the Rabbit Hill at Coal Canyon, Simpson Park Range (locality M1310), identified by Huddle as follows:

Belodella resimus Philip

Icriodus cf. I. latericrescens $\mathrm{n}$. subsp. B of Klapper Icriodus sp.

Ostracods from a locality near the base of the Wenban Limestone near Cortez (Gilluly and Masursky, $1965, p .31$ ) have been reported on by Jean M. Berdan, of the U.S. Geological Survey. The lower part of the Wenban is with assurance the lower part of the Rabbit Hill Limestone of the neighboring Simpson Park Range. Following are the ostracods listed by Berdan: Mesomphalus sp. Velibeyrichia sp. n. gen. aff. Welleria Saccarchites sp.
Aechmina? sp.

Acanthoscapha sp.

Tricornina sp.

Tubilibairdia sp.

Bairdia sp. aff. B. leguminoides

As several of the genera listed range upward from Late Silurian into Early Devonian, it was not found possible on the basis of ostracods alone to fix the age of these beds.

Samples from the uppermost part of the Rabbit Hill Limestone at Coal Canyon (locality M1310) yielding Belodella resimus Philip and other conodonts reported on by Huddle also contain ostracods, identified by Jean M. Berdan as follows:

***The ostracodes include Thlipsura sp. aff. T. furca Roth, Parahealdia? aff. P.? convexoris Swartz and Whitmore, and several unidentifiable species. Thlipsura furca was originally described from the Haragan Limestone of Oklahoma. Parahealdia? convexoris was described from the upper part of the Manlius Limestone in southeastern New York; however, there is an undescribed species in the Port Ewen Limestone in the Hudson Valley which is even closer to the form from the Rabbit Hill. These two species suggest that this part of the Rabbit Hill has affinities with the Helderbergian of the Appalachian region.

Because of the high stratigraphic position of this ostracod and conodont locality (M1310), it is assumed that these beds are younger than those in the Wenban Limestone near Cortez that yielded ostracods identified by Berdan.

On the basis of fossil evidence, the westerly Rabbit Hill Limestone is correlated with the Beacon Peak Dolomite Member in the more easterly AntelopeRoberts Mountains facies belt (fig. 4). Fossils common to the two differing carbonate facies are similar types of Pleurodictyum, Syringaxon foerstei n. sp., Leptocoelia occidentalis n. sp., Levenea subcarinata subsp. antelopensis, and similar Acrospirifer.

Limestones possibly correlative with the Rabbit Hill occur in the Mazourka Canyon area, northern Inyo Mountains, Calif. (fig. 1), where they lie in the upper part of the Vaughn Gulch Limestone and in the upper part of the more or less equivalent Sunday Canyon Formation (Ross, 1966, p. 31-35). These beds contain species of the colonial rugose coral Australophyllum similar to Rabbit Hill $A$. landerensis. The middle and lower parts of both formations are Silurian (Merriam, 1973a). Late Silurian coral zone E underlies the uppermost Vaughn Gulch division, which contains Australophyllum sp. v of possible Helderbergian age. Australophyllum stevensi in upper beds of the Sunday Canyon Formation is also conceivably Early Devonian. As mapped by Ross (1966, pl. 1), the Vaughn Gulch Limestone changes northward into the more shaly Sunday Canyon Formation, in which Silurian graptolitic depos- 
its predominate, a facies change comparable to that noted elsewhere in correlative Roberts Mountains Limestone of the major intermediate limestone belt.

With a single exception, there are no recorded occurrences of the Rabbit Hill fauna in western North America outside of the Great Basin. Glacial cobbles collected by F. K. Miller, of the U.S. Geological Survey (oral commun., 1965), in the Chewelah area, Stevens County, northeastern Washington, contain a fauna of Rabbit Hill affinity. Among the fossils are Syringaxon sp., Pleurodictyum cf. P. lenticularis (Hall), Levenea cf. L. subcarinata (Hall), and a species of Leptocoelia.

Data from stratigraphic position of the Rabbit Hill Limestone and correlative Beacon Peak Dolomite Member have a bearing upon the age and correlation of these units in a world sense. In the Sulphur Spring Range the Beacon Peak occupies the interval between the Lone Mountain Dolomite (below) and Nevada Formation unit 1 (above) (fig. 4). Lower beds of Nevada Formation unit 1 carrying Costispirifer arenosus and Acrospirifer as well as the rugose corals of Devonian coral zone B are of Oriskany age, or Siegenian of the European scale. Hence a pre-Oriskany or Helderbergian age assignment of the Beacon Peak and Rabbit Hill is appropriate. Presence in the topmost part of the Rabbit Hill Limestone at Dobbin Summit of the large Costispirifer arenosus subsp. dobbinensis and the large Acrospirifer kleinhampli strongly suggests that the fauna of these upper beds foreshadows and may be little older than that of Nevada Formation unit 1 in Devonian coral zone B with its Oriskany or Siegenian elements. Moreover, the reported Siegenian age of the uppermost Rabbit Hill based on conodont evidence seems to be in harmony with these findings.

Fixing of the age of the base of the Rabbit Hill Limestone is made possible by its conformable stratigraphic relation to underlying coral-bearing limestones in the northern Simpson Park Range. At Coal Canyon (fig. 1) the topmost Roberts Mountains Limestone contains a large and diverse coral assemblage of Gotlandian aspect and Late Silurian (Ludlovian) age (fig. 4). These distinctive corals characterize Silurian coral zone $\mathrm{E}$ of the Great Basin and include the Silurian rugose corals Mucophyllum, Kodonophyllum, and Chonophyllum, and pycnostylids. They are not known in Devonian rocks, and, with the entire fauna of Silurian coral zone $\mathrm{E}$, do not reappear in the Rabbit Hill. Conclusions by Johnson and others (Johnson, 1965; Johnson, 1970; Johnson and Murphy, 1969) regarding a possible Devonian age of the uppermost Roberts Mountains Limestone at Coal Canyon are not confirmed by the rugose coral and brachiopod studies of Merriam (1973a). The Late Silurian fauna of coral zone $\mathrm{E}$ has been found in the Toquima Range, Nev. (McKee and others, 1972), where it underlies limestone with a probable Rabbit Hill fauna. A similar relation is recognized (Merriam, 1973a) in the Vaughn Gulch Limestone of the northern Inyo Mountains, Calif.

In summary, an Early Devonian (Helderbergian) age for these Great Basin strata is supported by the stratigraphic position of Rabbit Hill Limestone at Coal Canyon, Simpson Park Range, above Late Silurian (Ludlovian) beds of Silurian coral zone $\mathrm{E}$, by the occurrence of faunas of Rabbit Hill affinity below strata of Oriskany (Siegenian) age in the Sulphur Spring Range, and most convincingly by paleontologic similarities of the Rabbit Hill fauna to faunas of eastern Helderberg formations.

\section{LONE MOUNTAIN DOLOMITE}

The name "Lone Mountain Limestone" originally applied by Hague (1892, p. 57-62) to a more inclusive section was later, as "Lone Mountain Formation," restricted by Merriam (1940, p. $13 ; 1963$, p. 39) to some 1,750 feet of blocky saccharoidal dolomite overlain by the Nevada Formation and underlain by a lower darker gray dolomite unit. At Lone Mountain, Eureka County, Nev., within the designated type area, there has been previous to this report no fossil evidence applicable to the restricted Lone Mountain Dolomite. Presumed Silurian age was predicated upon stratigraphic position beneath Lower Devonian beds of Nevada unit 1 , coupled with possible correlation of underlying darker gray dolomite with Silurian limestones named Roberts Mountains Formation by Merriam (1940, p. 11).

In other Great Basin areas, the name Lone Mountain Dolomite has been adopted rather loosely in some instances for lithologically comparable and usually rather barren dolomites beneath an assumed SilurianDevonian boundary. Whereas the Lone Mountain Dolomite was long assumed to be a westerly continuation of the Laketown Dolomite of the eastern Great Basin, there has previous to this report been no published fossil evidence to bear out this view.

In recent years geologic mapping of areas within and bordering upon the Eureka mining district has disclosed stratigraphic sections in which the Lone Mountain Dolomite is quite fossiliferous, and where the stratigraphic relations to contiguous formations may be determined. These sections lie in the southern Diamond Mountains, the southern Fish Creek Range, the Mahogany Hills, and the southern Sulphur Spring Range.

\section{LONE MOUNTAIN DOLOMITE, LONE MOUNTAIN}

The "Lone Mountain Formation" of the type area as redefined by Merriam in 1940 (p. 13, 19) included only 
the upper "1,570 feet" of Hague's inclusive "Lone Mountain Limestone" (Hague, 1892, p. 57). So delimited, the Lone Mountain of Merriam is underlain by about 750 feet of darker weathering dolomite, at that time considered to be a southerly dolomite facies of the Roberts Mountains Formation, which in its type area is mainly limestone rich in Silurian fossils (Merriam, 1940, pl. 2, fig. 2).

Recent disclosures call for some realinement of the dolomite units at Lone Mountain in the interest of clarity and simplicity. Because of the dolomitic nature of the entire section upward from the Silurian basal chert member to the Devonian Nevada Formation, it is here proposed to refer to the lower 750 -foot darker weathering dolomite in the Lone Mountain Dolomite as Lone Mountain unit 1, designating the upper unit or Lone Mountain Dolomite (restricted) of Merriam (1940) as Lone Mountain unit 2 (fig. 5). So reapportioned, Hague's original "Lone Mountain Limestone" comprises at the bottom a Late Ordovician dolomitic facies of the Hanson Creek Formation overlain by Lone Mountain Dolomite units 1 and 2. Of special stratigraphic significance at Lone Mountain (fig. 6) is the Silurian basal chert, which is as much as 80 feet thick in places and forms the bottom member of Lone Mountain Dolomite unit 1.

Although no positively identifiable fossils have been collected from the type section of Lone Mountain Dolomite during these investigations, poorly preserved organic remains are not uncommon. Hague (1892, p. 59, 61 ) and Walcott $(1884$, p. 4, 273) make reference to the presence at Lone Mountain of "Halysites catenulatus." Because Hague gives its horizon as "within 50 feet of the quartzite," it is likely this was an halysitid normally occurring in the Late Ordovician Hanson

\begin{tabular}{|c|c|c|c|}
\hline Haque (1892) & Merriam (1940) & \multicolumn{2}{|c|}{ Merriam (this report) } \\
\hline Nevada Limestone & Nevada Formation & $\begin{array}{c}\text { Nevada Formation } \\
\text { unit } 1\end{array}$ & $\begin{array}{c}\text { Early Devonian } \\
\text { (early Emsian) }\end{array}$ \\
\hline \multirow{4}{*}{$\begin{array}{l}\text { Lone Mountain } \\
\text { Limestone }\end{array}$} & $\begin{array}{l}\text { Lone Mountain } \\
\text { Formation } \\
\text { (restricted) }\end{array}$ & $\begin{array}{l}\text { Lone Mountain } \\
\text { Dolomite } \\
\text { unit } 2\end{array}$ & \multirow{2}{*}{ Silurian } \\
\hline & $\begin{array}{c}\text { Roberts Mountains } \\
\text { Formation } \\
\text { (dolomite facies) }\end{array}$ & $\begin{array}{l}\text { Lone Mountain } \\
\text { Dolomite } \\
\text { unit } 1\end{array}$ & \\
\hline & $-101-101$ & 101010 & \\
\hline & $\begin{array}{c}\text { Hanson Creek } \\
\text { Formation } \\
\text { (dolomite facies) }\end{array}$ & $\begin{array}{l}\text { Hanson Creek } \\
\text { Formation } \\
\text { (dolomite facies) }\end{array}$ & \multirow{3}{*}{ Ordovician } \\
\hline Eureka Quartzite & Eureka Quartzite & Eureka Quartzite & \\
\hline Pogonip Limestone & Pogonip Limestone & Pogonip Group & \\
\hline
\end{tabular}

FIGURE 5.-Diagram illustrating history and present usage of the stratigraphic name Lone Mountain Dolomite.
Creek and Ely Springs Dolomite. Walcott (1884, p. 4) alludes to its poor preservation in stating that doubt existed in the mind of James Hall, who examined the fossil, as to the validity of the identification. Poorly preserved tabulate corals were collected by Merriam $(1940$, p. 13,20$)$ in the 1930's at the base of Lone Mountain unit 2. These corals were considered more closely allied to Syringopora than Halysites.

Many exposures of dark-gray dolomite showing conspicuous organic traces have been found in Lone Mountain unit 2 during detailed mapping of the Lone Mountain area by the U.S. Geological Survey. Carbonaceous dolomites containing the poorly preserved fossils are most numerous in the upper 750 feet of the Lone Mountain and appear to be lenses or pods surrounded by lighter gray barren rock. The dark pods appear to have been loci of especially prolific organic activity within which the magnesian recrystallization was somewhat less destructive of fossil structure than in the lighter rock.

Definite rugose coral structures occur at two localities (M1122, M1122a) east of Charcoal Gulch on the southeast side of Lone Mountain, probably within the upper 500 feet of the Lone Mountain Dolomite. Material from locality M1122 shows broken, partly macerated Rugosa with fairly large subcylindrical corallites of diameters up to three-fourths of an inch and lamellar septa (pl. 11, fig. 32). These fossils suggest the Silurian genus Entelophyllum, well represented in the higher Lone Mountain Dolomite of the Mahogany Hills and Fish Creek Range as discussed below.

\section{LONE MOUNTAIN DOLOMITE,}

Dark-gray carbonaceous dolomites containing abundant silicified fossils occur within the upper 500 feet of the Lone Mountain Dolomite 11/4 miles north of the summit of Wood Cone Peak and 2 miles south-southwest of Combs Peak (Merriam, 1963, p. 41). As at Lone Mountain in the upper part of unit 2, these fossilbearing carbonaceous dolomites are lenticular within the lighter gray barren dolomite and appear to occupy about the same stratigraphic interval (fig. 7). At locality M1112 the coral beds are quite extensive and are occupied almost solely by the colonial bushy Entelophyllum (pl. 10, fig. 11).

Southwest of locality M1112, and presumably much lower in the section, Halysites is present in dark-gray dolomite that possibly represents Lone Mountain unit 1. Still lower, in considerably faulted range-front terrane, are fossiliferous limestones of the Late Ordovician (Richmondian) horizons representing the Hanson Creek Formation (fig. 7). Walcott's original locality for the "Trenton" fauna, now known to be that of the Han- 


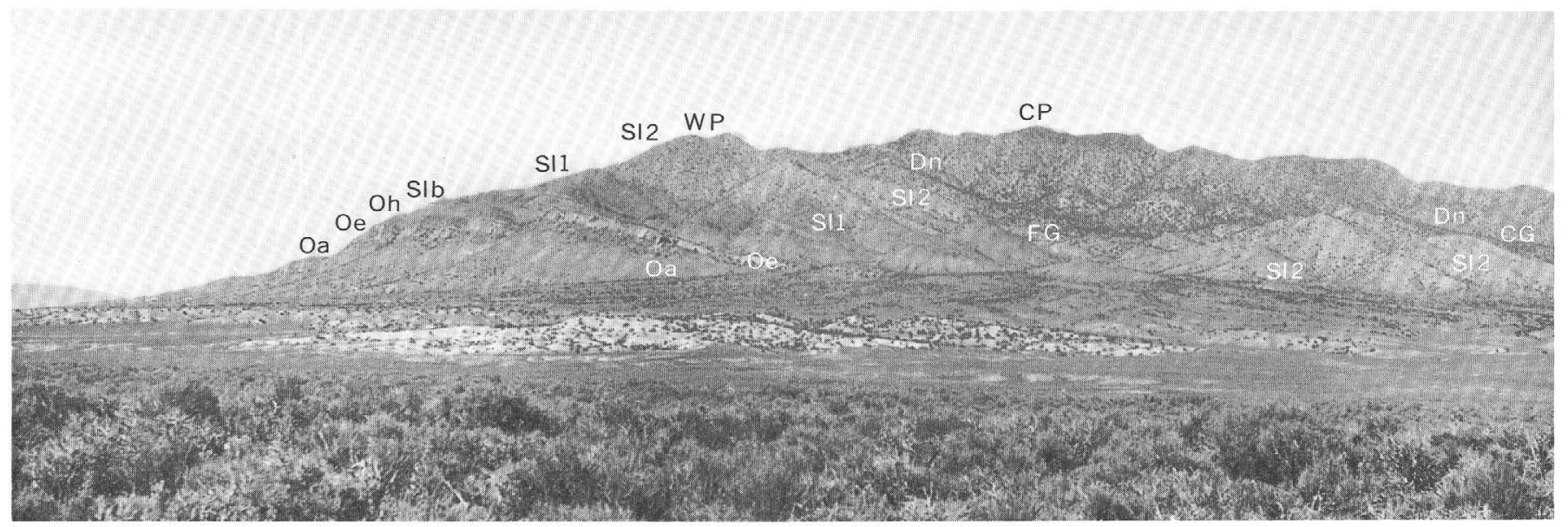

FIGURE 6.-South side of Lone Mountain, showing east-dipping stratigraphic section upward from Ordovician Antelope Valley

Limestone (Oa) on left to Devonian Nevada Formation (Dn) on right. Note color contrast differentiating darker gray Lone Mountain unit 1 (Sl1) from lighter gray Lone Mountain unit 2 (Sl2). Oe-Eureka Quartzite; Oh-Hanson Creek Dolomite facies; Slb-Silurian basal chert; WP-West Peak; CP_Central Peak; FG-Fossil Gulch; CG-Charcoal Gulch.

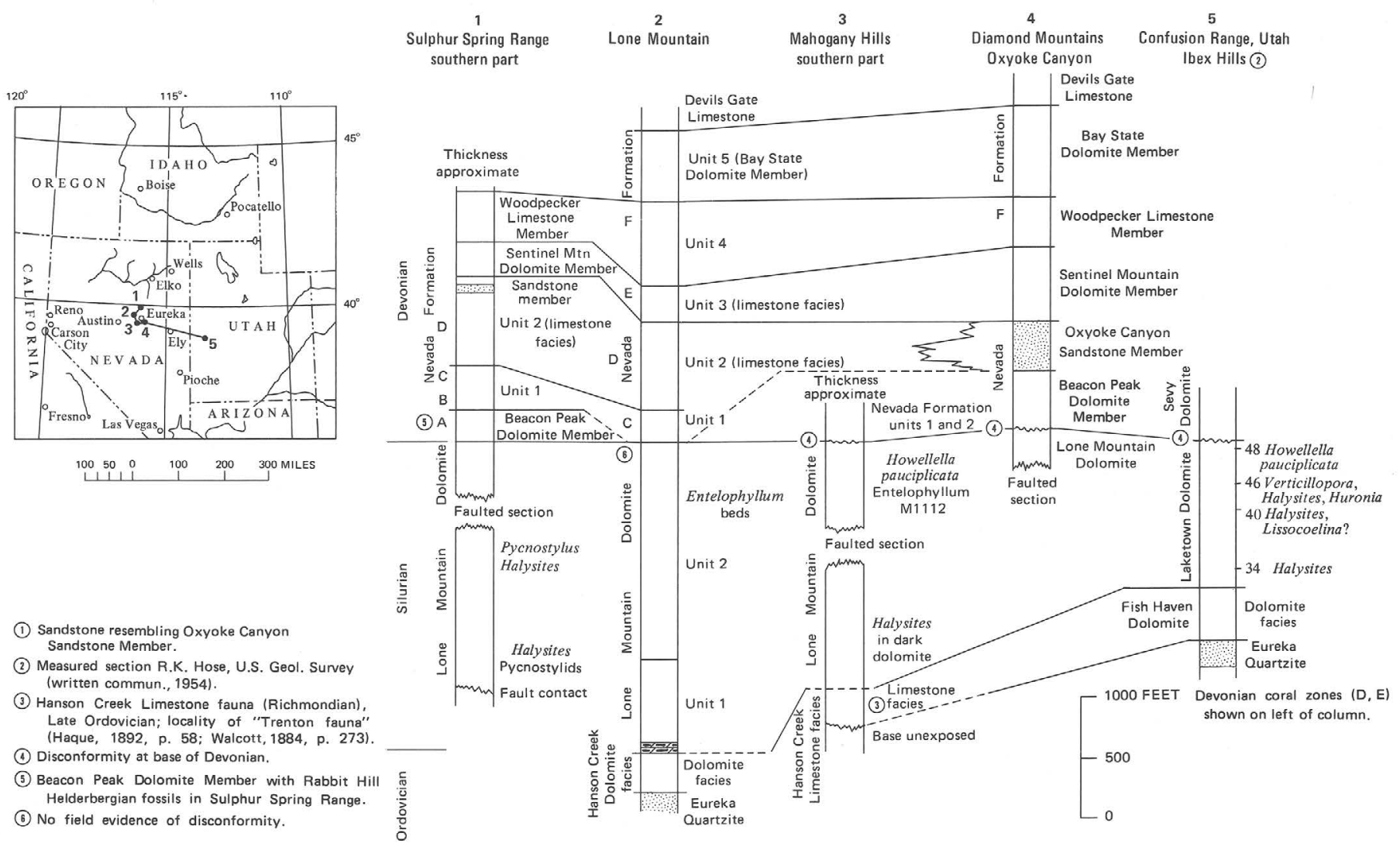

FIGURE 7.-Correlation diagram showing stratigraphic relations of the Lone Mountain Dolomite and its equivalence to the Laketown Dolomite of Utah.

son Creek limestone facies, is situated here near BM7201, about nine-tenths of a mile north-northeast of Wood Cone, and one-half mile southeast of Entelophyllum locality M1112.

Except for abundant Entelophyllum, the fauna of locality M1112 is small and nondiverse, including only the following forms:

(?) Thamnopora sp.

Entelophyllum engelmanni $\mathrm{n}$. sp.

Camarotoechia sp.

?Hyattidina sp. $\mathbf{f}$

Howellella pauciplicata Waite 


\section{LONE MOUNTAIN DOLOMITE, SOUTHERN FISH CREEK RANGE}

Low-dipping, considerably disturbed Lone Mountain Dolomite is in contact with the Nevada Formation $31 / 2$ miles southwest of Fish Creek Springs, where these Devonian rocks and overlying Devils Gate Limestone make up the north end of Fenstermaker Mountain. Blocky Silurian dolomites exposed here lie within the upper part of the Lone Mountain Dolomite and yield well-preserved silicified coral-brachiopod assemblages (pl. 12, fig. 25) differing somewhat from the fauna of locality M1112 in the southern Mahogany Hills. Because of complex faulting not yet mapped out, the relation to the Nevada Formation is not entirely clear. It appears probable that these fossil-bearing dolomites directly underlie the Nevada and occupy about the same stratigraphic interval as the Mahogany Hills beds of locality M1112 and the fossil-bearing dolomite lenses at Lone Mountain locality M1122 (fig. 7).

Lone Mountain Dolomite faunas from two Fish Creek Range localities, both close to the south boundary of the Bellevue Peak quadrangle, are described here. The localities are M1113, near the range crest, and M1087, a quarter of a mile west. The fauna from locality M1087 (pl. 12, fig. 25) is listed below:

slender ramose favositids (thin-walled)

Alveolites sp.

Entelophyllum engelmanni subsp. b

Tryplasma sp.

?Hyattidina sp. $\mathrm{f}$

Hindella sp. a

Howellella smithi Waite

The fauna collected at locality M1113 follows:

massive favositids (small colonies)

?Thamnopora sp.

Entelophyllum eurekaensis n. sp.

Entelophyllum sp. cf. E. engelmanni subsp. b

Salopina sp. f

Camarotoechia pahranagatensis Waite

Camarotoechia sp. b

Camarotoechia sp.f

Atrypa sp. f

?Hyattidina sp. f

Howellella smithi Waite

\section{LONE MOUNTAIN DOLOMITE,} SULPHUR SPRING RANGE

Characteristic Silurian dolomites assigned to the Lone Mountain form the large fault block at East Ridge, south of Romano Ranch (fig. 1). The eastdipping blocky dolomite is in contact on the west with the Nevada Formation along the high-angle northsouth Romano fault. The areal geology and structure as mapped in this vicinity strongly suggest that Lone
Mountain Dolomite also underlies the Early Devonian Beacon Peak Dolomite Member between the Romano fault and the parallel major Mulligan Gap fault 2 miles west.

The Lone Mountain Dolomite of East Ridge is about 1,200 feet thick. Silicified corals were collected at locality M1121 near the fault in lower strata of this block and at locality M1148 on the east in the higher beds. Both faunas represent a Halysites-pycnostylid biofacies (fig. 7). That of the lower horizon contains a large undescribed pycnostylid genus with flaring calice (pl. 11, figs. 28, 29) in association with Halysites. The upper fauna includes a great abundance of the slender phaceloid Pycnostylus (pl. 11, fig. 30) together with Halysites.

Corals of the East Ridge Halysites-pycnostylid biofacies are not related to those of the higher Lone Mountain in the Mahogany Hills and Fish Creek Range, which are the Entelophyllum-Howellella association designated below as the upper Lone Mountain-Laketown biofacies. It is probable that these East Ridge dolomites are a lower interval of the Lone Mountain sequence, possibly including some of Lone Mountain unit 1.

\section{AGE AND CORRELATION OF THE LONE MOUNTAIN DOLOMITE}

All identifiable fossils collected during this investigation from Lone Mountain Dolomite of the type area are of Silurian age. They include the EntelophyllumHowellella assemblages of the Mahogany Hills and Fish Creek Range and those of the Halysites-pycnostylid facies of the Sulphur Spring Range (fig. 7). Rugose corals of the genus Entelophyllum and the pycnostylids are unknown in Devonian rocks; halysitids of the types occurring in the Lone Mountain are not known to have survived beyond the Silurian.

Whereas studies of the Lone Mountain Dolomite at Lone Mountain itself have brought forth no unequivocal evidence of Silurian age in that immediate locality, nearby exposures of this dolomite have yielded an abundance of Silurian fossil material. The three described Entelophyllum-bearing faunas from localities M1112, M1087, and M1113 have species in common, and while differing somewhat in detail, probably all represent a single stratigraphic interval corresponding to the upper 500 feet of Lone Mountain unit 2 at Lone Mountain. These faunas are of Late Silurian age and characterize the upper Lone Mountain-Laketown biofacies (table 2). Moreover, discovery in the Lone Mountain Dolomite at Lone Mountain of coralline lenses comprising large volumes of comminuted rugose corals suggesting Entelophyllum (pl. 11, fig. 32) seems to bear out the possible equivalence of these beds in 
TABLE 2.-Characteristic fossils of the upper Lone MountainLaketown biofaces

\begin{tabular}{|c|c|c|c|c|c|}
\hline & \multicolumn{3}{|c|}{$\begin{array}{c}\text { Lone Mountain } \\
\text { Dolomite } \\
\text { (Upper part only) }\end{array}$} & \multirow{3}{*}{ 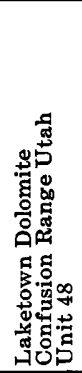 } & \multirow{3}{*}{ 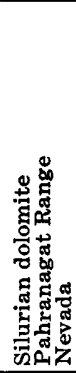 } \\
\hline & \multirow{2}{*}{ 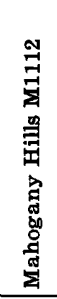 } & \multicolumn{2}{|c|}{ 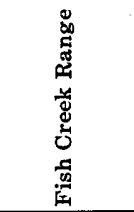 } & & \\
\hline & & 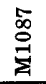 & $\underset{\Xi}{\stackrel{\infty}{\Xi}}$ & & \\
\hline Massive favositids & & & & & \\
\hline $\begin{array}{l}\text { (small colonies) } \\
\text { Ramose favositids }\end{array}$ & $\cdots$ & $\cdots \cdot$ & $x$ & $\cdots$ & $\cdots$ \\
\hline $\begin{array}{l}\text { Ramose tavositids } \\
\text { (thin-walled) }\end{array}$ & & $x$ & & $\ldots$ & \\
\hline ?Thamnopora sp & $x$ & ..... & $x$ & $\cdots$ & .... \\
\hline $\begin{array}{l}\text { Alveolites sp } \\
\text { Entelophyllum engelmanni }\end{array}$ & .... & $x$ & .... & .... & $\cdots$ \\
\hline n. sp & $x$ & $\cdots$ & ... & .... & ? \\
\hline Entelophyllum engelmanni & & & & & \\
\hline Entelophyllum eurekaensis & $\cdots$ & $\hat{n}$ & 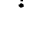 & $\cdots$ & $\cdots$ \\
\hline n. sp & -..- & & $x$ & .... & -... \\
\hline Tryplasma sp & .... & $x$ & & .... & .... \\
\hline Salopina sp. $\mathbf{f}$ & $\cdots$ & .... & $x$ & & .... \\
\hline $\begin{array}{l}\text { Camarotoechia } \mathrm{sp} \\
\text { Camarotoechia pahranagatensis }\end{array}$ & $x$ & $\cdots$ & .... & .... & \\
\hline Waite & & ... & $x$ & $\mathrm{x}$ & $x$ \\
\hline Camarotoechia sp. b & $\cdots$. & $\cdots$ & $x$ & $\cdots$ & $?$ \\
\hline Camarotoechia sp. f & .... & .... & $x$ & .... & $\cdots$ \\
\hline Atrypella carinata Johnson ......... & $\cdots$ & .... & $\dddot{x}$ & .... & $\underset{x}{x}$ \\
\hline $\begin{array}{l}\text { Atrypa sp. f } \\
\text { ?Hyattidina sp f }\end{array}$ & $\dddot{x}$ & $\dddot{x}$ & $\begin{array}{l}x \\
x\end{array}$ & $\cdots$ & $x$ \\
\hline ?Hyattidina hesperalis Waite .... & $\ldots$ & & $\ldots$ & $\cdots \cdot$ & $\ddot{x}$ \\
\hline 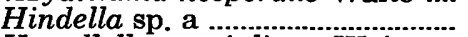 & 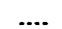 & $x$ & .... & .... & \\
\hline Howellella pauciplicata Waite .... & $\dddot{x}$ & & ..... & $\dddot{x}$ & ..... \\
\hline $\begin{array}{l}\text { Howellella smithi Waite ............... } \\
\text { ?Meristina sn }\end{array}$ & .... & $x$ & $x$ & $?$ & $x$ \\
\hline 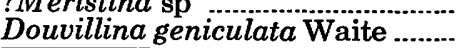 & $\cdots$. & $\cdots .$. & $\cdots$. & $\begin{array}{l}x \\
x\end{array}$ & $\cdots$ \\
\hline
\end{tabular}

Lone Mountain unit 2 to the Late Silurian Entelophyllum beds of the Mahogany Hills and Fish Creek Range.

Comparison of the Entelophyllum-Howellella assemblages of the Lone Mountain Dolomite with Silurian faunas of the higher Laketown Dolomite in the eastern Great Basin provides good evidence of age and correlation. A suitable Laketown reference section for present purposes is that of the Ibex Hills, Confusion Range, Utah, mapped and measured by R. K. Hose (written communs., 1954-1964). The Ibex Hills Laketown (fig. 7) is about 1,200 feet thick, underlain by Late Ordovician Fish Haven Dolomite and overlain disconformably by probable Early Devonian beds of the Sevy Dolomite. Units 29 to 49 of the Hose measured section fall within the Laketown. Laketown unit 48, about 60 feet below the Sevy contact, contains the diagnostic Late Silurian fauna of the upper Lone Mountain-Laketown biofacies, whose key fossil is Howellella pauciplicata Waite. No Entelophyllum has yet been collected from unit 48 of the Ibex Hills section, although generally in the eastern Great Basin Laketown this rugose coral is present. Upper Laketown beds correlative with unit 48 occur in the Pahranagat Range of southern Nevada (Waite, 1956; Johnson and Reso, 1964). In that area the characterizing Howellella is the coarser ribbed species $H$. smithi Waite, present also in the Lone Mountain of Fish Creek Range, but doubtfully represented in unit 48 of the Confusion Range, where pauciplicata predominates.

Other Silurian faunas characterize the greater part of the Ibex Hills Laketown Dolomite below unit 48. The faunas in units 29 upward to unit 47 have not yet been found in the Lone Mountain Dolomite. Of special interest is the abundance of the dasycladacean alga Verticillopora in unit 46, a genus that reaches its peak in Late Silurian coral zone D of the Silurian limestone facies of the westerly Great Basin.

Halysites appears to be absent or very uncommon in the Great Basin higher Silurian, not having been recognized in the upper Lone Mountain-Laketown biofacies or in Late Silurian coral zones D and $\mathrm{E}$ of the westerly limestone facies. However, halysitids are clearly facies controlled and generally through the Silurian and Late Ordovician may be very abundant or totally lacking in a given assemblage where other corals are common.

Pycnostylid Rugosa are distinctive Silurian corals, seemingly also subject to some degree of facies control. The Halysites-pycnostylid association of the Silurian dolomite of Sulphur Spring Range has not yet been identified in the lower Laketown, where it is to be expected. In the Silurian limestone facies of the westerly Great Basin, the pycnostylid genera range upward to coral zones $\mathrm{D}$ and $\mathrm{E}$ but, being absent from the Rabbit Hill, are not known to survive into the Early Devonian.

The Lone Mountain Dolomite is assumed to be correlative for the most part with the Roberts Mountains Limestone, an assumption based upon stratigraphic position, but, because of biofacies differences, unsupported by direct paleontologic evidence (fig. 4). Conclusive evidence of lateral intertonguing of the two carbonate facies is unavailable; however, within the type section of the Roberts Mountains Limestone, interbeds of dolomitic limestone and dolomite (Winterer and Murphy, 1960) suggest the possibility of such a relation in that area. In this type section, the uppermost beds of the Roberts Mountains Limestone have largely changed over to dolomite. These uppermost strata fall in Late Silurian coral zone D. Above zone D, the section is barren dolomite wherein highest Silurian coral zone $\mathrm{E}$ would be expected; it is not improbable that these dolomites may represent a northerly tongue of Lone Mountain Dolomite unit 2, above which lies the Beacon Peak Dolomite Member of Rabbit Hill (Early Devonian) age (fig. 8). 


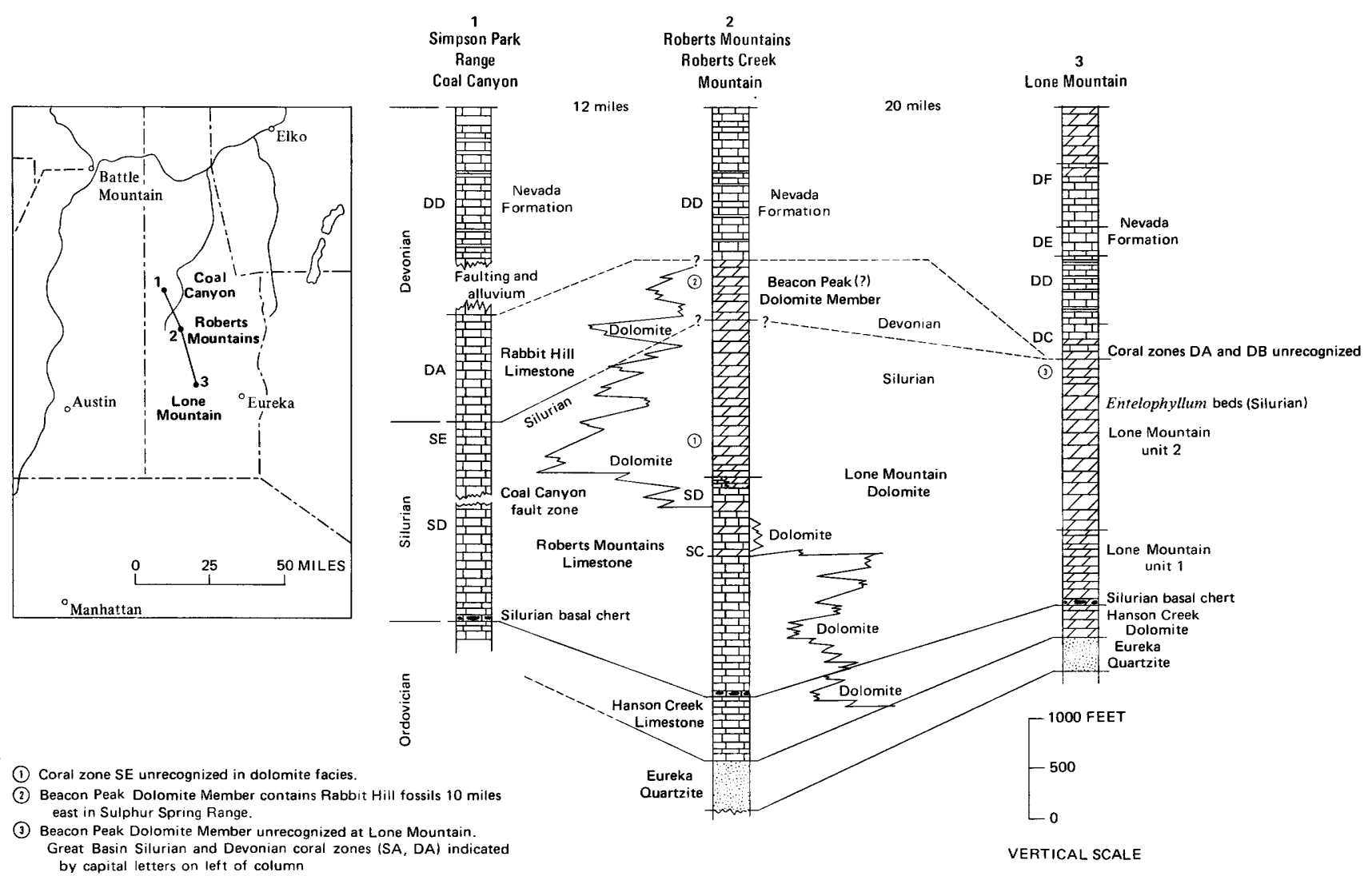

FIGURE 8.-Correlation diagram showing stratigraphic relation of Rabbit Hill Limestone to Lone Mountain Dolomite as interpreted.

Fossils have not been found in the uppermost Lone Mountain Dolomite in its type area, that is, within the 300 feet or so between Late Silurian EntelophyllumHowellella beds and the Devonian Nevada Formation. Accordingly, in a negative way it is not entirely possible at present to rule out Early, perhaps pre-Helderberg, Devonian age for the highest Lone Mountain. Factors to be weighed are Helderbergian age of the lowest Nevada member, the Beacon Peak Dolomite Member, plus absence from the type Lone Mountain section at Lone Mountain of the Beacon Peak. In that section Nevada Formation unit 1 with post-Helderberg fossils rests conformably upon the Lone Mountain as mapped. In view of a seemingly gradational boundary, it is therefore not inconceivable that beds mapped as the highest barren Lone Mountain may occupy the Helderbergian time-stratigraphic interval.

On tenuous evidence, the Lone Mountain Dolomite has in recent years been interpreted by several paleontologists as at least partly Devonian, a view seemingly inspired by earlier suggested lateral equivalence of the Rabbit Hill Limestone to the upper part of the Lone Mountain Dolomite (Merriam, 1963, fig. 7). A further complication has been added by conodont, graptolite, and brachiopod investigators (Clark and Ethington, 1966; Johnson, 1970), who conclude that a not inconsiderable upper part of the Roberts Mountains Limestone is also Devonian. These age conclusions are not substantiated by Merriam's (1973a) rugose coral and brachiopod studies. Clearly an appraisal and adjustment of these conflicting paleontologic findings is called for, taking into account a review of the stratigraphic ranges of all fossil groups represented in the light of more recent structural and stratigraphic study of the enclosing rocks.

\section{CONCLUSIONS REGARDING RELATION OF RABBIT HILL LIMESTONE TO LONE MOUNTAIN DOLOMITE}

Among objectives of this investigation is elucidation of age and stratigraphic relation of the Rabbit Hill Limestone to the Lone Mountain Dolomite, the two units having previously been viewed as locally occupying similar or overlapping stratigraphic positions and never occurring in the same stratigraphic column (fig. 8). These paleontologic studies strongly indicate that the Rabbit Hill fauna is of Helderbergian (Early Devonian) age and is accordingly younger than the highest 
known Lone Mountain Dolomite fossil horizon, which is Late Silurian and lies no more than 400 feet below the top of the dolomite formation. This factor greatly narrows down the possibility of age equivalence of any of the Rabbit Hill to the uppermost part of the Lone Mountain.

Factors of stratigraphic significance bearing upon the Rabbit Hill-Lone Mountain relation are: (1) probable time-stratigraphic equivalence of Lone Mountain unit 1 and much of Lone Mountain unit 2 to the Roberts Mountains Limestone of Silurian age as previously demonstrated, and (2) the stratigraphic position of the Beacon Peak Dolomite Member carrying a Rabbit Hill fauna and overlying the Lone Mountain Dolomite (figs. 4, 7).

Failure to discover fossils in the uppermost type area Lone Mountain Dolomite leaves open the possibility that the beds in unit 2 carrying the Silurian (Ludlovian) upper Lone Mountain-Laketown assemblages might conceivably be succeeded upward by a very Early Devonian or Helderbergian fauna. However, the biofacies differences here might well eliminate a direct fossil comparison. The Lone Mountain faunas of unit 2 include the spiriferoid genus Howellella and massive tabulate corals, each represented by differing species in the Rabbit Hill, but in general the biofacies differences are great. In fact, it would appear that the magnitude of this faunal disparity, enhanced as it is by facies, may be somewhat disproportionate to actual age difference between the two formations.

\section{GREAT BASIN SILURIAN AND DEVONIAN CORAL ZONES}

Rugose corals were used to zone Silurian and Devonian strata of the Great Basin (Merriam, 1971a, 1971b). The five proposed Silurian zones are lettered A through $\mathrm{E}$ in ascending stratigraphic order. Zone $\mathrm{A}$ is of Early Silurian age (Llandoverian), B and C are Middle Silurian (Wenlockian), and D and E are Late Silurian (Ludlovian). The nine Devonian coral zones are lettered A through I; of these zones, A, B, and C are Early Devonian, zone D is Early and early Middle Devonian, zones E, F, G, and probably the lower half of $\mathrm{H}$ are Middle Devonian, and coral zone $\mathrm{I}$ is Late Devonian. In both systems, the coral zonation is best shown in the limestone facies (figs. 4, 7, 8).

The Rabbit Hill Limestone is within Devonian coral zone A, characterized by the Syringaxon biofacies. There is a very profound discontinuity in rugose coral history between Late Silurian coral zone $\mathrm{E}$ of the uppermost Roberts Mountains Limestone and Early Devonian coral zone A of the conformably overlying Rabbit Hill. Following a great burst of coral evolution in Silurian coral zone E, nearly all of the rugose coral genera drop out abruptly. In most places the Rugosa continue to be represented in coral zone A of the Rabbit Hill by the one small solitary genus Syringaxon, which is abundant. The next great burst of rugose coral evolution took place locally in Devonian coral zone D.

Knowledge of Rugosa in Silurian dolomite facies of the Lone Mountain and the Laketown Dolomite is at this time not sufficient for coral zonation. Rugosa are locally abundant in several horizons of the Laketown, ranging from beds with Palaeocyclus, possibly corresponding to Silurian coral zone A (Merriam, 1973a), to those higher in the column containing Rhabdocyclus, Tryplasma, lykophyllids, and Entelophyllum.

\section{SYSTEMATIC AND DESCRIPTIVE PALEONTOLOGY}

This general paleontologic study of Rabbit Hill and Lone Mountain faunas is concurrent with research upon Great Basin Silurian and Early Devonian rugose corals. Among its objectives are support for and strengthening of conclusions based on the coral studies.

Questions of stratigraphic superposition, age, and geologic correlation having to do with setting up of reliable composite reference sections for the Great Basin Silurian and Devonian require integration of all lines of paleontologic evidence derived from study of as much as possible of entire faunas. The rugose corals are by themselves insufficient for achieving these objectives. New genera and species of Great Basin Rugosa are in some instances unknown in distant standard sections of eastern North America and the Old World, hence at present are of no direct comparative value in this regard.

Among megafossils normally associated ecologically with Rugosa, the brachiopods have been relied upon for age conclusions within the Cordilleran mid-Paleozoic. The determinative advantages of good brachiopod interiors, where these shells, like those of the Rabbit Hill and the Lone Mountain, are excellently preserved by silicification are well known. Among rugose corals in these environments, fine structures of wall and septa are usually damaged or nearly destroyed by the same silicification processes. Brachiopods named and described are those silicified and most abundant in the Rabbit Hill bioclastic limestones and in the dark-gray carbonaceous facies of the Lone Mountain. Other brachiopods are at this time insufficiently represented for naming and full description, and much remains to be done with the paleontology of this fossil group. Systematics of the Rugosa are entered into more fully in contributions dealing wholly with this Order (Merriam, $1973 \mathrm{a}, 1973 \mathrm{~b}, 1973 \mathrm{c})$. Of less commonly silicified fossils, few have been touched upon. Mollusca, Echinoderms, bryozoans, ostracods, and most of the trilobites 
remain to be described.

Rabbit Hill platy limestones and shaly-silty laminated beds are locally rich in trilobite remains and in places contain conularids and abundant tentaculites. Near Walti Ranch (locality M1074) in the Simpson Park Range, thin-bedded Rabbit Hill limestones yield well-preserved Conularia comparable to Hall's $C$. huntiana of the eastern Helderbergian (pl. 2, figs. 18-20).

In the taxonomic sense, greater faunal differentiation of the Rabbit Hill as compared with the upper Lone Mountain is noteworthy. Of the Rabbit Hill silicified bioclastic limestone fossils from the type section, some 26 taxa are listed here; these are only part of the total preserved fossil assemblages in this facies. Fossils are numerous in the restricted upper Lone Mountain darkgray carbonaceous dolomite facies, but the preserved fauna is small and nondiverse. Only 11 taxa were recognized in the most diverse of these faunas from the Fish Creek Range. Some upward adjustment of this species count would doubtless be called for, if unsilicified, and therefore unrecovered, shell-bearing forms were known. It is seemingly a safe assumption that the diagenetic dolomite faunas of the higher Lone Mountain were initially far less diverse taxonomically than the Rabbit Hill Limestone bioclastic facies. Marine environmental differences, little understood, would appear to be a logical explanation for these disparities in faunal diversity. In general, shallow-water marine conditions during accumulation of the richly fossiliferous Rabbit Hill Limestones must have been far more hospitable than during deposition of the diagenetic upper Lone Mountain dolomites. Except for the local carbonaceous bodies, these magnesian carbonates are sparsely fossiliferous or completely barren.

\section{FOSSILS OF THE RABBIT HILL LIMESTONE \\ AND BEACON PEAK DOLOMITE MEMBER OF THE NEVADA FORMATION \\ Order TABULATA Edwards and Haime, 1850 Family FAVOSITIDAE Dana, 1846}

Tabulate corals are the abundant and usually the only colonial corals in the Early Devonian Rabbit Hill Limestone. As limestone builders, the favositids contributed much of the material in bioclastic facies, where they are accompanied by the small solitary rugose coral Syringaxon. Tabulates continue to predominate in coralline facies to the early Middle Devonian beds in the higher part of coral zone $\mathrm{D}$, where colonial Rugosa become fairly common. In Middle Devonian coral zone F, colonial Rugosa outnumber Tabulata and the favositids are no longer common in this region. The local Devonian evolutionary peak of the Tabulata was thus reached in argillaceous limestone facies of Nevada Formation unit 2 and coral zone D, in which they outnumber Rugosa. As noted by earlier researchers in corals the Paleozoic Tabulata throve better in muddy seas than did colonial rugose corals, especially in turbid bottom environments, where stromatoporoids are absent. Similar argillaceous sediments are present as interbeds in both Rabbit Hill Limestone and Nevada unit 2. Tabulates are numerous in each case, and in each the stromatoporoids are quite uncommon.

Three subfamilies of the Favositidae are present in the Rabbit Hill Limestone: (1) Favositinae with the genus Favosites; (2) Pachyporinae with Striatopora; and (3) Micheliniinae with Pleurodictyum. Genera that would be expected here, but have not been identified, are Emmonsia, Alveolites, Coenites, and Cladopora. There are no Heliolitidae or Syringoporinae in the collections, and Halysitidae are absent.

Of special stratigraphic significance is the abundance of Pleurodictyum of the $P$. lenticulare lineage; as noted by several investigators, these corals characterize rocks of about Helderbergian age in widely scattered parts of the globe. Other and distinct Pleurodictyum lineages occur in strata of Silurian age (Amsden, 1949, p. 100) and range upward to the Middle Devonian (Fenton and Fenton, 1936; Stumm, 1950, 1964). Neither Pleurodictyum nor Striatopora have been recognized among the abundant tabulate corals of Nevada unit 2 and coral zone D.

\section{Subfamily FAVOSITINAE Dana, 1846 \\ Genus Favosites Lamarck, 1816 \\ Favosites cf. F. helderbergiae Hall Plate 1, figures 16-19}

The corallum of these massive favositids ranges from large and globose or hemispherical more than 6 inches in greatest diameter to elongate, digitate, and lobose. Coralla with polygonal corallites $2-3 \mathrm{~mm}$ (millimeters) wide are distinguishable from those with small corallites less than $2 \mathrm{~mm}$. The wall is uniformly thin, a characteristic of the genus; mural pores are moderately large, disposed in either one or two vertical columns per polygonal wall facet, have thickened rims, and may be covered by a pore plate. Tabulae are usually rather widely spaced, but in some coralla are closely set. Septal spines are minute and very scarce. There are no squamulae as in Emmonsia and certain species of the Favosites alpenesis group of Swann (1947). Numerous small reproductive offsets characterize some mature coralla. These are usually but not always situated internally at wall facet junction angles.

At present there are no criteria by which these Rabbit Hill massive favositids may be distinguished from surficially similar species of Nevada unit 2 (coral zone D). But available material of zone D Favosites does not reveal the numerous reproductive offsets on distal surfaces of mature coralla. Certain species of Silurian Favosites like $F$. gothlandicus, the type species, 
attain a uniformly much greater corallite width than any of those in the Rabbit Hill or Nevada Formations.

\section{Subfamily PACHYPORINAE Gerth, 1921 \\ Genus Striatopora Hall, 1851 . \\ Striatopora cf. S. gwenensis Amsden \\ Plate 1, figures 1, 3-6}

1963 Striatopora sp. cf. S. gwenensis Amsden. Merriam, p. 43.

Branching Striatopora with thick cylindrical coralla tapering toward tips of branches. Septal ridges prominent in polygonal calices. Corallite walls thickened throughout by lamellar stereoplasm; greatly thickened laterally around calices. Tabulae few and widely spaced, visible in axial vicinity only, obscured by stereoplasm peripherally. No mural pores or septal spines recognized.

Presence of large and small calices suggests corallite dimorphism as recognized by Oliver (1966) for the type species, $S$. flexuosa Hall. The type species appears to be of more slender construction and internally the "a-corallites" of Oliver (1966, p. 449) are much thinner walled axially than in the Rabbit Hill species.

Associated with Striatopora in the Rabbit Hill Limestone are slender ramose tabulates of similar external appearance, but possessing thin walls, calices without septal ridges, and large mural pores. Some of these have an external holotheca covering calices of earlier formed parts of a corallum.

Striatopora has not been recognized in Devonian strata above the Rabbit Hill Helderbergian of the Great Basin.

Subfamily MICHELINIINAE Waagen and Wentzel, 1886 Genus Pleurodictyum Goldfuss, 1829

Type species.-Pleurodictyum problematicum Goldfuss 1829. Lower Devonian, Coblenz and Eifel districts, Germany. Known in the form of molds with supposed worm tube in basal part.

Diagnosis.-Corallum round-ovoid transversely with convex upper surface; base unevenly flattened, concave or convex. Corallites large, radiating outward from conical initial chamber, numbering from one to more than 30 , with thick hexagonal walls pierced by irregularly spaced large communicating pores or canals. Walls with as many as 36 rudimentary pseudosepta composed of vertically arranged spines. Tabulae are usually absent.

Remarks.-Like P. ploblematicum, the Lower Devonian representatives of this genus are in part low, laterally extended encrusting forms, the shape of whose corallum base is more or less determined by the substratum. There are uncertainties about the structure of problematicum because of its preservation as moulds. Sardeson (1896, p. 292) interpreted this species as lacking tabulae, but later workers (Stumm, 1950), p. 210; Hill and Stumm, 1956, p. F466) regard Pleuro- dictyum broadly as having tabulae. Middle Devonian large forms with numerous tabulae and radially elongate corallites are assigned by some workers to Michelinia de Koninck 1841 (Sardeson, 1896, p. 294; Hill and Stumm, 1956, p. F466). By others, Michelinia is regarded as a synonym. According to Stumm (1964, p. 77-79), Pleurodictyum includes larger species with abundant tabulae, and the genus is subdivided as two subgenera; Pleurodictyum (Pleurodictyum) has walls with strong septal ridges or spines and complete or incomplete tabulae, and Pleurodictyum (Procteria) Davis has smooth to faintly striate walls, cystose tabellae in the larger species, and a thick papillose peritheca. Some Middle Devonian forms such as "P." stylopora (Eaton?) from the Hamilton Group of North America also are reported to have the tubular vermiform body of problematicum.

Simple species of Pleurodictyum having only a few large corallites were present in the Silurian as represented by $P$. tennesseensis Amsden of the Brownsport Formation (Amsden, 1949, p. 100, pl. XXIII, figs. 1-3). Dunbar (1920, p. 118, pl. 1, figs. 5-7) has described $P$. trifoliatum, another primitive more or less encrusting species from the Lower Devonian Rockhouse Shale of Tennessee.

If the new Rabbit Hill Helderbergian species Pleurodictyum dunbari is correctly assigned generically, it seems likely that these forms early developed two growth habits, the low encrusting one like $P$. lenticulare (Hall) of the New York Helderberg and the elongate stalked form like $P$. dunbari, which appears to be related to the Silurian $P$. tennesseensis and to the more abbreviated trifoliatum.

\section{Pleurodictyum nevadensis n. sp. Plate 1, figures 7-12}

1963 Michelinia sp., Merriam, p. 43.

Type material.-Holotype, USNM 159517; paratype USNM 159518. Lower Devonian Rabbit Hill Limestone, locality M404.

Diagnosis.-Pleurodictyum with large polygonal radiating corallites having a deep calice. Base usually shows conical apex of initial corallite and may be flattened, convex, or concave. Pseudosepta, as many as 40 , consist of longitudinal rows of close-set short spines. Walls thick, pierced by large connecting pores in common wall of adjoining chambers, about 80 openings per square centimeter. No tabulae, the deeper medial calices extending almost to proximal (basal) wall. Smaller newly added chambers near periphery.

Remarks.-This form varies from encrusting individuals with roughly concave proximal surface and thickened peritheca to erect forms with projecting 
initial corallite and very deep calices. Larger encrusting individuals have 36 corallites, but usually the erect ones have many fewer.

Pleurodictyum nevadensis $\mathrm{n}$. sp. resembles the Helderbergian $P$. lenticularis (Hall). Hall's figures (1887, pl. III, figs. $1,2,3,5)$ show large corallites that are shallow with broad floor, not open nearly to the corallum base as in $P$. nevadensis. It is not known whether the broad corallite floor of lenticularis is actually a tabula. Beecher's (1893a, p. 211) studies of the development of lenticularis imply that this primitive species is nontabulate.

Occurrence.-Lower Devonian Rabbit Hill Limestone. Rabbit Hill, Copenhagen Canyon, locality M409. Dobbin Summit, Monitor Range, locality M1309 (cf.). Petes Canyon, Toquima Range, locality M1150 (cf.). Walti Ranch, Simpson Park Range, locality M1074 (cf.). Mount Tenabo, Cortez Mountains, locality M1083.

\section{Pleurodictyum dunbari n. sp. Plate 1, figures 13-15}

1963 Pleurodictyum cf. P. trifoliatum Dunbar. Merriam, p. 43.

Type material.-Holotype, USNM 159522; paratype USNM 159523. Lower Devonian Rabbit Hill Limestone, locality M409.

Diagnosis.-Stalked, elongate, simply branching Pleurodictyum with one to six thick-walled large corallites with deep calice, a central calicinal boss, and about 22 prominent pseudosepta composed of longitudinally alined spines. Peritheca thick, with a basal expanded pedal attachment.

Remarks.-The mural pores are large and serve to establish this aberrant form as a tabulate coral. A transverse thin section of the stalk $1 \mathrm{~cm}$ above the basal attachment shows parts of five closely appressed thick-walled corallites; these have about 12 thick pseudosepta or septal spines, some of which reach the center and are for the most part laterally in contact.

The thick main stalk with expanded apical (or basal) attachment appears to be that of the initial corallite from which the others have budded off, more or less in the manner described by Beecher for Pleurodictyum lenticulare (Hall) (1893a, p. 207-212, pls. 9-13), but after the primary corallite attained large size and was growing erectly from its apical attachment disc. A silicified specimen reveals no trace of tabulae in longitudinal section of the stalk, but these structures could have been destroyed by the silicification.

Pleurodictyum trifoliatum Dunbar (1920, p. 118, pl. 1, figs. 5-7) of the Lower Devonian Rockhouse Shale in Tennessee lacks the stalk and is an encrusting form, but is otherwise similar to $P$. dunbari n. sp.; somewhat closer perhaps is $P$. tennesseensis Amsden (1949, p. 100, pl. XXIII, figs. 1-3) of the Silurian Brownsport Formation, which is erect but lacks the elongate stalk.

Occurrence.-Lower Devonian Rabbit Hill Limestone. Rabbit Hill, Copenhagen Canyon, locality M409.

Order RUGOSA Edwards and Haime, 1850

Family LACCOPHYLLIDAE Grabau, 1928

Reference form-Syringaxon siluriensis (McCoy), 1850.

Small solitary trochoid to subcylindrical rugose corals with very deep calice, straight, smooth lamellar septa, a narrow septal stereozone, and tubular stereoplasmic aulos. Tabulae partly complete, very strongly uparched; nearly flat within aulos, steeply inclined peripherally. No dissepiments.

These nondissepimented, but otherwise specialized corals are distinguished by the strong inner ring produced by swelling of septal tips and commonly rather heavy addition of extraneous stereoplasm. Arching of tabulae is pronounced. The Laccophyllidae occur in the Silurian and Devonian, wherein they may be abundant in a facies lacking other Rugosa. Nearly identical small corals like Permia, reappearing in the Carboniferous, may be homeomorphic (Hudson, 1944, p. 360; Flügel and Free, 1962, p. 232). Somewhat less convergent are the Permian Polycoeliidae as revised by Schindewolf (1942, p. 55).

Syringaxon, the only member of this family recognized in the Great Basin, is the characterizing rugose coral of the Helderberg (Early Devonian) Syringaxon facies.

\section{Genus Syringaxon Lindström, 1882}

1882 Syringaxon Lindström, p. 20.

1900 Laccophyllum Simpson, p. 201.

1902 Nicholsonia Pocta, p. 184. Cited in plate explanations as Alleynia (Nicholsonia).

1928 Laccophyllum Simpson. Grabau, p. 82.

1928 Alleynia Počta ANicholsonia Počta). Grabau, p. 82

1935 Syringaxon Lindström. Butler, p. 117.

1938 Syringaxon Lindström (in part). Prantl, p. 21.

1940 Syringaxon Lindström. Lang, Smith, and Thomas, p. 129.

1949 Syringaxon Lindström. Stumm, p. 10.

1956 Syringaxon Lindström. Hill, p. F258.

1962 Syringaxon Lindström (in part). Flügel and Free, p. 224.

Type species.-By monotypy, Cyathaxonia siluriensis McCoy, 1850 (p. 281); Silurian, upper Ludlow, Underbarrow, Kendal, Westmorland, England. According to Butler (1935, p. 118) and Lang, Smith, and Thomas (1940, p. 129), Lindström, in naming the genus, gave no diagnosis, merely using McCoy's species siluriensis under the new generic name Syringaxon in his faunal lists of the Gotland Silurian (Lindström, 1882, p. 20). 
Diagnosis.-Small, solitary turbinate and ceratoid to cylindrical rugose corals with deep calice and lacking dissepiments. Axial ends of major septa dilated and laterally in contact to form an aulos. Tabulae strongly uparched distally, the aulos dividing them into inner flat or slightly sagging segments and outer segments that descend steeply to meet the outer wall (Flügel and Free, 1962, fig. 3); tabulae either continuous from wall to wall through aulos stereozone, terminating within the aulos or abutting proximally as tabellae against adjacent tabulae. Stereome usually abundant as aulos thickening and general thickening or filling in brephic and neanic growth stages. Narrow fossulae commonly reveal quadrants in late neanic growth stages.

Remarks. - The genus Laccophyllum was proposed by Simpson (1900, p. 201) with L. acuminatum Simpson from the Niagaran of Tennessee as type species. Butler's exhaustive study (1935) fixed McCoy's (1850, p. 281) "Cyathaxonia siluriensis" as the type species of Syringaxon Lindström, following which Lang, Smith, and Thomas (1940, p. 129) concluded that the holotype of Laccophyllum acuminatum Simpson is assignable to Syringaxon, making Laccophyllum Simpson a synonym of Syringaxon Lindström.

Alleynia Počta or Alleynia (Nicholsonia) Počta (Lang and others, 1940, p. 15, 129) appears to be correctly interpreted as a synonym of Syringaxon.

Barrandeophyllum Počta (1902, p. 190) resembles Syringaxon. According to Prantl (1938, p. 34), who studied Počta's cotypes of Barrandeophyllum perplexum the type species, this genus is closely related to Syringaxon. Barrandeophyllum is distinguished by irregularities of the aulos, usually elliptical in transverse section, and by a sparing development of dissepiments. Stereoplasm is always present, though not abundant. The type species of Barrandeophyllum is reported from the Early Devonian Branik Limestone of Bohemia. Syringaxon ranges from the Tennessee Niagaran through strata of Early Devonian (Helderberg) age in western North America and is reported in the Late Devonian Independence Shale of Iowa (Stainbrook, 1946, p. 402).

As noted by Hudson (1944, p. 360), small, rather simple corals resembling Syringaxon range upward to the Carboniferous, where they are represented by Permia Stuckenberg. According to Hudson, Permia and Syringaxon are homeomorphs.

Small solitary corals resembling Syringaxon occur in the Silurian part of the Hidden Valley Dolomite of the northern Panamint Mountains (McAllister, 1952, p. 15-17). Following the great proliferation of this genus in the Helderbergian of the Great Basin, it virtually disappeared from this region; scarce and fragmentary specimens that may belong either in Syringaxon or
Barrandeophyllum have been found in Nevada Formation unit 2 at Lone Mountain.

\section{Syringaxon foerstei $\mathbf{n}$. sp.}

Plate 2, figures 1-10

1963 Syringaxon acuminatum (Simpson). Merriam, p. 43.

Type material.-Holotype, USNM 159243; figured paratypes, USNM 159245-159250. Rabbit Hill Limestone, Early Devonian, Central Great Basin, Monitor Range.

Diagnosis.-Syringaxon having a very deep calice, thick wall, prominent longitudinal grooves externally and on interior of calice wall, and a high septal count for this genus. Cardinal and alar septa differentiated in neanic stages.

External features.-Corallum large for the genus, attaining a length exceeding $30 \mathrm{~mm}$ and greatest diameter of $27 \mathrm{~mm}$ at edge of calice; average length about $19 \mathrm{~mm}$ with maximum diameter $16 \mathrm{~mm}$ (see table). Calice very deep, in large individuals $16 \mathrm{~mm}$, or more than half the corallum length. Average specimen trochoid; ceratoid individuals fairly common; turbinate and nearly cylindrical individuals uncommon. Septal grooves sharply defined and distinctly pinnate with reference to the primary septa. Rugae weakly defined or absent, rarely prominent. Occasional individuals with talons or attachment surface at apex. Septa extend distally as low subequal ridges on inside of calice, rarely becoming obsolete. Aulos defined as ringshaped boss at bottom of calice in many individuals; in other specimens the aulos is ill defined and narrow fossulae may outline quadrants made by the primary septa.

Transverse sections.-Mature sections show from 26 to more than 30 major septa extending three-fourths of the distance to the axis. Minor septa normally present, but in some individuals not recognized at maturity; these septa range from mere stubs to one-third the length of major septa; in some instances, they are buried within the peripheral stereoplasm. Septa usually

Syringaxon (foerstei) n. sp. Table of measurements (in $\mathrm{mm}$ )

\begin{tabular}{|c|c|c|c|c|c|}
\hline & 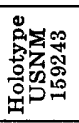 & 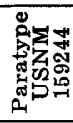 & 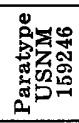 & 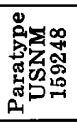 & 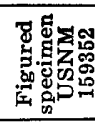 \\
\hline Restored corallum & & & & & \\
\hline length & 32 & 17 & & & \\
\hline Calice depth ......... & 16 & 8 & & & \\
\hline Outside diameter & & & & & \\
\hline bottom & 12 & 11.5 & & & \\
\hline $\begin{array}{l}\text { Number of major } \\
\text { septa at calice } \\
\text { bottom }\end{array}$ & 28 & 24 & & & \\
\hline $\begin{array}{l}\text { Ephebic section: } \\
\text { Diameter } \\
\text { Major septa }\end{array}$ & & & 26 & $\begin{array}{l}13 \\
24\end{array}$ & $\begin{array}{l}15.6 \\
26\end{array}$ \\
\hline
\end{tabular}


dilated toward tips, laterally in contact and reinforced by stereoplasm to produce an aulos. Entire septum may be somewhat dilated. Individuals with poorly defined aulos show pairs of contiguous septa meeting axially like a tuning fork, the merged segments continuing toward axis; they may reveal quadrate transverse symmetry. The peripheral stereozone may exceed $1 \mathrm{~mm}$, but it is usually not as thick as the aulos. Amount of stereoplasm varies considerably; some early ephebic sections show entire aulos filled with this material. Appearance of false dissepiments may result from section cutting bulbous distal inflations of tabulae between aulos and outer wall.

Longitudinal sections.-Outer segments of tabulae descend steeply, with upward inflection before meeting the stereozone. Some complete tabulae are vague within the aulos; others are traceable completely across. Aulos segments of tabulae may be thickened stereoplasmically. In some individuals complete tabulae have M-shape curvature with near-vertical outer segments. Tabular spacing nonuniform, usually fairly wide.

Comparison with related forms.-Butler's (1935) figures of Syringaxon siluriensis (McCoy) show a maturely cerioid to subcylindrical form with fewer septa and poorly developed minor septa. $S$. foerstei includes externally similar subcylindrical variants, but the norm is a trochoid corallum. Both species are inclined to have heavy stereoplasmic deposits in the aulos and a wide septal stereozone. Of several species figured by Prantl (1938) from the Devonian of Czechoslovakia, most have a lower septal count and elongate subcylindrical coralla. Species described from the Greifensteiner Kalk (Eifelian) of Germany by Flügel and Free (1962) have a weaker aulos and less arching of tabulae.

Occurrence.-Rabbit Hill Limestone of Helderberg (Early Devonian) age; Devonian coral zone A. Northern Monitor Range, Rabbit Hill vicinity, localities M48, M49, M187. Middle part of the Monitor Range, Dobbin Summit area, localities M1067, M1068, M1069. Northern Simpson Park Range: Walti Hot Springs area, locality M1074; Coal Canyon area, localities M1032, M1075, M1076. Cortez Mountains, Mount Tenabo area, locality M1083.

Beacon Peak Dolomite Member of Helderberg (Early Devonian) age, Devonian coral zone A. Southern Sulphur Spring Range, localities M186, M197, M1081, M1082.

Family STREPTELASMATIDAE Nicholson, 1889

Genus Siphonophrentis O'Connell, 1914

Siphonophrentis sp. B

Plate 8, figures 1-3

Fragmentary specimens of a nondissepimented coral provisionally placed in Siphonophrentis were collected from the Beacon Peak Dolomite Member in the southern Sulphur Spring Range. A silicified individual with restored corallum length of about $45 \mathrm{~mm}$ and greatest diameter of $32 \mathrm{~mm}$ has about 60 straight, tapering septa of medium length, poorly differentiated as major and minor. An indefinite fossula lies on the convex side of the corallum. The septal stereozone is narrow.

A smaller individual, possibly the tip of the above described larger corallum, has short septa, a narrow peripheral stereozone and rather close-set tabulae, part of which are complete. Large elongate tabellae are present peripherally.

Occurrence.--Southern Sulphur Spring Range, locality M186. Beacon Peak Dolomite Member of the Nevada Formation, in Devonian coral zone A with a Rabbit Hill Early Devonian (Helderbergian) fauna.

\section{Family ENDOPHYLLIDAE Torley, 1933}

Reference forms.-Endophyllum bowerbanki Edwards and Haime and E. abditum Edwards and Haime, 1851. Devonian, Torquay, England.

Cerioid and aphroid rugose corals with wide corallites, a broad marginarium of partly large lonsdaleioid dissepiments and a narrow to very wide tabularium comprising closely spaced tabulae. No axial structure.

Genera assigned to the Endophyllidae are:

Endophyllum Edwards and Haime, 1851

Yassia Jones, 1930

Australophyllum Stumm, 1949

Undescribed Late Silurian corals of the Klamath Mountains, Calif., and the Great Basin also belong in this family. These include an unnamed subgenus of Australophyllum characterizing Great Basin Silurian coral zone $\mathrm{E}$ and an unnamed genus related to Australophyllum in the Silurian Gazelle Formation of the Northeast Klamath Mountains.

Certain corals here regarded as Endophyllidae have previously been assigned to Spongophyllum, a homeomorphic genus not included in this family. It is proposed that the term Spongophyllum be applied only to species with slender corallites agreeing in general structure and proportions with the Devonian S. sedgwicki as originally illustrated by Edwards and Haime (1853, pl. 56 , figs. $2,2 \mathrm{a}-\mathrm{c}, 2 \mathrm{e}$ ).

In addition to the wide lonsdaleioid marginarium, Late Silurian representatives of Yassia and the undescribed subgenus of Australophyllum manifest a decided tendency to abbreviate and lose septa in mature growth stages, characteristics not observed in Spongophyllum.

\section{Genus Australophyllum Stumm, 1949}

1911 Spongophyllum cyathophylloides Etheridge, p. 7-8, pl. A, fig. 3, pl. C, figs. 1-2.

1949 Australophyllum Stumm, p. 34, pl. 16, figs. 1-2. 
1956 (?) Australophyllum cyathophylloides (Etheridge). Hill, fig. 207-4a-b.

Type species. - Spongophyllum cyathophylloides Etheridge, by author designation. "Lower Middle Devonian"; Douglas Creek, Clermont, Queensland, Australia.

Diagnosis.-Cerioid Endophyllidae with medium wide to narrow, closely spaced, proximally sagging tabulae and wide to very wide dissepimentarium comprising scattered to wholly lonsdaleioid dissepiments, some large.

Remarks.-Australophyllum differs from Spongophyllum by having multiple columns of elongate, lonsdaleioid dissepiments and more closely spaced sagging tabulae without peripheral depression. Stumm's diagnosis of Australophyllum includes carinate septa, although his figures do not reveal these convincingly. The wall of typical Australophyllum is thickened stereoplasmically; septal crests do not appear to be characteristic, as in the undescribed Silurian subgenus.

Australophyllum landerensis n. sp.

Plate 9, figures 3-6

Diagnosis.-Australophyllum with long minor septa, all septa thickened in tabularium and outer dissepiments steeply inclined for the genus; outer wall thickened and beaded with wall crests. Tabularium medium wide; close-set tabulae with pronounced sag.

External features.-Occurs in compact cerioid heads 6 inches or more in diameter.

Transverse sections.-Septa about 44, all of which are long and usually thickened within the tabularium; minor septa are more than one-half the length of major septa. Some major septa reach the axis, where they are twisted. Septa may be minutely wavy, and where thickened show minute nodes and lateral bumps, but no true elbow carinae. Stereome-thickened wall with beaded appearance because of wall crests; other septal crests sparse in lonsdaleioid band.

Longitudinal sections. - Tabularium about one-third the corallite width at maturity, very sharply set off from dissepimentarium. Tabulae 4 or 5 per millimeter, with pronounced sag that may be angulate axially. Large outer dissepiments steep for this genus, the smaller ones becoming vertical at tabularium margin. Dissepiment columns range from 7 to 12 . Thickened axial segments of major septa reveal minute lateral bumps.

Reproductive offsets.-One mature corallite shows three calice wall offsets internally situated.

Fine structure.-Thickened septa may have a median clear trace; trabecular structure and lamination ill defined in septal stereozone.

Comparison with related forms.-Australophyllum cyathophylloides, the type species, differs by having fewer septa that lack thickening in the tabularium. Australophyllum sp. $\mathrm{v}$ from the upper part of the Vaughn Gulch Limestone, Owens Valley, Calif., resembles Australophyllum landerensis, but lacks thickened septa; Australophyllum sp. v occurs in beds of possible Early Devonian age immediately above Late Silurian coral zone E, which contains a different subgenus of Australophyllum. The coral zone E subgenus has broader mature corallites with a considerably smaller septal count and lacks septal thickening; this form has outer lonsdaleioid dissepiments inclined at a low angle, a greater number of very large dissepiments, and, unlike $A$. landerensis, tends to reduce and lose septa at maturity.

Measurements.-Mature corallite diameter and major septum count:

Diameter (in mm) ........ Major septa

\begin{tabular}{ccc}
\multicolumn{3}{c}{ Holotype } \\
USNM 159353 \\
\multicolumn{3}{c}{ corallites } \\
A & B & C \\
13 & 14 & 10 \\
22 & 22 & 22
\end{tabular}

Paratype

USNM 159354 corallites

$13 \quad 10$

$20 \quad 22$
Occurrence.-Lower Devonian Rabbit Hill Limestone, Petes Canyon, locality M1150 at north end of Toquima Range, southern Lander County. At locality M1150 this colonial coral is associated with a typical Rabbit Hill fauna like that of the type locality. Colonial corals of this kind are uncommon in the Rabbit Hill, which usually contains only the small solitary rugose coral Syringaxon.

\section{Australophyllum stevensi n. sp. Plate 9, figures 8-13}

Type material.-Holotype, USNM 165349; Sunday Canyon Formation, locality M1401.

Diagnosis.-Australophyllum with few lonsdaleioid dissepiments, many small dissepiments, septal thickening in tabularium moderate and nonuniform. Minute septal spines present.

Transverse thin sections.- Septal count about 42 in a corallite of $13 \mathrm{~mm}$ diameter; longer septa minutely wavy and twisted near axis. Minor septa two-thirds length of major septa. Carinae absent. Septa moderately to slightly thickened in tabularium and innermost dissepimentarium of parts of some corallites. Wall moderately thickened stereoplasmically. Lonsdaleioid septa present in some corallites, where they are irregular and confined to small segments.

Longitudinal thin sections.-Tabularium medium wide to wide; tabulae close spaced and sagging. Dissepiments mostly small, with as many as eight columns on each side, many steeply inclined. Minute septal spines scattered. 
Comparison with related forms.-Australophyllum stevensi differs from $A$. landerensis by having fewer and less uniformly developed lonsdaleioid dissepiments, a less thickened wall, and less extensive septal thickening. The minute septal spines of $A$. stevensi were not observed in A. landerensis. Australophyllum $\mathrm{sp} . \mathrm{v}$ of the higher Vaughn Gulch Limestone differs by having unthickened septa and a somewhat more uniform pattern of lonsdaleioid dissepiments.

Occurrence.-Sunday Canyon Formation (Ross, 1966, p. 32), Mazourka Canyon area, northern Inyo Mountains, Calif., locality M1401, east side of Al Rose Canyon. The Sunday Canyon Formation as demonstrated by Ross passes southward into the Vaughn Gulch Limestone. A. stevensi came from beds that may be of Early Devonian age about 40 feet stratigraphically below the top of the Sunday Canyon.

Study material is part of a single large corallum.

\section{Australophyllum sp. $\mathbf{v}$}

Plate 9, figure 7

Australophyllum sp. v. represented by a fragmentary corallum from the upper part of the Vaughn Gulch Limestone of the northern Inyo Mountains, Calif., shares some features of $A$. landerensis of the Rabbit Hill and some characteristics of $A$. stevensi of the Sunday Canyon Formation.

Australophyllum sp. v has the thickened wall of $A$. landerensis, but its septa are unthickened. The lonsdaleioid band is somewhat better developed than in $A$. stevensi, and its septa are peripherally discontinuous as septal crests.

Occurrence.-Upper part of the Vaughn Gulch Limestone, Mazourka Canyon area, northern Inyo Mountains, Calif., locality M1093. The Vaughn Gulch Limestone (Ross, 1966, p. 30) is largely Silurian, but its upper unit is possibly of Early Devonian age like the upper part of the Sunday Canyon Formation, which passes laterally into the Vaughn Gulch beds. Late Silurian limestones of coral zone E underlie the beds that yielded Australophyllum sp. v.

\section{Family DISPHYLIIDAE Hill, 1939 \\ Genus Billingsastraea Grabau, 1917 \\ Billingsastraea sp. $\mathrm{m}$ \\ Plate 9, figures 1, 2}

Figured material.-Specimen USNM 165350; southern Tuscarora Mountains, Maggie Creek, locality M1400.

Diagnosis.-Billingsastraea with unusually small corallites for the genus and smooth uniformly unthickened septa.

Transverse thin sections.-Septal count about 35 in a corallite of $71 / 2 \mathrm{~mm}$ diameter; septa smooth, uniform and unthickened, the major septa extending to axis; minor septa more than three-fourths length of major septa. Septa slightly wavy only in tabularium. Small dissepiments crowded at inner edge of dissepimentarium.

Longitudinal thin section.-Only available section does not pass through tabularium. Some flat dissepiments very elongate.

Comparison with related forms.-Corallites of this species are about one-half the width of those of $B$. nevadensis (Stumm) and B. affinis (Billings), both of which have a larger septal count and minutely wavy septa with small zigzag carinae not present in Billingsastraea sp. m.

Occurrence.-South end of the Tuscarora Mountains, locality M1400 near Maggie Creek northwest of Carlin. This coral is associated with a Rabbit Hill Early Devonian fauna, and appears to be the oldest known occurrence of Billingsastraea.

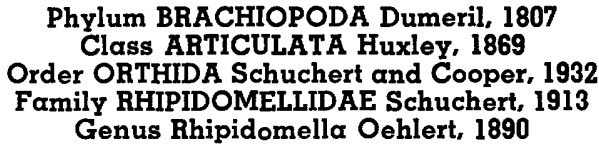

1958 Rhipidomelloides Boucot and Amsden, p. 165, pl. XII, figs. 5-9, pl. XIV, figs. 10-11, text figs. 9, 42.

The Rabbit Hill brachiopods placed in Rhipidomella are most similar to species previously classified by Boucot and Amsden (1958) as "Rhipidomelloides," a genus later placed in synonymy (Williams and Wright, 1965, p. 341).

\section{Rhipidomella rossi n. sp. \\ Plate 4, figures 15-24}

1963 Dalmanella sp. (small form); Merriam, p. 43.

Type material.-Holotype, USNM 159556; paratypes, USNM 159555, 159557-159561. Rabbit Hill Limestone, locality M409.

Diagnosis.-Orthoid brachiopods with dorsal and ventral valves about equally convex, rectimarginate; dorsal valve without sulcus. Ventral valve muscle field moderately large, ovoid-fan-shaped, and lacking the radial myophragms of some $R$ hipidomella. Dorsal valve with stout brachiophores and large thickened cardinal process.

Exterior.-Outline ovoidal to subcircular. Hinge line about one-half maximum width of shell. Pedicle valve interarea curved, concave, slightly apsacline, much longer than dorsal valve interarea. Delthyrium large and open. Both valves flattened toward commisure; without trace of sulcus or fold. Fine radial ribs split anteriorly.

Pedicle valve interior.-Delthyrial cavity large and deep; teeth large, supported by abbreviated but stout dental plates. The muscle field is bilobed, rounded anteriorly, and has a median septum which is promi- 
nent anteriorly at the union of the two large crescentic diductor scars and faint or nonexistent posteriorly between the adductors. The more or less heart-shaped combined adductor areas are relatively large for the genus. Radiating myophragms that divide the muscle field of some Rhipidomella species were unrecognized. No pallial markings were observed. Crenulations at internal shell margin reported (Boucot and Amsden, 1958$, p. 165,168$)$ to characterize "Rhipidomelloides" are too poorly preserved for meaningful comment. Where recognizable on the silicified shells, they are more suggestive of those of Rhipidomella than those of rectangular cross section in "Rhipidomelloides."

Brachial valve interior.-Median ridge varies from very heavy to rather faint; extends to middle of valve. Transverse ridge separating anterior from posterior adductor scars well defined to faint; anterior scar is larger. Stout shaft of cardinal process simple, may be constricted beneath myophore that has one to several tubercles.

Comparison with related forms.-Rhipidomella rossi appears to be related to both $R$. oblata (Hall) of the Haragan Limestone and $R$. henryhousensis Amsden of the Henryhouse Formation (Boucot and Amsden, 1958, pl. II, figs. 1-16; pl. XII, figs. 1-9; pl. $\mathrm{XIV}$, figs. 10-11). $R$. rossi seems to be more nearly equivalved in transverse profile than oblata; the brachiophores and cardinal process of henryhousensis are less stout. Some specimens of oblata have well-defined radiating myophragms in the ventral-valve muscle field not noted in rossi, and the cardinalia of oblata are less heavy.

Occurrence.-Lower Devonian Rabbit Hill Limestone. Rabbit Hill, Copenhagen Canyon, locality M409.

Family DALMANELLIDAE Schuchert, 1913 Genus Levenea Schuchert and Cooper, 1931

1931 Levenea Schuchert and Cooper, p. 246.

1932 Levenea Schuchert and Cooper, p. 123, pl. 18, figs. 19-23., 25-32.

Type species.-Orthis subcarinata Hall, 1857 (by author designation). Early Devonian (Helderbergian); New York and Tennessee.

Diagnosis.-Dalmanellid brachiopods with subcircular outline, hinge line narrower than greatest width, ventral interarea longer than dorsal; delthyrial cavity of ventral valve deep, dental plates thickened on inside to form fossette, diductor tracks deeply impressed. Cardinal process prominent with lobate myophore; adductor field or dorsal valve subcircular, or elliptical.

This genus, though reported from the Silurian, is especially characteristic of the Early Devonian (Helderberg) rocks.
Levenea subcarinata subsp. antelopensis n. subsp.

Plate 4, figures 1-14

1963 Levenea n. sp. cf. L. subcarinata (Hall). Merriam, p. 43.

Type material.-Holotype, USNM 159547; paratypes, USNM 159548, 159551, 159552, locality M409. Paratypes, USNM 159549, 159550, locality M186. Paratype, USNM 159553, locality M1309. Paratype, USNM 159554, locality M1312. Rabbit Hill Limestone and Beacon Peak Dolomite Member of the Nevada Formation.

Diagnosis.-Large unequally biconvex Levenea with well-defined brachial valve sulcus and medially subcarinate pedicle valve. Brachiophore blades thick. Adductor scars of brachial valve large and deeply impressed on shelly platform with medial ridge. Cardinal process elongate and narrow to large with swollen bifid termination at myophore.

Pedicle valve interior.-Delthyrial cavity deep; diductor tracks deeply impressed in thickened shell platform and separated by a wide flat-topped ridge which may have a median groove. Diductor and adjustor scars not differentiated. Teeth stout; dental plates short and merging with anteriorly projecting wall of delthyrial cavity. Dental plates may be thickened on medial side above umbonally directed grooves in wall of delthyrial cavity. Large rounded pit may develop just anterior to muscle platform. Pallial markings not well defined.

Brachial valve interior.-The large subquadrate, quadripartite muscle field is sharply impressed in a thickened shelly platform having prominent raised rim; the median dividing ridge is usually stout and rounded from the cardinal process shaft through the posterior adductor pair, becoming more narrowly carinate anteriorly. Brachiophores are thick blades joining the raised outer muscle field rim dorsally. Sockets deep and rounded. In some individuals there is a weakly defined transverse lateral groove, the prolongation of that between anterior and posterior adductor scars.

External features.-Subcarinate pedicle valve much more deeply convex than sulcate brachial valve in this biconvex shell. Valves ornamented by fine, close-set, more or less equal radial costellae that split anteriorly. Outline subrounded in commissure plane, greatest width anterior to hinge line.

Comparison with related forms.-Within its variation range, subsp. antelopensis includes individuals whose brachial interior features may be matched closely with those of typical subcarinata as figured by Schuchert and Cooper (1932, pl. 18, figs. 19, 25, 31, 32), and in general the new subspecies is morphologically quite similar to the eastern Helderberg species. Typi- 
cal subcarinata, unlike subsp. antelopensis, seemingly does not have a marked tendency toward bifurcation of the cardinal process, whereas antelopensis lacks the secondary shaft of the cardinal process over the median ridge (Schuchert and Cooper, 1932, p. 124) shown by subcarinata s.s.

Occurrence.-Early Devonian Rabbit Hill Limestone. Rabbit Hill, Copenhagen Canyon, locality M409. Dobbin Summit, Monitor Range, localities M1309, M1311. Petes Canyon area, Toquima Range, locality M1150. Coal Canyon, Simpson Park Range, locality M1075. Early Devonian Beacon Peak Dolomite Member. Southern Sulphur Spring Range, localities M186, M197, M1312.

Family ORTHIDAE Woodword, 1852
Genus Orthostrophia Hall, 1883
Orthostrophia strophomenoides subsp. newberryi n. subsp.
Plate 3, figures 4, 5; plate 8, figures 6-9
1963 Orthostrophia sp. cf. O. strophomenoides (Hall), Mer-
riam, p. 43.
Type material.-Holotype, USNM 159540; para-
types, USNM 159616, 159617. Rabbit Hill Limestone,
locality M409.

Diagnosis.-Orthostrophia of the strophomenoides (Hall) type, large for the genus, with transverse outline, ventral fold, and dorsal sulcus. Sulcus well developed on posterior half only, becoming obsolete toward the commissure in mature shells. Strength of radial ornamentation medium to coarse for the genus. Dental plates abbreviated as anterolateral rims of delthyrial cavity.

External features.-Shell with biconvex lateral profile; outline transverse-subquadrate. Hinge line wide and straight. Ventral interarea apsacline, longer than dorsal interarea, which is orthocline. Ornamentation multicostellate with heavier radial ribs rather coarse for the genus (5-7 ribs within $6 \mathrm{~mm}$ on mature part). Concentric incremental ridges widely spaced and rather subdued.

Pedicle valve interior.-Muscle field small, of triangular outline, deeply impressed and terminating anteriorly as an elevated shelf. The dental lamellae develop as abbreviated anterolateral rims of the delthyrial cavity. Pallial markings and margins of adductor and diductor scars indefinite on available silicified specimens.

Brachial valve interior.-Brachiophores moderately thick at edge of wide and fairly deep notothyrial cavity. Sockets small. Cardinal process simple, swelling anteriorly to merge with prominent rounded medial ridge that divides the muscle field. Adductor muscle scars deeply impressed on a raised shelly platform. Transverse ridges separating anterior from posterior adduc- tor scars weakly developed. Pallial markings poorly shown.

Comparison with related forms.-Orthostrophia strophomenoides newberryi resembles $O$. strophomenoides (Hall) quite closely, judged by the illustrations of Schuchert and Cooper (1932, p. 70-71, pl. 6, figs. 22, $24,25,27,28)$ and of Hall and Clarke (1892, pt. 1, pl. V, figs. 24-27). The hinge plate and brachial valve muscle scar features are similar, but the available specimens of newberryi do not reveal the strong pallial markings of typical strophomenoides and the costellae of newberryi seem on the whole slightly heavier.

Orthostrophia strophomenoides subsp. parva Amsden (1958a, p. 41-45, pl. 1, figs. 22-32) seems to be a smaller subspecies, with somewhat less coarse radial costellae than subsp. newberryi. Amsden's illustrations (1958a, pl. 1, fig. 30, 31, 32) show a better separation of anterior from posterior adductor scars of the brachial valve than in newberryi and strongly developed vascular markings not known in the new species, possibly because of preservation by silicification.

Occurrence.-Early Devonian Rabbit Hill Limestone. Rabbit Hill, Copenhagen Canyon, locality M409.

\footnotetext{
Order STROPHOMENIDA Öpik, 1934

Family STROPHEODONTIDAE Caster, 1939

Genus Leptostrophia Hall and Clarke, 1892

Leptostrophia sp. cf. L. becki tennesseensis Dunbar

Plate 3, figures 1-3; plate 8 , figure 5
}

Fragmentary ventral valves of this genus from the Rabbit Hill type section reveal interior details and surface ornamentation. Ventral interiors have large triangular diductor scars with bounding lateral ridges; the ventral process is large and where widest shows a median groove. Externally the ventral valve is slightly convex near the umbo, flattening laterally and anteriorly. The surface is finely costellate, with about eleven costellae per width of $5 \mathrm{~mm}$. Concentric rugae weak, recognizable only about halfway between umbo and shell perimeter.

The Rabbit Hill shells resemble specimens from the Bois d'Arc Limestone of Oklahoma and from the Birdsong Shale of Tennessee referred by Amsden (1958a, p. $78-80$; pl. 3 , figs. $15-20$; pl. 6 , fig. 1 ; pl. 11, figs. 27 , $28)$ to this subspecies. Those illustrated by Amsden are much less strongly rugate concentrically than the possibly aberrant representative of tennesseensis described and figured by Dunbar (1920, p. 129, pl. 3, fig. 18).

The Rabbit Hill Leptostrophia resembles more completely an undescribed species from the lower part of the Nevada Formation (unit 1), where it occurs in post-Rabbit Hill beds of Oriskany age. This form has a less expanded ventral process with a less conspicuous median groove. 
Occurrence.-Lower Devonian Rabbit Hill Limestone. Rabbit Hill, Copenhagen Canyon, locality M409. Dobbin Summit, Monitor Range, locality M1309.

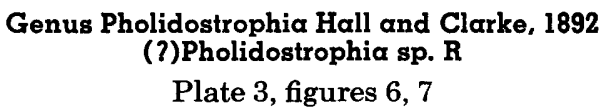

This distinctive, possibly aberrant, stropheodont is represented in the collections by a single silicified pedicle valve. The outer surface is smooth and without pseudonacreous texture, probably because of replacement by siliceous matter. This valve is deeply convex, with greatest width near hinge line; interarea wide, short, orthocline, and denticulate. The poorly preserved pseudodeltidium is thick, largely closing the delthyrium, and probably had a median fold.

The muscle field is rather deeply impressed; the large fan-shaped diductor scars, unlike normal Pholidostrophia, have strong lateral bounding ridges. Cardinal process receiving pits are large and deep, suggesting that the cardinal process of the brachial was thick. A long ventral process is split by a median groove throughout, this groove extending almost to the anterior shell margin. Adductor scars unusually large and oval. Pseudoteeth present.

This form differs markedly from normal Pholidostrophia by having diductor scar bounding ridges and a very elongate median groove of the ventral process. It may represent a distinct genus, but fuller characterization must await collecting of more material.

Occurrence.-Lower Devonian Rabbit Hill Limestone. Rabbit Hill, Copenhagen Canyon, locality M409.

\section{Genus Strophonella Hall, 1879 Strophonella cf. S. punctulifera (Conrad) Plate 3, figures 10, 11}

A large Strophonella with exterior features intermediate between $S$. punctulifera and $S$. bransoni Amsden occurs at several localities in the southern Sulphur Spring Mountains in association with Rabbit Hill Helderberg species. The resupinate curvature is within the range of that illustrated by Amsden (1958a, p. 70) for bransoni, but the radial ornamentation is perhaps more like that of the New York Helderberg punctulifera (Hall and Clarke, 1892, pl. XII, fig. 10), which reveals finer costellae than the Haragan species bransoni.

Strophonella has been recognized only in the Lower Devonian of Nevada, where two other forms occur in Nevada Formation, unit 1; of these, one occurs in the Oriskany age beds of coral zone $\mathrm{B}$ and another slightly higher in the beds of coral zone $\mathrm{C}$ together with Papiliophyllum and Acrospirifer kobehana.

This genus was not found in limestone facies of the typical Rabbit Hill Limestone.

Occurrence.-Lower Devonian, Beacon Peak Dolo- mite Member of the Nevada Formation. Southern Sulphur Spring Range, localities M186, M197, M1081.

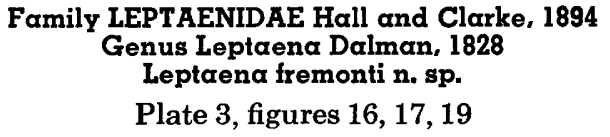

1963 Leptaena sp. cf. L. rhomboidalis (Wilckens). Merriam, p. 43.

Type material.-Holotype, USNM 159544; paratype, USNM 159545. Rabbit Hill Limestone, locality M409.

Diagnosis.-Medium-sized Leptaena with fairly regular transversely subquadrate, moderately alate outline. Valves sharply geniculate anteriorly; externally the valves have few medium to heavy concentric rugae for the genus. Radial costellae may be subdued.

External features.-Proportions and outline of this slightly alate, but not strongly mucronate shell, are characteristic. The trail bears only radial ornamentation; ribs are coarse on the interior of both dorsal and ventral valve trail surfaces. Concentric rugae of pedicle valve exterior range from 6 to 9 , few for this genus when mature. The trail is usually long, fairly even, and bends abruptly almost $90^{\circ}$, as shown on pedicle valve exterior.

Pedicle valve interior.-Muscle field deeply impressed, with evenly rounded raised rim and median septum; configuration like that of many species of Leptaena.

Brachial valve interior.-Lobes of the bifid cardinal process of medium to large size, with extensive ovoidtriangular myophore surfaces. Median ridge between adductor scars may extend beyond valve middle as a weak septum. Broadened radial ribs prominent on inner trail surface. Inner valve surface may be strongly postulose.

Comparison with related forms.-Leptaena fremonti resembles Leptaena cf. L. rhomboidalis (Wilckens) of Amsden (1958c, pl. II, figs. 12-15) from the Bois d'Arc Limestone of Oklahoma, which has a more irregular outline. Leptaena acuticuspidata Amsden of the Oklahoma Haragan (Amsden 1958a, pl. III, figs. 1-9) is also similar, but shows greater irregularities in and around the muscle field of both valves. Leptaena ventricosa (Hall) from the Frisco Limestone of Oklahoma as figured by Amsden and Ventress (1963, pl. II, figs. 9-14) is more elongate, less alate, and has a larger number of concentric rugae.

Occurrence.-Lower Devonian Rabbit Hill Limestone. Rabbit Hill, Copenhagen Canyon, locality M409. Dobbin Summit, Monitor Range, locality M1311. Coal Canyon, Simpson Park Range, locality M1075. Specimens compared to this species occur in the Southern Sulphur Spring Range in the Beacon Peak Dolomite at locality M197. 
Family SCHUCHERTELLIDAE Williams, 1953

Genus Schuchertella Girty, 1904

Schuchertella cf. S. haraganensis Amsden

Plate 3, figures 12-15

1963 Schuchertella sp. (large form). Merriam, p. 43.

The genus Schuchertella is represented in the Rabbit Hill collections by several silicified pedicle valves resembling that of $S$. haraganensis; these are of medium to large size for the genus, rather coarse ribbed and lack dental lamellae. With the larger shells, the valve is nearly flat or shallowly convex; the stout hinge teeth are buttressed by a thickened ridge beneath the palintrope, but not projecting anteriorly along the floor as dental lamellae. One smaller deformed individual is much more convex and narrower at the hinge line, has more elongate interarea, and shows evidence of possible beak attachment (Stehli, 1954, p. 298).

Pedicle valves of the Rabbit Hill Schuchertella have coarser ribbing than $S$. nevadensis Merriam from Nevada Formation unit 2. An undescribed species resembling nevadensis occurs in Nevada unit 1 with Acrospirifer kobehana; this undescribed form has incipient but very short dental lamellae in most but not all individuals and accordingly might be assignable to Schellwienella Thomas, rather than to Schuchertella (Amsden, 1958a, p. 90-91).

Occurrence.-Lower Devonian Rabbit Hill Limestone. Rabbit Hill, Copenhagen Canyon, locality M409. A similar Schuchertella occurs in these beds at Dobbin Summit, Monitor Range, locality M1311.

\section{Order PENTAMERIDA Schuchert and Cooper, 1931 Family PARASTROPHINIDAE Ulrich and Cooper, 1938 Genus Anastrophia Hall, 1867 \\ Anastrophia cf. A. verneuili (Hall) \\ Plate 5, figures 15-19}

Several brachial valves of a possible new species of Anastrophia were collected in the southern Sulphur Spring Range at localities M186 and M197 in association with a fairly large fauna of Rabbit Hill Helderberg age. No pedicle valves were found. The internal features of these shells are quite similar to those of verneuili as illustrated by Schuchert and Cooper (1932, pl. 25, figs. $33,36,38,39$ ).

The Nevada species is of medium size to large, with coarse radial costae and deeply convex brachial valve; the fold is weakly defined in some individuals, well defined in others. On the anterior part of large mature shells, the number of costae occuping the fold ranges from 5 to 7 . The radial ornamentation of this form also resembles that of Anastrophia grossa Amsden (1958a, p. 65-68, pl. II, figs. 18-28).

Presence of Anastrophia is significant in fixing the Helderbergian age of this fauna, because as in the New York area, this genus is not known above that interval
(Amsden, in Amsden and Ventress, 1963, p. 194; text figs. 10, 51).

Occurrence.-Lower Devonian Beacon Peak Dolomite Member of the Nevada Formation. Southern Sulphur Spring Range, localities M186 and M197.

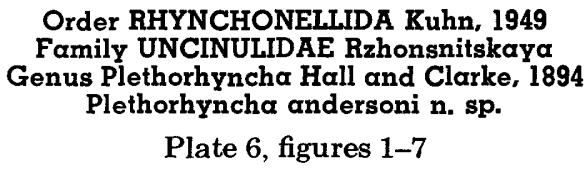

Type material.-Holotype, USNM 159574; paratypes, USNM 159575-159578. Rabbit Hill Limestone, locality M409.

Diagnosis.-Large Camarotoechiacea with broad shallow fold and sulcus; brachial valve more convex than pedicle valve. No dental plates. Rather small posteriorly situated pedicle valve muscle field. Brachial valve hinge plate (septalium) with median triangular pit bordered by adventitious thickenings.

External features.-Lateral profile biconvex; brachial valve with greater convexity. Shape transversely elliptical to subquadrate. Fold and sulcus broad and flatly rounded at commissure of mature shells; width one-half that of valves; these features developed only in anterior half of mature individuals. Pedicle valve flattened posteriorly. Shells ornamented by medium to fine subequal radial ribs, of which there are 8-12 in the sulcus at commissure of large individuals. Beaks small and subdued.

Pedicle valve interior.-Hinge narrow; teeth are modifications of wall and without dental plates. No deltidium covering recognized. Muscle field rather small, moderately impressed and flabellate, with thin median partition posteriorly; adductor scars partly differentiated. Pallial markings indistinct.

Brachial valve interior.-Hinge plate and prominent median septum united as a continuous element (septalium). The hinge plate is thickened laterally to form rims or ventral socket plates and has a triangular median pit with lateral thickenings. In available specimens there is no indication of a cardinal process or myophore. The median septum extends about one-half the distance to the anterior edge of the shell.

Comparison with related forms.-Plethorhyncha andersoni differs from $P$. speciosum (Hall), the type species (Amsden and Ventress, 1963, p. 94), by having more numerous and finer radial ribs and a well-defined fold and sulcus, these last being poorly developed in speciosum. $P$. speciosum is more elongate anteroposteriorly. The hinge plate of some individuals of speciosum carries a bifid cardinal process, although young specimens are reported to lack this structure (Amsden and Ventress, 1963, p. 95), in this respect resembling our specimens of andersoni. Havlicek (1961, p. 127-131) 
calls attention to progressive filling of the pit ("Septaliumhölung") during ontogeny by shell material. It is possible that such a filling, together with the bifid cardinal process and myophore, were destroyed in our silicified specimens of andersoni, leaving only the pit.

Most species previously assigned to Plethorhyncha such as P.? welleri -(Stewart), P.? salinensis (Stewart), and $P$. barrandi (Hall) have, like speciosum (Hall), a coarser pattern of radial ribbing (see Amsden and Ventress, 1963, pls. III and XII). Such a pattern is present in the foreign species $P$. diana (Barrande) and P. altera Barrande as figured by Havlicek (1961, pls. XV and XVI). Actually the surface ornamentation of $P$. andersoni is somewhat more suggestive of species placed in Uncinulus and Costellirostra than Plethorhyncha (see Amsden and Ventress, 1963, pl. III; Schmidt, 1941, pl. 1; Havlicek, 1961, pl. XXII), but the marked differences in internal structure do not support a direct relation. For example, Uncinulus as established by Schmidt (1941, p. 15-25) and by Havlicek (1961, p. 139-149) has in the mature growth stages a comblike structure (Havlicek, 1961, p. 142, p. 56) that develops medially on the ventral surface of the hinge plate, a feature not known in Plethorhyncha.

Occurrence.-Lower Devonian Rabbit Hill Limestone. Rabbit Hill, Copenhagen Canyon, locality M409. Dobbin Summit, Monitor Range, locality M1311. Coal Canyon, Simpson Park Range, locality M1075.

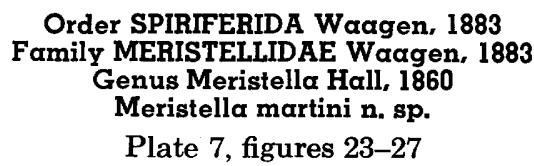

1940 (?) Meristella cf. robertsensis Merriam, pl. 6, figs. 13-16.

Type material.-Holotype, USNM 159606; paratypes, USNM 159607, 159608. Rabbit Hill Limestone, locality M409.

Diagnosis.-Of small to medium size. Outline of pedicle valve umbo acutely angulate posteriorly; curvature of wings in plane of commissure rather abrupt for the genus. Lateral surfaces of pedicle valve slope steeply just anterior to foramen and are not flattened toward hinge line as a false interarea. Pedicle beak not abruptly incurved or hooked.

External features.-Shell smooth except for concentric incremental lines that are conspicuous only toward front of mature individuals. Lateral profile subsequally biconvex; some individuals have a deeper brachial valve with convexity exceeding that of pedicle valve. Steep sides are characteristic, pitching abruptly in front of an acutely angulate pedicle valve beak. Outline in commissure plane more subtriangulate than subrounded, with abrupt curvature at greatest shell width, which is commonly anterior to middle. Brachial valve fold only near front of mature shells, where it is evenly rounded or slightly angulate at commissure. Pedicle valve sulcus only on anterior third of valve, where it is shallow except near commissure of larger individuals. Ventral valve beak prominent for genus, but not hooked anteriorly.

Pedicle valve interior.-Muscle field wide, striated, and deeply impressed for this genus. Teeth large and posteriorly hooked. Mature shells with dental plates developed as short inconspicuous ridges which are suppressed with umbonal thickening.

Brachial valve interior.-Hinge plate triangular, merging in front with a high, sharp median septum which usually extends more than one-half the valve length. Socket large. The brachiophores converge toward the beak outlining the large median triangular pit characteristic of Meristella. Some specimens reveal a process or thickening toward the apex that may be cardinal process myophore. Others have bilobed shelly fillings toward broader edge of pit, whereas some have pit filled by shelly material.

Comparison with related forms.-Meristella $\mathrm{n}$. sp. differs from Meristella robertsensis in shape and proportions of the pedicle valve, especially that part just anterior to the beak; $M$. robertsensis is also a larger form. Individuals figured by Merriam (1940, pl. 6, figs. 13-16) from Oriskany beds in the Lower Devonian of a horizon lower than those yielding the typical robertsensis are quite similar to the new species and may be assignable to it (see also Cooper, 1944, pl. 127, figs. 24, 25, but not fig. 23). Meristella atoka Girty (Amsden 1958a, pl. X, figs. 1-15) is similar to martini but appears to differ in details of the hinge plate and includes numerous variants with acute fold and sulcus at the commissure. Meristella arcuata Hall and $M$. laevis Hall are similar externally, but too little is known of the internal features of these two species to make comparison meaningful.

Occurrence.-Lower Devonian Rabbit Hill Limestone. Rabbit Hill, Copenhagen Canyon, locality M409. Dobbin Summit, Monitor Range, locality M1311. Coal Canyon, Simpson Park Range, locality M1075.

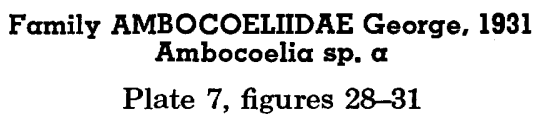

Figured material.-USNM 159609-159612; Rabbit Hill, Copenhagen Canyon, locality M409.

Several pedicle valves of Ambocoelia from the Rabbit Hill type section are of special interest in supporting the Devonian age of this formation, as the genus is unknown in older rocks.

The pedicle valve resembles that of $A$. umbonata (Conrad), the type species, by having prominent 
thickened hinge teeth unsupported by dental plates. However, the teeth are buttressed by a shelly thickening beneath the delthyrium margin that merges toward the beak with extensive umbonal filling by shell material. The sulcus is broad and shallow for the genus.

Occurrence.-Rabbit Hill Limestone. Rabbit Hill, Copenhagen Canyon, locality M409.

\section{Family LEPTOCOELIIDAE Boucot and Gill, 1956 \\ Genus Leptocoelia Hall, 1857 \\ Leptocoelia occidentalis n. sp. \\ Plate 5, figures 1-14}

1963 Anoplotheca sp. cf. A. acutiplicata (Conrad). Merriam, p. 43.

1964 (?) Leptocoelia sp. Boucot, Johnson, and Staton, pl. 125, fig. 19.

Type material.-Holotype, USNM 159562; paratypes, USNM 159563, 159565-159570, locality M409. Paratype, USNM 159564, locality M197.

Diagnosis.-Thick-shelled Leptocoelia with biconvex lateral profile and well-defined sulcus and fold. Hinge plate and cardinal process massive. Older shells have prominent pit just anterior to strongly impressed muscle field of pedicle valve.

External features.-Size, medium to large for this genus; 3 or 4 prominent, rather sharply rounded radial costae lateral to the brachial fold and 3 or 4 lateral to the strong rib defining the pedicle valve sulcus. Outline nearly round, with subdued beaks. Hinge line narrow. The two strongest costea, which occupy the fold, rise above the lateral rib as they approach the commissure; fold not defined on posterior half of valve. Pedicle valve with strong median rib in sulcus, opposing interspace between the pair of fold ribs. Concentric incremental frills strong and closely spaced toward commissure of mature shells.

Pedicle valve interior.-Hinge teeth large, separated from lateral walls by a rounded groove. Muscle field large, fan shaped, and rather deeply impressed. Pair of small ovoidal adductor scars separated by a narrow ridge that thickens posteriorly. The usually large rimmed pit in front of muscle field is distinctive.

Brachial valve interior.-Hinge plate broad and thick, brachiophores merging basally with strong ventral socket ridges that converge posteriorly at edge of plate. Cardinal process thick and elongate-triangular in outline with long, dorsally inclined posterior grooves constituting the myophore. Heavy median ridge extends anteriorly from hinge plate, narrowing to form dividing ridge of the large anterior adductor scars. Sockets large and ovoidal.

Comparison with related forms.-Leptocoelia flabellites (Conrad) Hall is regarded as the type species (Amsden and Ventress, 1963, p. 178). The new species differs from $L$. flabellites by having a highly convex brachial valve, whereas that of the former is flat; there are also marked differences in hinge-plate structure. Leptocoelia acutiplicata (Conrad) as figured by Kindle (1912, pl. VI, figs. 1-15) is much less convex than occidentalis and differs in hinge-plate structure. Leptocoelia infrequens (Walcott) is externally the closest to occidentalis, but is less convex; its internal features are not well enough known to make further comparison possible (Amos and Boucot, 1963, pl. 63, figs. 5-9). Leptocoelia occidentalis resembles species assigned to Australocoelia Boucot and Gill, 1956, but differs with respect to internal features, especially the cardinal process by which the genus is distinguished from the externally homeomorphic Leptocoelia (Boucot and Gill, 1956, p. 1174).

Leptocoelia sp. (Boucot and others, 1964, pl. 125, fig. 19) from lower beds of the Nevada Formation is a brachial valve whose interior is quite similar to that of occidentalis in nearly all structural details.

Occurrence.-Lower Devonian Rabbit Hill Limestone. Rabbit Hill, Copenhagen Canyon, locality M409. Dobbin Summit, Monitor Range, locality M1311. Walti Ranch, Simpson Park Range, locality M1074 (cf. occidentalis). Beacon Peak Dolomite Member of the Nevada Formation. Southern Sulphur Spring Range, localities M186, M197.

\section{Family RETZIIDAE Waagen, 1883 \\ Genus Trematospira Hall, 1859 \\ Trematospira mcbridei n. sp. \\ Plate 6, figures 8-15}

1963 Trematospira sp. cf. T. equistriata Hall and Clarke. Merriam, p. 43.

Type material.-Holotype, USNM 159579; paratypes, USNM 159580-159585. Rabbit Hill Limestone, locality M409.

Diagnosis.-Finely, uniformly ribbed Trematospira with well-developed sulcus; dorsal fold absent or very weakly defined. Pedicle valve with narrowly flabellate rather deeply impressed muscle field. Hinge plate subquadrate, thick and prominent, projecting about $2 \mathrm{~mm}$ posteriorly beyond beak. Sockets large.

External features.-Shape transversely elliptical, with small subdued beaks. Lateral profile moderately biconvex; hinge line narrow. No interareas. The sulcus begins near the beak, remains shallow and fairly broad to commissure of larger shells. Brachial valve convexity changes anteriorly with slight medial swelling toward front, but usually without development of a discrete fold. Radial ribs close spaced, subequal, evenly rounded, separated by interspaces of comparable width. Splitting of ribs anteriorly uncommon. Concentric striations inconspicuous. About 9 radial ribs in sulcus of pedicle valve, with 18 to 21 ribs on each flank. 
Pedicle valve interior.-Dental plates short and inconspicuous. Muscle field triangularly flabellate and rather deep, especially where its acute apex is impressed medially in floor of delthyrial cavity, forming wide lateral shelves. Adductor scars not differentiated. Pallial markings unrecognized.

Brachial valve interior.-Thickened hinge plate variable, invariably projects prominently beyond valve edge in a posterior direction; this plate is a paired structure including stout brachiophores that merge anterodorsally with thick socket plates or brachiophore support plates. The medial ridge may be either strong, tapering anteriorly from the brachiophores along the valve inner surface as a ridge, or subdued and narrow. The cardinal process is a somewhat indefinite feature without a well-defined shaft and is bordered laterally by two posterior brachiophore projections.

Comparison with related forms.-Externally T. mcbridei bears strong resemblance to T. equistriata Hall and Clarke 1894, especially as figured by Schuchert (Schuchert and Maynard, 1913, p. 430, pl. 73, figs. 8-9). The interior of equistriata is unknown but may be related to $T$. deweyi (Hall) assigned by Hall and Clarke (1894, p. 128, pl. 49, figs. 40-46) to Parazyga, the interior of which has been figured. The hinge plate of deweyi is similar to that of some individuals of mcbridei, although this structure is quite variable. Trematospira multistriata Hall has heavier radial ribbing than mcbridei, and there are differences in hingeplate details (Hall and Clarke, 1894, pl. 49, figs. 13, 14).

Trematospira mcbridei resembles T. cooperi Merriam (1940, p. 82, pl. 6, fig. 12) externally and may be a subspecies. Because the interior of cooperi is unknown, however, the relation of these two Early Devonian forms must await preparation of suitable material.

Occurrence.-Lower Devonian Rabbit Hill Limestone. Rabbit Hill, Copenhagen Canyon, locality M409.

\section{Family DELTHYRIDIDAE Waagen, 1883}

Genus Kozlowskiellina Boucot, 1958

1957 Kozlowskiella Boucot, p. 318.

1958 Kozlowskiellina Boucot, p. 1030.

1842 Delthris raricosta Conrad, pl. 14, fig. 18.

1857 Spirifer perlamellosus Hall, p. 57.

1858 Kozlowskiella Boucot, Amsden and Boucot, p. 121.

1963 Kozlowskiellina Boucot, Amsden and Ventress, p. 114.

Type species.-By original designation, Kozlowskiella strawi Boucot, 1957. Wenlock Limestone, Great Britain; west of Wren's Nest, Dudley, England, middle nodular beds of the Wenlock Limestone.

Diagnosis.-Coarse-ribbed spiriferoid brachiopods having frilled growth lamellae, uncomplicated fold and sinus, a strong median septum in the pedicle valve, and a large distinctive double cardinal process. Interarea of pedicle valve long and extensive, that of the dorsal valve insignificant.

Remarks.-As noted by Boucot (1957, p. 318-319), the pedicle valve of Kozlowskiellina is more convex than the brachial. The heavy ribs and interspaces are ornamented by fine radial riblets that project over the concentric lamellae as fringes of small spines. In mature individuals, the deltidial plates are conjunct except for an apical foramen. Dental plates are usually short but stout; in older individuals, these become partly embedded in secondary shell material deposited in the umbonal and delthyrial cavities. The strong median septum extends from one-half to two-thirds the distance to the anterior margin of the pedicle valve. The double cardinal process may be deeply striated.

Hedeina Boucot, 1957 is externally similar to Kozlowskiellina, but lacks the pedicle valve median septum; the cardinal process is not of the distinctive double type found in Kozlowskiellina. Delthyris Dalman, 1828 possesses a thinner median septum in the pedicle valve and differs from Kozlowskiellina by lacking the frilly external lamellae, as well as the distinctive double cardinal process and by having relatively longer and thinner dental lamellae.

Kozlowskiellina occurs in rocks of Middle Silurian age in England (Wenlock Limestone), in the higher parts of the Roberts Mountains Formation of the type section, which is either Middle or Upper Silurian, and is especially characteristic of the Helderberg (Early Devonian) beds of the Rabbit Hill Limestone.

\section{Kozlowskiellina nolani n. sp. \\ Plate 6, figures 16-24}

1963 Kozlowskiellina sp. a, Merriam, p. 43.

Type material.-Holotype, USNM 159589; paratypes, USNM 159586-159588, 159590, 159591, Rabbit Hill Limestone, locality M409. Paratype, USNM 159592, Rabbit Hill Limestone, locality M1309.

Diagnosis.-Kozlowskiellina with narrow hinge line, subquadrangular outline in plane of commissure, and few heavy radial ribs. Ventral valve greatly thickened by adventitious material in umbonal region. Dorsal hinge plate large, with strong bifid cardinal process flanked by thick brachiophore supports.

External features.-Size medium to large for this genus. Hinge line width usually exceeds anteroposterior length. Width of fold at commissure may be more than one-third hinge line width. Fold and sinus broad, deep and rather evenly rounded. Lateral profile strongly biconvex; pedicle valve usually deeper than brachial. Radial costellae limited to one on either side of fold and one lateral to heavy ribs which border the sulcus. Concentric frills usually well developed; threadlike minor ribbing and spines at frill edges are not preserved. Pedicle valve interarea long and apsacline; del- 
thyrial notch makes angle of about $28^{\circ}$. Brachial valve interarea insignificant. Conjunct deltidial plates and foramen not preserved.

Pedicle valve interior.-Muscle fields not distinguishable in mature shells. Median septum high, usually extending more than half the distance from beak to commissure. In early mature stages, septum thin, following floor of delthyrial cavity as a low plate separated from the dental lamellae; with older individuals having umbonal adventitious deposits, the median septum is much thickened posteriorly and merges with thick, short dental plates to form a troughlike pseudospondylium. The median septum commonly swells to an elongate boss on floor of delthyrial cavity. One or more pairs of apically trending grooves occur below teeth along the walls of the delthyrium, converging toward the beak.

Brachial valve interior.-Hinge plate large, slightly less than one-third valve width at hinge line; a bifid cardinal process, lateral to which are expanded brachiophore supports that make up most of the plate. Muscle impressions poorly defined, small, with low dividing ridge just anterior to hinge plate. Spiralia unknown.

Comparison with related forms.-Kozlowskiellina nolani differs from $K$. strawi, the type species, in the narrowness of the shell and convexity of the brachial valve; the brachial valve of $K$. strawi is nearly flat. Compared with $K$. nolani, most described species have a more alate shell and are not known to have the excessive thickening of the pedicle valve median septum on the floor of the delthyrial cavity of older individuals. Perhaps the most closely related is $K$. velata Amsden (Amsden 1958a, p. 121, pl. VIII, figs. 1-13), though it is more alate and has more major costellae and a more angulate fold and sinus. An undescribed species of Kozlowskiellina in the upper Roberts Mountains Silurian is alate and has numerous major costellae and a smaller hinge plate.

Occurrence.-Lower Devonian Rabbit Hill Limestone. Rabbit Hill, Copenhagen Canyon, locality M409. Dobbin Summit, Monitor Range, locality M1309. Petes Canyon area, Northern Toquima Range, locality M1150.

Genus Howellella Kozlowski, 1946

Howellella cycloptera (Hall) subsp. monitorensis n. subsp.

Plate 7, figures 17-22; plate 8, figure 10

1963 Spirifer sp. a, cf. "S." cylopterus Hall, Merriam, p. 43.

Type material.-Holotype, USNM 159604; paratype, USNM 159603; Rabbit Hill Limestone, locality M409. Paratype, USNM 159605; Rabbit Hill Limestone, locality M1311.

Diagnosis.-Howellella with evenly curved fold and sulcus, lateral to which are 5 to 7 prominent evenly rounded radial ribs on each flank. Dental plates short. Ventral muscle field flabellate, usually impressed, markedly striated, with low median partition. Interior of pedicle valve pitted lateral to muscle field. Valve surfaces ornamented by fine radial riblets that are prominent and possibly spinose at concentric incremental edges.

External features.-Lateral profile moderately biconvex, the two valves subequal. Hinge line width usually exceeds length. Shape in commissure plane subovoidal; cardinal extremities rounded. Fold and sulcus uncomplicated. Pedicle valve interarea short, concave-orthocline with hooked beak. Delthyrial notch making angle about $55^{\circ}$. Deltidial plates unknown. Dorsal interarea very short.

Pedicle valve interior.-The fan-shaped impressed, longitudinally striate muscle field undifferentiated except for median ridge, which varies from broad to weak or undefined. Dental lamellae short and ventrally divergent. Pitting of inner valve surface strongest near muscle field, but may extend to valve edge.

Brachial valve interior.-Hinge plate wide, divided and open, with small cardinal process and thin, widely divergent, bladelike brachiophore supports. Muscle attachments weak or unrecognized.

Comparison with related forms. - The Nevada specimens herein classified as a subspecies of cycloptera (Hall) resemble Hall's figures of the New York Helderbergian types rather closely and are quite similar to the Oklahoma Bois d'Arc individuals figured by Amsden (Amsden 1958a, pl. VIII, figs. 14-26). The New York specimens reveal the striated pedicle muscle field and the pitting as in subsp. monitorensis and the exterior pattern of fine surface ornamentation present upon the Bois d'Arc individuals. The Bois d'Arc form reveals a suggestion of a weak median sulcus on the dorsal fold not recognized in subsp. monitorensis. The new subspecies differs markedly from the Silurian Lone Mountain Dolomite species Howellella smithi Waite, which has a flattened fold and sinus near the commissure, fewer lateral plications, and longer, more slender dental plates. Howellella pauciplicata Waite, also of the Lone Mountain, is smaller and has very weak lateral plications.

Occurrence.-Lower Devonian Rabbit Hill Limestone. Rabbit Hill, Copenhagen Canyon, locality M409. Dobbin Summit, Monitor Range, locality M1311. Coal Canyon, Simpson Park Range, locality M1075.

Genus Acrospirifer Helmbrecht and Wedekind, 1923

1923 Acrospirifer Helmbrecht and Wedekind, p. 952.

1944 Acrospirifer Wedekind. Cooper, p. 323.

1963 Hysterolites (Acrospirifer) Helmbrecht and Wedekind, 1923. Amsden and Ventress, p. 105. 
Type species.-Spirifer primaevus Steininger (Cooper, 1944, p. 323; Amsden and Ventress, 1963, p. 108). Lower Devonian, Germany.

Diagnosis.-Cooper (1944) characterizes Acrospirifer as follows: “***Subsemicircular to transversely semielliptical, costate and lamellose spiriferoids; fold and sulcus noncostate; dental plates strong, muscular field large, elongate-oval; dorsal interior with thick socket plates."

Remarks.-Amsden and Ventress (1963,p. 105-111) have reviewed the present status of Acrospirifer in connection with the relations of $A$. murchisoni (Castelnau). These writers treat Acrospirifer as a subgenus of Hysterolites Schlotheim 1820, following the usages of Maillieux (1941) and Havlicek (1959).

Acrospirifer kleinhampli n. sp.

Plate 7, figures 9-12

Type material.-Holotype, USNM 159599; paratype, USNM 159600. Rabbit Hill Limestone, locality M1309.

Diagnosis.-Large Acrospirifer with rather narrow hinge line for the genus, short dental lamellae, and 6 or 7 radial ribs on either side of the ventral sulcus. Mature individuals may show a tendency toward splitting of radial ribs anteriorly.

Externalfeatures.-Cardinal extremities subrounded to subangulate. Radial ribs rounded, rather closely spaced and numerous for the genus. Pedicle sulcus deep and usually subangular toward the commissure of mature shells; brachial fold prominent and subrounded. Concentric lamellae not prominent, obscured because of silicification. Splitting or doubling of radial ribs toward the anterior margin of large individuals appears to be characteristic. Beak of pedicle valve slightly hooked. Pedicle interarea well defined but less extensive laterally than in other species of this genus. No trace of deltidial plates was noted.

Pedicle valve interior.-Dental lamellae short and obtuse for this genus. Muscle field large, rather deeply impressed and striated.

Brachial valve interior.-Hinge plate with thin dorsally projecting flange medial to brachiophore as in Acrospirifer kobehana (Merriam); flange does not meet internal valve surface.

Comparison with related forms.-Acrospirifer kleinhampli differs from A. kobehana (Merriam) by being somewhat smaller, with narrower hinge line and laterally less extensive ventral interarea. The dental lamellae of kobehana are longer and thinner. The radial ribs of kobehana are heavier, fewer, and more widely spaced. Acrospirifer kleinhampli resembles A. murchisoni (Castelnau) but appears to be narrower (see Amsden and Ventress, 1963, pl. VI) and less alate. The complex pattern of concentric lamellae shown by murchisoni is not known in kleinhampli, possibly because of preservation by silicification.

Occurrence.-Rabbit Hill Limestone. Dobbin Summit, Monitor Fange, locality M1309 in the higher beds of this formation.

Family COSTISPIRIFERIDAE Termier and Termier, 1949 Genus Costispirifer Cooper, 1942

1942 Costispirifer Cooper, p. 230.

1944 Costispirifer Cooper, p. 323, pl. 122, figs. 27-31.

1963 Costispirifer Cooper, Amsden and Ventress, p. 111-114, pl. 5, figs. 3-11, text-fig. 35 .

Type species.-Spirifer arenosus planicostatus Swartz (1930, p. 56-57, pl. 9, figs. 13-15) by author designation. From cherts in the upper part of the Giles Formation near Saltville, Va. Lower Devonian. Cooper (1942) regarded Costispirifer planicostatus (Swartz) as a distinct species.

Diagnosis.-Large spirifers with costate fold and sulcus. The costae are broad and flat with narrow interspaces; costae ornamented with fine radial lines. Dental plates strongly developed. In brachial valve, the crural bases cup shaped and welded to sides of valve; notothyrial cavity broad and moderately deep. Delthyrium covered by a short convex pseudodeltidium.

Remarks.-Spirifers similar to the eastern Oriskany Costispirifer arenosus (Conrad) are the most diagnostic and abundant brachiopods of Early Devonian (Siegenian) beds of the Great Basin, where they occur with large horn corals belonging to the Subfamily Papiliophyllinae. First recognized in the Roberts Mountains (Merriam, 1940, p. 50, pl. 7, fig. 17, pl. 11, fig. 17), these spirifers have been collected in large numbers from arenaceous limestones of Nevada formation unit 1 in the Sulphur Spring Range. Most specimens are pedicle valves that exhibit flattening of ribs toward the anterior margin of large shells; otherwise the costae are rounded. Fine, delicate costellae were not observed on ribs of unpeeled valves. A high percentage of these shells appear to be especially wide at the hinge line as compared with more elongate figured specimens from the eastern Oriskany (Schuchert and Maynard, 1913, pl. 71, figs. 3, 8, 9).

In silicified pedicle valves from the upper part of the Hidden Valley Dolomite, Panamint Mountains, Calif., the teeth are small and the short dental plates especially heavy where they form a buttress beneath the interarea.

No far-western Costispirifers showing the very wide, flattened costae of Costispirifer arenosus var. planicostatus Swartz (1930, pl. 9, figs. 13, 14) have been recognized. Cooper (1942, p. 232) elevated Swartz's variety to a species separate from $C$. arenosus (Conrad) upon designating planicostatus as type species of 
Costispirifer.

Amsden and Ventress (1963, p. 111-114) have reviewed the relations and distribution of American Costispirifer, noting the taxonomic importance of flat costae and narrower interspaces.

On the whole, differences in shell and ornamentation are not great when the New York, Oklahoma, and Great Basin forms are compared. The various geographic taxa might reasonably be regarded as subspecies; some selected Nevada specimens are quite similar morphologically to some of those from the Appalachian belt as well as Oklahoma.

Appearance of Costispirifer of the arenosus type in the higher Rabbit Hill fauna at Dobbin Summit, Monitor Range, suggests that these beds are probably little older than Nevada unit 1, in which very similar brachiopods become dominant.

Costispirifer arenosus (Conrad) subsp. dobbinensis n. subsp. Plate 7, figures 1-7

Type material.-Holotype, USNM 159594; paratypes, USNM 159593, 159595-159597. Rabbit Hill Limestone, locality M1309.

Diagnosis.-Large Costispirifer arenosus with shallow to moderately deep pedicle valve sulcus, large deeply impressed ventral muscle field, short dental lamellae, and heavy dental lamella buttresses beneath the palintrope. The convex pseudodeltidium beneath the incurved beak is short and rather heavy.

Remarks.-The Dobbin Summit pedicle interiors reveal deeply impressed muscle scars and very short dental plates, except for the greatly thickened buttress beneath the interarea. The convex pseudodeltidium beneath the beak is short and rather heavy.

This subspecies, judged by pedicle valve exterior features, is specifically like $C$. arenosus from Nevada unit 1. Wide individuals of subspecies dobbinensis resemble wide shells of the Hidden Valley Dolomite form, which have a somewhat more slender dental lamella buttress.

The dorsal features of subspecies dobbinensis, like the Nevada unit 1 form, are poorly known, because most of the preserved shells are pedicle valves. Validity of dobbinensis as a subspecies must therefore await comparison of brachial valve features, likewise poorly known in the Hidden Valley representatives. The likelihood that dobbinensis is ancestral suggests that differences in the ventral interior may be borne out in the rest of the shell when that is better understood.

Occurrence.-Lower Devonian Rabbit Hill Limestone. Upper beds of the Rabbit Hill Limestone, Dobbin Summit, Monitor Range, locality M1309. Fragmentary shells possibly belonging to this subspecies have been collected from higher beds of the Rabbit
Hill Limestone at Coal Canyon, Simpson Park Range, locality M1076.

\section{TENTACULITIDS AND CONULARIIDS OF THE RABBIT HILL LIMESTONE}

Shells of Conularia are locally associated with abundant tentaculitids in platy limestones and calcareous shale interbeds of the Rabbit Hill Limestone. Southeast of Walti Ranch (locality M1074) in the Simpson Park Range, such platy beds with Conularia contain small slender tentaculitids (pl. 8, fig. 18) having the ornamentation of Nowakia acuaria Richter. Trilobites Leptocoelia, Pleurodictyum, and Syringaxon also occur in this assemblage. Similar tentaculitids are present in platy Rabbit Hill interbeds at Coal Canyon, northern Simpson Park Range. In the Devonian of the Great Basin, Nowakia-like shells are most abundant in the Middle Devonian strata of Nevada Formation unit 4, where smooth Styliolina also is common. No large coarsely ribbed benthonic tentaculites like those of shaly interbeds of Nevada Formation unit 2 were observed in the Rabbit Hill.

\section{Subclass CONULATA Moore and Harrington Order CONULARIDA Miller and Gurley Family CONULARIDAE Walcott Conularia sp. cf. C. huntiana Hall Plate 2, figures $18-20$}

Figured material.-USNM 159536, 159537; Rabbit Hill Limestone, locality M1074, Walti Ranch, Simpson Park Range.

Flattened shells of this delicate Conularia range in length from $30 \mathrm{~mm}$ to more than $400 \mathrm{~mm}$. The sharply sculptured transverse ribs are uniform, about 40 per $\mathrm{mm}$, and ornamented by close-spaced small tubercles. In some individuals these tubercles are round, in others elongate and drawn out longitudinally toward the interspaces, but not to the extent shown in Hall's figure (1859-61, pl. 72A, figure 2b) of the Helderbergian $C$. huntiana.

Similar Conularia occurs in the Early Devonian Hunsrückschiefer of Bundenbach, Germany.

Occurrence.-Rabbit Hill Limestone, locality M1074 southeast of Walti Ranch, Simpson Park Range.

\section{MOLLUSCA OF THE RABBIT HILL LIMESTONE}

Mollusca, greatly outnumbered by the brachiopods, are generally not conspicuous in the Rabbit Hill Limestone. Residues from hydrochloric acid solution of Rabbit Hill bioclastic limestones yielded few lamellibranchs; their shells evidently were less amenable to silicification than were those of brachiopods, corals, and gastropods. Most gastropods so obtained are allied to Platyceras. Fragmentary straight Orthoceras-like shells of small size were the only cephalopods recog- 
nized. No identification of the fragmentary lamellibranchs was attempted.

\section{Family PLATYCERATIDAE Hall Genus PIatyceras Conrad}

Three kinds of Platyceras occur in the type Rabbit Hill bioclastic limestones; these range in configuration from nearly planospiral through openly planospiral to somewhat helicospiral and disjunct. None of the large, excessively spinose forms of Platyceras like those that characterize lower beds of the Nevada Formation (unit 1) were found in the Rabbit Hill.

\section{Platyceras sp. a}

Plate 1, figures 20, 21

Platyceras sp. a (USNM 159524) is nearly planospiral, smooth, comprises two whorls and has an ovoidal aperture and open umbilicus.

Occurrence.-Rabbit Hill Limestone. Rabbit Hill, Copenhagen Canyon, locality M409.

Platyceras sp. b

Plate 1, figures 22, 23

Platyceras sp. b (USNM 159525) is more typical of the genus, a small form with a single open whorl. The aperture is nearly round with generating curve increasing rapidly in diameter. Sinuosity of the growth line conforms to an irregular aperture margin with five minor embayments.

Occurrence.-Rabbit Hill Limestone. Rabbit Hill, Copenhagen Canyon, locality M409.

\section{Platyceras (Orthonychia) sp. c Plate 1, figure 24}

Platyceras (Orthonychia) sp. c (USNM 159526) is a small disjunct species comprising two whorls with the character of the subgenus Orthonychia and having a very elongate, straight body whorl. Growth lines and aperture margin show two broad embayments.

Occurrence.-Rabbit Hill Limestone. Rabbit Hill, Copenhagen Canyon, locality M409.

\section{TRILOBITES OF THE RABBIT HILL LIMESTONE}

Trilobites of the families Odontopleuridae and Phacopidae are the common fossils at some exposures of the Rabbit Hill Limestone. This is especially true of the platy limestones in the Simpson Park Range west of McClusky Peak and at Coal Canyon. In the type area at Rabbit Hill, Monitor Range, and at Dobbin Summit, trilobite remains are abundant in some beds, whereas in the richly fossiliferous bioclastic lenses where the brachiopods and corals are silicified, the trilobites are not replaced by silica and do not appear in the acid residues. Thin beds in which trilobite remains are the common fossils yielded a few weathered specimens. Some of these beds are a virtual "trilobite hash" from which, by repeated splitting of large amounts of rock, well-preserved but disarticulated fragmentary trilo- bites may be prepared (pl. 8, figs. 12,13). Most of these are small spiny Odontopleuridae; it is unlikely that articulated or complete specimens can be obtained from these bioclastic beds.

Material available is not sufficient to justify more than a cursory review of the Rabbit Hill trilobites, referring the few kinds collected to the nearest described species. Trilobite beds yielding better material will doubtless be found by careful search of the Simpson Park exposures, in particular those at Coal Canyon and near McClusky Peak (Walti Ranch), where fragmentary larger phacopids are abundant. It is probable that most of the Rabbit Hill trilobites are undescribed species, in view of the lack of study of far-western Devonian trilobites.

\section{Family ODONTOPLEURIDAE Burmeister 1843}

Spiny trilobites of this family predominate in some trilobite beds of the Rabbit Hill Limestone. Leonaspis is the abundant genus, long-forked structures indicate the presence of other genera such as Miraspis and Odontopleura. Trilobites of this family seem to be uncommon in the Devonian section of this province above the Rabbit Hill; none were found in the Lower Devonian beds of Oriskany age in Nevada Formation unit 1. Leonaspis occurs sporadically somewhat higher in Nevada unit 2 of the southern Sulphur Spring Range northwest of Romano Ranch, where it was found associated with Spirifer pinyonensis in very sandy limestones.

\section{Genus Leonaspis Richter and Richter, 1917 Leonaspis cf. L. tuberculatus (Hall), 1859 Plate 2, figures 15-17}

1859 Acidaspis tuberculatus Hall, p. 368-370; pl. 79, figs. 1-14. 1956 Leonaspis tuberculatus (Hall, 1859). Whittington, p. 507509 , pl. 57, figs. 1-9.

1963 Leonaspis sp. cf. L. tuberculatus (Hall). Merriam, p. 43.

Collections from the Rabbit Hill Limestone in its type section include a number of isolated free cheeks, pygidia, and hypostomas of this form well enough preserved for identification. No cranidea were found. Free cheeks have been identified at most Rabbit Hill collecting localities.

The mature free cheek is similar to those illustrated by Hall (1859), having 12 or 13 lateral spines, a marginal row of rather coarse tubercles and scattered tubercles on the convex part of the cheek, these being more numerous internally. The lateral spines are less acute than on Hall's illustrations and more like those shown by Whittington (1956, pl. 57, fig. 7; pl. 58, figs. $3,4)$ for Leonaspis tuberculatus and L. williamsi.

The pygidium has a general pattern quite similar to L. tuberculatus as illustrated by Whittington (1956, pl. 57, fig. 4), but the paired tubercles are smaller on the Rabbit Hill specimens and the median tubercle at 
the axial tip of L. tuberculatus is weak or absent. The differences in the two pygidia suggest only subspecific differences.

\section{Genus Miraspis Richter and Richter, 1917 (?)Miraspis sp. \\ Plate 2, figure 14}

Elongate paired or forked occipital ring spines are associated with Leonaspis in trilobite beds of the Rabbit Hill Limestone. These spines probably came from an odontopleurid genus such as Miraspis or possibly Odontopleura, two genera believed to be limited to the Silurian.

Family PHACOPIDAE Hawle and Corda, 1847

Trilobites of this family are common in certain beds of the Rabbit Hill Limestone in its type section. In some platy limestones of the Simpson Park Range, phacopids are the most numerous fossils. Only one genus, Phacops, has been recognized. There is some specific diversity, as between those with a genal spine and those lacking this feature. Although some of the material is fairly well preserved, most of the specimens are fragmentary. In this region phacopids are numerous in the Lower and lower Middle Devonian through Nevada Formation unit 2, but material available is insufficient for detailed species comparison.

\section{Genus Phacops Emmrich, 1839 \\ Phacops sp. A, cf. P. logani Hall, 1861 \\ Plate 8, figures 16, 17}

This form is represented at Rabbit Hill by fragmentary small to medium-sized pygidia that are not conspicuously postulose and do not show a rim. The cephalon is unknown. The pygidia also resemble those of var. gaspensis and var. birdsongensis as figured by Delo (1940, pl. 1, figs. 10-12, 13-15).

(?)Phacops sp. B, cf. P. canadensis Stumm Plate 2, figures 11-13

Large phacopids with well-defined pygidial rim occur at Coal Canyon, Simpson Park Range. They are represented in the collections by a nearly complete articulated specimen and by a partial crushed cephalon.

The inflated glabella and short pygidium indicate that this form is probably related to the genus Phacops. There are, however, decided differences, among them a narrowness behind the swollen frontal glabellar lobe and the presence of genal spines.

Among the described Phacopidae, Phacops canadensis Stumm( 1954, p. 213, pl. IV, figs. 7, 15, 18) possesses a short genal spine but differs in features behind the swollen frontal lobe. The thorax and pygidium of $P$. canadensis are unknown.

Pygidia associated with the cephalon of this species are of medium to rather larger size and have a narrow rim not recognized in Phacops sp. A.

\section{Family DAIMANITIDAE Vogdes, 1890}

The remains of larger trilobites from the Rabbit Hill Limestone include a large incomplete dalmanitid cephalon from the Coal Canyon section, Simpson Park Range. This individual was about $60 \mathrm{~mm}$ wide in the anterior part of the thorax. Although possibly a species of Dalmanites, preservation is too imperfect for a definite generic assignment.

\section{Order RUGOSA Edwards and Haime, 1850 Family TRYPLASMATIDAE Etheridge, 1907 Genus Tryplasma Lonsdale, 1845}

1845 Tryplasma Lonsdale, p. 613.

1871 Pholidophylum Lindström, p. 925.

1894 Spiniferina Penecke, p. 592.

1907 Tryplasma Lonsdale. Etheridge, p. 76-77.

1927 Tryplasma Lonsdale. Lang and Smith, p. 461.

1927 Pholidophyllum Lindström. Wedekind, p. 25.

1927 Stortophyllum Wedekind, p. 30.

1936 Tryplasma Lonsdale. Hill, p. 204.

1940 Tryplasma Lonsdale. Lang, Smith, and Thomas, p. 135.

1940 Pholadophyllum Lang, Smith, and Thomas, p. 99.

1940 Tryplasma Lonsdale. Hill, p. 405.

1950 Tryplasma Lonsdale. Schouppé, p. 80-84.

1952 Tryplasma Lonsdale. Stumm, p. 841-843.

1956 Tryplasma Lonsdale. Hill, p. F312.

1960 Tryplasma Lonsdale. Oliver, p. 96.

1962 Tryplasma Lonsdale. Oliver, p. 13.

Type species.-Tryplasma aequabile Lonsdale, 1845 ; by subsequent designation (Etheridge, 1907, p. 42). Silurian near Bogoslovsk; east of northern Ural Mountains, Russia.

Diagnosis.-Solitary and fasciculate rugose corals with acanthine septa that are vertical columns of trabecular spines. Corallites elongate or subcylindrical. Septal stereozone medium wide to narrow. No dissepiments. Tabulae mostly complete, commonly straight and widely spaced.

Remarks.-Tryplasma and related corals with acanthine septa have been the subject of special studies by Hill (1936), Schouppé (1950), Stumm (1952), and Oliver (1960). Species of this genus are characteristic of Silurian deposits in Europe, Australia, and North America; as noted by Duncan (1956, p. 226-227; figs. $3 a-b)$, they are among the common fossils in the Silurian of western North America. Oliver (1960, p. 96) notes that Tryplasma extends its range into the Lower Devonian of Europe, Australia, and eastern North America.

The genus Tryplasma as understood includes species that differ considerably in growth habit, ranging from solitary ones with elongate corallum showing repeated rejuvenescence rims to bushy phaceloid colonies whose slender branches are cylindrical and relatively smooth.

These corals are well represented in the Silurian limestone facies of the west-central and southwest 
parts of the Great Basin but are poorly known in the dolomite facies.

\section{Tryplasma sp. $f$}

Plate 11, figures 24, 25

Isolated nondissepimented, cyclindrical corallites in the upper part of the Lone Mountain Dolomite of the Fish Creek Range are assigned to Tryplasma. The complete tabulae range from straight to undulant and sagging. Moderately long acanthine septal spines are well shown in both transverse and longitudinal thin sections.

Occurrence.-Upper Silurian, upper part of the Lone Mountain Dolomite. Southern Fish Creek Range, locality M1087 in association with Entelophyllum engelmanni and the Howellella brachiopod fauna.

\section{Family KYPHOPHYLLIDAE Wedekind, 1927}

Reference form.-Kyphophyllum lindströmi Wedekind. Silurian, Gotland, Sweden.

The Kyphophyllidae are mostly colonial phaceloid, less commonly cerioid genera among which the fasciculate species with long subcylindrical corallites predominate. Long lamellar septa are characteristic, with one to several dissepiment columns, the outer of which are lonsdaleioid in some species. Tabulae are fairly wide, arched in some genera; in a few species a flaring calice rim is present.

Described genera provisionally included in this family are:

Kyphophyllum Wedekind, 1927

Strombodes Schweigger, 1819

Petrozium Smith, 1930

Entelophyllum Wedekind, 1927

Entelophylloides Rukhin, 1938

Neomphyma Soshkina, 1937

At least two generic or subgeneric groups within the Kyphophyllidae of the Great Basin Silurian remain undescribed. All members of this family appear to be restricted to the Silurian System.

\section{Genus Entelophyllum Wedekind, 1927}

Entelophyllum Wedekind, p. 22-24, pls. 2, figs. 11-12, pl. 7, figs. 7-10, pl. 29, figs. 18-51.

1927 Xylodes Lang and Smith, p. 461-462, figs. 13-14.

$1929 X y$ lodes Lang and Smith. Smith and Tremberth, p. 362367 , pl. 7, figs. 1-6, pl. 8, figs. $2-4$.

1933 Xylodes rugosus Smith, p. 516, figs. 6-7.

1940 Entelophyllum Wedekind. Lang, Smith, and Thomas, p. 57-58.

1940 Entelophyllum Wedekind. Hill, p. 411.

1940 Xylodes articulatus (Wahlenberg). Prantl, p. 10-13, pl. 1 , figs. 1-3, pl. 2, figs. 1, 3, 4 .

1956 Entelophyllum. Duncan, pl. 23, figs. 5c-d.

1956 Entelophyllum Wedekind. Hill, p. F275, fig. 187, 2a-c.

1962 Entelophyllum Wedekind. Oliver, p. 15, pl. 6, figs. 11-12.
1962 Entelophyllum Wedekind. Stumm, p. 2-3, pl. 1, figs. 6-8, pl. 2, figs. 9-11.

1964 Entelophyllum Wedekind. Stumm, p. 32, pl. 22, figs. 9-21.

Type species.-Madreporites articulatus Wahlenberg=Entelophyllum articulatum (Wahlenberg); by subsequent designation, Lang, Smith, and Thomas $(1940$, p. 57, 140). Silurian, Gotland, Sweden. According to Smith and Tremberth $(1929$, p. 366), this species occurs in strata of Wenlock and Ludlow ages on the Island of Gotland and is recorded from the Wenlock Limestone in England.

Diagnosis.-Phaceloid, possibly in part solitary rugose corals with elongate subcylindrical corallites. Major septa thin, slightly thickened near outer wall only; longer septa approach the axis. Tabularium wide, typically with close-spaced flat tabulae or tabellae and narrow peripheral sag bordering dissepimentarium. Dissepimentarium having few to many columns of small steeply inclined globose dissepiments. Outer wall thin, lacking a stereozone. No fossulae or other indication of bilateral symmetry in mature stages. Septa slightly to moderately wavy; well-developed elbow carinae not present in typical form. Attachment wall outgrowths characterize some species. Five or six reproductive offsets, marginal to calice.

Remarks. - Not all Entelophyllum species have the well-defined peripheral depressed zone of the tabularium shown by the type species. Entelophyllum pseudodianthus (Weissermel) of the English Wenlock has zigzag thickened and carinate septa and less elongate cylindrical corallites (Smith and Tremberth, 1929, p. 361-362; Lang and Smith, 1927, p. 475, fig. 15); possibly subgenerically or even generically distinct from Entelophyllum sensu stricto.

Disphyllum of the Middle Devonian resembles Entelophyllum externally, but differs by having generally slender corallites that lack the thick attachment outgrowths of Entelophyllum. Disphyllum also lacks the peripheral depressed tabular zone of typical Entelophyllum, has more even septa without carinae, and commonly has a somewhat wider tabularium. Transverse sections of Disphyllum show a more uniform and even concentric distribution of axially concave dissepiment traces. Some species of Entelophyllum have a cycle of reproductive offsets at the calice margin, a characteristic not found in Disphyllum.

Entelophyllum engelmanni n. sp. Plate 10, figures 5-11

Type material.-Holotype, USNM 159413; paratypes, USNM 159414-159418.

Diagnosis.-Phaceloid Entelophyllum forming large laterally extensive bushy colonies of nearly straight cylindrical corallites joined by lateral outgrowths. 
Tabularium wide, tabulae mostly complete, subparallel, usually lacking the peripheral sag of typical Entelophyllum. Tabulae with axial-periaxial sag or slightly arched distally. Tabellae uncommon. Major septa withdrawn from axis, slightly wavy and without carinae; minor septa short, usually less than one-half the length of major septa. Septa thin toward axis, but with wedge thickening peripherally. No stereozone.

Externalfeatures.-Very elongate cylindrical mature corallites, large for this genus, with well-defined septal grooves crossed by annular incremental striations. Coarse annular folds or rugae few. Some corallites have thick irregular lateral attachment outgrowths distributed vertically along one side.

Transverse sections. - Major septa about 28, thinned axially and slightly withdrawn from the axis. Minor septa less than one-half the length of major septa. All septa thicken rather abruptly in wedge fashion toward outer wall, which is very thin. Septa slightly wavy, lack carinae. Dissepiments not numerous, somewhat irregular as chevrons, forks, and simple traces that are either almost straight or slightly concave axially.

Longitudinal sections.-Tabularium wide, about two-thirds of corallite diameter. Tabulae mostly complete, varying from straight or slightly arched axially and periaxially with or without peripheral depression to those with axial-periaxial sag and no peripheral depression. A few broad, flat tabellae peripherally. Dissepiments globose in one to three columns, steeply inclined, and of small, medium, and large size.

Comparison with related forms.-Entelophyllum engelmanni differs from $E$. eurekaensis in the unevenness of its tabulae, which usually lack the peripheral depression. The extensively developed lateral connecting excrescences of this species were not observed in E. eurekaensis.

Occurrence.-Late Silurian, upper part of the Lone Mountain Dolomite; upper Lone Mountain-Laketown biofacies. Southern Mahogany Hills, locality M1112. Northern Fish Creek Range, locality M1087. A similar Entelophyllum occurs in Silurian dolomite of the Ruby Mountains.

Entelophyllum engelmanni subsp. b

Plate 10, figures 12, 13; plate 11, figures 26, 27

Entelophyllum engelmanni with subcylindrical corallites attaining large size and having diameters exceeding $1 \frac{1}{4}$ inches or about twice normal for the species. The large corallites have some 38 major septa, steeply inclined dissepiments, no septal stereozone, and in some instances unusually thick and prominent external attachment processes. External rugae and protuberances more prominent than in typical form.
Occurrence.-Late Silurian, upper part of the Lone Mountain Dolomite. Southern Fish Creek Range, locality M1087.

$$
\begin{aligned}
& \text { Entelophyllum eurekcensis n. sp. } \\
& \text { Plate 10, figures 1-4 }
\end{aligned}
$$

Type material.-Holotype, USNM 159412; paratype, USNM 159419.

Diagnosis.-Subcylindrical to ceratoid Entelophyllum with wide tabularium and closely spaced, straight, nearly continuous tabulae and flat peripheral tabellae. Peripheral zone of tabularium proximally depressed as in typical Entelophyllum. Septa slightly thickened, longer major septa approach axis. In transverse sections, the small to medium sized dissepiments show as axially concave and chevron traces.

External features.-This species, known only from isolated pieces, is assumed to have been bushy and phaceloid like $E$. engelmanni of the same beds. However, available specimens of eurekaensis are more nearly ceratoid than cylindrical in shape.

Transverse sections.-Major septa about 30; most are withdrawn, but a few approach the axis. Minor septa range from short wedge stumps to about one-half the length of major septa. Septa somewhat thicker than in most Entelophyllum species and show only a little waviness. No carinae recognized. Dissepiments include herringbone and chevron traces as well as concentric and axially concave. Septa thicken markedly in wedge fashion toward outer wall, but there is no continuous septal stereozone. Epitheca rather thin.

Longitudinal sections. - Tabularium width about two-thirds corallite diameter. Most tabulae nearly complete, axially-periaxially very flat, peripherally depressed as in typical Entelophyllum. Flat peripheral tabellae present. Dissepiments in as many as five columns, of which the outer may have nearly horizontal basal planes; larger dissepiments elongate.

Comparison with related forms.-This species has much flatter, more even tabulae than engelmanni; tabulae are more closely spaced and have a well-defined peripheral sag. Dissepiments of eurekaensis are on the whole less steeply inclined, occur in more numerous columns, and are less globose. The bushy and cylindrical growth habit of engelmanni is not known in this species. No individuals of eurekaensis with prominent external attachment processes are known.

Occurrence.-Late Silurian, upper part of the Lone Mountain Dolomite; upper Lone Mountain-Laketown biofacies. Southern Fish Creek Range, locality M1113; associated with the Howellella-Camarotoechia-Atrypa brachiopod assemblage of this facies. 


\author{
Phylum BRACHIOPODA \\ Class ARTICULATA Huxley, 1869 \\ Order ORTHIDA Schuchert and Cooper, 1932 \\ Family ENTELETIDAE Waagen, 1884 \\ Genus Salopina Boucot, 1960 \\ Salopina sp. $f$ \\ Plate 11, figures 16-23
}

Small Dalmanellacea possessing an elongate ventral palintrope and a variously extended dorsal valve median septum are among common brachiopods in Silurian and Early Devonian rocks of the Great Basin. Need for taxonomic revision within this large and complex orthoid group has recently been indicated by detailed studies of dalmanellid morphology and systematics (Williams and Wright, 1963). Recently proposed generic names possibly applicable to certain of these taxa in the Great Basin Province are Salopina Boucot (1960), Protocortezorthis Johnson and Talent (1967b), and Muriferella Johnson and Talent (1967a).

Salopina sp. $\mathrm{f}$ is known mainly from silicified shells with valves articulated and showing only external features. Among newly described dalmanellid species, the closest similarities appear to be with the Late Silurian Salopina? sp. of Boucot (1960, pl. 1, figs. 1-5), from Devon Island, Northwest Territories, Canada, and Salopina cf. S. crassiformis (Kozlowski) of Johnson and Talent (1967a) from the Roberts Mountains. Better preserved interiors are required to fully establish these relations.

Occurrence.-Late Silurian, upper part of the Lone Mountain Dolomite; Southern Fish Creek Range, locality M1113.

\section{Order RHYNCHONELLIDA Kuhn, 1949 \\ Family CAMAROTOECHIIDAE Schuchert and Levene, 1929 Genus Camarotoechia Hall and Clarke, 1893}

Brachiopods of the Camarotoechia group are among the abundant and diverse fossils of the upper part of the Lone Mountain Dolomite. At least three forms are recognized, Camarotoechia pahranagatensis Waite, a related form designated as $C$. sp. b, and a finely ribbed species resembling $C$. bieniaszi Kozlowski of the Polish Borszczow beds to which the designation $C$. sp. $\mathrm{f}$ is applied here. Camarotoechia-like brachiopods similar to $\mathrm{sp} . \mathrm{b}$ and pahranagatensis have been described by Johnson and Reso (1964) from correlative Late Silurian beds of the Pahranagat Range.

\section{Camarotoechia pahranagatensis Waite Plate 11, figures 7-9}

1956 Camarotoechia pahranagatensis Waite, pl. 3, figures 1-5.

The shell assigned to this species agrees well in general proportions, strength, and number of radial ribs, and emargination of the anterior commissure with Waite's figures of the holotype.

Occurrence.-Late Silurian, upper part of the Lone Mountain Dolomite; Southern Fish Creek Range, locality M1113.

\author{
Camarotoechia sp. b \\ Plate 11, figures 10-13
}

This form is characterized by a pair or, less commonly, three prominent radial ribs in the fold and sulcus; these ribs are more pronounced than in C. pahranagatensis. Ferganella? lincolnensis Johnson (Johnson and Reso, 1964, pl. 19, figs. 5-12) differs by having three or more prominent ribs in fold and sulcus.

Occurrence.-Same as C. pahranagatensis at locality M1113.

$$
\begin{aligned}
& \text { Camarotoechia sp. } f \\
& \text { Plate 11, figures 5, } 6
\end{aligned}
$$

This finely ribbed form with weakly developed fold and sulcus is with some hesitation referred to as Camarotoechia; it is rather certainly unrelated to the other brachiopods of the upper Lone Mountain fauna placed in that genus, sharing some of its external features with Trematospira and Atrypa. Externally similar brachiopods have been described by Kozlowski (1929, p. 158, pl. V, figs. 12-14) as Camarotoechia bieniaszi from the Borszczow beds of Poland.

Occurrence.-Same as C. pahranagatensis and sp. b at locality M1113.

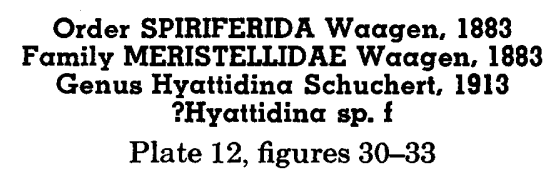

Small, smooth biconvex Hyattidina-like and Nucleospira-like brachiopods, most less than $8 \mathrm{~mm}$ wide, are very abundant in the upper Lone Mountain faunas. Most of these articulated shells are probably immature growth stages of such Spiriferacea as Hyattidina and Hindella. Brachial valves from Mahogany Hills locality M1112 have hinge-plate features suggestive of Hyattidina congesta (Conrad); larger shells from locality M1087 in the Fish Creek Range reveal spiralia with lateral apices and pedicle valve muscle fields similar to ?Hyattidina hesperalis (Waite) of the Laketown Dolomite. Larger and more robust shells in these Lone Mountain faunas are assigned to the genus Hindella and are described separately.

?Hyattidina hesperalis (Waite) was initially placed in Protathyris Kozlowski (Waite, 1956) and later referred to Hyattidina Schuchert by Johnson and Reso (1964). ?Hyattidina sp. f from the Lone Mountain Dolomite has no well-defined fold and sulcus, differing in this respect from mature Hyattidina congesta and the Laketown hesperalis. The largest shells of ?H. sp. f show a slight emargination of the commissure suggesting incipient fold-sulcus development.

Externally very similar shells are described and illustrated by Norford (1962) from the Silurian Sand- 
pile Dolomite of Northern British Columbia. The Sandpile species is assigned by Norford to Glassia variabilis Whiteaves. ?Hyattidina $\mathrm{sp}$. $\mathrm{f}$ has a spiralium like that of the Meristellidae, with lateral apices of cones; Glassia Davidson by definition has the spiralium apices situated at the middle of the brachial cavity (Schuchert, 1913, p. 409).

Occurrence.-Late Silurian, upper part of the Lone Mountain Dolomite; upper Laketown-Lone Mountain biofacies. Southern Mahogany Hills, locality M1112, in association with Howellella pauciplicata and Entelophyllum engelmanni. Southern Fish Creek Range, locality M1087, in association with Howellella smithi and Entelophyllum engelmanni.

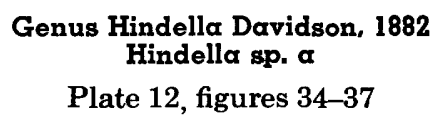

Hindella with valves about equally convex, length but slightly greater than width. Anterior commissure conspicuously bowed; fold of dorsal valve very weak anteriorly, ventral valve with incipient sulcus. Shell smooth except for incremental lines that are numerous near the commissure. This species is relatively wider than both $H$. prinstana and $H$. umbonata, and depth of the dorsal valve is more nearly that of the ventral valve.

The interior of $H$. sp. a is unknown, leaving the generic assignment uncertain. Some of the small and possibly immature shells found in association and here interpreted as belonging to ?Hyattidina sp. $\mathrm{f}$ may be the young of Hindella sp. a.

Atrypella carinata Johnson (Johnson and Reso, 1964) has similar features in the beak vicinity, a more elongate shell with better defined fold and sulcus.

Occurrence.-Late Silurian, upper part of the Lone Mountain Dolomite, locality M1087, Southern Fish Creek Range.

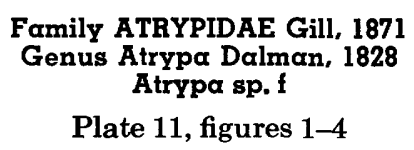

Small to medium-sized Atrypa with coarse radial costae, moderate even upward bowing of the anterior commissure, and rather weakly defined growth lamellae which produce small costal nodes. Costae may bifurcate anteriorly. Convexity of brachial valve does not greatly exceed that of pedicle valve.

Among described American Silurian atrypas, this species appears closest to A. tennesseensis Amsden of the Brownsport and Henryhouse, but differs by having less prominent growth lamellae. Atrypa sp. of Johnson and Reso (1964) from the Silurian of the Great Basin has similar ornamentation and possibly represents the same species as Atrypa sp. f.
Occurrence.-Late Silurian, upper part of the Lone Mountain Dolomite, Southern Fish Creek Range, locality M1113.

\section{Family DELTHYRIDIDAE Waagen, 1883 \\ Genus Howellella Kozlowski, 1946}

Small and medium-sized spiriferoids of this genus are the most distinctive fossils of the Late Silurian dolomites of the Great Basin. These shells have a conspicuous fold and sulcus and strong dental lamellae, and lack a ventral valve median septum. The coarse radial costae which characterize this genus may become nearly obsolete laterally in some species. Howellella ranges from Late Silurian into the Helderbergian Rabbit Hill Limestone, where it is represented by a larger species allied to H. cycloptera.

\section{Howellella pauciplicata Waite \\ Plate 12, figures 20-24}

1956 Howellella pauciplicata Waite, p. 17, pl. 3, figs. 6-10.

1964 Howellella pauciplicata Waite. Johnson and Reso, pl. 20, figs. 8, 10-12.

1964 (?) Macropleura? sp. Johnson and Reso, p. 82, pl. 20, figs. 1-7.

This species is characterized by obsolete or nearly obsolete ribbing on the flanks of the valves. A large suite of individuals from Laketown Dolomite unit 48 of Hose in the Confusion Range, Utah (R. K. Hose, written commun., 1954) show a range in dorsal valves from those that are nearly smooth on either side of the fold to those having the fold flanked by a single coarse but subdued rib. In some individuals, the fold itself is rather weak.

The upper Lone Mountain specimens have at least one subdued rib lateral to the fold, and the shell flanks are somewhat less smooth than in Waite's holotype and other Confusion Range specimens. There is no indication of continuous variation from the pauciplicata lineage into coarsely plicated Howellella smithi, also of the upper Lone Mountain.

Occurrence.-Late Silurian, upper part of the Lone Mountain Dolomite; southern Mahogany Hills, locality M1112, associated with Entelophyllum engelmanni and ?Hyattidina sp.f.

\section{Howellella smithi Waite \\ Plate 12, figures 1-19}

1956 Howellella smithi Waite, p. 17, pl. 3, figs. 16-19.

This coarsely ribbed species, large for the genus, is abundantly represented in two fossil localities of the upper Lone Mountain Dolomite of the Fish Creek Range. The hinge line is narrow and the shell width considerably greater than the shell length. Fold and sulcus are prominent, flattened medially toward the commissure. Two coarse costae occupy the flanks of both valves, lateral to which are one or more subdued 
ribs. Dental lamellae are well developed, but only moderately long; there is no suggestion of a pedicle valve median septum. In the brachial valve, the dental rockets and other hinge-plate features are similar to those of Howellella crispa (Hisinger) as illustrated by Hall and Clarke (1894, pt. II, pl. 36, fig. 4). Some individuals of this species, however, reveal a very weak incipient median septum in the brachial valve not known in crispa.

A suite of specimens in various growth stages gives no indication of intergradation of Howellella smithi with pauciplicata of about the same stratigraphic horizon.

Occurrence.-Late Silurian, upper part of the Lone Mountain Dolomite; Southern Fish Creek Range, localities M1087 and M1113. Waite's holotype is reported from Laketown beds "below the Sevy dolomite" in the Pahranagat Range. Howellella smith was not found in unit 48 of the Confusion Range, Utah, Laketown Dolomite which yielded abundant $H$. pauciplicata.

\section{LOCALITY REGISTER ${ }^{1}$}

Fossils of the Rabbit Hill Limestone and correlative strata

Inyo Mountains, Calif.

Locality M1093.-Independence quadrangle, California. NE $1 / 4$ sec. 8, T. 13 S., R. 36 E.; at mouth of Mazourka Canyon east of Kearsarge. At measured stratigraphic section VG-1 (Ross, 1966, pl. 1) 450 feet below top of Vaughn Gulch Limestone.

Locality M1401.-Independence quadrangle, California. Mazourka Canyon area, east side Al Rose Canyon, 6/10 mile N. $78^{\circ}$ E. of SE cor. sec. 36 , T. 11 S., R. 35 E., on measured section SC-5 (Ross, 1966, pl. 1) 40 feet below top of Sunday Canyon Formation.

Monitor Range, Nev. (middle part)

Locality M1311.-East side of Monitor Range near Dobbin Summit, northern Nye County. East side of road east of East Dobbin Summit Spring, altitude 8,500 ft (Army Map Service, Tonopah sheet, NJ 11-5). Lower part of Rabbit Hill Limestone. Same locality as M1067.

Locality M1068. - Same locality as M1311; in middle part of Rabbit Hill Limestone.

Locality M1309.-Same locality as M1311; in upper part of Rabbit Hill Limestone. Same locality as M1069.

Monitor Range, Nev. (northern part)

Locality M409.-Horse Heaven Mountain quadrangle. Southeast side of Rabbit Hill near junction of Whiterock Canyon with Copenhagen Canyon; altitude 7,080 ft. Type section of Rabbit Hill Limestone. Other locality numbers same site: M48, M187, M1326.

Locality M49.-Horse Heaven Mountain quadrangle; $8 / 10$ mile north-northwest of Rabbit Hill; altitude 7,300 ft. Rabbit Hill Limestone with same fauna as type section.

Toquima Range, Nev. (northern part)

Locality M1150.-Wildcat Peak quadrangle. Petes Canyon area, northernmost Toquima Range. SW1/4 sec. 16, T. 16

1Locality numbers with $M$ prefix (for example M1093) used in this report refer to U.S. Geological Survey fossil localities listed in the Paleozoic locality
ledgers of the Menlo Park, Calif. center.
N., R. 46 E.; on top of spur 1,600 feet south of summit 7,188 , and 2,800 feet east of Petes Canyon road. Small isolated exposure of Rabbit Hill Limestone in contact with graptolitic shale. Same locality as M1147.

Simpson Park Range, Nev. (middle part)

Locality M1074.-Walti Hot Springs quadrangle. Foothills half a mile southeast of Walti Ranch and west of McClusky Peak, altitude 6,000 ft. Rabbit Hill Limestone. Simpson Park Range, Nev. (northern part)

Locality M1032.-Horse Creek Valley quadrangle. Coal Canyon area; east side of Coal Canyon in NW1/4 sec. 21, T. 25 N., R. 49 E., altitude 6,600 ft. Rabbit Hill Limestone.

Locality M1075.-Horse Creek Valley quadrangle. Coal Canyon area, near canyon mouth on east side. Limestone beds near top of ridge 6909 on west side. Upper part of Rabbit Hill Limestone.

Locality M1076.-Same as M1075, mostly float material below ridge top 6909 down slope to west. Rabbit Hill Limestone.

Locality M1310.-Horse Creek Valley quadrangle. Coal Canyon area; SE $1 / 4$ sec. 17 , T. 25 N., R. 49 E. West side of ridge 6909 near top. Upper 200 feet of the Rabbit Hill Limestone, in platy limestone with abundant trilobites.

Cortez Mountains, Nev.

Locality M1083.-Cortez quadrangle. Cortez Mountains, southeast side of Mount Tenabo, near head of Horse Canyon, 1,000 feet north, 700 feet west of SE cor. sec. 4, T. 26 N., R. 48 E.; altitude 7,900 ft. Rabbit Hill Limestone fauna.

Tuscarora Mountains, Nev.

Locality M1400.-East side of Tuscarora Mountains near south end (Army Map Service, Winnemucca sheet NK 11-11). Nine miles northwest of Carlin, near top of bluff on east side of Maggie Creek; T. 34 N., R. 51 E. Rabbit Hill Limestone overlying Roberts Mountains Limestone.

Sulphur Spring Range, Nev. (southern part)

Locality M186.-Garden Valley quadrangle. South Mulligan Gulch area; east side South Mulligan Gulch near mouth; 2,000 feet southwest of summit 6927 , altitude 6,560 ft. Beacon Peak Dolomite Member with Rabbit Hill fauna below beds with Oriskany-age fossils, and above probable Lone Mountain Dolomite.

Locality M197.-Garden Valley quadrangle. Bailey Pass area; $3 / 4$ mile south of Bailey Pass on main ridge crest 1,000 feet southeast of summit 7107 . Beds with Rabbit Hill fossils below Oriskany-age faunas of the Nevada Formation.

Locality M1081.-Garden Valley quadrangle. South Mulligan Gulch area; east side of range 1 mile east of Mulligan Gap, 2,600 feet northeast of summit 7446; altitude 6,800 ft. Beacon Peak Dolomite Member with Rabbit Hill fauna.

Locality M1082.-Garden Valley quadrangle. South Mulligan Gulch area; due west of BM 5867, 1\% miles on top of spur, altitude $6,440 \mathrm{ft} ; 1,400$ feet east-northeast of summit 6474. Beacon Peak Dolomite Member with Rabbit Hill fossils.

Locality M1312.-Garden Valley quadrangle. Near M186. Beacon Peak Dolomite Member with Rabbit Hill fossils.

Locality M1319.-Garden Valley quadrangle. Prince of Wales mine area; southeast of Prince of Wales mine and northwest of summit 7530; altitude 7,200 ft. Beacon Hill Dolomite Member with Rabbit Hill fossils, below beds with Oriskany-age fauna.

\section{Fossils of the Lone Mountain Dolomite}

Lone Mountain, Eureka County, Nev. 
Locality M1122.-Whistler Mountain quadrangle. Southeast side Lone Mountain, east side Charcoal Gulch, 4/10 mile due south of summit 7360; altitude $6,840 \mathrm{ft}$ on top of spur. Dark-gray carbonaceous Lone Mountain Dolomite with fragmentary rugose corals.

Locality M1122a.-Same area as M1122, 3,200 ft southsoutheast of summit 7360; altitude 6,600 ft. Dark-gray Lone Mountain Dolomite with fragmentary corals.

Mahogany Hills, Nev. (southern part)

Locality M1112.-Bellevue Peak quadrangle. About 11/4 miles due north of top of Wood Cone Peak and half a mile north-northwest of BM 7201; in foothill exposures of Lone Mountain Dolomite. Altitude 7,300 ft. Dark-gray carbonaceous dolomite with silicified corals.

Fish Creek Range, Nev. (southern part)

Locality M1087.-Bellevue Peak quadrangle. North end of Fenstermaker Mountain on west side at south boundary of quadrangle; about 2,000 feet due south of summit 7232, altitude 7,000 ft. Dark-gray Lone Mountain Dolomite with silicified fossils.

Locality M1113.-Bellevue Peak quadrangle. Same area as M1087; 4/10 mile south-southeast of summit 7232. Altitude 7,080 feet. Dark-gray Lone Mountain Dolomite with silicified fossils.

Sulphur Spring Range, Nev. (southern part)

Locality M1121.-Garden Valley quadrangle. East margin of range in East Ridge, 2 miles south-southwest of Romano Ranch, and $8 / 10$ mile S. $60^{\circ} \mathrm{W}$. of BM 5825; altitude 6,440 ft near top of ridge. Lower part of Lone Mountain Dolomite with silicified corals.

Locality M1148.-Garden Valley quadrangle. East margin of range, east slope of East Ridge in northeast corner sec. 35, T. 23 N., R. 52 E.; half a mile north-northwest of BM 5867 . Altitude $6,100 \mathrm{ft}$ on top east-west spur. Lone Mountain Dolomite with corals.

\section{SELECTED BIBLIOGRAPHY}

Amos, Arturo, and Boucot, A. J., 1963, A revision of the brachiopod family Leptocoeliidae: Palaeontology, v. 6, pt. 3, p. $440-457$, pls. $62-65$.

Amsden, T. W., 1949, Stratigraphy and paleontology of the Brownsport formation (Silurian) of western Tennessee: Yale Univ. Peabody Mus. Nat. History Bull. 5, p. 1-138, 34 pls., text figs.

1951, Brachiopods of the Henryhouse Formation (Silurian) of Oklahoma: Jour. Paleontology, v. 25, p. 69-96, pls. 15-20, text-fig.

1958a, Haragan articulate brachiopods, pt. 2 of Amsden, T. W., and Boucot, A. J., Stratigraphy and paleontology of the Hunton group in the Arbuckle Mountain region: Oklahoma Geol. Survey Bull. 78, p. 1-144, 14 pls., text figs.

$1958 \mathrm{~b}$, Supplement to the Henryhouse brachiopods, pt. 3 of Amsden, T. W., and Boucot, A. J., Stratigraphy and paleontology of the Hunton group in the Arbuckle Mountain region: Oklahoma Geol. Survey Bull. 78, p. 145-157, pls. 12, 14, text figs.

1958c, Stratigraphy and paleontology of the Hunton group in the Arbuckle Mountain region, pt. V, Bois D'Arc articulate brachiopods: Oklahoma Geol. Survey Bull. 82, 110 p., 5 pls.

Amsden, T. W., and Ventress, W. P. S., 1963, Early Devonian brachiopods of Oklahoma; pt. 1, Articulate brachiopods of the Frisco formation (Devonian): Oklahoma Geol. Sur- vey Bull. 94, p. 9-140, pls. 1-12.

Beecher, C. E., 1893a, The development of a Paleozoic poriferous coral: Connecticut Acad. Arts and Sci. Trans., v. 8, pt. 2, p. 207-214, pls. 9-13.

-1893 b Symmetrical cell development in the Favositidae: Connecticut Acad. Arts and Sci. Trans., v. 8, pt. 2, p. 215218 , pls. $14 ; 15$.

Boucot, A. J., 1957, Revision of some Silurian and Early Devonian spiriferid genera and erection of Kozlowskiellinae, new subfamily: Senckenbergiana Lethaea, v. 38, no. 5-6, p. 311-334, 3 pls.

1958, Kozlowskiellina, new name for Kozlowskiella Boucot, 1957: Jour. Paleontology, v. 32, no. 5, p. 1030.

1960, Brachiopods, in Boucot, A. J., Martinsson, Anders, Thorsteinsson, R., Walliser, O. H., Whittington, H. B., and Yochelson, Ellis, A Late Silurian fauna from the Sutherland River Formation, Devon Island, Canadian Arctic Archipelago: Canada Geol. Survey Bull. 65, 51 p., 10 pls.

Boucot, A. J., and Amsden, T. W., 1958, New genera of brachiopods, pt. 4 in Amsden, T. W., and Boucot, A. J., Stratigraphy and paleontology of the Hunton group in the Arbuckle Mountain region: Oklahoma Geol. Survey Bull. 78 , p. 159-170, pl. 14, text figs.

Boucot, A. J., and Gill, E. D., 1956, Australocoelia, a new Lower Devonian brachiopod from South Africa, South America, and Australia: Jour. Paleontology, v. 30, no. 5, p. 1173-1178, pl. 126.

Boucot, A. J., Johnson, J. G., Harper, Charles, and Walmsley, V. G., 1966, Silurian brachiopods and gastropods of southern New Brunswick: Canada Geol. Survey Bull. 140, 45 p., 18 pls.

Boucot, A. J., Johnson, J. G., and Staton, R .D., 1964, On some atrypoid, retzioid, and athyridoid Brachiopoda: Jour. Paleontology, v. 38, no. 5, p. 805-822, pls. 125-128.

Butler, A. J., 1935, On the Silurian coral Cyathaxonia siluriensis M'Coy: Geol. Mag., v. 72, p. 116-124, pl. 2.

Clark, D. L., and Ethington, R. L., 1964, Age of the Roberts Mountains formation (Silurian?) in the Great Basin: Geol. Soc. America Bull., v. 75, p. 677-682.

1966, Conodonts and biostratigraphy of the Lower and Middle Devonian of Nevada and Utah: Jour. Paleontology, v. 40 , no. 3 , p. $659-689$, pls. 82-84.

Cooper, G. A., 1942, New genera of North American brachiopods: Washington Acad. Sci. Jour., v. 32, p. 228-235.

1944, Brachiopoda, in Shimer, H. W., and Shrock, R. R., eds., Index fossils of North America: Cambridge, Mass., The Technology Press, Mass. Inst. Technology (New York, John Wiley and Sons, Inc.), p. 277-365, pls. 105-143.

Delo, D. M., 1940, Phacopid trilobites of North America: Geol. Soc. America Spec. Paper 29, 135 p., 13 pls.

Dunbar, C. O., 1918, Stratigraphy and correlation of the Devonian of western Tennessee: Am. Jour. Sci., v. 46, p. 732755 .

1920, New species of Devonian fossils from western Tennessee: Connecticut Acad. Arts and Sci. Trans., v. 23, p. 113-149, pls. 1-5.

Duncan, Helen, 1956, Ordovician and Silurian coral faunas of western United States: U.S. Geol. Survey Bull. 1021-F, p. 209-236, pls. 21-27.

Edwards, H. M., and Haime, Jules, 1850-1854, A monograph of the British fossil corals: London, Palaeontographical Soc., 322 p., 72 pls.

-1851, Monographie des polypiers fossiles des terrains palaeozoiques: Mus. Histoire Nat., Paris, Archives, v. 5, 
502 p., 20 pls.

Etheridge, Robert, Jr., 1911, The Lower Palaeozoic corals of Chillagoe and Clermont, pt. 1: Queensland Geol. Survey Pub. 231, p. 1-8, pls. A-D. [Australia]

Fenton, C. L., and Fenton, M. A., 1936, The "tabulate" corals of Hall's "Illustrations of Devonian fossils": Carnegie Mus. Annals, v. 25, art. 5, p. 17-56, pls. 1-7.

Flügel, H., and Free, B., 1962, Laccophyllidae (Rugosa) aus dem Greifensteiner Kalk (Eiflium) von Wiede bei Greifenstein: Palaeontographica, v. 119, no. A, p. 222-247.

Gilluly, James, and Masursky, Harold, 1965, Geology of the Cortez quadrangle, Nevada: U.S. Geol. Survey Bull. 1175, $117 \mathrm{p}$.

Hague, Arnold, 1892, Geology of the Eureka district, Nevada: U.S. Geol. Survey Mon. 20, 419 p. (with atlas), 8 pls.

Hall, James, 1859-1861, Organic remains of the lower Helderburg group and the Oriskany sandstone: New York Geol. Survey, Palaeontology, v. 3, p. 1-532, pls. 1-120.

1887, Corals and Bryozoa: New York Geol. Survey, Palaeontology, v. 6, p. 1-298, pls. 1-66.

Hall, James, and Clarke, J. M., 1892, An introduction to the study of the genera of Palaeozoic Brachiopoda: Palaeontology of New York, v. 8, pt. 1, p. 1-367, 20 pls., text figs. [1893].

-1894, An introduction to the study of the genera of Palaeozoic Brachiopoda: Palaeontology of New York, v. 8, pt. 2, p. 1-314, pls. 21-84, text figs.

Havlicek, Vladimir, 1959, Spiriferidae of the Silurian and Devonian of Bohemia: Rozpravy Ústřed. Ustavu Geol., v. 25, p. 1-218 (Czech text), p. 223-275 (English summary), 27 pls., text figs.

-1961, Rhynchonelloidea des böhmischen älteren Paläozoikums (Brachiopoda) : Roszpravy Ústřed. Ustavu Geol., v. 27, p. 1-211, pls. 1-27.

Helmbrecht, W., and Wedekind, Rudolf, 1923, Versuch einer biostratigraphischen gliderung der Siegener Schichten auf grund von Rensselaerien und Spiriferen: Glückauf, v. 59, no. 41, p. 949-953.

Hill, Dorothy, 1935, British terminology for rugose corals: Geol. Mag., v. 72, no. 857, p. 481-519.

1936, The British Silurian rugose corals with acanthine septa: Royal Soc. London Philos. Trans., ser. B, no. 534, v. 226 , p. $189-217,2$ pls.

1940, The Silurian Rugosa of the Yass-Bowning District, N.S.W.: Linnean Soc. New South Wales Proc., v. 65, pt. $3-4$, p. 388-420, 3 pls.

1956, Rugosa, in Moore, R. C., ed., Treatise on invertebrate paleontology, Part F-Coelenterata: New York and Lawrence, Kansas, Geol. Soc. America and Kansas Univ. Press, p. F233-F324.

1958, Distribution and sequence of Silurian coral faunas: Royal Soc. New South Wales Jour. and Proc., v. 92, pt. 4, p. 151-173.

Hill, Dorothy, and Stumm, E. C., 1956, Tabulata, in Moore, R. C., ed., Treatise on invertebrate paleontology, part FCoelenterata: New York and Lawrence, Kansas, Geol. Soc. America and Kansas Univ. Press, p. F444-F477.

Hudson, R. G. S., 1944, Lower Carboniferous corals of the genera Rotiphyllum and Permia: Jour. Paleontology, v. 18 , no. 4, p. 355-362, pls. 56, 57.

Johnson, J. G., 1965, Lower Devonian stratigraphy and correlation, northern Simpson Park Range, Nevada: Canadian Petroleum Geology Bull., v. 13, no. 3, p. 365-381.

-1970, Great Basin Lower Devonian Brachiopoda: Geol.
Soc. America Mem. 121, 421 p., 74 pls.

Johnson, J. G., and Boucot, A. J., 1968, Brachiopods of the Bois Blanc Formation in New York: U.S. Geol. Survey Prof. Paper 584-B, p. 1-27, 8 pls.

Johnson, J. G., and Murphy, M. A., 1969, Age and position of Lower Devonian graptolite zones relative to the Appalachian standard succession: Geol. Soc. America Bull., v. 80, no. 7 , p. 1275-1282.

Johnson, J. G., and Reso, Anthony, 1964, Probable Ludlovian brachiopods from the Sevy dolomite of Nevada: Jour. Paleontology, v. 38, no. 1, p. 74-84, pls. 19, 20.

Johnson, J. G., and Talent, J. A., 1967a, Muriferella, a new genus of Lower Devonian septate dalmanellid: Royal Soc. Victoria Proc., v. 80, pt. 1, p. 43-50, pls. 9, 10.

-1967b, Cortezorthinae, a new subfamily of Siluro-Devonian dalmanellid brachiopods: Palaeontology, v. 10, pt. 1, p. $142-170$, pls. 19-22.

Kay, Marshall, and Crawford, J. P., 1964, Paleozoic facies from the miogeosynclinal to the eugeosynclinal belt in thrust slices, Central Nevada: Geol. Soc. America Bull., v. 75 , p. $425-454$.

Kindle, E. M., 1912, The Onondaga fauna of the Allegheny region: U.S. Geol. Survey Bull. 508, 144 p., 13 pls.

Klapper, Gilbert, 1968, Lower Devonian conodont succession in central Nevada [abs.]: Geol. Soc. America 64th Ann. Mtg., Cordilleran Section, Tucson, 1968, program, p. 72-73.

Klapper, Gilbert, and Ormiston, A. R., 1969, Lower Devonian conodont sequence, Royal Creek, Yukon Territory and Devon Island, Canada; with a section on Devon Island stratigraphy: Jour. Paleontology, v. 43, no. 1, p. 1-27, 6 pls.

Kozlowski, Roman, 1929, Les brachiopodes de la Gothlandiens de la Podolie Polonaise: Palaeontologia Polonica, v. 1, p. 1-254, 12 pls., text figs.

1946, Howellella, a new name for Crispella Kozlowski 1929: Jour. Paleontology, v. 20, p. 295.

Lang, W. D., and Smith, Stanley, 1927, A critical revision of the rugose corals described by W. Lonsdale in Murchison's "Silurian System": Geol. Soc. London Quart. Jour., v. 83, p. 448-491, pls. 34-37.

Lang, W. D., Smith, Stanley, and Thomas, H. D., 1940, Index of Palaeozoic coral genera: London, British Mus. (Nat. History), 231 p.

Lindström, Gustav, 1882, Silurische Korallen aus NordRussland und Siberien: Kgl. Svenska Vetenskapsakad. Handl., Bihang, v. 6, no. 18, 23 p., 1 pl.

McAllister, J. F., 1952, Rocks and structure of the Quartz Spring area, northern Panamint Range, California: California Div. Mines Spec. Rept. 25, 38 p.

McKee, E. H., Merriam, C. W., and Berry, W. B. N., 1972, Biostratigraphy of the Tor and McMonnigal Formations, Toquima Range, Nevada: Am. Assoc. Petroleum Geologists Bull., v. 56, no. 8, p. 1563-1570.

McKee, E. H., and Ross, R. J., Jr., 1969, Stratigraphy of eastern assemblage rocks in a window in Roberts Mountains thrust, northern Toquima Range, central Nevada: Am. Assoc. Petroleum Geologists Bull., v. 53, no. 2, p. 421-429.

Merriam, C. W., 1940, Devonian stratigraphy and paleontology of the Roberts Mountains region, Nevada: Geol. Soc. America Spec. Paper 25, 114 p., 16 pls.

1963, Paleozoic rocks of Antelope Valley, Eureka and Nye Counties, Nevada: U.S. Geol. Survey Prof. Paper $423,67 \mathrm{p}$.

1973a, Silurian rugose corals of the central and southwest Great Basin: U.S. Geol. Survey Prof. Paper 777, 65 p. 
1973b, Lower and lower Middle Devonian rugose corals of the central Great Basin: U.S. Geol. Survey Prof. Paper 805 (in press).

1973c, Middle Devonian rugose corals of the central Great Basin: U.S. Geol. Survey Prof. Paper 799, 52 p.

Merriam, C. W., and Anderson, C. A., 1942, Reconnaissance survey of the Roberts Mountains, Nevada: Geol. Soc. America Bull., v. 53, p. 1675-1728.

Nolan, T. B., Merriam, C. W., and Williams, J. S., 1956, The stratigraphic section in the vicinity of Eureka, Nevada: U.S. Geol. Survey Prof. Paper 276, 77 p.

Norford, B. S., 1962, The Silurian fauna of the Sandpile group of northern British Columbia: Canada Geol. Survey Bull. 78,51 p., 16 pls.

Oliver, W. A., Jr., 1960, Rugose corals from reef limestones in the Lower Devonian of New York: Jour. Paleontology, v. 34 , no. 1 , p. $59-100$, pls. 13-19.

1962, Silurian rugose corals from the Lake Temiscouata area, Quebec: U.S. Geol. Survey Prof. Paper 430-B, p. 11-19, pls. 5-8.

1966, Description of dimorphism in Striatopora flexuosa Hall: Paleontology, v. 9, pt. 3, p. 448-454, pls. 68-71.

Počta, Philippe, 1902, Anthozoaires et Alcyonaires, in Barrande, Joachim, System Silurien du centre de la Boheme: Prague, Recherches Paleontologiques, v, 8, pt. 2, 347 p., 99 pls.

Prantl, Ferdinand, 1938, Some Laccophyllidae from the Middle Devonian of Bohemia: Annals and Mag. Nat. History, 11th ser., v. 2, p. 18-41, pls. 1-3.

1940, Korallengattung Xylodes Lang and Smith im böhmischen Silur: Czechoslovakia, Akad. Wiss. Mitt., Prague, 21 p., 3 pls.

Ross, D. C., 1966, Stratigraphy of some Paleozoic formations in the Independence quadrangle, Inyo County, California: U.S. Geol. Survey Prof. Paper 396, 64 p., illus.

Rukhin, L. B., 1938, The lower Paleozoic corals and stromatoporoids of the upper part of the Kolyma river: U.S.S.R., State Trust Dalstroy, Contr. Knowledge of KolymaIndighirka, Geol. and Geomorph., fasc. 10, 119 p., 28 pls. [Russian, English summary].

Sardeson, F. W., 1896, Ueber die Beziehungen der fossilen Tabulaten zu den Alcyonairen: Neues Jahrbuch für Mineralogie, Geologie und Paläontologie, v, 10, p. 249-362.

Schindewolf, O. H., 1942, Zur Kenntniss der Polycoelien und Plerophyllen: Abh. Reichsamt. Bodenf., Neue Folge, Heft. 204, 324 p., 36 pls.

Schmidt, Herta, 1941, Die mittel devonischen Rhynchonelliden der Eifel: Abh. senckenberg. naturf. Gesell. 459, p. 1-79, pls. 1-7.

Schouppé, Alexander, 1950, Kritische Betrachtungen zu den Rugosengenera des Formenkreises Tryplasma Lonsd., Polyorophe Lindstr.: Österreich. Akad. Wiss. Sitzungsber. Math.-Naturw. Kl., div. 1, v. 159, p. 75-85.

Schuchert, Charles, 1897, A synopsis of American fossil Brachiopoda including bibliography and synonymy: U.S. Geol. Survey Bull. 87, p. 1-464.

1913, Brachiopoda, in Textbook of Paleontology: Eastman-Zittel, Macmillian and Co., p. 355-420.

Schuchert, Charles, and Cooper, G. A., 1931, Synopsis of the brachiopod genera of the suborders Orthoidea and Pentameroidea, with notes on the Telotremata: Am. Jour. Sci., ser. 5, v. 22, p. 241-251.

1932, Brachiopod genera of the suborders Orthoidea and Pentameroidea: Yale Univ. Peabody Mus. Nat. History,
Mem.,v. 4, pt. 1, p. 1-270, 29 pls., text figs.

Schuchert, Charles, and Maynard, T. P., 1913, Brachiopoda, in Lower Devonian of Maryland: Maryland Geol. Survey, p. 290-450, pls. $1-98$.

Simpson, G. B., 1900, Preliminary descriptions of new genera of Paleozoic rugose corals: New York [State] State Mus. Bull. 39, v. 8, p. 199-222; republished as New York State Univ., New York State Mus. 54th Ann. Rept. of Regents, 1900, v. 3.

Smith, Stanley, 1930, Some Valentian corals from Shropshire and Montgomeryshire, with a note on a new stromatoporoid: Geol. Soc. London Quart. Jour., v. 86, p. 291-330, pls. 26-29.

1933, On Xylodes rugosus sp. nov., a Niagaran coral: Am. Jour. Sci., ser. 5, v. 26, no. 155, p. 512-522, 1 pl.

1945, Upper Devonian corals of the Mackenzie River region, Canada: Geol. Soc. America Spec. Paper 59, 126 p., 35 pls.

Smith, Stanley, and Tremberth, Reginald, 1929, On the Silurian corals Madreporites articulatus Wahlenberg, and Madrepora truncata $L$ : Annals and Mag. Nat. History, ser. 10 , v. 3, p. $361-376$, pls. 7,8 .

Soshkina, E. D., 1937, Corals of the Upper Silurian and Lower Devonian of the eastern and western slopes of the Urals: Akad. Nauk SSSR, Paleozool. Inst. Trudy, v. 6, pt. 4, 112 p., 21 pls. [Russian, English summary].

Stainbrook, M. A., 1946, Corals of the Independence shale of Iowa: Jour. Paleontology, v. 20, no. 5, p. 401-427, pls. 57-61.

Stehli, F. G., 1954, Lower Leonardian Brachiopoda of the Sierra Diablo: Am. Mus. Nat. History Bull. v. 105, art. 3, p. 261-357, pls. 17-27, text figs.

Stumm, E. C., 1949, Revision of the families and genera of the Devonian tetracorals: Geol. Soc. America Mem. 40, 92 p., 25 pls.

-1950, Corals of the Devonian Traverse group of Michigan; pt. 3, Antholites, Pleurodictyum, and Procteria: Michigan Univ. Mus. Paleontology Contr., v. 8, no. 8, p. 205-220, 5 pls.

1952, Species of the Silurian rugose coral genus Tryplasma from North America: Jour. Paleontology, v. 26, no. 5 , p. 841-843, pl. 125 .

1954, Lower Middle Devonian phacopid trilobites from Michigan, - southwestern Ontario, and the Ohio Valley: Michigan Univ. Mus. Paleontology Contr., v. 11, no. 11, p. 201-221, 4 pls.

1962, Silurian corals from the Moose River synclinorium, Maine, chap. A in Silurian corals from Maine and Quebec: U.S. Geol. Survey Prof. Paper 430, p. 1-9, pls. 1-4 [1963]. 1964, Silurian and Devonian corals of the Falls of the Ohio: Geol. Soc. America Mem. 93 ,184 p., 2 figs., 80 pls.

Stumm, E. C., and Tyler, J. H., 1964, Corals of the Traverse group of Michigan, Part 12, The small-celled species of Favosites and Emmonsia: Michigan Univ. Mus. Paleontology Contr., v. 19, no. 3, p. 23-26, pls. 1-7.

Swann, D. H., 1947, The Favosites alpenensis lineage in the Middle Devonian Traverse group of Michigan: Michigan Univ. Mus. Paleontology Contr., v. 6, no. 9, p. 235-318, pls. $1-17$.

Swartz, F. M., 1930, The Helderberg group of parts of West Virginia and Virginia: U.S. Geol. Survey Prof. Paper 158-C, p. 27-75, pls. 6-9, text figs.

1939, The Keyser limestone and Helderberg group, in The Devonian of Pennsylvania: Pennsylvania Geol. Survey Bull., 4th ser., G19, p. 29-91, text figs. 
Waite, R. H., 1956, Upper Silurian Brachiopoda from the Great Basin: Jour. Paleontology, v. 30 , no. 1, p. 15-18, pl. 4.

Walcott, C. D., 1884, Paleontology of the Eureka district [Nevada]: U.S. Geol. Survey Mon. 8, 298 p., 24 pls.

Wedekind, Rudolf, 1927, Die Zoantharia von Gotland: Sveriges Geol. Undersökning, ser. Ca, no. 19, p. 1-94, 30 pls.

Whittington, H. B., 1956, Type and other species of Odontopleuridae (Trilobita): Jour. Paleontology, v. 30, p. 504520 , pls. $57-60$.
Williams, Alwyn, and Wright, A. D., 1963, The classification of the "Orthis testudinaria Dalman" group of brachiopods: Jour. Paleontology, v. 37, no. 1, p. 1-32, pls. 1, 2.

1965, Orthida, in Williams, Alwyn, and others, Brachiopoda, pt. H, of Moore, R. C., Treatise on invertebrate paleontology: Geol. Soc. America and Kansas Univ. Press, 927 p., illus.

Winterer, E. L., and Murphy, M. A., 1960, Silurian reef complex and associated facies, central Nevada: Jour. Geology, v. 68, no. 2 , p. 117-139, 7 pls. 


\section{INDEX}

[Italic page numbers indicate both major references and descriptions]

\begin{abstract}
A
\end{abstract}
Page

abditum, Endophyllum.

Abstract

Acanthoscapha sp

Acidaspis tuberculatus

Acknowledgements

Acodina

Acrospirifer. kleinhampli

kobehana murchisoni

sp. D

sp 23

1
11

11

36

2

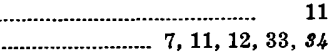
$7,8,10,12,34 ; \mathrm{pl} .7$ $28,29,34$

34

pl. 7

, 9, 10; pl. 7

(Acrospirifer), Hysterolites ....................... 33, 34

acuaria, Nowakia ..................................... 35

acuminatum, Laccophyllum ...................... 22

acuticuspidata, Leptaena ........................... 28

acutiplicata, Anoplotheca .......................... 31 Leptocoelia

Aechmina sp

aequabile, Tryplasma .................................. 37

affinis, Billingsastraea .......................................

Alleynia ................................................... 21, 22

(Nicholsonia) ....................................... 21, 22

alpenesis, Favosites .................................. 19

altera, Plethorhyncha ................................ 30

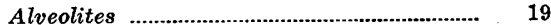

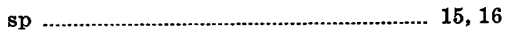

Ambocoelia ............................................... 30

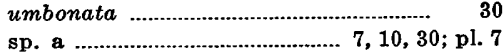
Ambocoeliidae ........................................ 30 Anastrophia ........................................ 10, 11, 29

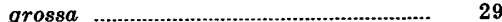
verneuili ................................ 10, 11, 29; pl. 5 andersoni, Plethorhyncha ......... 7, 8, 29, 30; pl. 6 Anoplotheca acutiplicata ............................. 31 sp ................................................... 31 antelopensis, Levenea subcarinata............ 7, 8, 10, 11,$26 ;$ pl. 4

Antelope-Roberts Mountains facies belt.... 5, 11 arcuata, Meristella

Areal distribution

5

.... 11, 12, 34, 35 dobbinensis, Costispirifer ................. 7, 8, 12,

planicostatus, Costispirifer $\quad 35 ;$ pl. 7

Spirifer ............................................. 34

Articulata ................................................ 25, 40

articulatum, Entelophyllum ….................. 38

articulatus, Madreporites ............................ 38 Xylodes

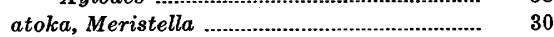

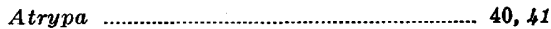
tennesseensis ......................................... 41 sp. f ......................... 16, 41; 11 sp .................................................... 41

Atrypella carinata .................................... 16, 41

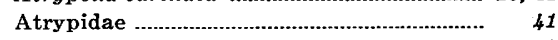

Australocoelia ......................................................

Australophyllum ................................. 11, 2s, 24 cyathophylloides ................................. 24 landerensis ...................... 8, 11, 24, 25; pl. 9 stevensi ............................... 11, 24, 25, pl. 9

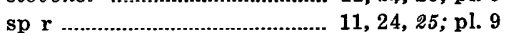

B Page

Bailey Pass ............................................... 10 Bairdia leguminoides

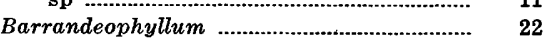
perplexum ................................................. 22

barrandi, Plethorhyncha ........................ $\quad 30$

becki tennesseensis, Leptostrophia ....... 7, 8, 27; pls. 3,8

Belodella resimus

11

$\begin{array}{lr}\text { Berdan, Jean M., quoted................................ } & 11 \\ \text { bieniaszi, Camarotoechia } & \text {............................. }\end{array}$

Billingsastraea ..................................... 25

affinis ......................... 25

nevadensis .......................................... 25

sp. m ............................. 9, 10, 11, 25; pl. 9

birdsongensis, Phacops 37

Birdsong Shale, Tennessee............................. $\quad 27$

Bogoslovsk, Russia …............................................. 37

Bois d'Arc Limestone, Oklahoma......... 27, 28, 33

Borszezow beds, Poland....................... 40

bowerbanki, Endophyllum .......................... 23

Brachiopoda ...........................................25,40

brachiopods ..................... 2, 7, 10, 11, 17, 18, 35

Branik Limestone, Bohemia ..................... 22

bransoni, Strophonella ................................ 28

Brownsport Formation .............................. 21, 41

\section{C}

Camarotoechia

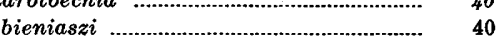

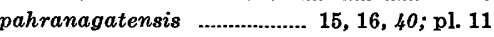
sp.b .................................. 15, 16, 40; pl. 11 sp. $f$...................................... 15, 16, 40; pl. 11 sp ....................................... 14, 16; pl. 11

Camarotoechiidae ...................................... 40

canadensis, Phacops ........................... 9, s7, pl. 2 carinata, Atrypella ...................................... 41 catenulatus, Halysites ................................ 13

Chewelah area, Stevens County, Wash....... 12

Chronophyllum ............................................ 12

Cladopora ................................................. 19

Coal Canyon ...................... 4, 8, 11, 12, 35, 36, 37 fault zone

Coblenz and Eifel districts, Germany......... 20

Coelospira ............................................... 9

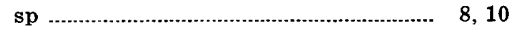

Coenites

Conclusions .

congesta, Hyattidina

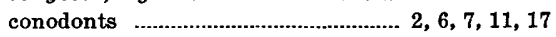

Conularia ............................................ 8, 10, 19, 35

huntiana ......................... 8, 10, 19, $85 ; \mathrm{pl} .2$

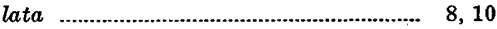

sp .......................................................... $85 ; 8$

Conulariidae ................................................... 35

conularids .................................................... 19, 35

Conulata.

convexoris, Parahealdia

Cooper, G. A., quoted

cooperi, Trematospira .......................................

Copenhagen Canyon, Horse Heaven

Mountain quadrangle ............. 6

coral-brachiopod assemblages ........................ 15
Page

corals ........................................... 2, 13, 15, 19

Coral Zones .................................................... 18

Cordilleran geosyncline ............................... 4, 5, 6

Cortez Mountains .............................. 2, 9, 21,42

Costellirostra ........................................... $\quad 30$

Costispirifer ..................................... 7, 11, 34,35 arenosus .................................. 11, 12, 34, 35 dobbinensis ............ 7, 8, 10, 12, 35; pl. 7 planicostatus ..................................... 34

planicostatus .............................................. 34

Costispiriferidae ..................................... 34

crassiformis, Salopina ............................... $\quad 40$

$\begin{array}{lr}\text { crinoidal debris } & \text {............................................ } \\ \text { crispa, Howellella } & \mathbf{4 2}\end{array}$

Cyathaxonia siluriensis .............................. 21, 22

cyathophylloides, Australophyllum ........... $\quad 24$

Spongophyllum ............................... 23, 24 cycloptera monitorensis, Howellella....... 7, 8, 11,

Howellella

$33 ; \mathrm{pl} .8$

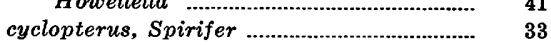

D

Dalmanella sp

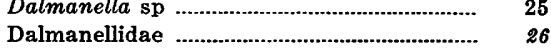

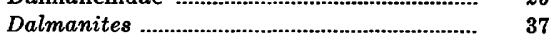

dalmanitid ................................................. 9, 10

Dalmanitidae .................................................. $\quad 37$

Delthyrididae .................................................. 32,41

Delthyris ..................................................... 32

raricosta ..................................................... 32

Devils Gate Limestone................................... 9, 15

Devon Island, Northwest Territories,

Canada ..................................... 40

deweyi, Trematospira ............................... $\quad 32$

diana, Plethorhyncha ................................. $\quad 30$

Disphyllidae ……........................................... 25

Disphyllum …............................................. 38

dobbinensis, Costispirifer arenosus ........ 7, 8, 12,

s5; pl. 7

Dobbin Summit

Douvillina geniculata

dunbari, Pleurodictyum ................. 7, 20, 21; pl. 1

$\mathbf{E}$

Ely Springs Dolomite

Emmonsia

Endophyllidae

Endophyllum

abditum

bowerbanki

engelmanni, Entelophyllum .............. 14, s8, 41;

pls. 10, 11

engelmanni b, Entellophyllum .................. 15, 89

Enteletidae

Entelophylloides ...

Entelophyllum ......................... 3, 13, 14, 16, 18, 38 articulatum ........................................ 38 engelmanni ............ 14, 16, 38,41 , pls. 10,11

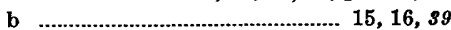
eurekaensis ................................ 10, 15, $39 ; \mathrm{pl} .10$

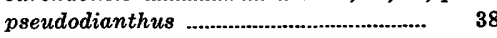
sp 
Page

Entelophyllum-Howellella assemblages 15, 16, 17 equistriata, Trematospira ........................ 31, 32 eurekaensis, Entelophyllum ........... 15, s9; pl. 10 Eureka mining district ..................... 1, 2, 3, 10

\section{F}

Favosites ..................................... 6, 7, 8, 10, 19 alpenesis .................................................. 19 gothlandicus ........................................... 19 helderbergiae ................... $6,7,8,10,19 ; \mathrm{pl} .1$ sp ...................................................... 9, 10

Favositidae

favositids ....................................................... 15, 16

Favositinae ................................................. 19

Ferganella lincolnensis ................................ 40

Fish Creek Range .........................15, 38, 40, 43 Fish Haven Dolomite ................................. 16 flabellites, Leptocoelia ................................ 31 flexuosa, Striatopora .............................. 20 foerstei, Syringaxon ........ 7, 8, 9, 10, 11, 22; pl. 2 fremonti, Leptaena .............. 7, 8, 9, 10, 28; pl. 3 Frisco Limestone, Oklahoma ...................... 28

$\begin{array}{lrr}\text { fucoids . . } & 7 \\ \text { furca, Thlipsura }\end{array}$

G

gaspensis, Phacops ........................................ Gazelle Formation, Klamath Mountains .... 23 geniculata, Douvillina ............................... 16 Giles Formation, Virginia ........................... Glassia variabilis

gothlandicus, Favosites ................................ 19 Gotland, Sweden ............................................ 38 graptolites

Great Basin Silurian and Devonian depositional systems of ............................ 1, 2, 4 Early Devonian coral zone B 7, 10, 12, 18, 28 Early Devonian coral zone C .............. 18, 28 Late Silurian coral zone D ........ 4, 8, 16, 18 Late Silurian coral zone $\mathbf{E}$...... 4, 6, 7, 8, 11, $12,16,18,19,24$

Middle Devonian coral zone F .......... 18, 19 Silurian basal chert ............................... Greifensteiner Kalk, Germany .................... grossa, Anastrophia .................................... 29 gwenensis, Striatopora ................... 6, 8, 20; pl. 1

$\mathbf{H}$

Halysites $13,15,16$ catenulatus ...................................... 13 Halysites-pycnostylid biofacies .................. 15, 16 Halysitidae .............................................. 19 Hamilton Group ................................................. 20 Hanson Creek Limestone ......................... 3, 13 Haragan Limestone, Oklahoma ................ 26, 28 haraganensis, Schuchertella ..... 7, 8, 9, 29; pl. 3 Hedeina .............................................. 32 helderbergiae, Favosites ........... 6, 7, 8, 19; pl. 1 Heliolitidae ................................................. 19 Henryhouse Formation ............................. 26, 41 henryhousensis, Rhipidomella ................... 26 hesperalis, Hyattidina ................................ 40 hexactinellid sponge spicules ........................ 7 Hidden Valley Dolomite, Panamint Mountains, Calif .............. 22, 34, 35 Hindella ..................................................40, 41 prinstana ............................................... 41 umbonata ............. 41 sp. a .............................. 15, 16, 41; pl. 12 History of investigation ........................... 9 Howellella ........................... 3, 15, 18, $33,38,41$ crispa .......................... 42 cycloptera .

monitorensis $7,8,10,11,33$. pl 8 pauciplicata ............. 14, 16, 33, 41, 42; pl. 12 smithi .................... 15, 16, 33, 41, 42; pl. 12
Howellella-Camarotoechia-Atrypa

brachiopod assemblage

huddlei, Icriodus latericrescens

Huddle, J. W., quoted .

Hunsrückschiefer Formation, Germany

huntiana, Con

Hyattidina

congesta

40

hesperalis _................................... 16, 40

sp. f ............................ 14, 15, 16, 40,41; pl. 12

sp .................................................... pl. 12

Hysterolites (Acrospirifer)

\section{I}

Icriodus

$$
\text { huddlei }
$$

sp Canyon

Independence Shale, Iowa

infrequens, Leptocoelia

Introduction

Inyo Mountains, Calif

kleinhampli, Acrospirifer .... 7, 8, 10, 12, s4; pl. 7

Kobeh Valley project ................................ 2, 10

kobehana, Acrospirifer ....................... 28, 29, 34

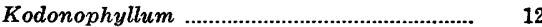

strawi

Kozlowskiellina

nolani

strawi

velata

sp. a

Kyphophyllidae

Kyphophyllum

lindstromi

Laccophyllidae

Laccophyllum

acuminatum

laevis, Meristella

Laketown Dolomite, Confusion Range,

Utah ...................... 4, 16, 18, 40, 41

landerensis, Australophyllum ........ 8, 11, 24; pl. 9

lata, Conularia

latericrescens huddlei, Icriodus

B, Icriodus

lenticularis, Pleurodictyum ........ 9, 12, 19, 20, 21

Leonaspis .......................... $7,8,9,10,11,36,37$ tuberculatus ......................... 7, 8, 9, 10,11, $s 6$ williamsi

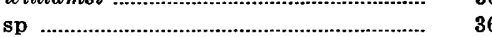

Leptaena acuticuspidata .......................................... 28 fremonti ....................... 7, 8, 9, 10, 28; pl. 3 rhomboidalis .......................................... 28

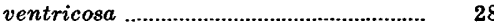

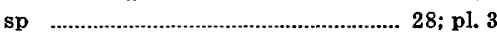
Leptaenidae .................................................. 28

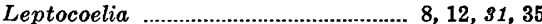
acutiplicata ............................................. 31 flabellites

infrequens occidentalis ................... 7, 8, 10, 11, 31 ; pl. 5 sp …................................. 8, 9, 10,31, 35 Leptocoeliidae .............................................. $s 1$

Leptostrophia becki tennesseensis ........ $7,8,10,27$; pls. 3,8 sp …............................. $7,10,27$; pls. 3,8

Levenea subcarinata
antelopensis .............. $7,8,10,11,26 ;$ pl. 4 lincolnensis, Ferganella

lindströmi, Kyphophyllum

Locality register

logani, Phacops

Lone Mountain

$1,3,12,13,42$ Lone Mountain Dolomite..... 2, 10, 12, 13, 15, 16,

age and correlation of $17,33,38,40$ fossils of $4,16,17,18,19,42$ relation to Rabbit Hill Limestone .... 3, 17

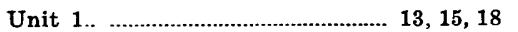

Unit $2 \quad 13,15,16,18$ Lone Mountain Formation ....................... 3, 12 Lone Mountain-Laketown biofacies ......... 15, 16, 18,41

Lone Mountain Limestone ........................ 3, 13 lykophyllids

mcbridei, Trematospira ................ 7, 31,32; pl. 6 McClusky Peak

Macropleura

Madreporites articulatus ............................. 38

Mahogany Hills ........................................ 1s, 40, 43 martini, Meristella ..................... 7, 8, 10, $30 ;$ pl 7.

Meristella

arcuata

atoka

laevis

martini

robertsensis

sp

Meristellidae

Meristina sp ...

Mesomphalus sp

Methods

Michelinia

$$
\text { sp }
$$

Micheliniinae

Miraspis

p

pea , $8,11,8 s_{0}$

Monitor Range pl. 8

type area 2

Monitor-Simpson Park belt .......................... 4, 5,

Monograptus

Mucophyllum

Mulligan Gap fault

Mulligan Gulch

multistriata, Trematospir

murchisoni, Acrospirifer

Murifella

musculosa, Rhipidomella

la

$\mathbf{N}$

Neomphyma $\mathbf{N}$

Nevada Formation

$2,6,13,17,19,31$ 17,18 fossils $3,5,6,19$ unit 1 ... $6,7,10,12,17,27,28,29,34,35,36$ unit $2 \ldots \ldots \ldots \ldots \ldots . . . . .19,22,29,35,36,37$ unit 4

nevadensis, Billingsastraea

Pleurodictyum 25 Schuchertella $7,8,9,20,21 ; \mathrm{pl}$. newberryi, Orthostrophia strophomenoides

$7,11,27 ;$ pls. 3,8

Niagaran Formation, Tennessee ................ Nicholsonia

(Nicholsonia), Alleynia nolani, Kozlowskiellina

Nowakia acuaria

Nucleospira

ventricosa sp

10
38
2
7
6,
6,
10
5
12
17
8
.8
.2
6,
11
.3
18

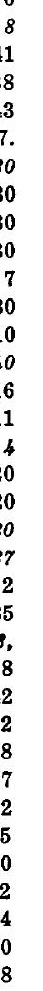


Page

oblata, Rhipidomella .................................... 26 occidentalis, Leptocoelia .... 7, 8, 10,11, s1; pl. 5

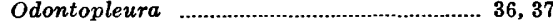
Odontopleuridae ........................................ s6 Orthidae ...................................................... 27

Orthis subcarinata Orthoceras …………………………........ 7,9,35 sp ………......................................... 10 (Orthonychia) sp. c, Platyceras ........ 7, s6; pl. 1 Orthostrophia strophomenoides ……………….......................... 7,27 newberryi ............ 7, 10, 11, 27; pls. 3, 8 parva .......................................... 27

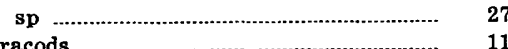

\section{$\mathbf{P}$}

Pachyporinae $\ldots \ldots \ldots \ldots \ldots \ldots \ldots \ldots \ldots \ldots \ldots \ldots \ldots . . .19,20$ pahranagatensis, Camarotoechia .. 15, 40; pl. 11 Pahranagat Range ........................................... 40 Palaeocyclus .............................................. 18

Papiliophyllum ............................................... 28 Parahealdia .............................................. convexoris ………................................ 11

Parastrophinidae …………………………..... 29

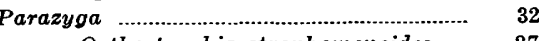
parva, Orthostrophia strophomenoides .... 27 pauciplicata, Howellella 14, 16, 33, 41, 42; pl. 12 perlamellosus, Spirifer ................................ 32

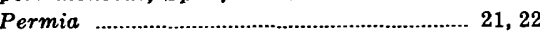
perplexum, Barrandeophyllum ..................... 22

Petes Canyon 8 Petrozium ……………………………………..... 38 Phacopidae …………………………….... 36, s7

Phacops ….... s7 birdsongensis ……………………......... 37 eanadensis ............................ 9, 10, 37; pl. 2 gaspensis …….................................... 37 logani ……............................... $s 7$

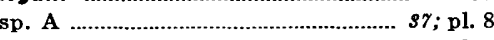
sp. B …………............... 9, 10, s7; pl. 2 sp ……................................ 7, 8, 9, 10 Pholadophyllum ……………………………........ Pholidophylum …………............................. 37

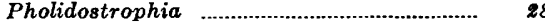
sp. $R$.............................. 7, 10, 28; pl. 3 pinyonensis, Spirifer ................................... 36 planicostatus, Costispirifer ........................ 34 arenosus ……............................. 34 Spirifer arenosus ……............................ 34 Platyceras ……………………………..... 35, s6 sp. a ….............................. $7,10,36 ;$ pl. 1 sp. b ……………............ 7, 10, 36; pl. 1 (Orthonychia) sp. c ............... 7, 10, s6; pl. 1

Platyceratidae Plethorhyncha ……………………………...... 29 altera ………......................................... 30 andersoni ..................... 7, 8, 10, 29, 30; pl. 6 barrandi ............................................. 30

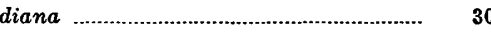
salinensis …………………………....... 30 speciosum welleri ……................................. 30

Pleurodictyum ……....... 8, 9, 11, 12, 19, 20,21, 35 dunbari ......................... 7, 10,21, 20; pl. 1 lenticulare ............................................. 19, 20

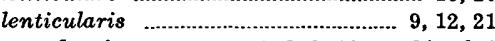
nevadensis ............... 7, 8,9,10, 20, 21; pl. 1 (Pleurodictyum) ............................... 20 problematicum ………………….............. 20 (Procteria) ………………….................. 20 stylopora ............................................... 20 tennesseensis ............................................ 20 trifoliatum …………………............... 20, 21 sp ……......................................... 8, 9, 10

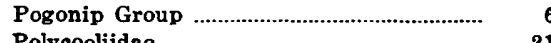
Polycoeliidae primaevus, Spirifer

Page

prinstana, Hindella

problematicum, Pleurodictyum

(Procteria) Pleurodictyum .......................... 20

Proetus sp ................................................ 8, 8,

Protathyris .......

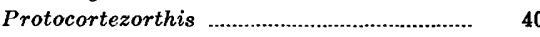

pseudodianthus, Entelophyllum ................ 38

punctulifera, Strophonella ......... 8, 10, 28; pl. 3 $\begin{array}{ll}\text { Purpose and scope of investigation .......... } & 2 \\ \text { pycnostylids }\end{array}$

Pycnostylus

sp ……….......................................... pl. 11

\section{$\mathbf{R}$}

Rabbit Hill ……………………………...... 6, 36 Rabbit Hill Limestone..................... 2, 5, 18, 42 age and correlation of .................... 3, 10 areal distribution and stratigraphy of 5 type area

conularids of

fossils of 35 $3,4,6,7,8,19,42$ relation to Lone Mountain Dolomite. $\quad 3,17$ tentaculitids of trilobites of

raricosta, Delthyris

11

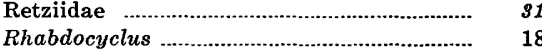

Rhipidomella .............................................. 25,26

henryhousensis ................................... 26

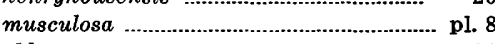

oblata .................................................. 26

rossi .............................. $7,10,25,26$; pl. 4

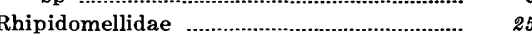

Rhipidomelloides ................................. 25, 26

rhomboidalis, Leptaena ................................... 28

robertsensis, Meristella ................................. 30

Roberts Mountains ……...................... 1, 3, 33, 40

Formation …….................. 2, 7, 10, 13, 32

Limestone ………….............. $3,4,5,12,18$

Rockhouse Shale, Tennessee ....................... 20, 21

Romano fault .......................................... 15 rossi, Rhipidomella …………-.......... 7, 25, 26; pl. 4 rugosa, Xylodes ....................................... 38

rugose corals …...... 2, 8, 11, 12,13,15,16,17, 18

\section{S}

Saccarchites sp ........................................... 11

salinensis, Plethorhyncha ............................

Salopina ....................................................... 40

crassiformis ......................................... 40 sp. $f$...................................... 16, $40 ; 11$ sp ...................................................... 40

Sandpile Dolomite, British Columbia, Canada .................................... 41

Schellwienella ............................................. 29 Schuchertella ................................. 7, 8, 10, 29 haraganensis ................. 7, 8,9, 10, 29; pl. 3 nevadensis ............................................ 29 sp …................................ 9, 29; pls. 3,8

Schuchertellidae

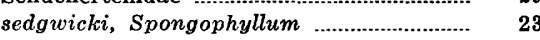

Selected bibliography

Sevy Dolomite

siluriensis, Cyatha

Simpson Park Range...................... 21, 23

$36,37,42$

Siphonophrentis ......................................... 28

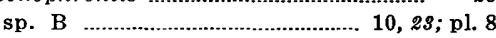
smithi, Howellella ........... 15, 16, 33, 41, 42; pl. 12 speciosum, Plethorhyncha ......................... 29 Spiniferina ........................................................
Page

Spinulosa .................................................. 11

Spirifer arenosus planicostatus .................

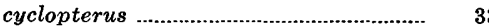

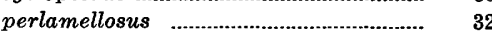

pinyonensis ............................................... 36

primaevus ............................................. 34

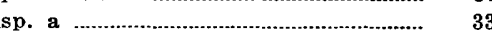

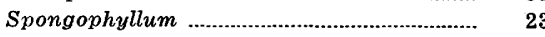

cyathophylloides ….............................23, 24

sedgwicki ................................................ 23

stevensi, Australophyllum .......... 11, 24, 25; pl. 9

Stortophyllum ........................................... 37

strawi, Kozlowskiella ................................... Kozlowskiellina ............................................

Streptelasmatidae …................................... 28

Striatopora …..............................6, 8, 10, 19, 20 flexuosa ................................................. 20 gwenensis ......................... 6, 8, 10, 20; pl. 1 sp ...................................................... 20

Strombodes .................................................. 38

Stropheodonta sp ............................ 7, 10; pl. 3

Stropheodontidae .................................... 27

strophomenoides newberryi, Orthostrophia _... 7, 11, 27; pls. 3, 8 Orthostrophia ....................................... 7, 27 parva, Orthostrophia ............................ 27 Strophonella .............................................. 8, 28

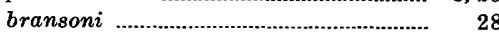
punctulifera ............................ 8, 10, 28; pl. 3 sp ....................................................... 10

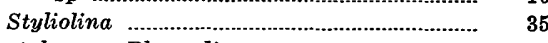
stylopora, Pleurodictyum ........................... 20 subcarinata antelopensis, Levenea .. 7, 8, 10, 11 ,

Levenea 26 ; pl. 4 Orthis

Sulphur Spring Range 2, 10, 15, 28, 29, 36, 42, 43 Sunday Canyon Formation, Vaughn Gulch Limestone, Mazourka

Canyon, Inyo Mountains, Calif

$11,12,24$

Syringaxon foerstei ….......... $7,8,9,10,11,22,23 ; \mathrm{pl} .2$ siluriensis ....................................... 21, 23

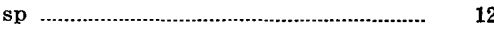

Syringopora Syringoporinae ............................................. 19 Systematic and descriptive paleontology .. 18

Tabulata tennesseensis, Atrypa ..................................... 41 Leptostrophia becki ......... 7, 8, 27; pls. 3, 8 Pleurodictyum …................................. 20 tentaculitids ............................... 8, 9, 10, 19, 35 Thamnopora sp ..................................... 14, 15, 16 Thlipsura furca ............................................ 11 sp ......................................................... 11 Toquima Range .................................. 2, 21, 42

Torquay Formation, England ................... 23 Trematospira ......................................... 31,40 cooperi ................................................ 32 deweyi .................................................... 32 equistriata .............................................. 31, 32 mcbridei ............................ 7, 10, 31, 32; pl. 6 multistriata ........................................... 32

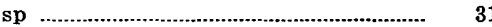
Tricornina sp ............................................. 11 trifoliatum, Pleurodictyum ..............................20, 21 trilobites .................................... 8, 11, 19, 35, 36

Tryplasma …............................................... 18, 87 aequabile ............................................ 37 sp. f ................................................. $s 8 ;$ pl. 11

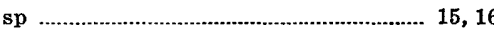
Tryplasmatidae ..........................................

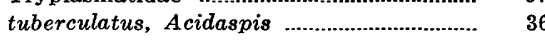
Leonaspis .............................. 7, 8, 9, 11, 36 Tubilibairdia $\mathrm{sp}$......................................... 11 Tuscarora Mountains ..................... 2, 9, 11, 25, 42 
INDEX

\begin{tabular}{|c|c|c|}
\hline & Page & Page \\
\hline $\mathrm{U}$ & & Velibeyrichia sp \\
\hline & & ventricosa, Leptaena \\
\hline 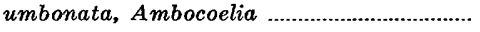 & 30 & Nucleospira \\
\hline Hindella & 41 & verneuili, Anastrophia .............. 10, 11, 29; pl. 5 \\
\hline 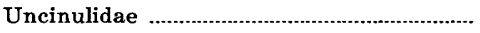 & 29 & Verticillopora \\
\hline 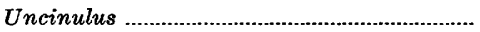 & 30 & \\
\hline 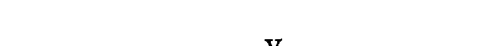 & & $\mathrm{W}$ \\
\hline variabilis, Glassia & 41 & $\begin{array}{l}\text { Walti Ranch, Walti Hot Springs } \\
\text { quadrangle }\end{array}$ \\
\hline 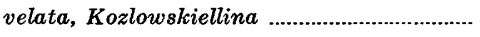 & 33 & - \\
\hline
\end{tabular}

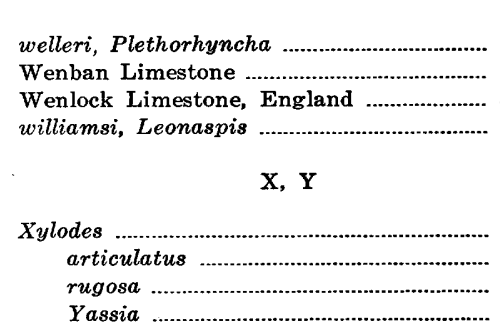

welleri, Plethorhyncha

30

9,11 32,38 36

velata, Kozlowskiellina 


\section{PLATES $1-12$}

[Contact photographs of the plates in this report are available, at cost, from the U.S

Geological Survey Photographic Library, Federal Center, Denver, Colorado 80225] 


\section{PLATE 1}

Figures 1, 3-6. Striatopora cf. S. gwenensis Amsden.

1. Lateral view $(\times 11 / 2)$; USNM 159475.

3. Lateral view $(\times 2)$; USNM 159476 .

4. Transverse thin section $(\times 2)$; USNM 159514.

5, 6. Longitudinal thin sections $(\times 2)$; USNM 159515, 159516.

Lower Devonian, Rabbit Hill Limestone; Rabbit Hall, Copenhagen Canyon, Nev. Locality M409.

2. Digitate favositid sp. a.

Lateral view ( $\times 1 \frac{11}{2}$ ); USNM 159513. Locality M409. (See figs. 1, 3-6.)

7-12. Pleurodictyum nevadensis $\mathrm{n}$. sp.

7, 8. Calice and lateral views of holotype $\left(\times 1 \frac{1}{2}\right)$; USNM 159517.

9. Lateral view of broken paratype $(\times 3)$; USNM 159518, showing pore distribution.

10. Interior view of wall $(\times 2)$; USNM 159519, showing pore pattern.

Locality M409. (See figs. 1, 3-6.)

11. Calice view $\left(\times 1 \frac{1}{2}\right)$; USNM 159520. Upper part of Rabbit Hill Limestone, Dobbin Summit, Monitor Range, Nev. Locality M1309.

12. Calice view $(\times 1)$; USNM 159521. Lower Devonian, Rabbit Hill Limestone; Horse Canyon, Cortez Mountains, Nev. Locality M1083.

tains, Nev. Locality M1083.

13-15. Pleurodictyum dunbari n. sp.

13. Lateral exterior of holotype $(\times 11 / 2)$; USNM 159522.

14. Calice view of holotype $(\times 21 / 2)$; USNM 159522.

15. Calice view of paratype $\left(\times 2 \frac{1}{2}\right)$; USNM 159523 .

Lower Devonian, Rabbit Hill Limestone; Rabbit Hill, Copenhagen Canyon, Nev. Locality M409.

16-19. Favosites cf. F. helderbergiae Hall.

16. Surface of massive colony $(\times 1)$.

17. Longitudinal thin section $(\times 2)$.

18. Transverse thin section $(\times 2)$.

19. Longitudinal thin section $(\times 2)$.

Lower Devonian, Rabbit Hill Limestone; Rabbit Hill, Copenhagen Canyon, Nev. Locality M409.

20, 21. Platyceras sp. a.

Umbilical and aperture views (× 1); USNM 159524. Lower Devonian, Rabbit Hill Limestone; Rabbit Hill, Copenhagen Canyon, Nev. Locality M409.

22, 23. Platyceras sp. b.

Lateral and aperture views ( $\times 1 \frac{1}{2}$ ) ; USNM 159525. Locality M409. (See figs. 20, 21.)

24. Platyceras (Orthonychia) sp. c

Elongate surface of body whorl ( $\times 1 \frac{1}{2}$ ) ; USNM 159526. Locality M409. (See figs. 20, 21.) 
GEOLOGICAL SURVEY
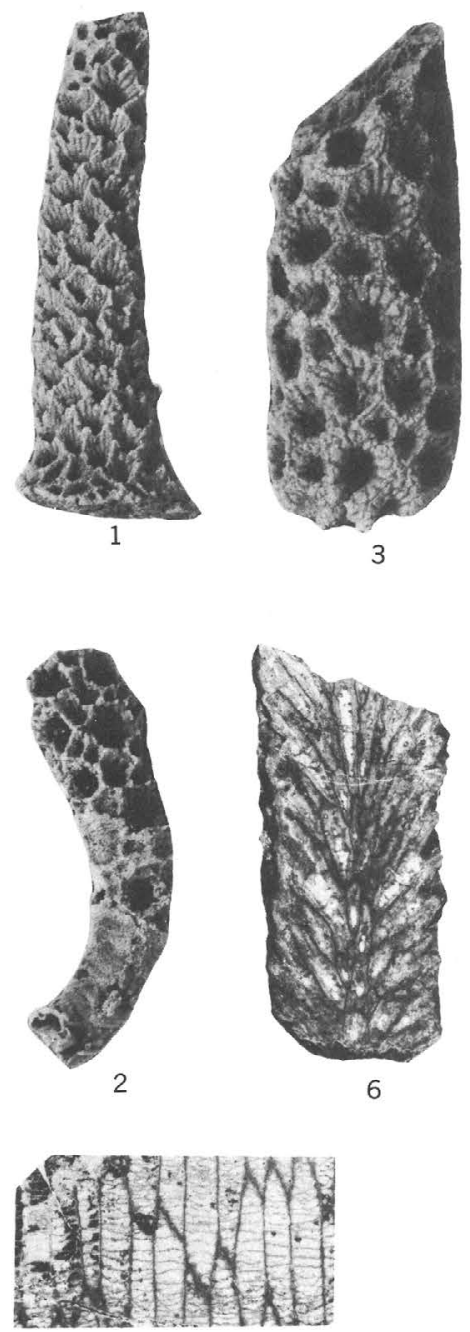

17

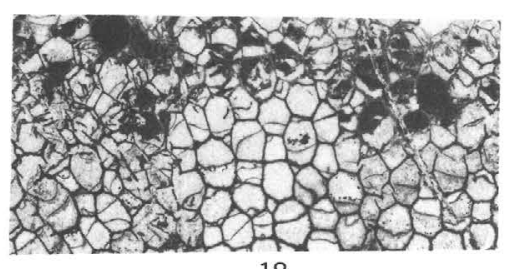

18

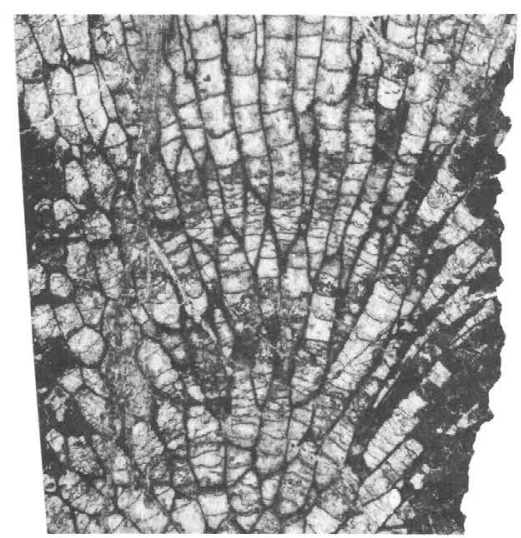

19
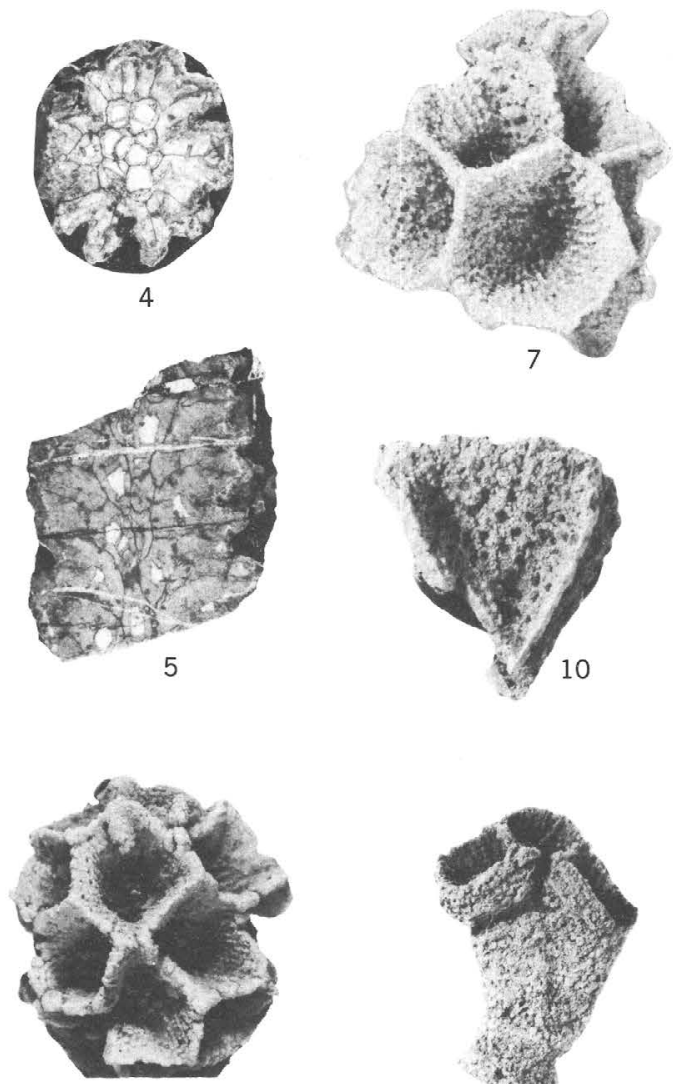

11

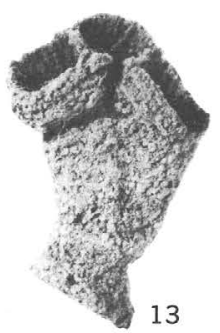

PROFESSIONAL PAPER 808 PLATE 1
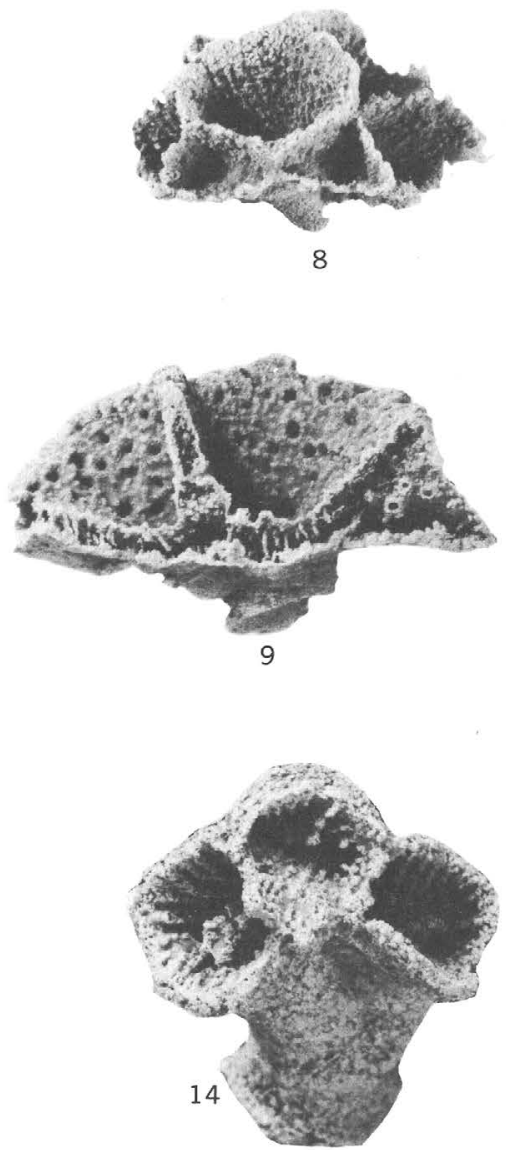
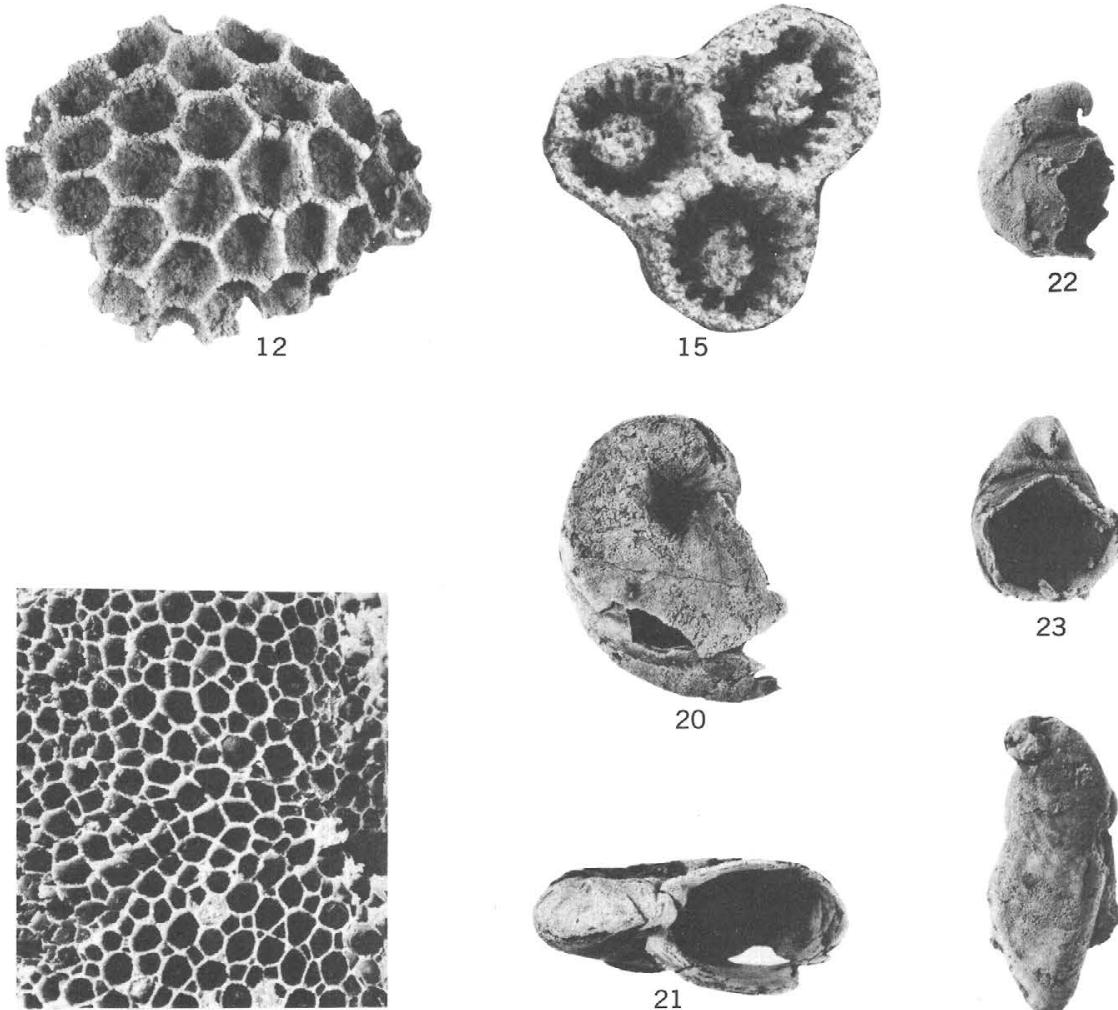

16
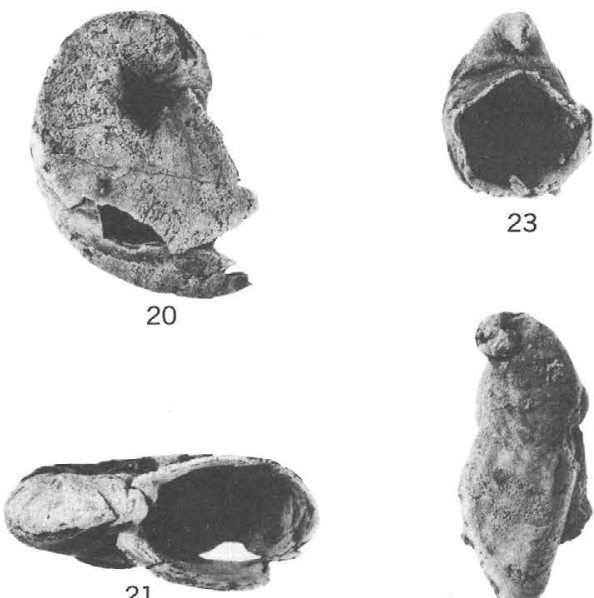

21

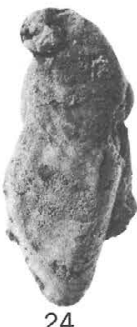

24 


\section{PLATE 2}

FIGURES 1-10. Syringaxon foerstei n. sp.

1. Oblique calice view of holotype $\left(\times 1 \frac{1}{2}\right.$ ); USNM 159243. Lower Devonian, Rabbit Hill Limestone; Rabbit Hill, Copenhagen Canyon, Nev. Locality M409.

2, 3. Lateral view $\left(\times 1 \frac{1}{2}\right)$ and calice view $(\times 1)$ of paratype USNM 159245. Locality M409. (See fig. 1.)

4. Lateral view of paratype ( $\times 2$ ); USNM 159527. Locality M409. (See fig. 1.)

5. Transverse thin section $(\times 4)$; USNM 159248. Lower Devonian, Rabbit Hill Limestone; Coal Canyon, Simpson Park Range, Nev. Locality M1032.

6. Transverse thin section of paratype ( $\times$ 4); USNM 159246. Locality M409. (See fig. 1.)

7. Calice view $(\times 2)$; USNM 159528. Lower Devonian, Beacon Peak Dolomite Member of the Nevada Formation; southern Sulphur Spring Range, Nev. Locality M197.

8. Calice view of paratype $\left(\times 2 \frac{1}{2}\right.$ ); USNM 159244. Locality M409. (See fig. 1.)

9, 10. Longitudinal thin section of two paratypes ( $\times 4$ ); USNM 159529, 159247. Locality M409. (See fig. 1.) 11-13. (?) Phacops sp. B, cf. P. canadensis Stumm.

11. Dorsal surface of nearly complete specimen ( $\times 1$ ); USNM 159530.

12. Cephalon showing right genal spine $(\times 1)$; USNM 159531.

13. Latex impression of pygidium $(\times 1)$; USNM 159532. Rabbit Hill Limestone, Coal Canyon, Simpson

14. (?) Miraspis sp.

Forked occipital ring spine $(\times 2)$. Lower Devonian, Rabbit Hill Limestone; Rabbit Hill, Copenhagen Canyon, Nev. Locality M409.

15-17. Leonaspis cf. L. tuberculatus (Hall).

15, 17. Pygidium ( $\times$ 4); USNM 159533 and free cheek $(\times 4)$; USNM 159534. Locality M409. (See fig. 14.)

16. Free cheek $(\times 2)$; USNM 159535. Lower Devonian, Rabbit Hill Limestone; Dobbin Summit, Monitor Range, Nev. Locality M1311.

18-20. Conularia sp., cf. C. huntiana Hall.

18. Lateral view $(\times 2)$; USNM 159536 .

19. Surface of large individual $(\times 2)$; USNM 159537.

20. Enlargement of part of fig. $19(\times 8)$.

Lower Devonian, Rabbit Hill Limestone; southeast of Walti Ranch, Simpson Park Range, Nev. Locality M1074. 

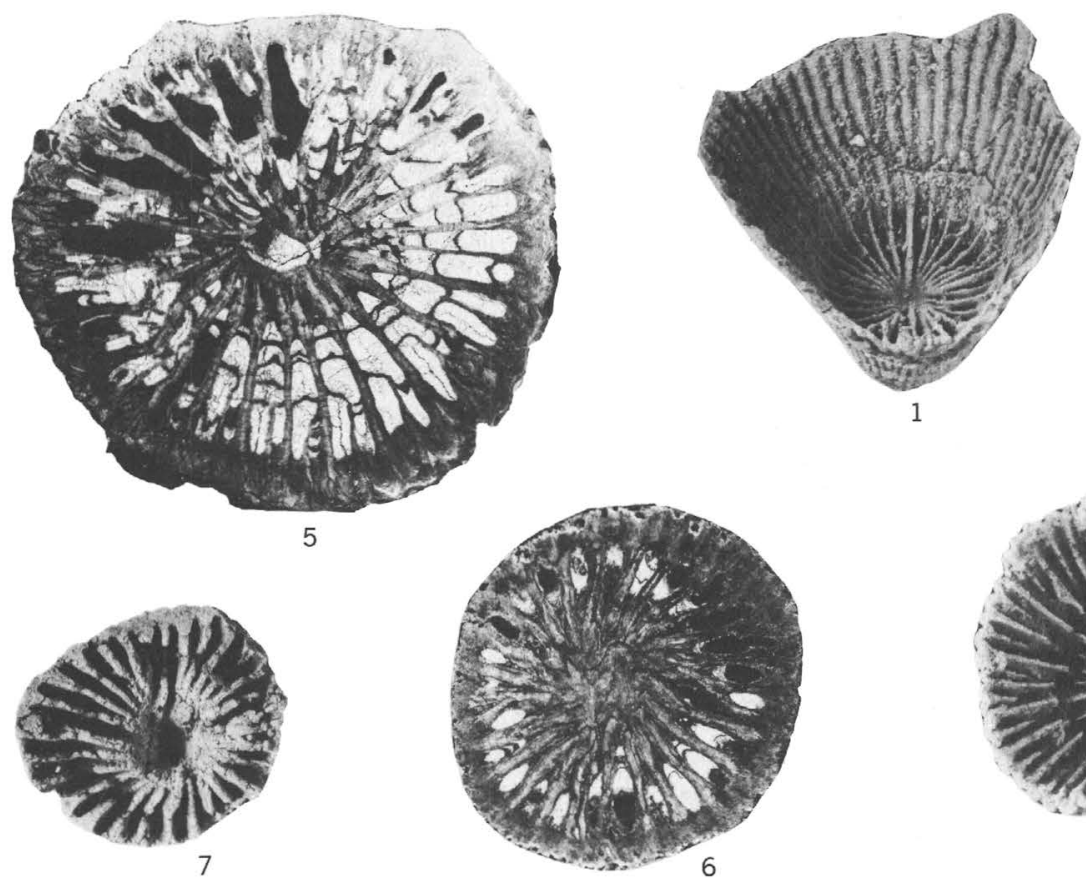

7

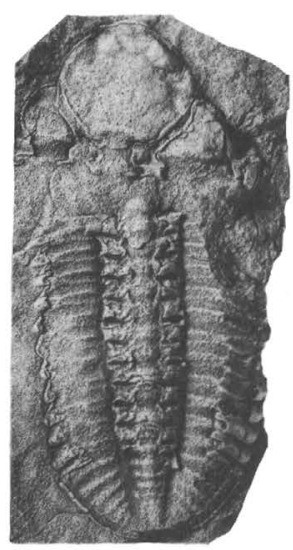

11

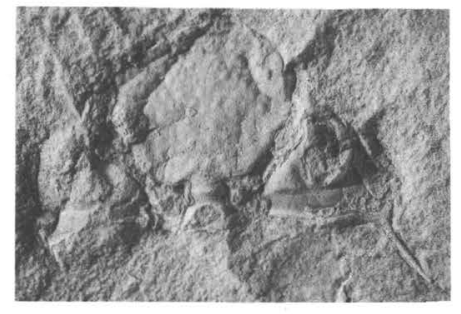

12

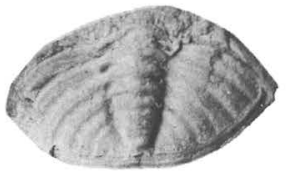

13

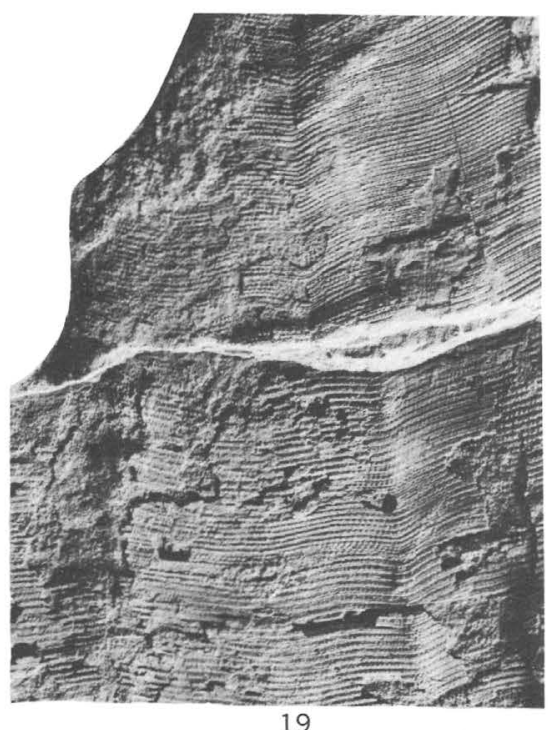

19
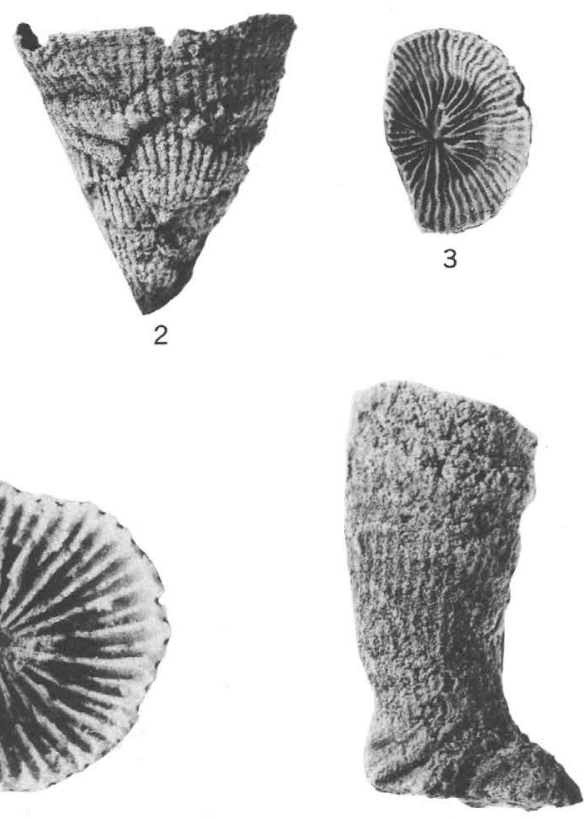

4

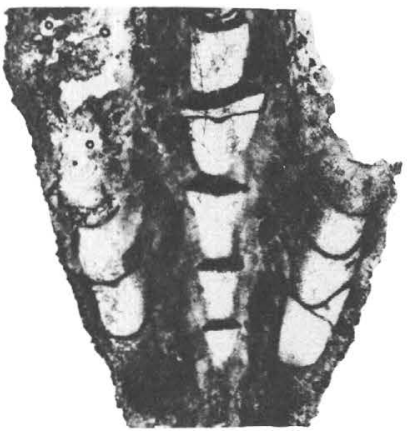

9

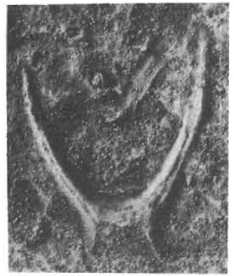

14

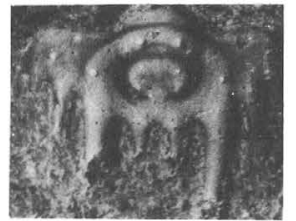

15
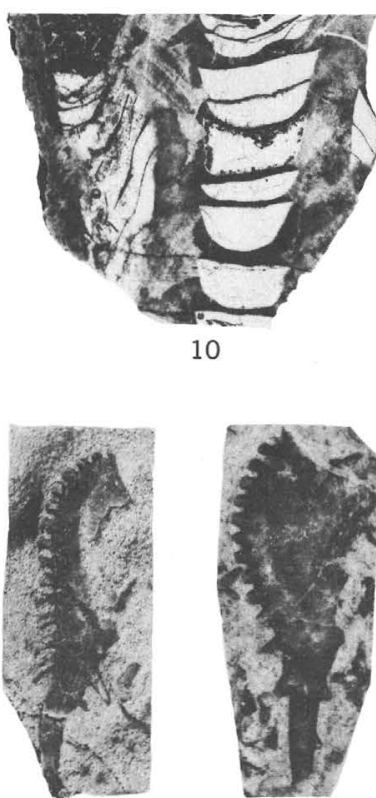

17

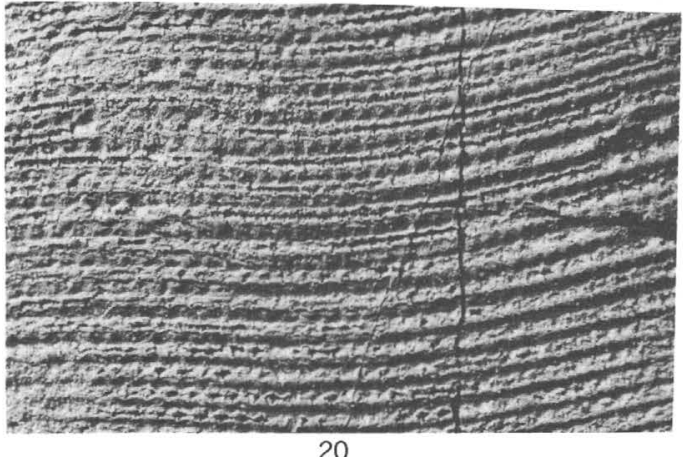

SYRINGAXON, (?) PHACOPS, (?) MIRASPIS, LEONASPIS, AND CONULARIA 


\section{PLATE 3}

FIGURES

1-3. Leptostrophia sp. cf. L. becki tennesseensis Dunbar.

1, 2. Exterior and interior of pedicle valve $(\times 2)$; USNM 159538.

3. Exterior of pedicle valve $(\times 2)$; USNM 159539 .

Lower Devonian, Rabbit Hill Limestone; Rabbit Hill, Copenhagen Canyon, Nev. Locality M409.

4, 5. Orthostrophia strophomenoides subsp. newberryi n. subsp.

Exterior and interior $(\times 2)$ of holotype; USNM 159540. Locality M409. (See figs. 1-3.)

6,7. (?) Pholidostrophia sp. R.

Exterior $(\times 1)$ and interior $(\times 2)$ of pedicle valve; USNM 159541. Locality M409. (See figs. 1-3.)

8, 9. Stropheodonta sp.

Exterior $(\times 1)$ and interior $\left(\times 1 \frac{1}{2}\right)$ of same pedicle valve. Locality M409. (See figs. 1-3.)

10, 11. Strophonella cf. S. punctulifera (Conrad).

10. Latex impression of probable pedicle valve $(\times 2)$.

11. Latex impression of brachial valve exterior $(x 1)$.

Lower Devonian, Beacon Peak Dolomite Member of the Nevada Formation; southern Sulphur Spring Range, Nev. Locality M197.

12-15. Schuchertella sp., cf. S. haraganensis Amsden.

12-14. Pedicle valve exterior, interior and hinge views ( $\times 11 / 2)$; USNM 159542.

15. Pedicle valve exterior ( $\times$ 11/2); USNM 159543. Locality M409. (See figs. 1-3.)

16, 17, 19. Leptaena fremonti $\mathrm{n}$. sp.

16, 17. Pedicle valve exterior and interior $(\times 1)$, holotype; USNM 159544

19. Pedicle valve interior ( $\times 1$ ), paratype; USNM 159545. Locality M409. (See figs. 1-3.)

18. Leptaena sp., cf. L. fremonti $\mathrm{n}$. sp.

Pedicle valve exterior $\left(\times 1 \frac{1}{2}\right)$; USNM 159546. Lower Devonian, Beacon Peak Dolomite Member of the Nevada Formation; southern Sulphur Spring Range, Nev. Locality M197. 
GEOLOGICAL SURVEY
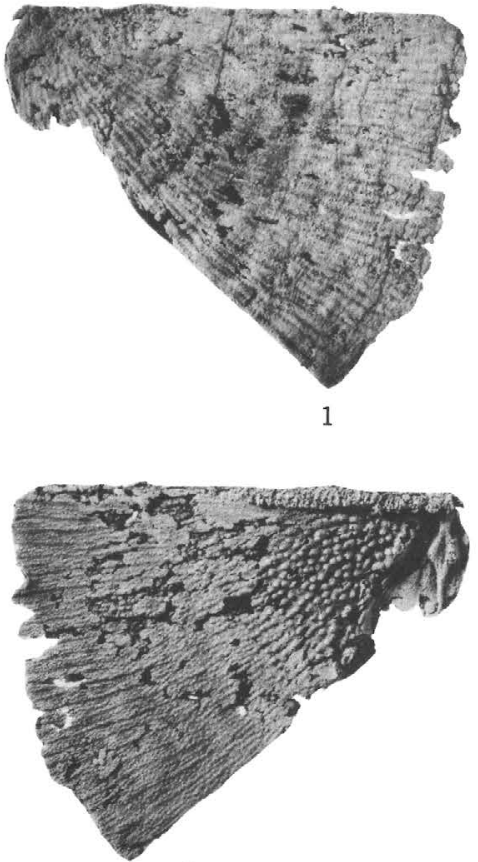

2
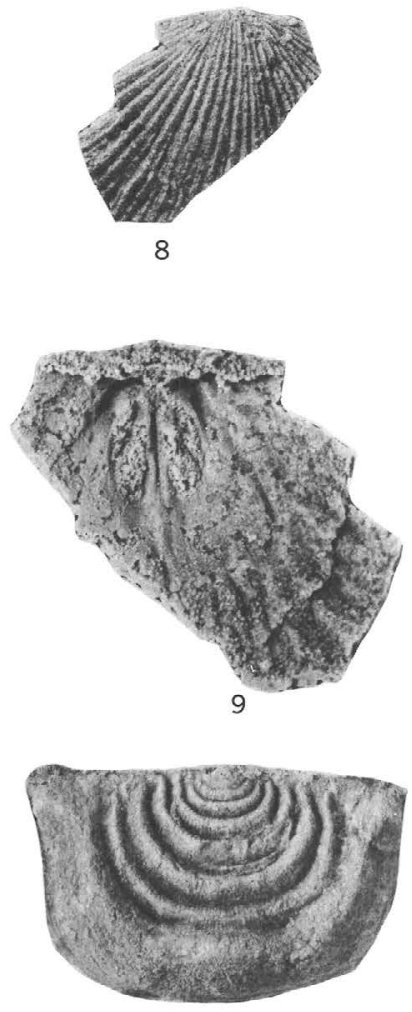

18

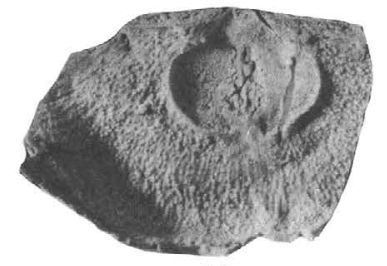

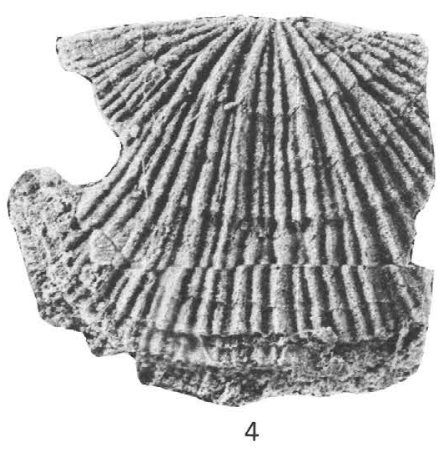
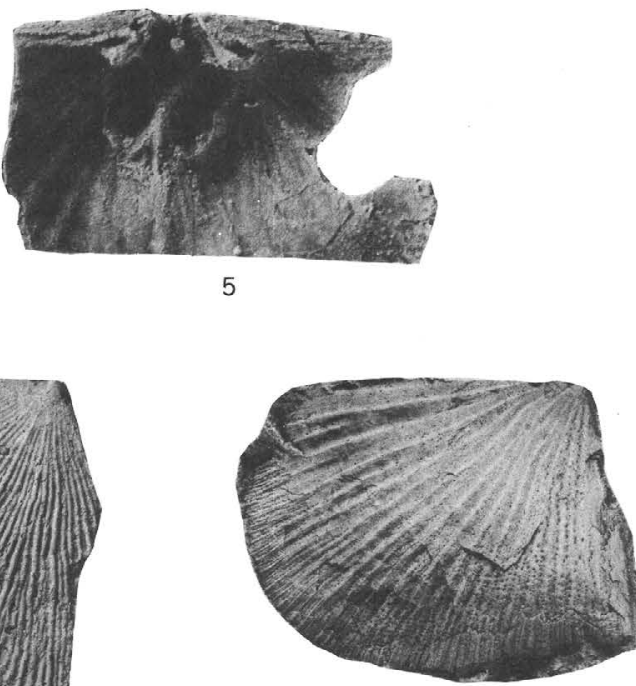

11

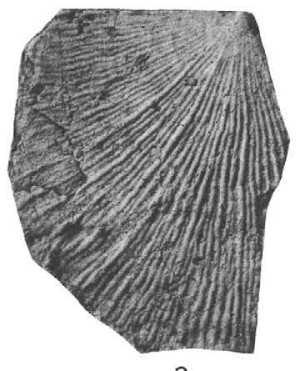

3
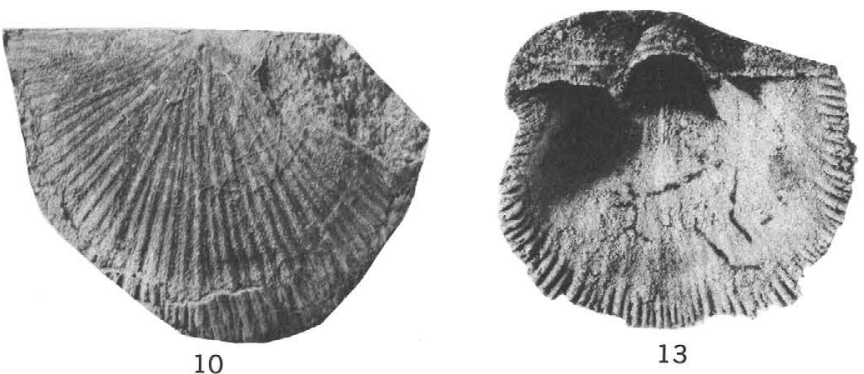

13
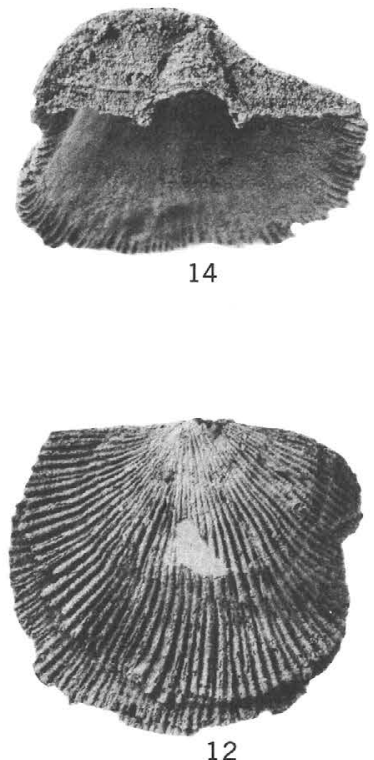

14

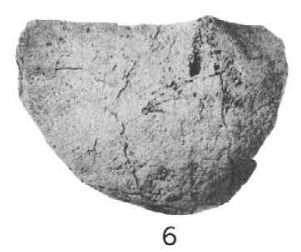

19
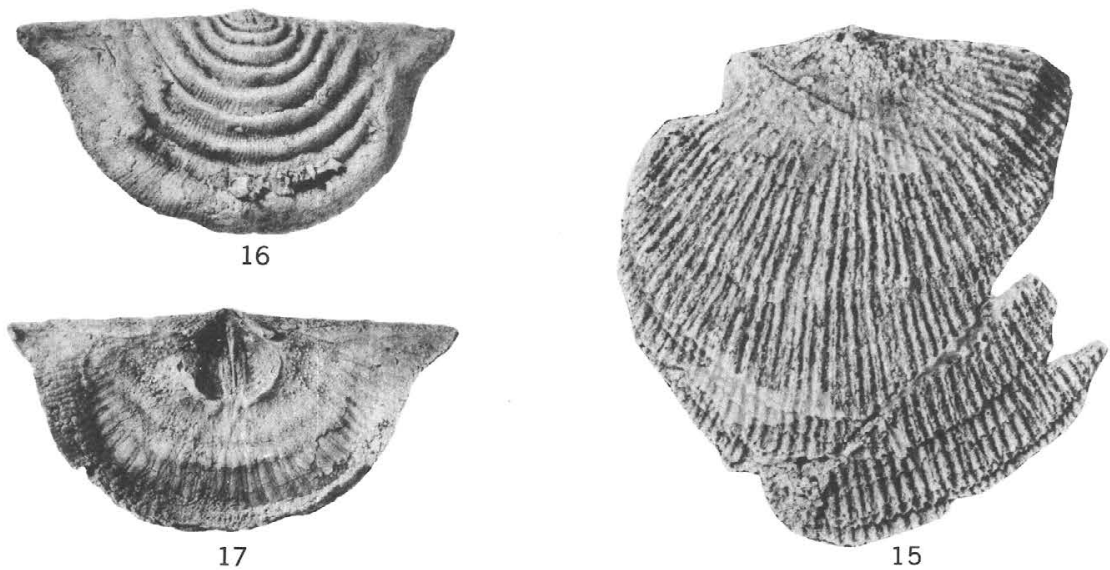

LEPTOSTROPHIA, ORTHOSTROPHIA, (?) PHOLIDOSTROPHIA, STROPHEODONTA,

STROPHONELLA, SCHUCHERTELLA, AND LEPTAENA 


\section{PLATE 4}

FiguRES 1-14. Levenea subcarinata subsp. antelopensis $\mathrm{n}$. subsp.

1-3. Exterior, interior, and umbonal views $(\times 2)$, holotype pedicle valve; USNM 159547.

4-6. Umbonal view $(\times 2)$, exterior and interior $\left(\times 1 \frac{1}{2}\right)$, paratype brachial valve; USNM 159548.

Lower Devonian, Rabbit Hill Limestone; Rabbit Hill, Copenhagen Canyon, Nev. Locality M409.

7. Brachial valve interior ( $\times 2$ ), paratype; USNM 159549. Lower Devonian, Beacon Peak Dolomite Member of the Nevada Formation, southern Sulphur Spring Range, Nev. Locality M186.

8. Umbonal view of articulated shell $\left(\times 1 \frac{1}{2}\right)$, paratype; USNM 159550. Locality M186. (See fig. 7.)

9. Dorsal interior ( $\times 2$ ), paratype; USNM 159551. Locality M409. (See figs. 1-6.)

10. Pedicle interior $(\times 2)$, paratype; USNM 159552. Locality M409. (See figs. 1-6.)

11, 12. Brachial valve exterior and interior $\left(\times 1 \frac{1}{2}\right)$, paratype; USNM 159553. Rabbit Hill Limestone, Dobbin Summit, Monitor Range, Nev. Locality M1309.

13, 14. Pedicle valve interior and exterior $\left(\times 1 \frac{1}{2}\right)$, paratype; USNM 159554. Lower Devonian, Beacon Peak Dolomite Member of the Nevada Formation, southern Sulphur Spring Range, Nev. Locality M1312.

15-24. Rhipidomella rossi $\mathrm{n}$. sp.

15-17. Dorsal valve exterior, lateral and umbonal views $(\times 2)$, paratype; USNM 159555.

18, 19. Dorsal valve exterior and interior ( $\times 2$ ), holotype; USNM 159556.

20. Dorsal valve interior ( $\left.\times 2 \frac{1}{2}\right)$, paratype; USNM 159557.

21. Ventral valve interior $\left(\times 2 \frac{1}{2}\right)$, paratype; USNM 159558.

22. Ventral valve interior $(\times 2)$, paratype; USNM 159559.

23. Ventral valve interior $\left(\times 2 \frac{1}{2}\right)$, paratype; USNM 159560 .

24. Dorsal valve interior $\left(\times 2 \frac{1}{2}\right)$, paratype; USNM 159561.

Lower Devonian, Rabbit Hill Limestone; Rabbit Hill, Copenhagen Canyon, Nev. Locality M409. 
GEOLOGICAL SURVEY
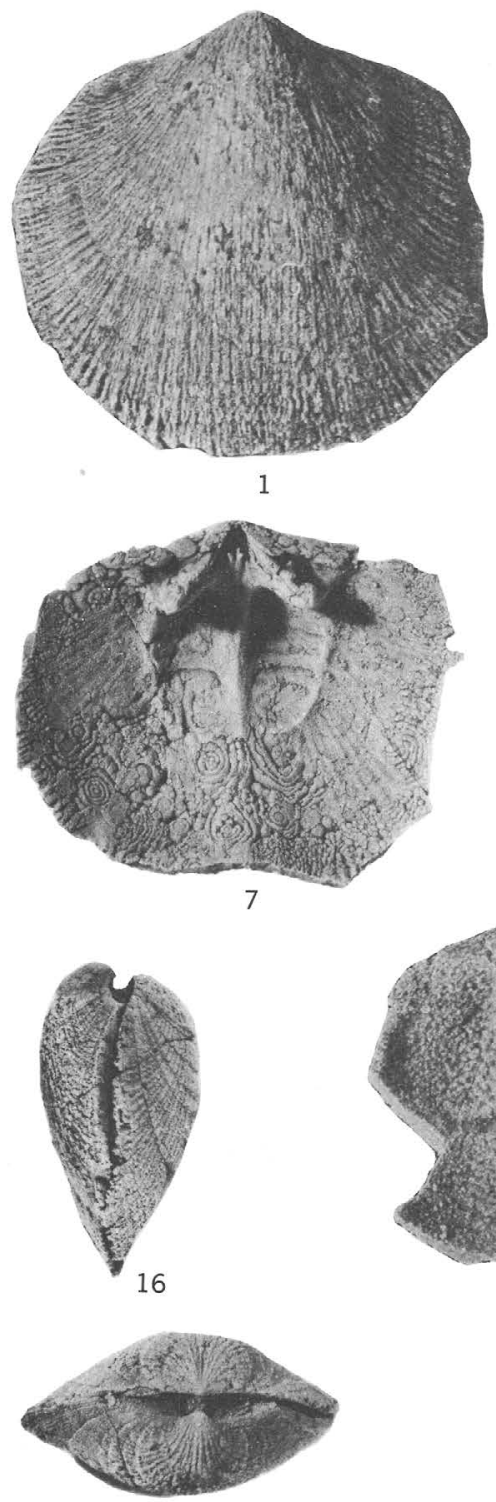

17
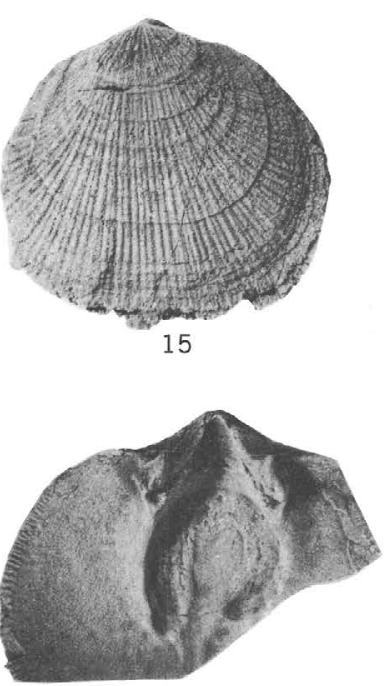

21
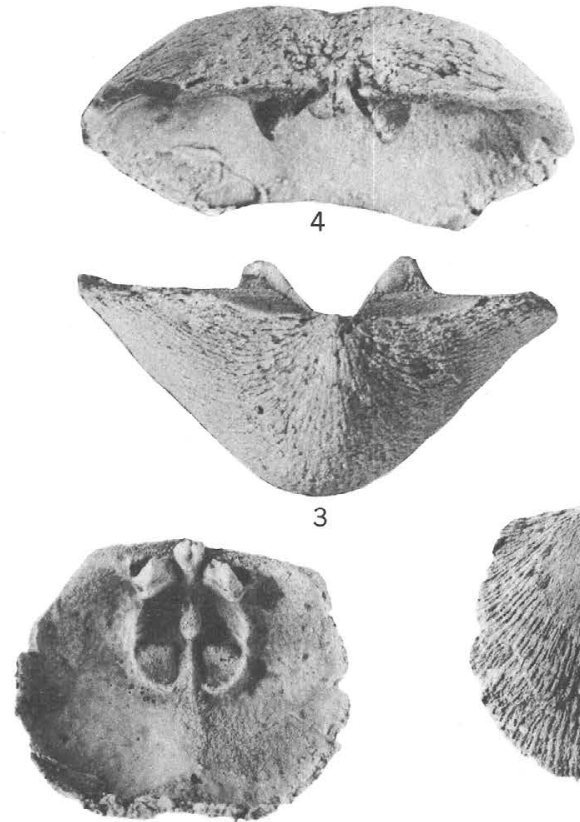

6

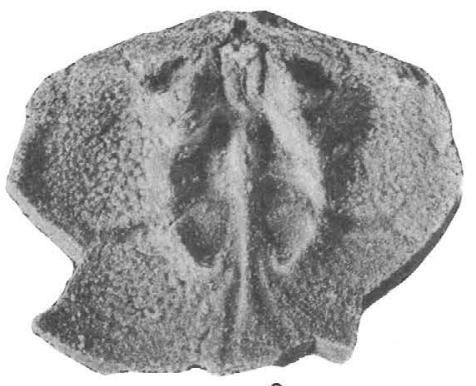

9

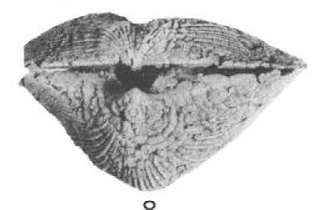

8
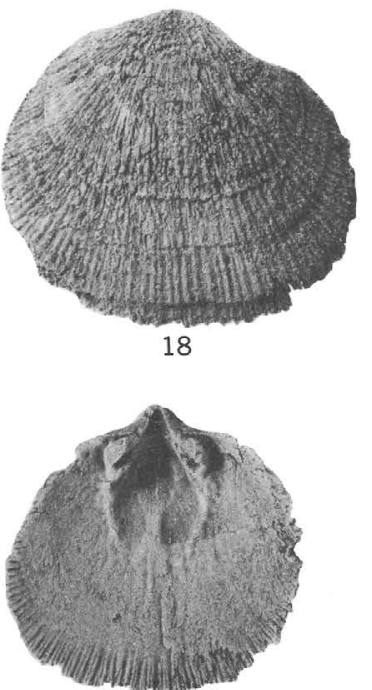

22

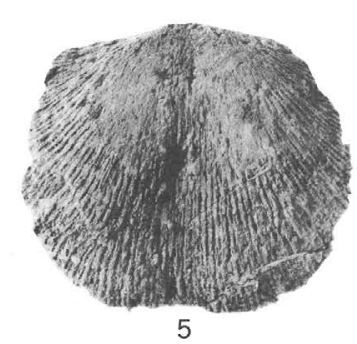

5
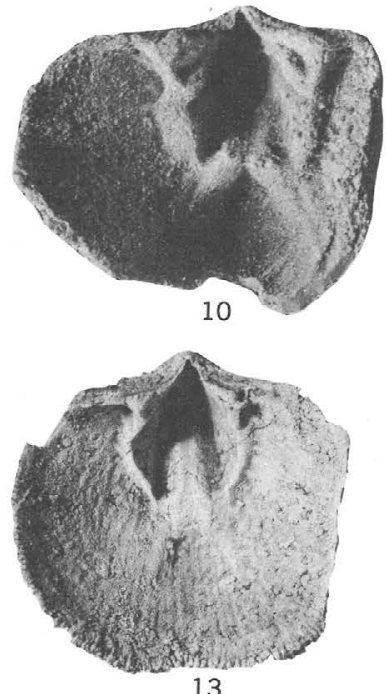

13
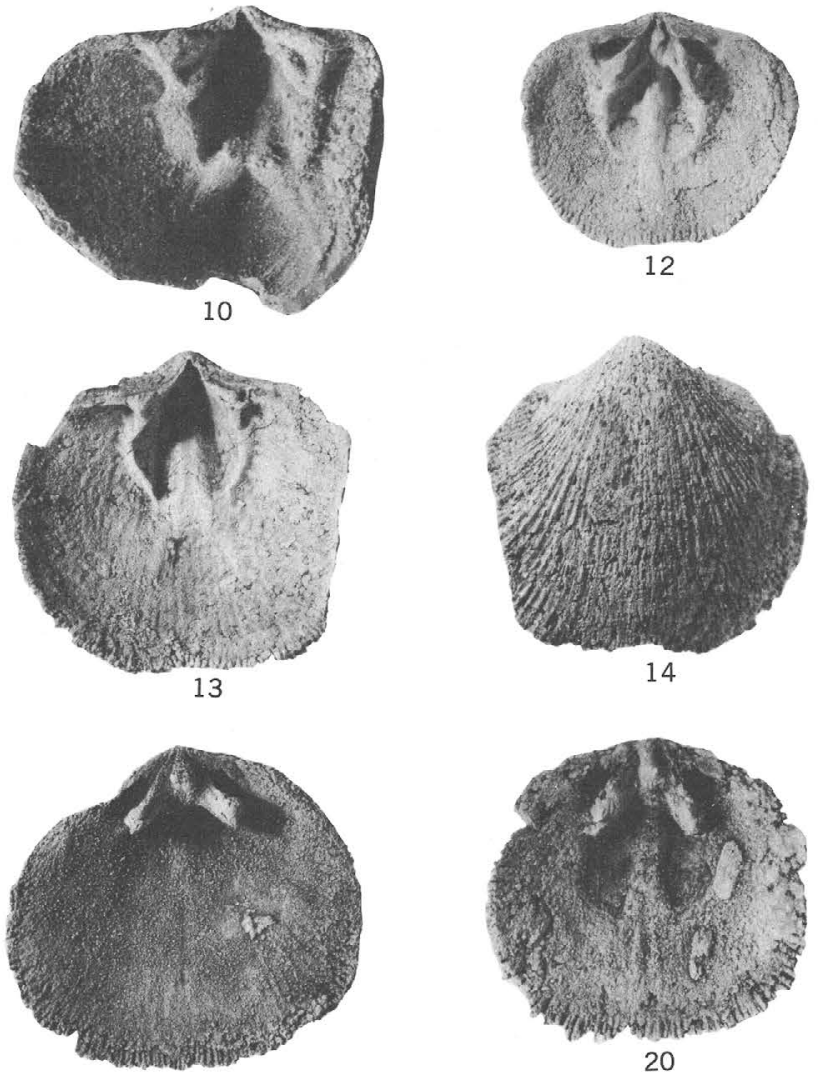

19

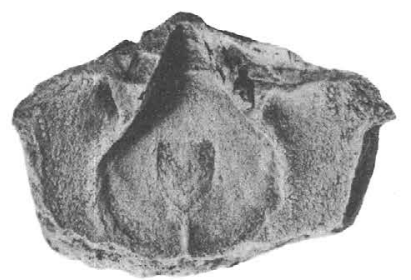

23
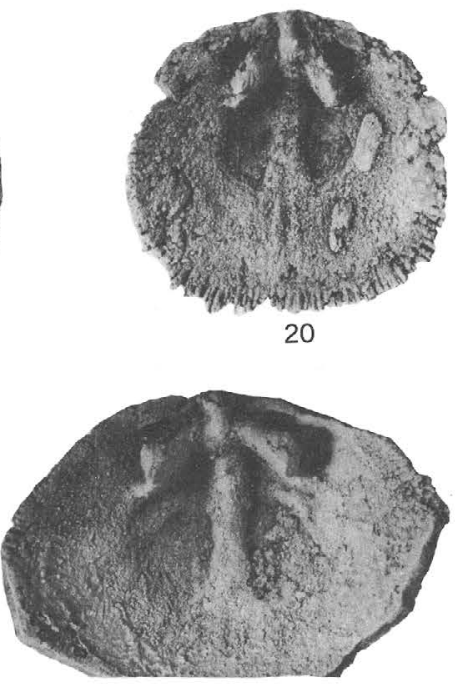

24 


\section{PLATE 5}

Figures 1-14. Leptocoelia occidentalis n. sp.

1, 2, 4. Pedicle valve, brachial valve, and lateral exterior views $(\times 2)$, holotype; USNM 159562.

3 , 5. Anterior $(\times 2)$ and umbonal $(\times 11 / 2)$ views, paratype; USNM 159563.

Lower Devonian, Rabbit Hill Limestone; Rabbit Hill, Copenhagen Canyon, Nev. Locality M409.

6, 7. Brachial valve and pedicle valve exterior $\left(\times 1 \frac{1}{2}\right.$ ), paratype; USNM 159564. Lower Devonian, Beacon Peak Dolomite Member of the Nevada Formation, southern Sulphur Spring Range, Nev. Locality M197.

8, 9. Brachial valve exterior $(\times 2)$ and interior $(\times 3)$, paratype; USNM 159565. Locality M409. (See figs. 1-5.)

10. Pedicle valve interior ( $\times$ 2), paratype; USNM 159566. Locality M409. (See figs. 1-5.)

11, 12. Pedicle valve interior of two paratypes ( $\times 2$ ); USNM 159567, 159568. Locality M409. (See figs. 1-5.)

13, 14. Brachial valve interior of two paratypes ( $\times$ 3); USNM 159569, 159568. Locality M409. (See figs. 1-5.) 15-19. Anastrophia cf. A. verneuili (Hall).

15, 18, 19. Pedicle valve exterior $\left(\times 1 \frac{1}{2}\right)$ and two views of interior of same individual; USNM 159571. Lower Devonian, Beacon Peak Dolomite Member of the Nevada Formation; southern Sulphur Spring Range, Nev. Locality M186.

16. Pedicle valve exterior ( $\times 1$ ); USNM 159572. Lower Devonian, Beacon Peak Dolomite Member of the Nevada Formation; southern Sulphur Spring Range, Nev. Locality M197.

17. Pedicle valve exterior ( $\times 1 \frac{1}{2}$ ); USNM 159573. Locality M197. (See fig. 16.) 
GEOLOGICAL SURVEY
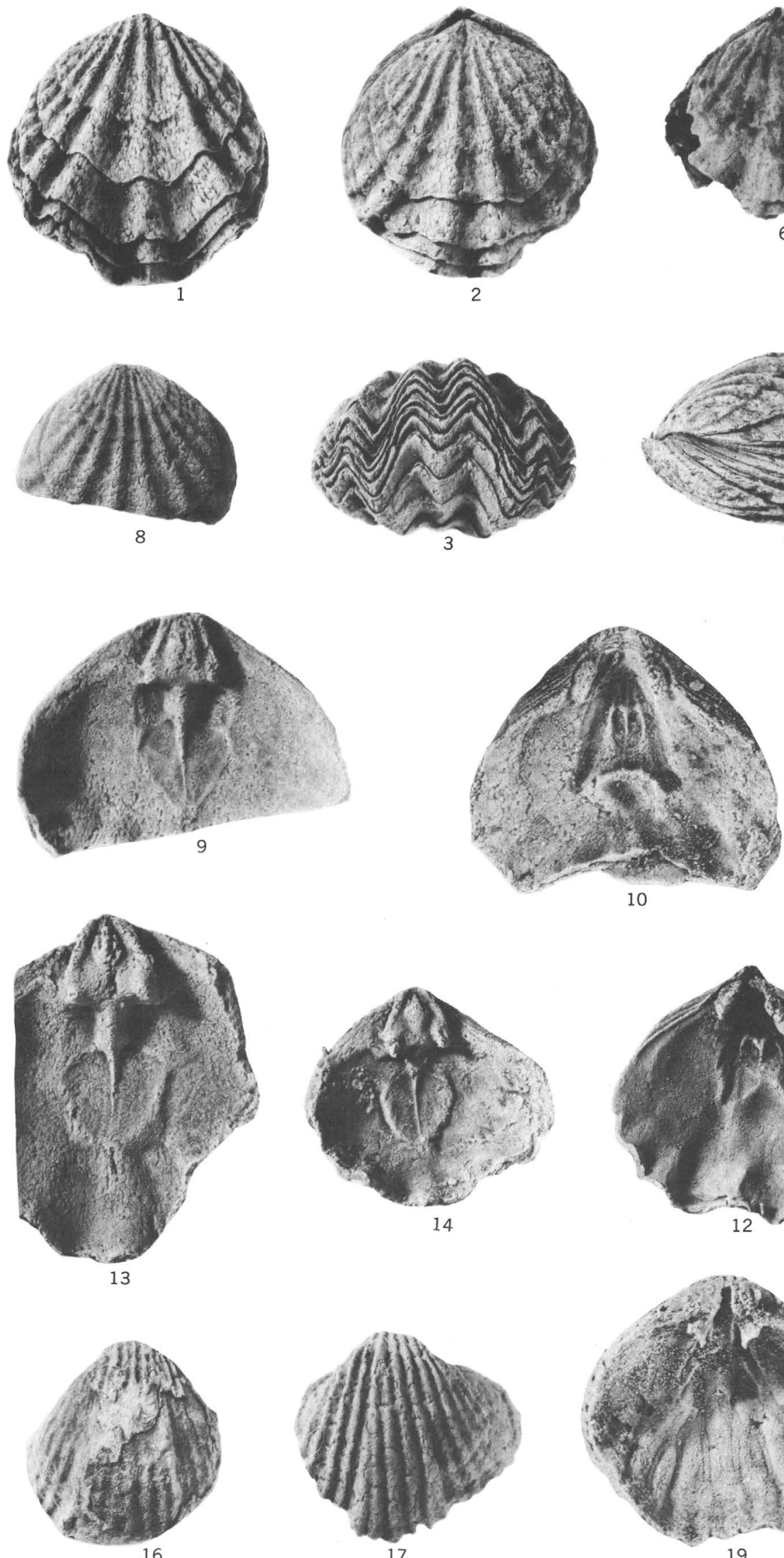

16
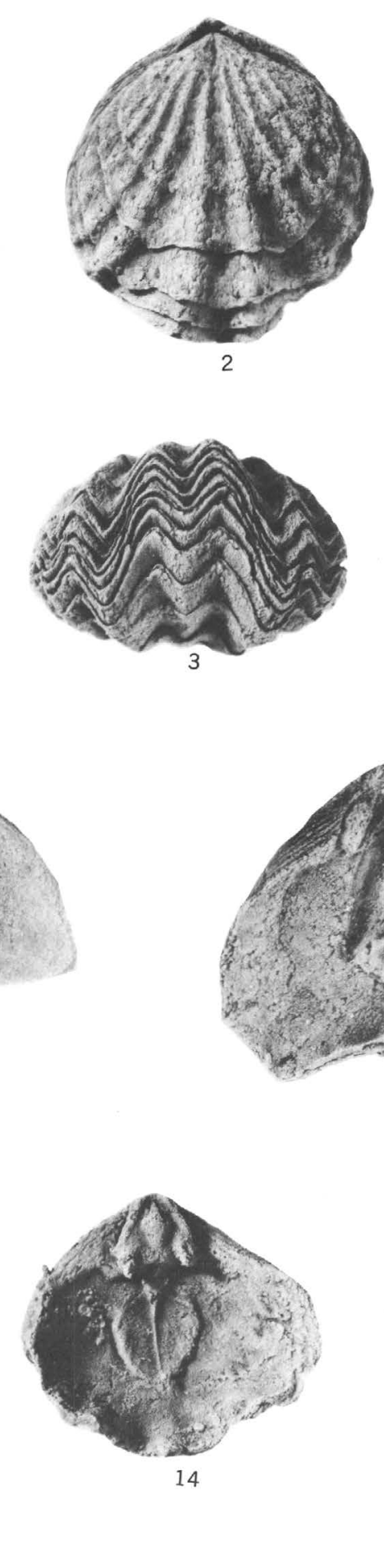

19
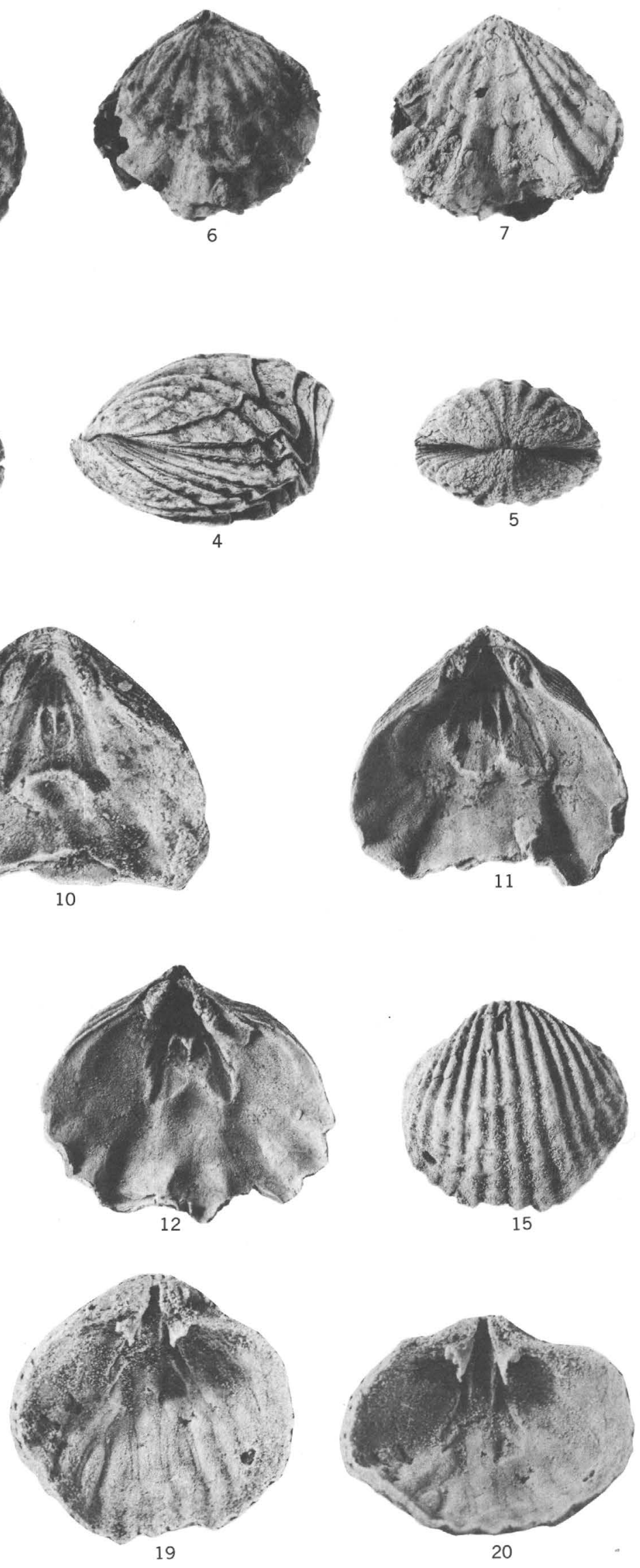

LEPTOCOELIA AND ANASTROPHIA 


\section{PLATE 6}

FIGURE. 1-7. Plethorhyncha andersoni n. sp.

1, 2. Brachial valve exterior and anterior view ( $\times 1$ ); holotype, USNM 159574.

3, 5. Pedicle valve exterior of two paratypes $(\times 1)$; USNM 159575, 159576.

4, 7. Brachial valve exterior $(\times 1)$ and interior $(\times 2)$; paratype, USNM 159577.

6. Pedicle valve interior $(\times 1)$; paratype, USNM 159578.

Lower Devonian, Rabbit Hill Limestone; Rabbit Hill, Copenhagen Canyon, Nev. Locality M409.

8-15. Trematospira mcbridei n. sp.

8, 10. Pedicle valve exterior $(\times 1)$ and interior $(\times 2)$; holotype, USNM 159579.

9. Pedicle valve exterior $(\times 11 / 2)$; paratype, USNM 159580.

11. Pedicle valve interior $(\times 2)$; paratype, USNM 159581.

12. Pedicle valve interior $(\times 2)$; paratype, USNM 159582.

13-15. Brachial valve interior of three paratypes $(\times 2)$; USNM 159583, 159584, 159585, showing details of the cardinal process.

Locality M409. (See figs. 1-7.)

16-24. Kozlowskiellina nolani $\mathrm{n}$. sp.

16. Brachial valve exterior ( $\left.\times 11 \frac{1}{2}\right)$; paratype, USNM 159586.

17. Brachial valve interior $\left(\times 1 \frac{1}{2}\right)$; paratype, USNM 159587.

18. Brachial valve interior $(\times 3)$; paratype, USNM 159588.

19. Pedicle valve exterior ( $\times 2$ ); holotype, USNM 159589.

20, 21. Pedicle valve interior of two paratypes $\left(\times 1 \frac{11}{2}\right)$; USNM 159590, 159591

Locality M409. (See figs. 1-7.)

22. Pedicle valve interior $\left(\times 1 \frac{1}{2}\right)$; paratype, USNM 159592. Rabbit Hill Limestone; Dobbin Summit, Monitor Range, Nev. Locality M1309.

23. Oblique posterior view $\left(\times 1 \frac{1}{2}\right.$ ). Locality M409. (See figs. 1-7.)

24. Pedicle valve interior ( $\times 2)$; holotype, USNM 159589. Locality M409. (See figs. 1-7.) 

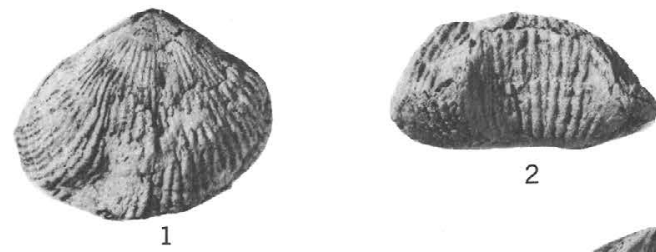

2
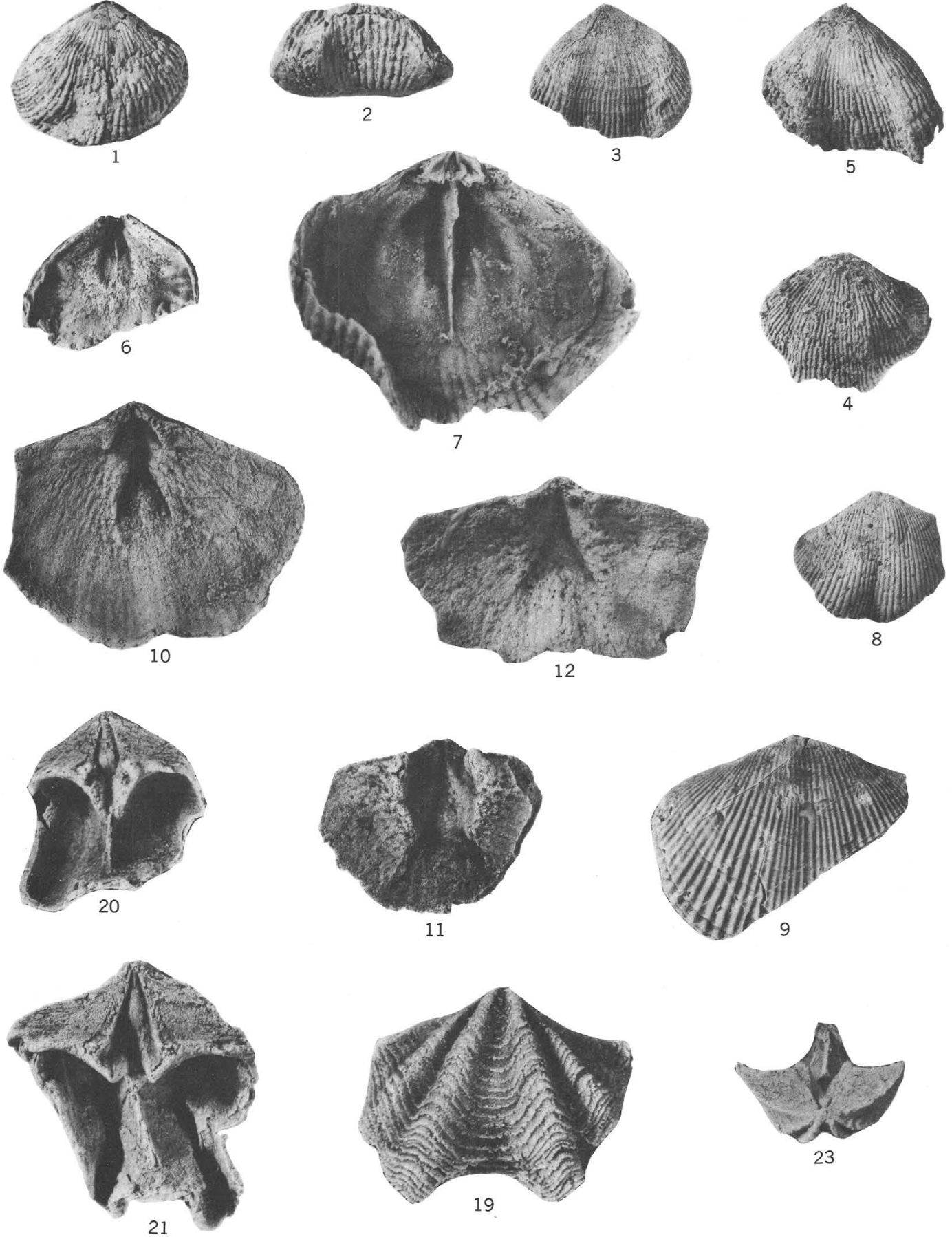

23

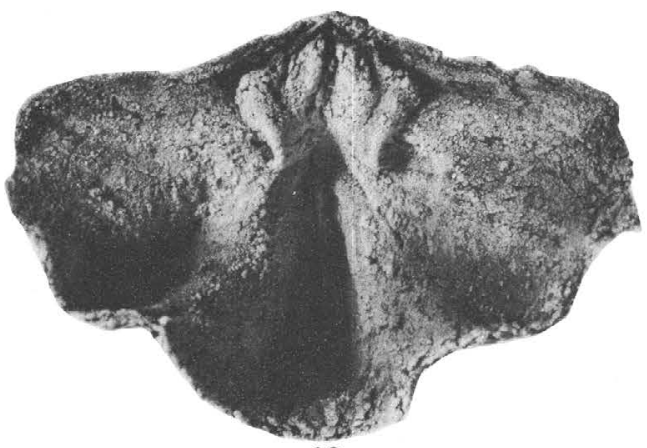

18
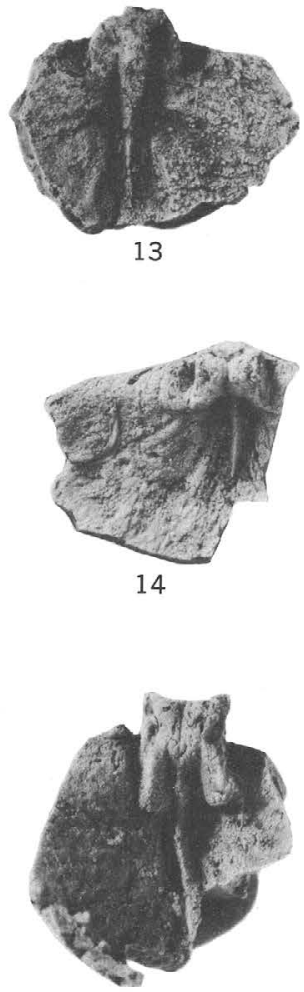

15

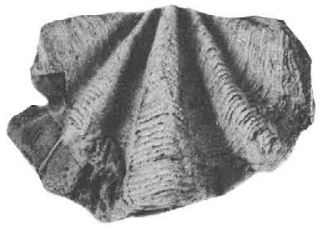

16
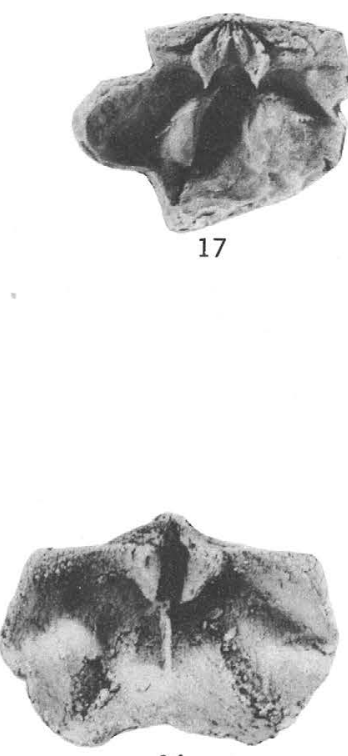

24

PLETHORHYNCHA, TREMATOSPIRA, AND KOZLOWSKIELLINA 


\section{PLATE 7}

Figures 1-7. Costispirifer arenosus subsp. dobbinensis n. subsp.

1, 4. Pedicle valve exterior $\left(\times 1 \frac{1}{2}\right)$ and posterior view $(\times 1)$; paratype, USNM 159593.

2, 3. Pedicle valve exterior $(\times 1)$ and interior $\left(\times 1 \frac{1}{2}\right)$; holotype, USNM 159594 .

5. Brachial valve exterior $(\times 1)$; paratype, USNM 159595.

6, 7. Pedicle valve exterior of two paratypes; USNM 159596, 159597.

Lower Devonian, Rabbit Hill Limestone; Dobbin Summit, Monitor Range, Nev. Locality M1309.

8. Acrospirifer sp.

Pedicle valve exterior ( $\times$ 2); USNM 159598. Locality M1309. (See figs. 1-7.)

9-12. Acrospirifer kleinhampli n. sp.

9, 10. Pedicle valve exterior and interior ( $\times 1 \frac{1}{2}$ ); holotype, USNM 159599.

11, 12. Pedicle valve exterior and interior $\left(\times 1 \frac{1}{2}\right)$; paratype, USNM 159600.

Locality M1309. (See figs. 1-7.)

13, 14. Acrospirifer sp. D.

Brachial valve exterior and interior ( $\times$ 11/2); USNM 159601. Locality M1309. (See figs. 1-7.)

15, 16. Acrospirifer cf. A. kleinhampli n. sp.

Pedicle valve exterior and interior ( $\times 11 / 2)$; USNM 159602. Lower Devonian, Beacon Peak Dolomite Mem-

ber of the Nevada Formation; southern Sulphur Spring Range, Nev. Locality M197.

17-22. Howellella cycloptera subsp. monitorensis n. subsp.

17. Brachial valve interior ( $\times 2$ ); paratype, USNM 159603.

18, 19. Pedicle valve interior and exterior $\left(\times 1 \frac{1}{2}\right)$; holotype, USNM 159604.

Lower Devonian, Rabbit Hill Limestone; Rabbit Hill, Copenhagen Canyon, Nev. Locality M409.

20-22. Pedicle valve, brachial valve, and anterior views $(\times 11 / 2)$; paratype, USNM 159605.

Lower Devonian, Rabbit Hill Limestone; Dobbin Summit, Monitor Range, Nev. Locality M1311.

23-27. Meristella martini n. sp.

23, 24. Pedicle valve exterior and interior $(\times 1)$; holotype, USNM 159606.

25, 26. Pedicle valve interior $\left(\times 1 \frac{1}{2}\right)$ and exterior $(\times 1)$; paratype, USNM 159607 .

27. Brachial valve interior $\left(\times 1 \frac{1}{2}\right)$; paratype, USNM 159608.

Locality M409. (See figs. 17-19.)

28-31. Ambocoelia sp. a

28. Pedicle valve exterior $(\times 3)$; USNM 159609.

29-31. Three pedicle valve interiors ( $\times 3$ ); USNM 159610, 159611, 159612.

Locality M409. (See figs. 17-19.) 

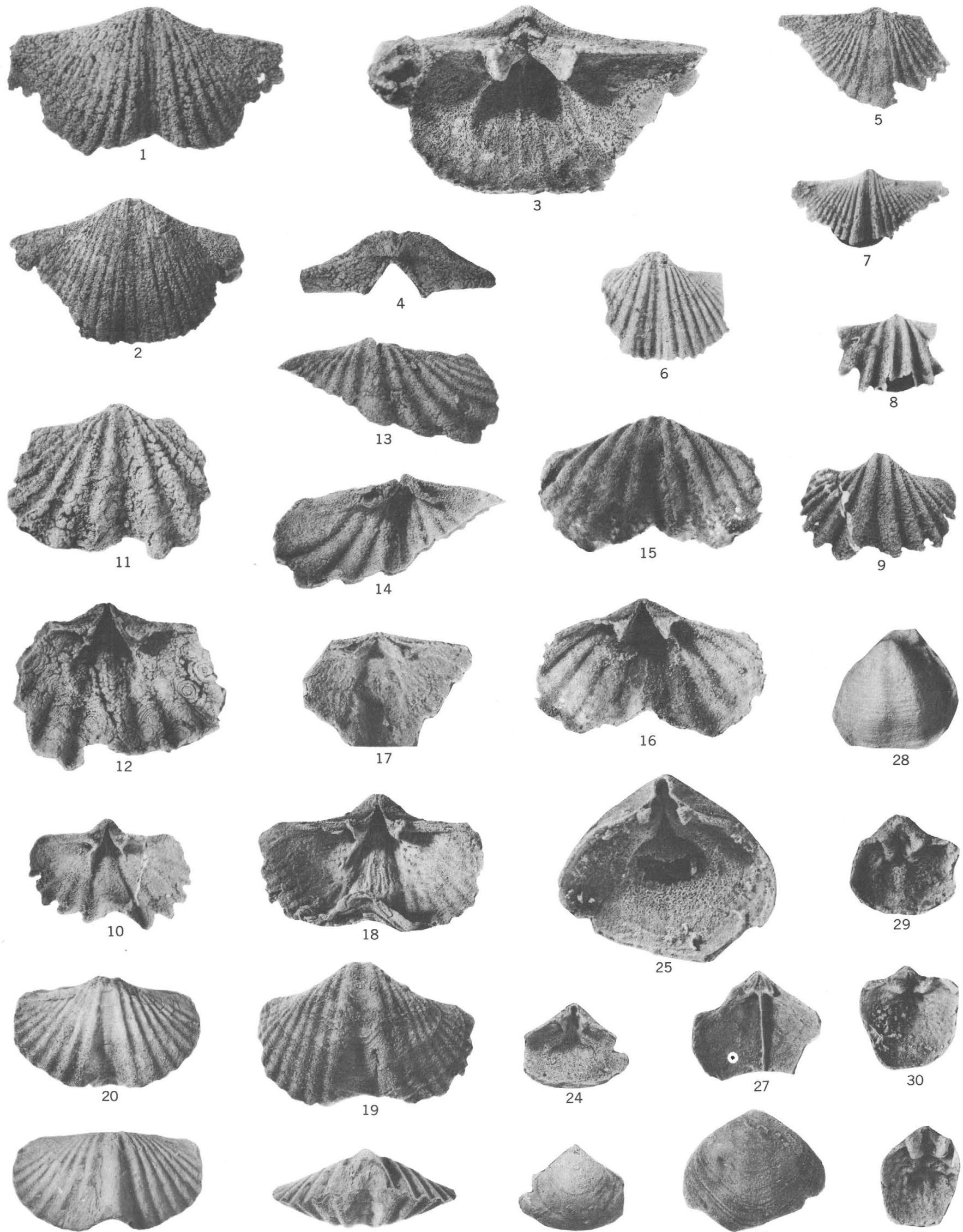

21
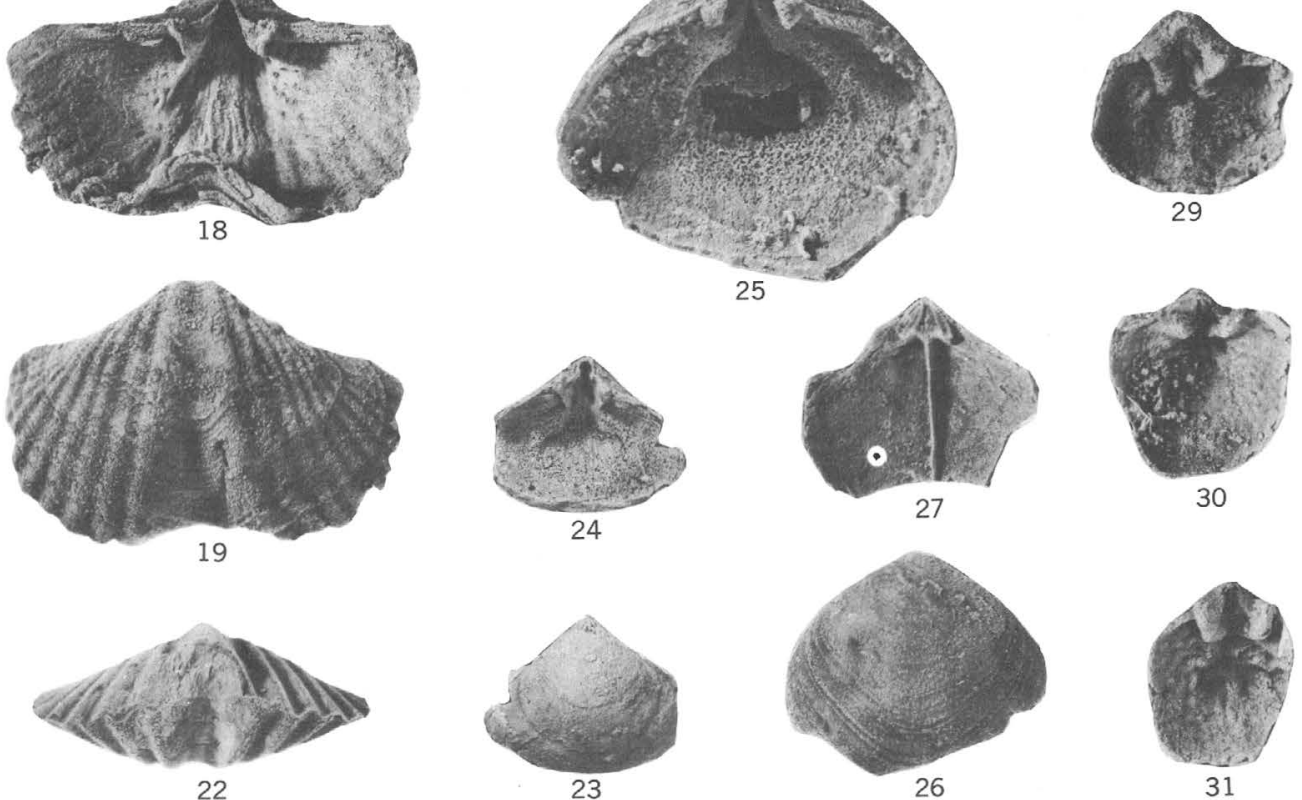

COSTISPIRIFER, ACROSPIRIFER, HOWELLELLA, MERISTELLA, AND AMBOCOELIA 


\section{PLATE 8}

Figures 1-3. Siphonophrentis sp. B

Calice and lateral views $(\times 1)$, and longitudinal thin section $(\times 3)$; USNM 159613. Lower Devonian, Beacon Peak Dolomite Member of the Nevada Formation; southern Sulphur Spring Range. Locality M186.

4. Schuchertella sp.

Brachial valve interior $(\times 2)$; USNM 159614. Lower Devonian, Rabbit Hill Limestone; Dobbin Summit, Monitor Range, Nev. Locality M1311.

5. Leptostrophia sp. cf. L. becki tennesseensis Dunbar.

Brachial valve interior ( $\times$ 2); USNM 159615. Lower Devonian, upper part of Rabbit Hill Limestone; Dobbin Summit, Monitor Range, Nev. Locality M1309.

6-9. Orthostrophia strophomenoides subsp. newberryi n. subsp.

6, 7. Brachial valve exterior and interior ( $\left.\times 1 \frac{1}{2}\right)$; paratype, USNM 159616.

8, 9. Pedicle valve exterior and interior $\left(\times 1 \frac{1}{2}\right)$; paratype, USNM 159617.

Lower Devonian, Rabbit Hill Limestone; Rabbit Hill, Copenhagen Canyon, Nev. Locality M409.

10. Howellella cycloptera subsp. monitorensis $\mathrm{n}$. subsp.

Latex impression of shell bed $(\times 1)$. Lower Devonian, Rabbit Hill Limestone; Dobbin Summit, Monitor Range, Nev. Locality M1311.

11. Rhipidomella cf. $R$. musculosa (Hall).

Ventral valve muscle field $(x 1)$. Lower Devonian, upper part of Rabbit Hill Limestone; Dobbin Summit, Monitor Range, Nev. Locality M1309.

12, 13. Laminated Rabbit Hill chert bed overlain by trilobite coquinite $(\times 1)$.

12. Weather surface of coquinite showing parts of Leonaspis head shields.

13. Edge view showing chert layer overlain by trilobite coquinite.

Lower Devonian, Rabbit Hill Limestone; Rabbit Hill, Copenhagen Canyon, Nev. Locality M409.

14. Weathered surface of platy calcareous siltstone showing "fucoids" $(\times 1)$.

15. Weathered surface of coquinite composed mainly of bryozoans, brachiopods, and crinoidal debris ( $\times 1$ ).

Lower Devonian, Rabbit Hill Limestone; Rabbit Hill, Copenhagen Canyon, Nev. Locality M409.

16, 17. Phacops sp. A

16. Anteroventral edge of cephalon, showing glabella and one eye $\left(\times 1 \frac{1}{2}\right)$.

17. Latex impression, showing dorsal surface of pygidium and several pleura $\left(\times 1 \frac{1}{2}\right)$.

Lower Devonian, Beacon Peak Dolomite Member of the Nevada Formation; southern Sulphur Spring Range, Nev. Locality M197.

18. Weathered surface of a tentaculite $(\times 8)$. Early Devonian, Rabbit Hill Limestone; southeast of Walti Ranch, Simpson Park Range, Nev. Locality M1074. 

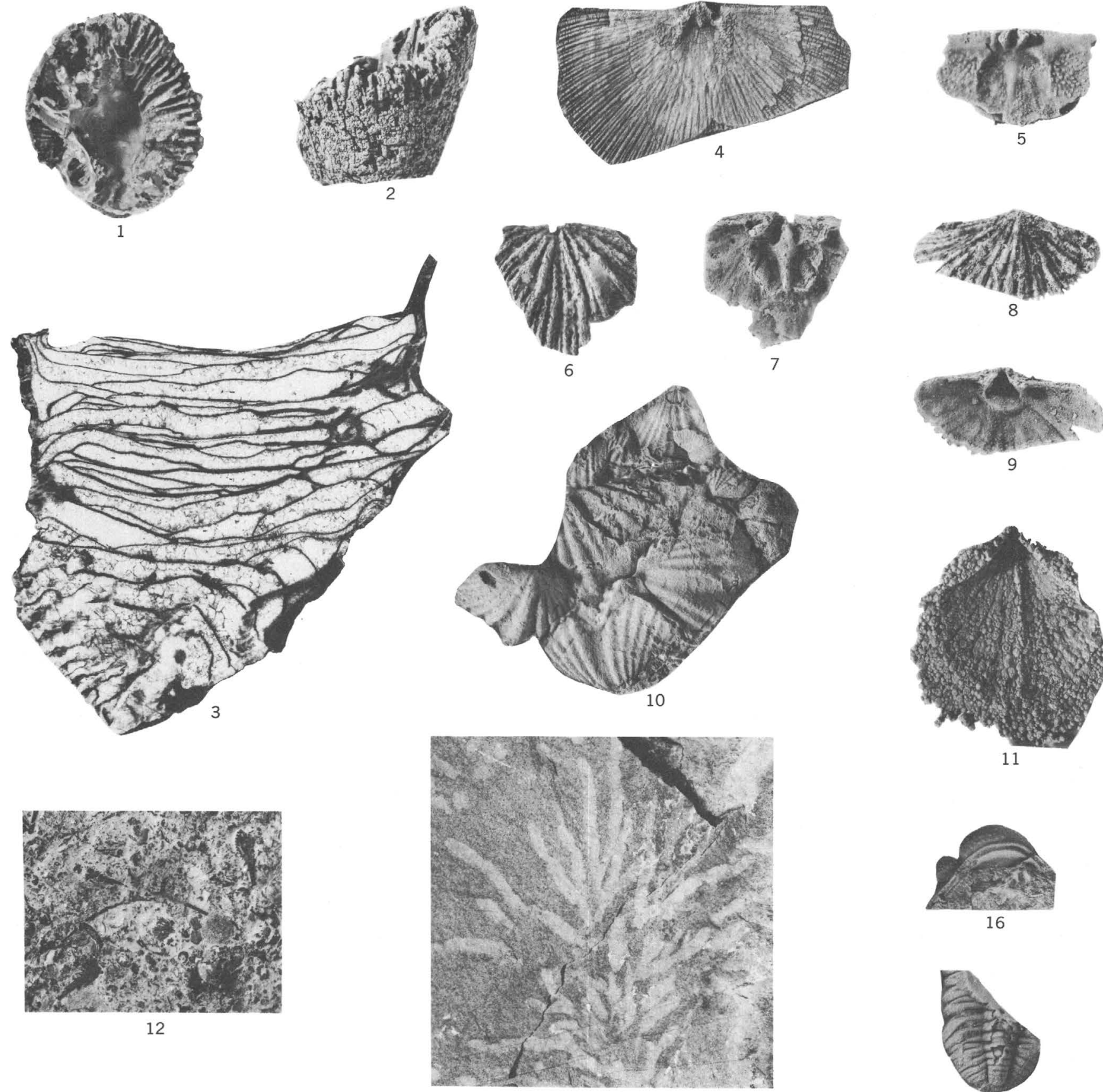

12

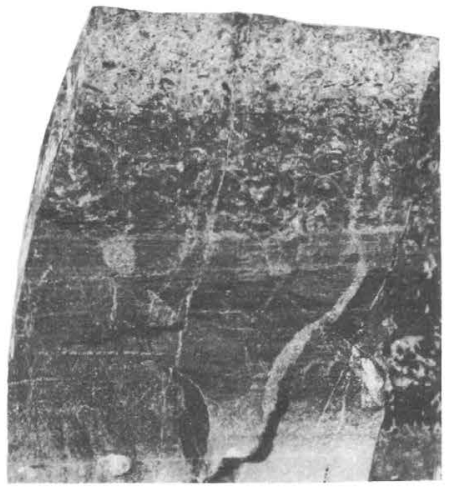

13

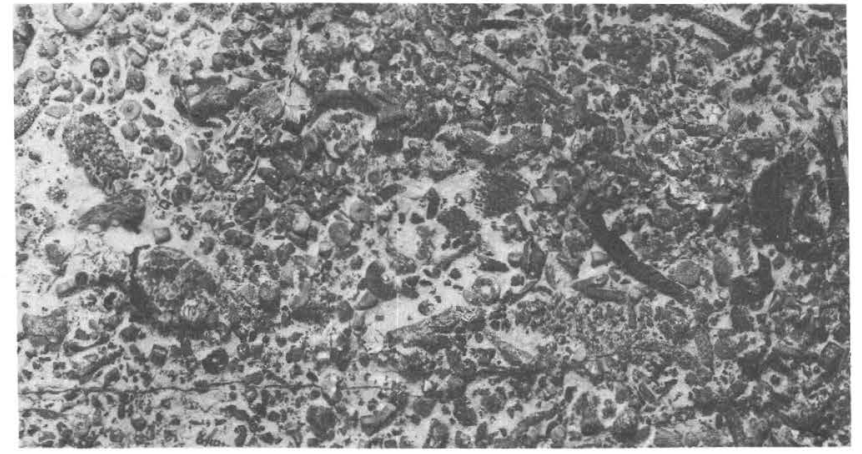

15

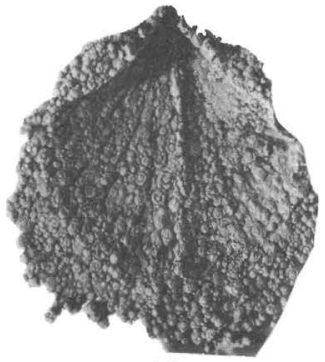

11

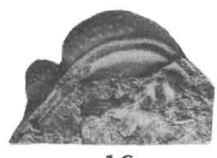

16
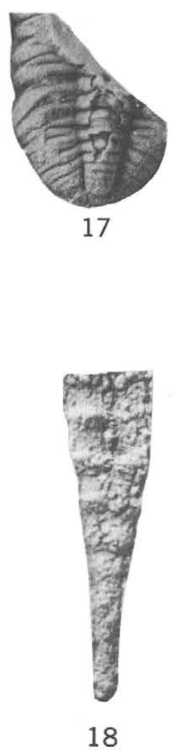

SIPHONOPHRENTIS, SCHUCHERTELLA, LEPTOSTROPHIA, ORTHOSTROPHIA, HOWELLELLA, RHIPIDOMELLA, AND PHACOPS 


\section{PLATE 9}

Figures 1, 2. Billingsastraea sp. m.

Transverse and longitudinal thin sections ( $\times 3$ ); USNM 165350. Early Devonian, Rabbit Hill Limestone, south end of Tuscarora Mountains at Maggie Creek, locality M1400.

3-6. Australophyllum landerensis $\mathrm{n}$. sp.

3, 4. Transverse and longitudinal thin sections $\left(\times 2 \frac{1}{2}\right)$ of holotype, USNM 159353.

5, 6. Transverse and longitudinal thin sections $(\times 2)$ of paratype, USNM 159354.

Early Devonian, Rabbit Hill Limestone, north end of Toquima Range near Petes Summit, locality M1150.

7. Australophyllum sp. v.

Transverse thin section ( $\times$ 2). Mazourka Canyon, northern Inyo Range, Calif.; locality M1093. Upper part of Vaughn Gulch Limestone. From beds of possible Early Devonian age above Silurian coral zone E.

8-13. Australophyllum stevensi n. sp.

8, 9. Transverse thin sections $(\times 2)$ of holotype, USNM 165349.

10-13. Longitudinal thin sections $(\times 2)$ of holotype, USNM 165349.

Mazourka Canyon area, northern Inyo Range, Calif.; locality M1401, east side of Al Rose Canyon. From beds of possible Early Devonian age in upper part of the Sunday Canyon Formation. 

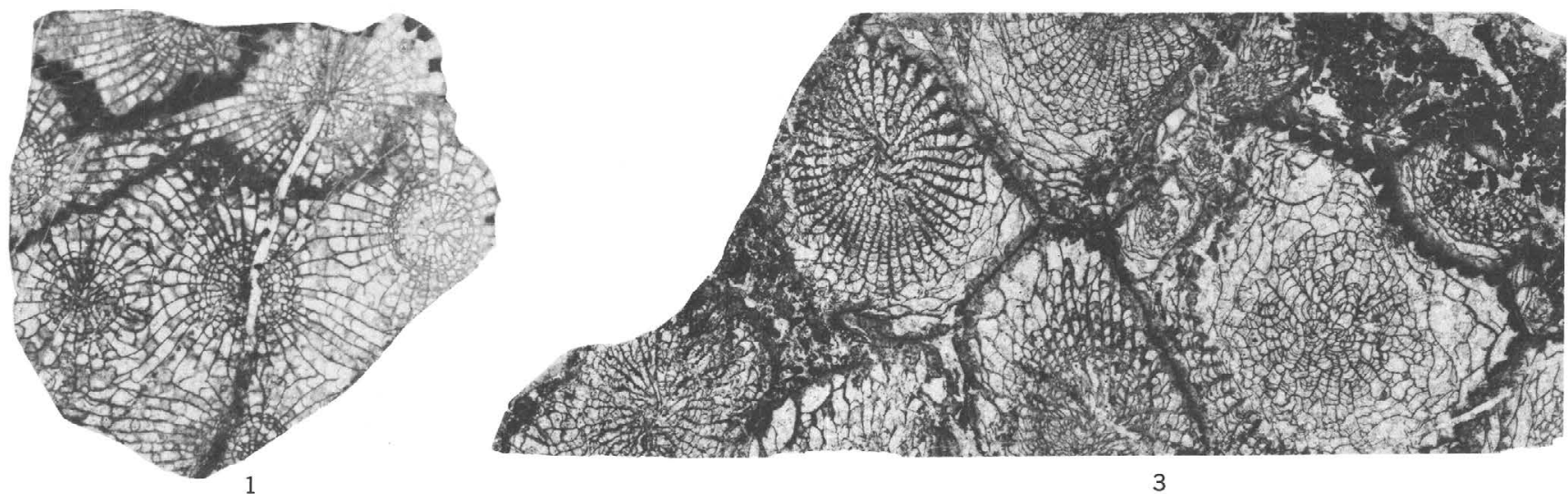

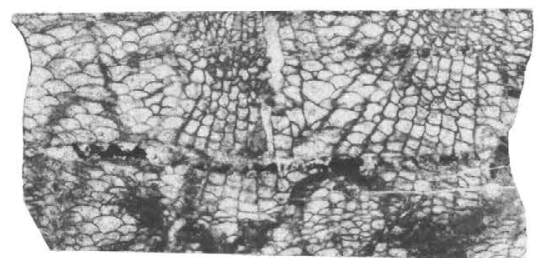

2

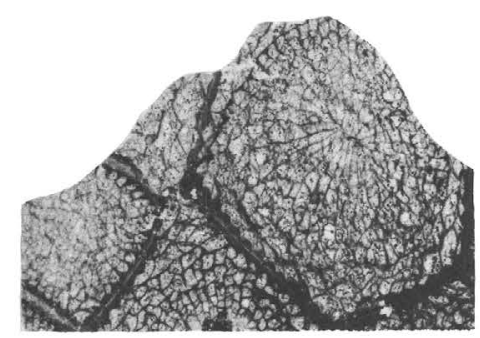

7

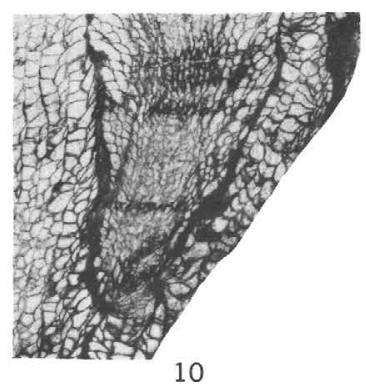

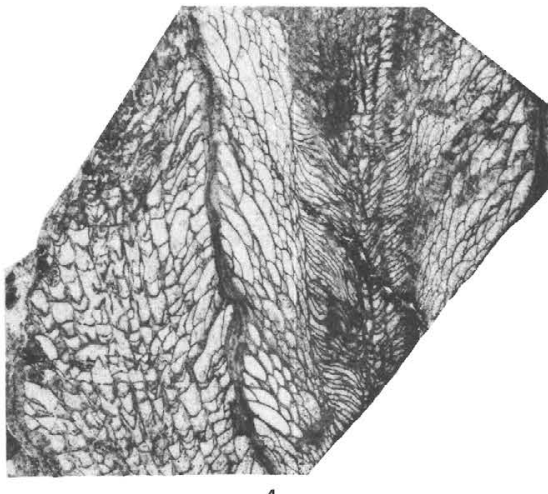

4

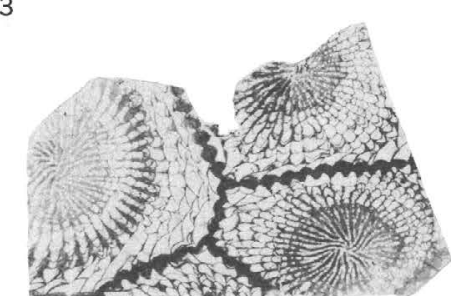

5

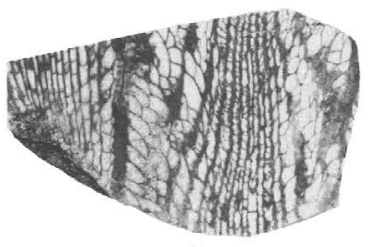

6

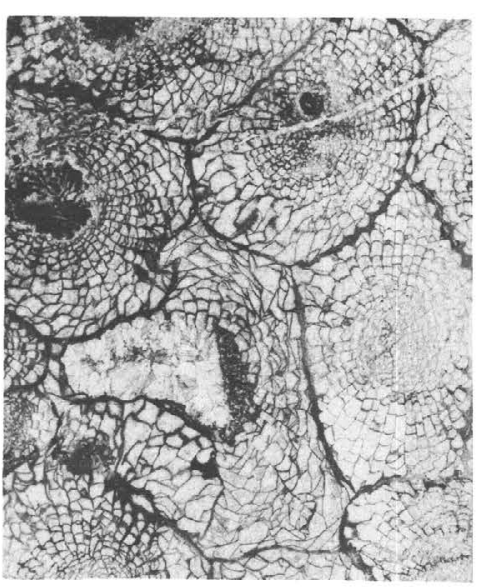

9

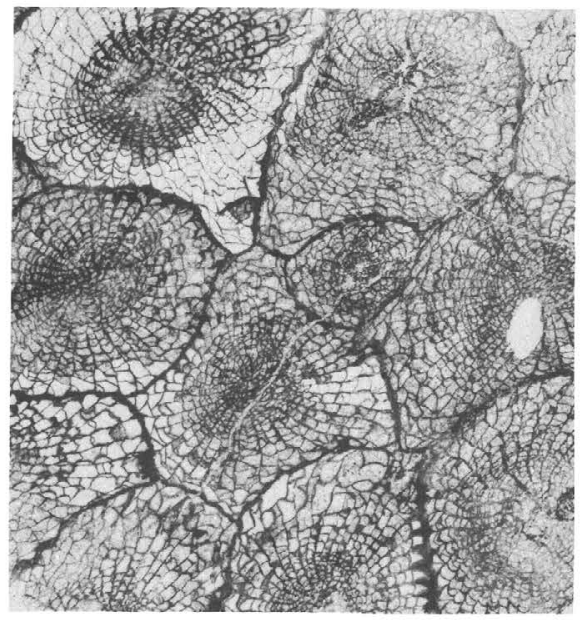

8

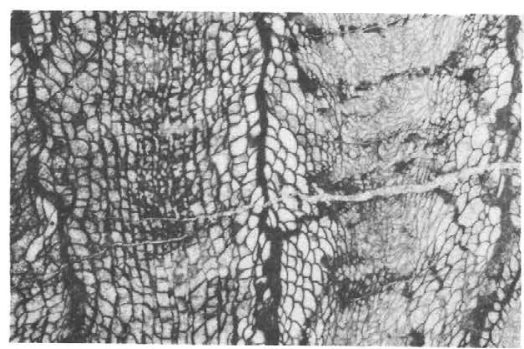

11

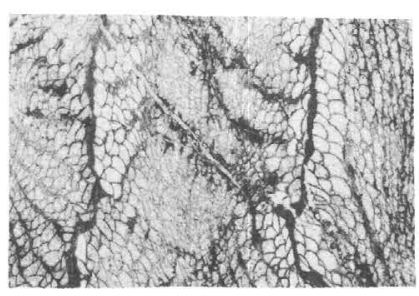

12

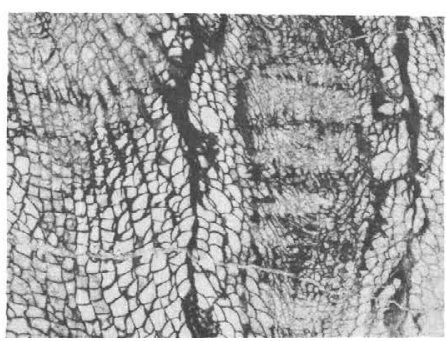

13

BILLINGSASTRAEA AND AUSTRALOPHYLLUM 


\section{PLATE 10}

FIGURES 1-4. Entelophyllum eurekaensis n. sp.

1,2. Transverse and longitudinal thin sections of holotype $(\times 4)$; USNM 159412.

3, 4. Longitudinal and transverse thin sections of paratype $(\times 2)$; USNM 159419.

Late Silurian, upper part of Lone Mountain Dolomite, southern Fish Creek Range, Nev. Locality M1113.

5-11. Entelophyllum engelmanni $\mathrm{n}$. sp.

5. Transverse thin section $(\times 4)$, holotype; USNM 159413.

6, 7. Longitudinal thin section $\left(\times 2, \times 3 \frac{1}{2}\right)$, paratype; USNM 159415 .

8. Longitudinal thin section ( $\times 3$ ), paratype; USNM 159477.

9. Longitudinal thin section $(\times 4)$, paratype; USNM 159414.

10. Longitudinal thin section ( $\times 2$ ), paratype; USNM 159478.

11. Lateral view of paratype (slightly reduced); USNM 159417.

Late Silurian, upper part of Lone Mountain Dolomite; southern Mahogany Hills, Eureka County, Nev. Locality M1112.

12,13. Entelophyllum engelmanni subsp. b.

12. Lateral view of attached corallites $(\times 1)$; shows attached Howellella smithi.

13. Lateral view of attached corallites $\left(\times 1 \frac{1}{2}\right)$.

Late Silurian, upper part of Lone Mountain Dolomite; southern Fish Creek Range, Nev. Locality M1087. 


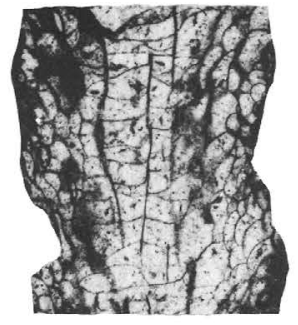

6

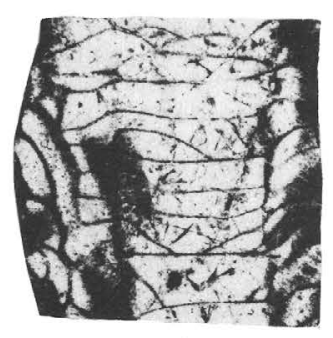

8
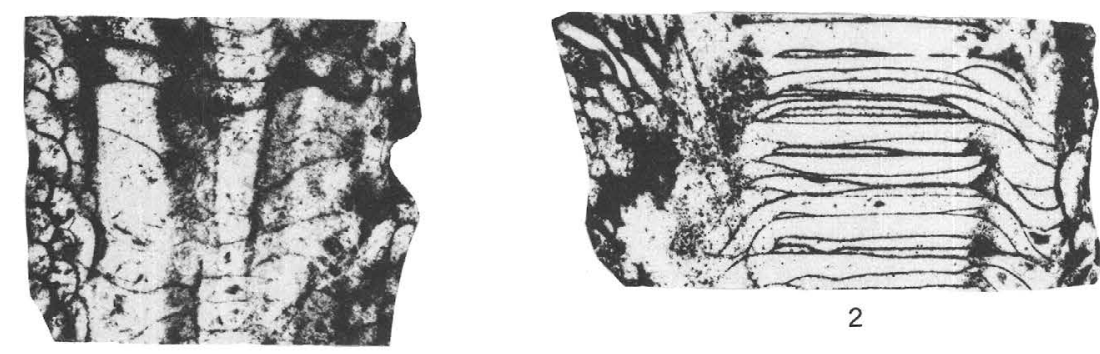
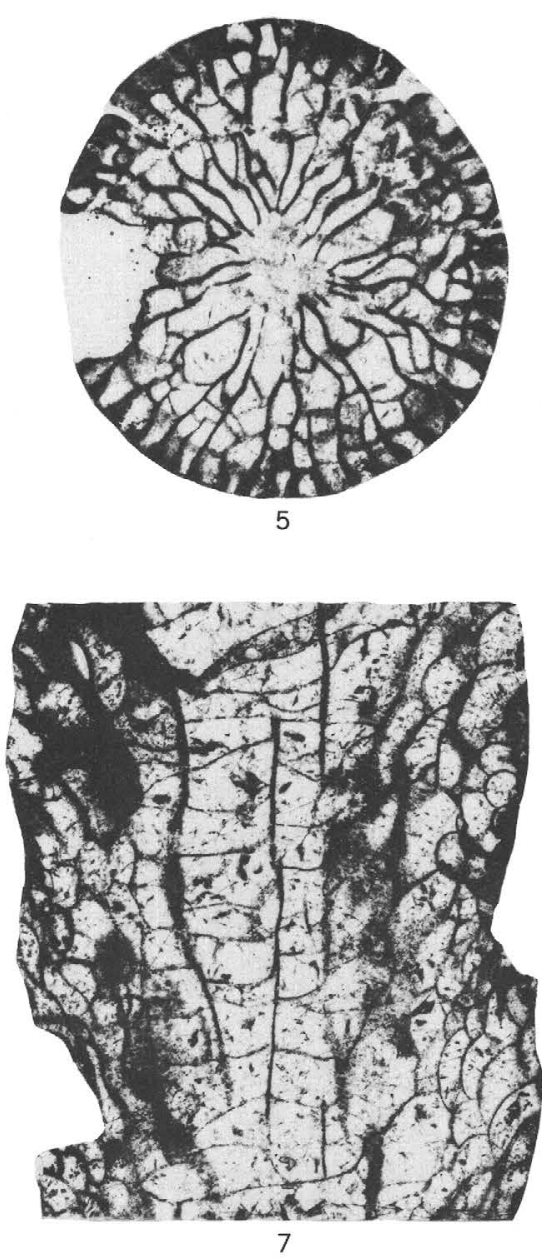
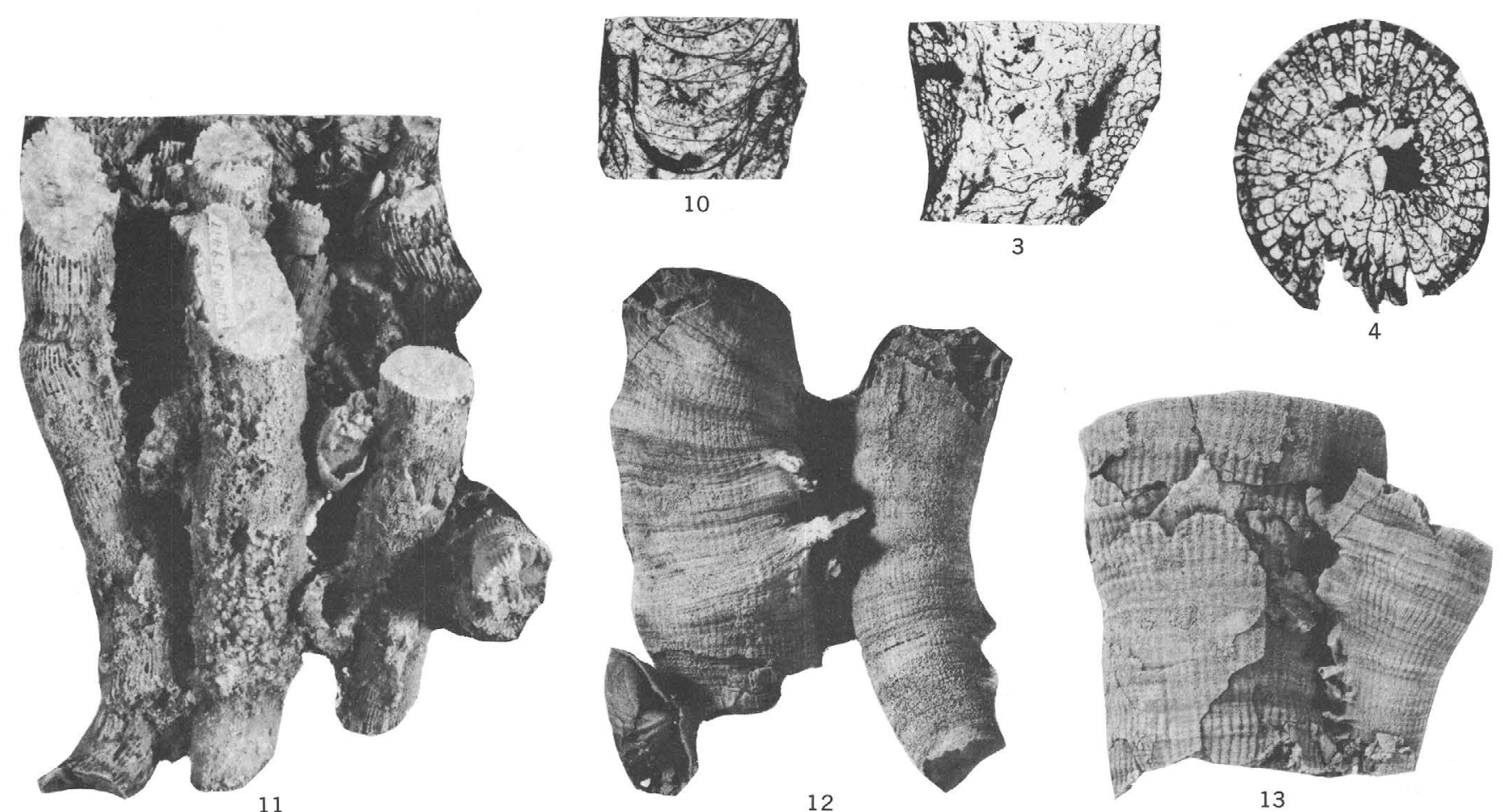

ENTELOPHYLLUM 


\section{PLATE 11}

Figures 1-4. Atrypa sp. f.

1-3. Ventral, dorsal, and lateral views $(\times 2)$; USNM 159479.

4. Dorsal view $(\times 2)$; USNM 159480 .

Late Silurian, upper part of Lone Mountain Dolomite; southern Fish Creek Range, Nev. Locality M1113.

5, 6. Camarotoechia sp. f.

Dorsal and ventral exterior ( $\times$ 2); USNM 159481. Locality M1113. (See figs. 1-4.)

7-9. Camarotoechia pahranagatensis Waite.

Dorsal, ventral, and anterior views (× 2); USNM 159482. Locality M1113. (See figs. 1-4.)

10-13. Camarotoechia sp. b.

10-12. Dorsal, ventral, and anterior views ( $\times$ 2); USNM 159483. Locality M1113. (See figs. 1-4.)

13. Dorsal view $(\times 2)$; USNM 159484. Locality M1113. (See figs. 1-4.)

14, 15. Camarotoechia sp.

Dorsal and anterior views ( $\times$ 2); USNM 159485. Locality M1113. (See figs. 1-4.)

16-23. Salopina sp. $\mathrm{f}$

16, 17. Oblique dorsal and ventral views ( $\times 2)$; USNM 159486.

18, 19. Dorsal valve exterior and interior views $(\times 3)$; USNM 159487.

20. Dorsal valve exterior $(\times 3)$; USNM 159488.

21, 22. Dorsal and ventral exterior $(\times 3)$; USNM 159489.

23. Dorsal exterior $\left(\times 2 \frac{1}{2}\right)$; USNM 159490 .

Late Silurian, upper part of Lone Mountain Dolomite; southern Fish Creek Range, Nev. Locality M1087.

24, 25. Tryplasma sp. f.

Transverse and longitudinal thin sections $(\times 2)$; USNM 159491. Locality M1087. (See figs. 16-23.)

26, 27. Entelophyllum engelmanni subsp. b.

Lateral exterior $\left(\times 1 \frac{1}{2}\right)$ and transverse thin section $\left(\times 1 \frac{1}{2}\right)$; USNM 159492. Locality M1087. (See figs. 16-23.)

28, 29. Pycnostylid coral.

Calice views of same corallite $\left(\times 1, \times 1 \frac{1}{2}\right)$. Silurian, lower part of Lone Mountain Dolomite; southern Sulphur Spring Range, Nev. Locality M1121.

30. Pycnostylus sp.

Longitudinal thin section $(\times 11 / 2)$. Silurian, lower part of Lone Mountain Dolomite, southern Sulphur Spring Range, Nev. Locality M1148.

31. Medium-dark-gray carbonaceous Lone Mountain Dolomite containing silicified Entelophyllum engelmanni subsp. b $(\times 1 / 2)$. Locality M1087. (See figs. 16-23.)

32. Dark-gray carbonaceous Lone Mountain Dolomite containing fragmentary rugose corals, probably Entelophyllum (slightly reduced). Upper part of Lone Mountain Dolomite; east side of Charcoal Gulch, Lone Mountain, Eureka County, Nev. Locality M1122. 
GEOLOGICAL SURVEY
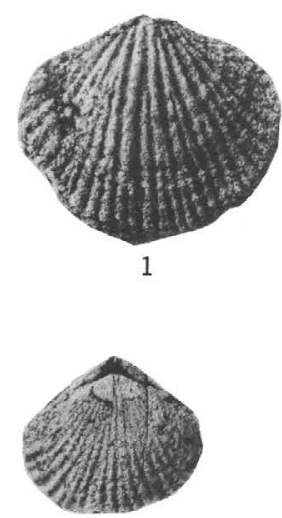

5
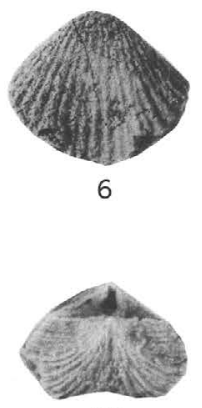

16

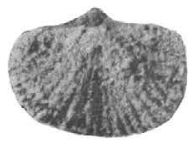

20

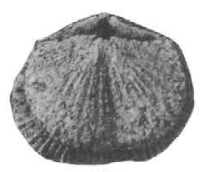

23

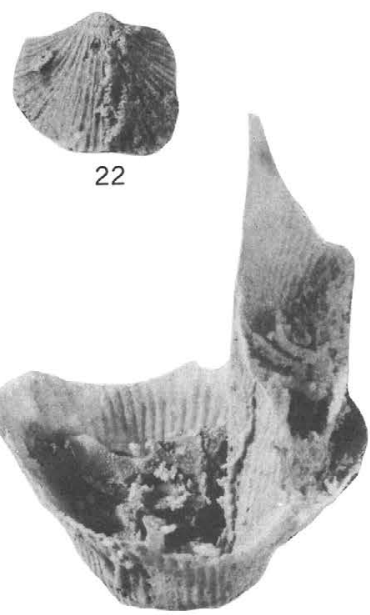

28
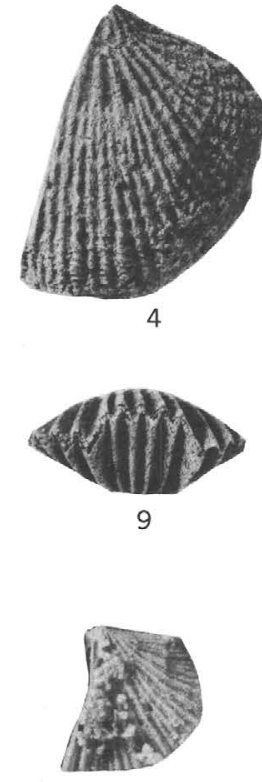

18
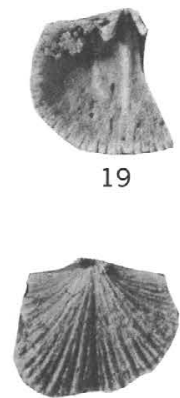

21
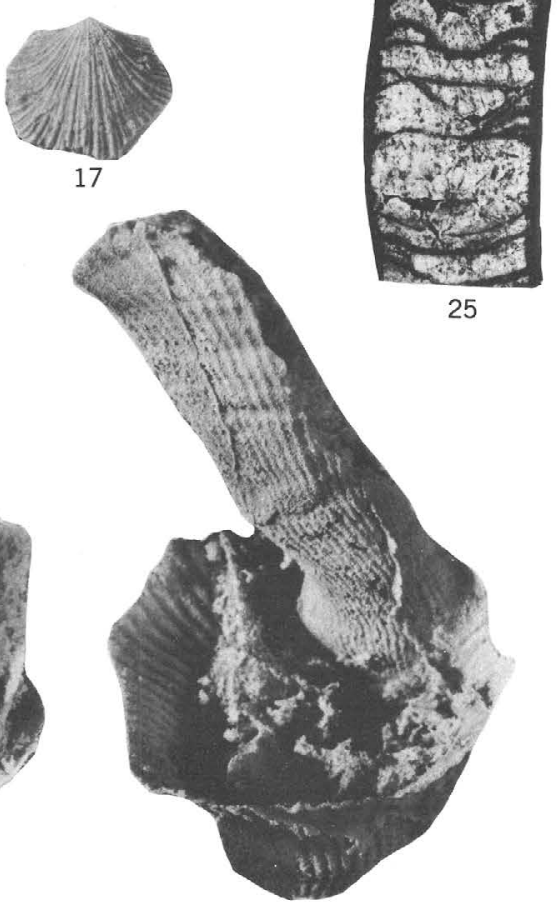

29
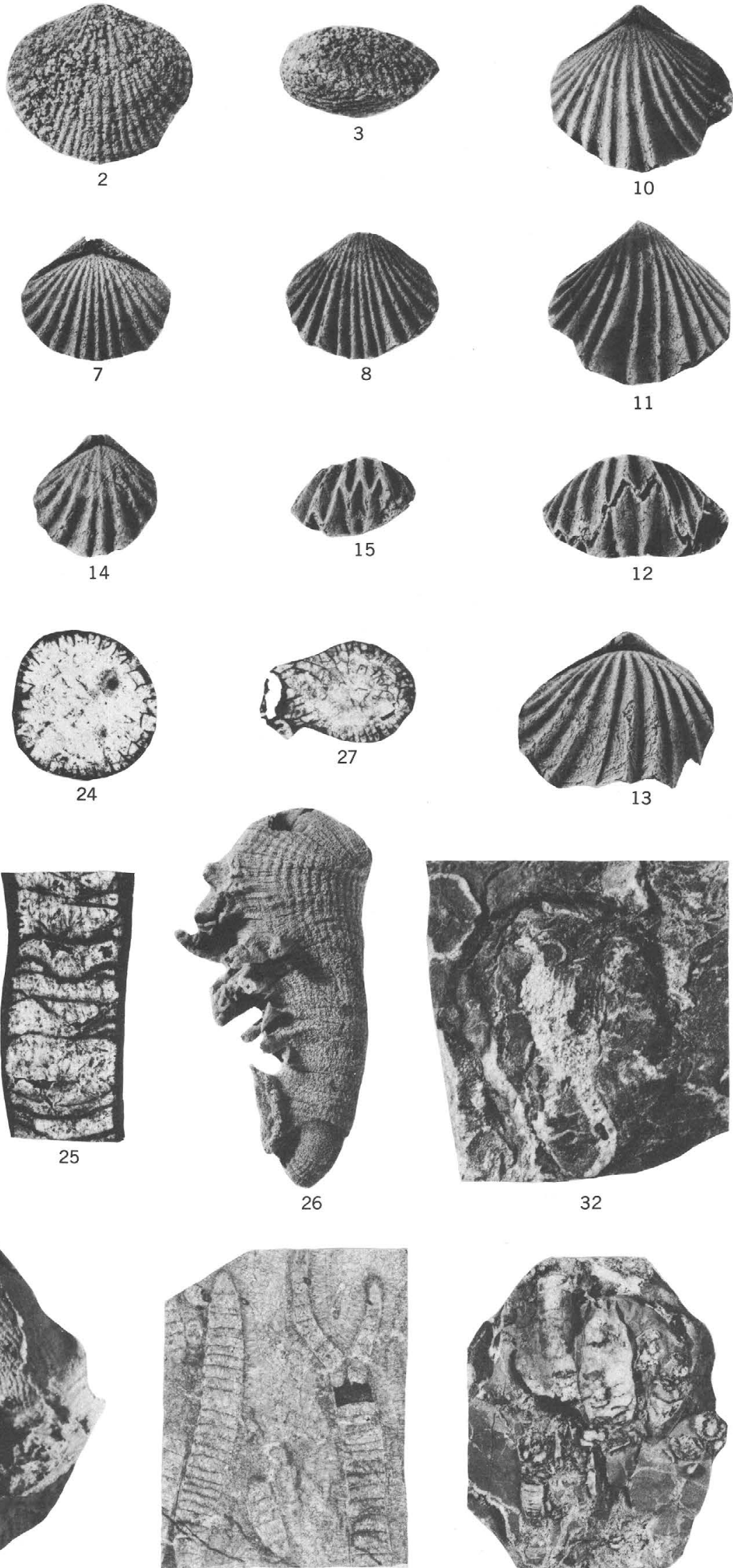

30
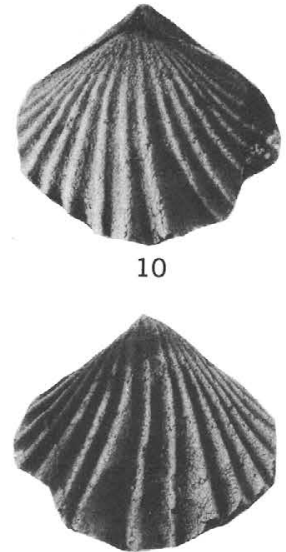

11
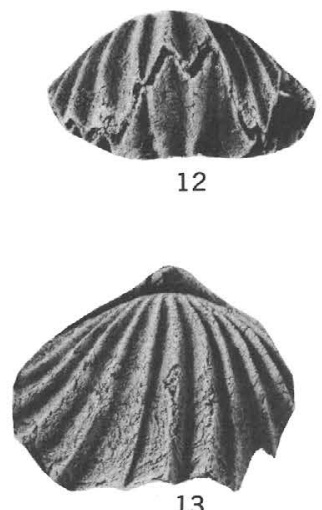

32

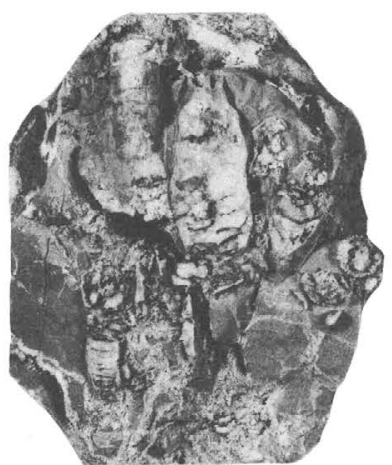

31

ATRYPA, CAMAROTOECHIA, SALOPINA, TRYPLASM A, ENTELOPHYLLUM,

PYCNOSTYLID CORAL AND? PYCNOSTYLUS 
Figures 1-19. Howellella smithi Waite.

\section{PLATE 12}

1-3. Oblique posterior, anterior, and dorsal views $\left(\times 1 \frac{1}{2}\right)$; USNM 159493.

4, 5. Dorsal and ventral views $\left(\times 1 \frac{1}{2}\right)$; USNM 159494.

6, 7. Ventral valve interiors showing dental lamellae $(\times 2)$; USNM 159495.

8. Dorsal valve interior ( $\times 2$ ); USNM 159496.

9,10 . Dorsal and ventral views $\left(\times 1 \frac{1}{2}\right)$; USNM 159497.

11, 12. Dorsal and ventral views $(\times 2)$; USNM 159498.

13. Dorsal exterior $(\times 2)$; USNM 159499.

14. Dorsal exterior $(\times 2)$; USNM 159500 .

15. Dorsal exterior $\left(\times 1 \frac{1}{2}\right)$; USNM 159501.

16. Dorsal exterior ( $\times 4$ ); USNM 159502.

17. Dorsal exterior $(\times 2)$; USN M159503.

18. Dorsal exterior $(\times 2)$; USNM 159504 .

19. Dorsal exterior $(\times 3)$; USNM 159505.

Late Silurian, upper part Lone Mountain Dolomite; southern Fish Creek Range, Nev. Locality M1087.

20-24. Howellella pauciplicata Waite.

20-22. Dorsal, ventral, and posterior views $(\times 2)$; USNM 159506.

23, 24. Dorsal and ventral views $(\times 6)$; USNM 159507.

Late Silurian, upper part Lone Mountain Dolomite; southern Mahogany Hills, Nev. Locality M1112.

25. Medium-dark-gray upper Lone Mountain Dolomite containing abundant silicified Howellella smithi ( $\times 1 / 2)$. Locality M1087. (See figs. 1-19).

26, 27. ?Hyattidina sp.

Dorsal and posterior views ( $\times 2$ ); USNM 159508. Late Silurian, upper part of Lone Mountain Dolomite; southern Fish Creek Range, Nev. Locality M1113.

28, 29. ?Hyattidina sp.

Dorsal and lateral views ( $\times$ 2); USNM 159509. Locality M1113. (See figs. 26, 27.)

30-32. ?Hyattidina sp. f.

Dorsal, anterior, and lateral views (× 3); USNM 159510. Locality M1087. (See figs. 1-19.)

33. ?Hyattidina sp. f.

Ventral view of peeled shell $(\times 4)$ showing part of spiralium with lateral apices. USNM 159511. Locality M1087. (See figs. 1-19.)

34-37. Hindella sp. a.

Dorsal, ventral, lateral, and anterior views $(\times 2)$; USNM 159512. Locality M1087. (See figs. 1-19.) 
GEOLOGICAL SURVEY
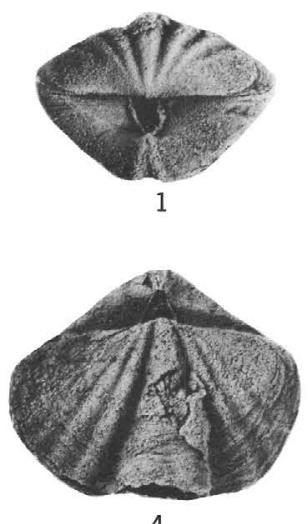

4

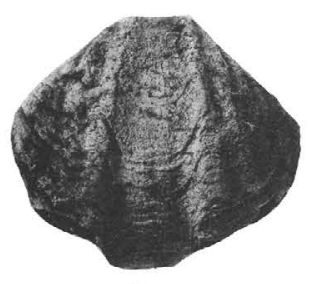

5

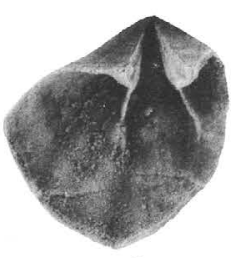

6

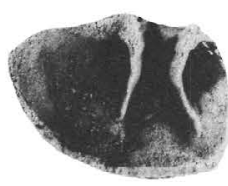

7

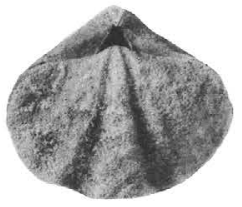

11

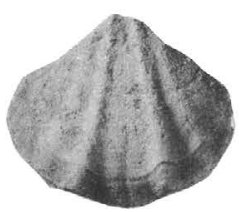

12
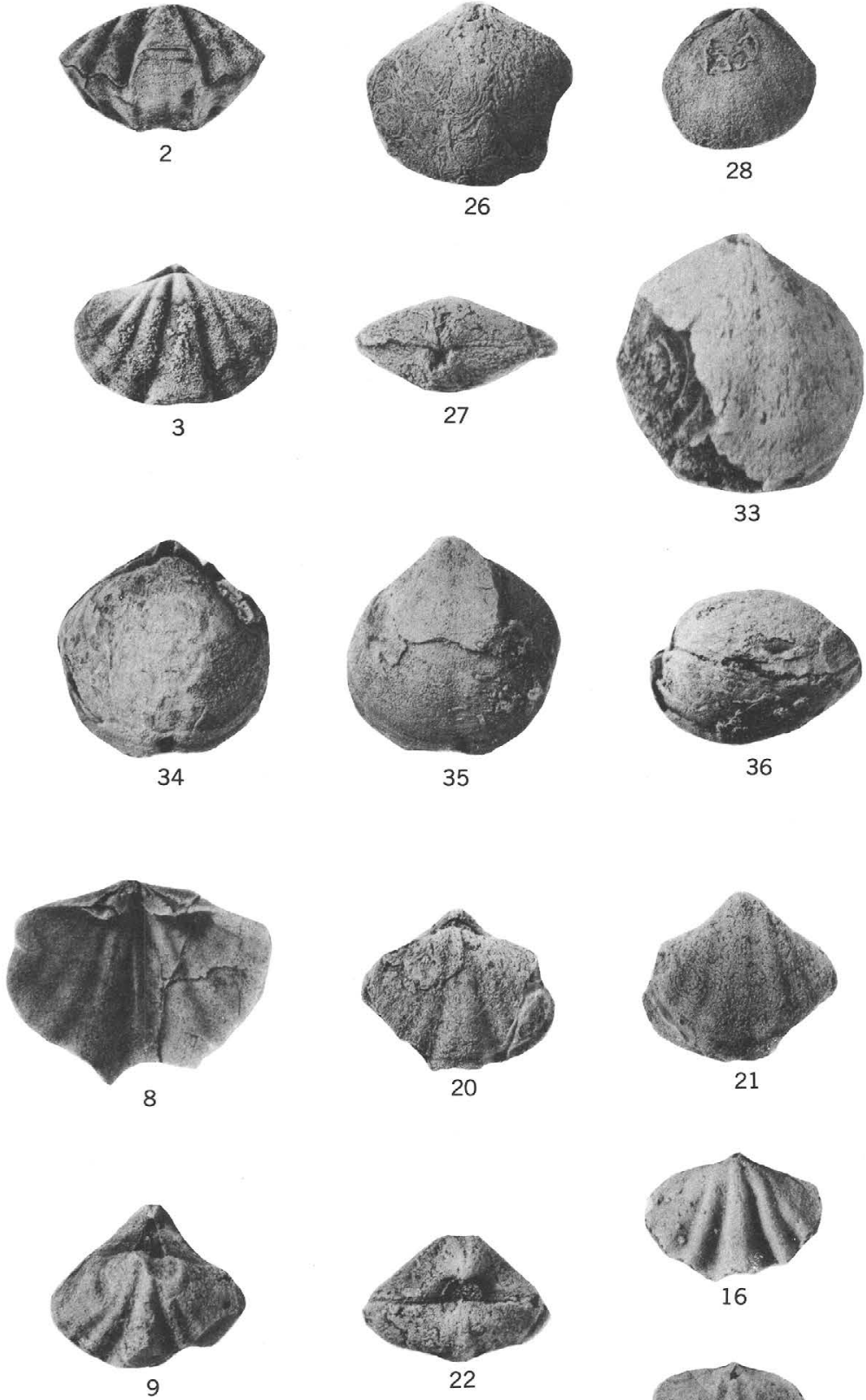

33

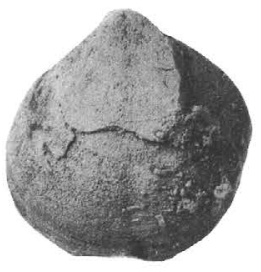

35
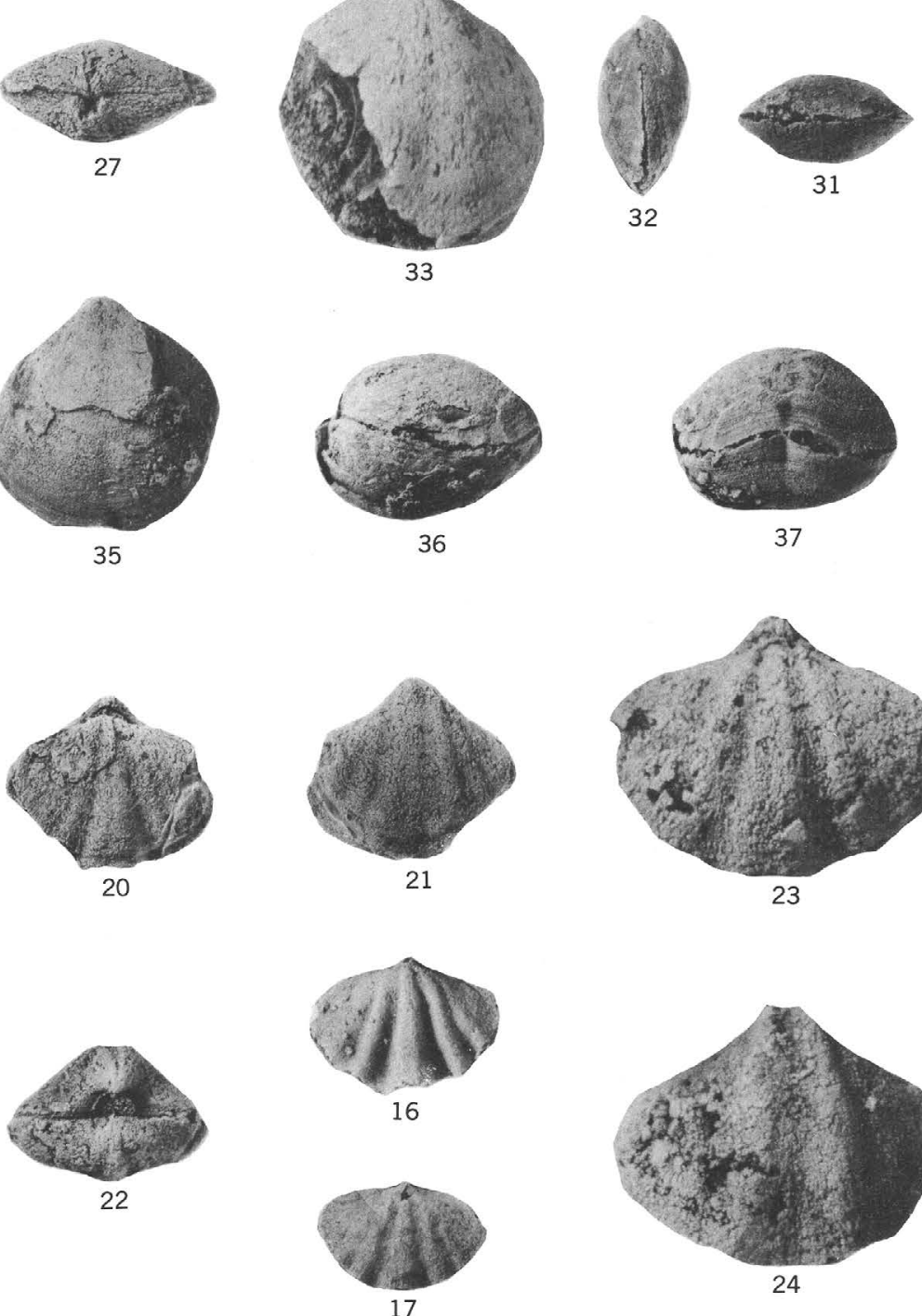

36
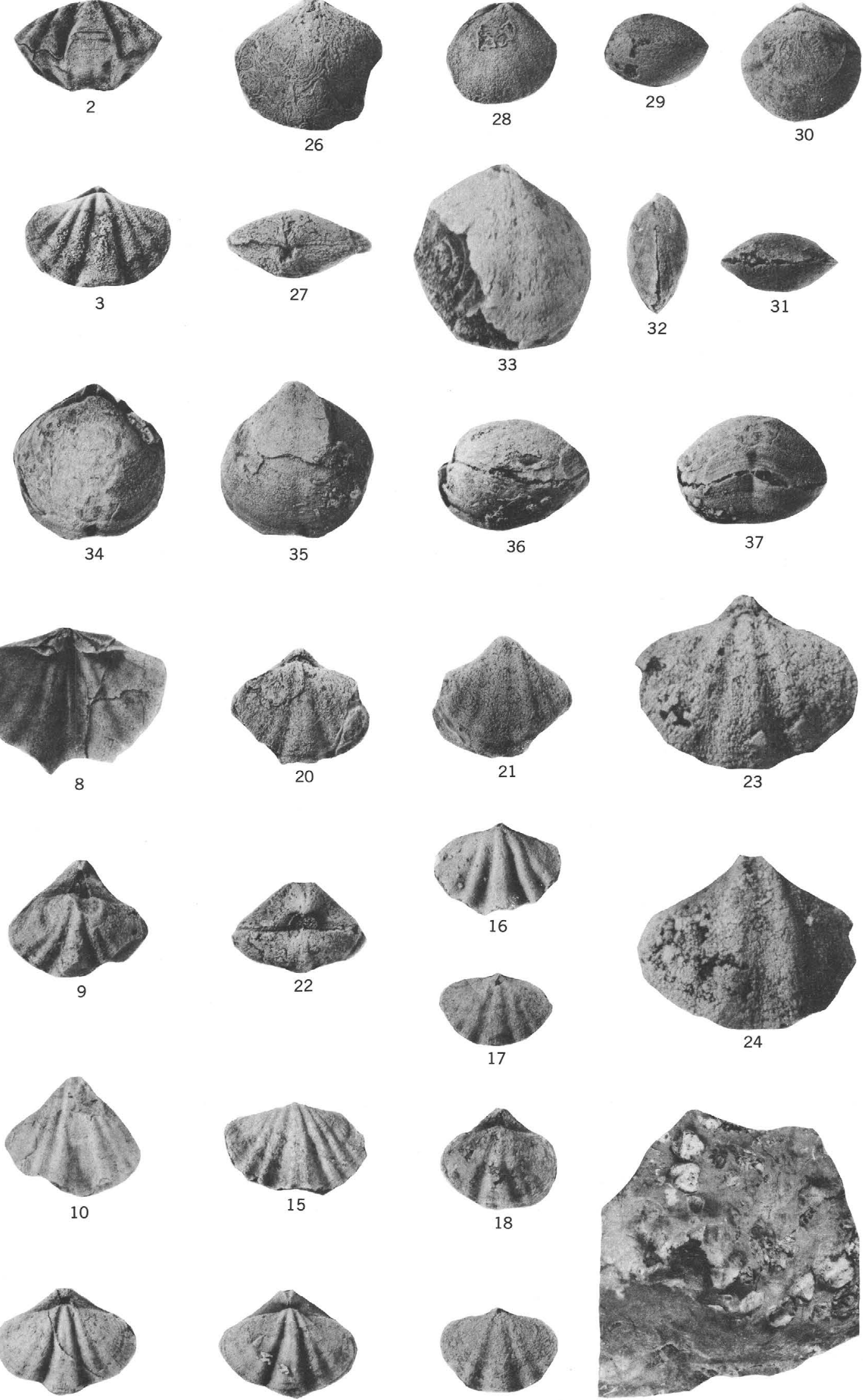

19

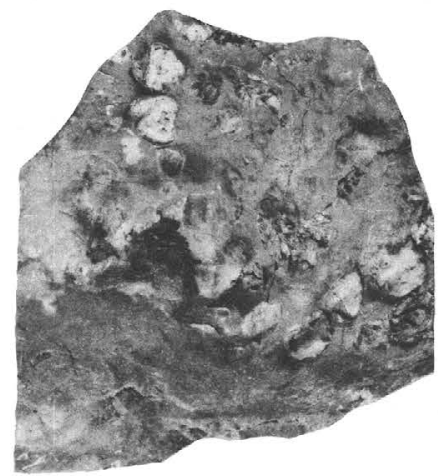

25 


